Supporting Information for

\title{
Tosyloxybenziodoxolone: A Platform for Performing the Umpolung of Alkynes in One-pot Transformations
}

\author{
Julien Borrel and Jerome Waser*
}

Laboratory of Catalysis and Organic Synthesis, Institute of Chemical Sciences and Engineering, Ecole Polytechnique Fédérale de Lausanne, EPFL SB ISIC LCSO, BCH 1402, 1015 Lausanne, Switzerland.

jerome.waser@epfl.ch

(111 pages) 


\section{Table of Contents}

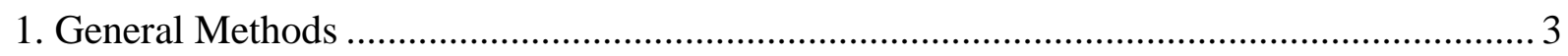

2. Picture of the photochemistry set-up ............................................................................ 5

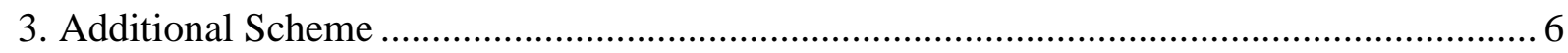

4. Preparation of Hypervalent Iodine Reagents................................................................... 6

5. Synthesis of Potassium Trifluoroborate Salts ................................................................. 9

6. Purification-free Synthesis of EBX Reagents ................................................................. 18

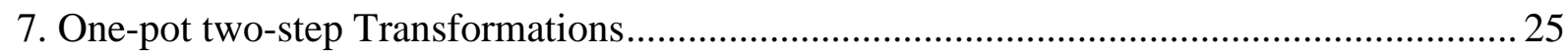

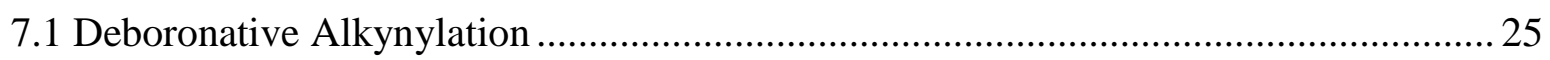

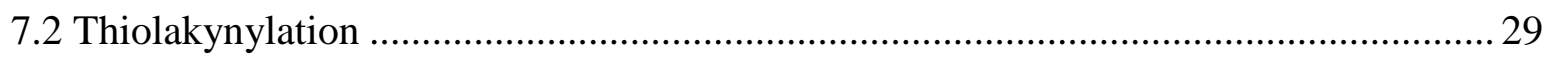

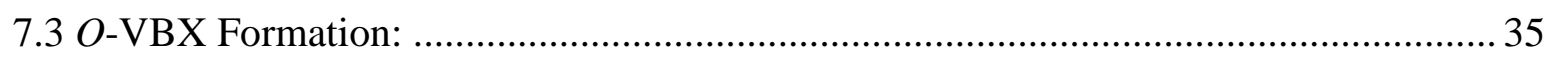

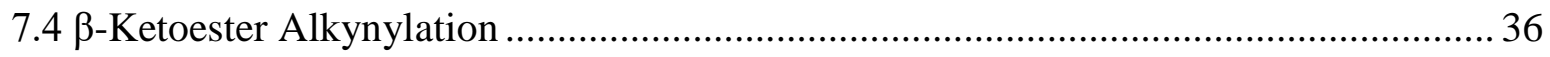

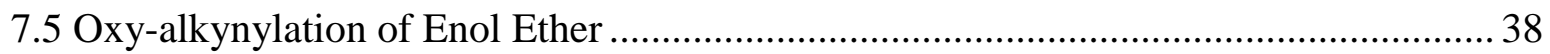

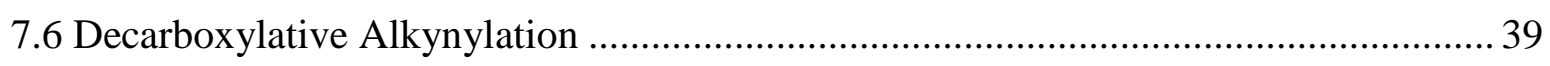

7.7 Synthesis of 1,2-Dithioalkene ……………………................................................. 41

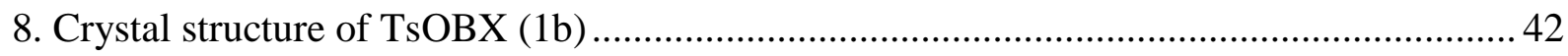

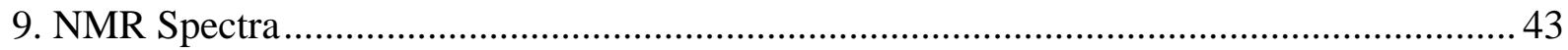




\section{General Methods}

All reactions were carried out under air unless stated otherwise. Reactions requiring heating were carried out using DrySyn heating block. For flash chromatography, distilled technical grade solvents were used. THF, toluene, $\mathrm{Et}_{2} \mathrm{O}$ and $\mathrm{CH}_{2} \mathrm{Cl}_{2}$ were dried by passage over activated alumina under nitrogen atmosphere $\left(\mathrm{H}_{2} \mathrm{O}\right.$ content $<10 \mathrm{ppm}$, Karl-Fischer titration). Solvents were degassed by bubbling with a balloon of argon or by Freeze-Pump-Thaw when mentioned. All chemicals were purchased from Acros, Aldrich, Combi-blocks, Fluka, Fluorochem, Merck, TCI or VWR and used as such unless stated otherwise. Chromatographic purification was performed as flash chromatography using Silicycle silica 40-63 $\mu \mathrm{m}$ (230-400 mesh), using the solvents indicated as eluent with 0.1-0.5 bar pressure or using Biotage Isolera Spektra One with pre-packaged silica cartridges purchased from Buchi, models: Sepacore or GraceResolve (4 g, $12 \mathrm{~g}, 25 \mathrm{~g}, 40 \mathrm{~g}, 80 \mathrm{~g}, 120 \mathrm{~g}$ ). TLC was performed on Merck silica gel 60 F254 TLC glass plates and visualized with UV light and potassium permanganate or $p$-anisaldehyde stain. ${ }^{1} \mathrm{H}-\mathrm{NMR}$ spectra were recorded on a Bruker DPX-400 400 MHz spectrometer in chloroform-d, DMSO$\mathrm{d}_{6}$ or acetone- $\mathrm{d}_{6}$. All signals are reported in ppm using the residual solvent signal as internal reference (chloroform-d: $7.26 \mathrm{ppm}, \mathrm{DMSO}-\mathrm{d}_{6}: 2.50 \mathrm{ppm}$, acetone- $\mathrm{d}_{6}: 2.06 \mathrm{ppm}$ ). The data is being reported as $(\mathrm{s}=$ singlet, $\mathrm{d}=$ doublet, $\mathrm{t}=$ triplet, $\mathrm{q}=$ quadruplet, $\mathrm{qi}=$ quintet, $\mathrm{m}=$ multiplet or unresolved, bs = broad signal, coupling constant(s) in Hz, integration, assignment). ${ }^{13} \mathrm{C}-\mathrm{NMR}$ spectra were recorded with $\left\{{ }^{1} \mathrm{H}\right\}$ decoupling on a Bruker DPX-400 $101 \mathrm{MHz}$ spectrometer in chloroform-d, DMSO- $\mathrm{d}_{6}$ or acetone- $\mathrm{d}_{6}$. All signals are reported in ppm using the residual solvent signal as internal reference (chloroform-d: 77.0 ppm, DMSO- $\mathrm{d}_{6}: 39.5 \mathrm{ppm}$, acetone- $\mathrm{d}_{6}$ : 206.3 and $29.8 \mathrm{ppm}) .{ }^{19} \mathrm{~F}-\mathrm{NMR}$ spectra were recorded with $\left\{{ }^{1} \mathrm{H}\right\}$ decoupling on a Bruker DPX$400376 \mathrm{MHz}$ spectrometer in chloroform-d, DMSO- $\mathrm{d}_{6}$ or acetone- $\mathrm{d}_{6} .{ }^{11} \mathrm{~B}-\mathrm{NMR}$ spectra were recorded on a Bruker DPX-400 128 MHz spectrometer in DMSO- $\mathrm{d}_{6}$ or acetone- $\mathrm{d}_{6}$. High resolution mass spectrometric measurements were performed by the mass spectrometry service of ISIC at the EPFL. Electrospray-ionisation HRMS data were acquired on a Q-Tof Ultima mass spectrometer (Waters) or a Q-Tof 6530 Accurate mass spectrometer (Agilent) operated in the positive ionization mode and fitted with a standard Z-spray ion source equipped with the Lock-Spray interface. Data from the Lock-Spray were used to calculate a correction factor for the mass scale and provide accurate mass information of the analyte. Data were processed using the MassLynx 4.1 software. Atmospheric pressure photo-ionisation (APPI) HRMS measurements were done on a LTQ Orbitrap Elite instrument (Thermofisher) operated in the positive ionization mode. The raw data obtained from the Q-TOF Waters instrument does not take into account the mass of the electron for the ion, the obtained raw data has been corrected by removing (positive ionization) or adding (negative ionization) the mass of the electron $(0.5$ $\mathrm{mDa}$ ). Reactions under blue LEDs irradiation $(460-465 \mathrm{~nm})$ were performed in test tubes (14 $\mathrm{mL}$, soda-lime glass, wall thickness $=0.8 \mathrm{~mm}$ ) which were placed at the center of a crystallization flask. On this flask were attached the blue LEDs (RUBAN LED 5MÈTRES 60LED/M -3528 BLEU - IP65 with Transformateur pour Ruban LED 24W/2A/12V, bought directly on RubanLED.com). The distance between the LEDs and the test tubes was approximatively $3 \mathrm{~cm}$. Long irradiation resulted in temperature increasing up to $35{ }^{\circ} \mathrm{C}$ during 
overnight reactions, a flow of air was maintained in the crystallization flask during reactions. 2b, 2c, 12, 14, 16, 20, 23, 28, 31, 33, 35, 40, 42, 43, 2-ethynyl-1,3,5-trimethylbenzene, ethynyltriisopropylsilane, oct-1-yne, ethynylcyclopropane, 5-chloropent-1-yne, but-3-yn-1-yl 4-methylbenzenesulfonate, 1-ethynyl-3-methoxybenzene, 1-ethynyl-4-fluorobenzene and $\mathrm{N}$ (tert-Butoxycarbonyl)-L-cysteine methyl ester were commercially available. 
2. Picture of the photochemistry set-up

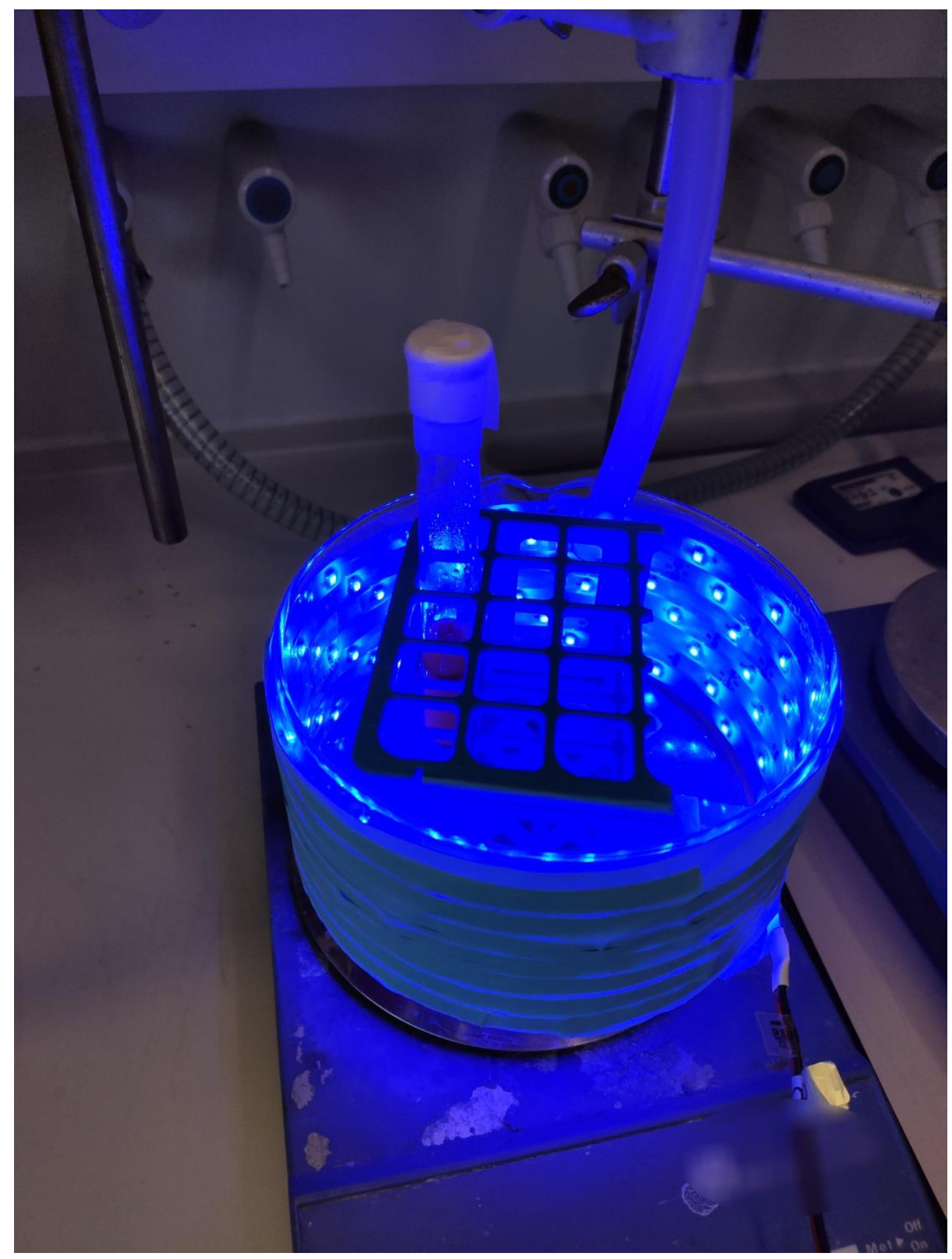




\section{Additional Scheme}
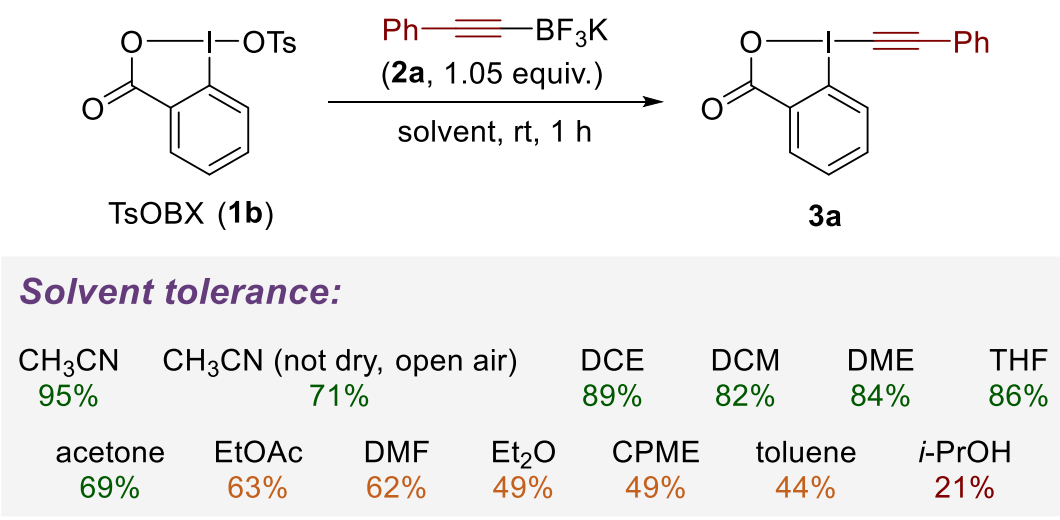

Scheme S1: Solvent tolerance for the formation of EBX (NMR yields are displayed).

\section{Preparation of Hypervalent Iodine Reagents}

\section{1-Hydroxy-1,2-benziodoxol-3-(1H)-one (HOBX, 1a):}<smiles>O=C(O)c1ccccc1I</smiles>

16

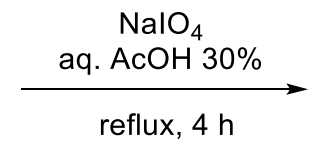

reflux, $4 \mathrm{~h}$<smiles>O=C1OI(O)c2ccccc21</smiles>

1a

Following an adapted version of a reported procedure, ${ }^{1} \mathrm{NaIO}_{4}(18.1 \mathrm{~g}, 84.7 \mathrm{mmol}, 1.05$ equiv) and 2-iodobenzoic acid (16) (20.0 g, $80.6 \mathrm{mmol}, 1.00$ equiv) were suspended in a mixture of $\mathrm{AcOH}(36 \mathrm{~mL})$ and water $(84 \mathrm{~mL})$. The mixture was vigorously stirred and refluxed for $4 \mathrm{~h}$. The reaction mixture was then diluted with cold water $(100 \mathrm{~mL})$ and allowed to cool to room temperature protected from light. The crude product was collected by filtration, washed on the filter with ice water $(3 \times 50 \mathrm{~mL})$ and acetone $(3 \times 50 \mathrm{~mL})$, and air-dried in the dark to give the pure product $1 \mathrm{a}(20.0 \mathrm{~g}, 75.7 \mathrm{mmol}, 94 \%)$ as a white solid. ${ }^{1} \mathrm{H}$ NMR (400 MHz, DMSO-d 6$): \delta$ $8.02(\mathrm{dd}, J=7.7,1.4 \mathrm{~Hz}, 1 \mathrm{H}), 7.97(\mathrm{~m}, 1 \mathrm{H}), 7.85(\mathrm{dd}, J=8.2,0.7 \mathrm{~Hz}, 1 \mathrm{H}), 7.71(\mathrm{td}, J=7.6$, $1.2 \mathrm{~Hz}, 1 \mathrm{H}) ;{ }^{13} \mathrm{C}$ NMR (100 MHz, DMSO-d 6 ): $\delta 167.7,134.5,131.5,131.1,130.4,126.3,120.4$. Spectroscopic data was consistent with the values reported in the literature. ${ }^{1}$

\section{1-(p-Methylbenzenesulfonyloxy)-1,2-benziodoxol-3-(1H)-one (TsOBX, 1b):}

Synthesis of this reagent can be carried out using two different procedures:

\footnotetext{
${ }^{1}$ L. Kraszkiewicz, L. Skulski, Arkivoc 2003, 2003, 120.
} 
<smiles>O=C1OI(O)c2ccccc21</smiles>

$1 \mathrm{a}$

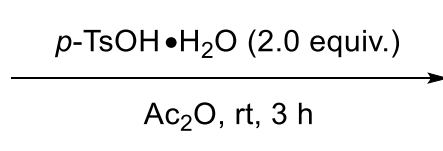

$\mathrm{Ac}_{2} \mathrm{O}, \mathrm{rt}, 3 \mathrm{~h}$<smiles>O=C1OI(O[Na])c2ccccc21</smiles>

$1 b$

Compound $\mathbf{1 b}$ was synthesized following an adapted version of a reported procedure. ${ }^{2} p$ $\mathrm{TsOH} \cdot \mathrm{H}_{2} \mathrm{O}$ (5.71 g, $30.0 \mathrm{mmol}, 2.0$ equiv.) was added portionwise to an oven-dried flask containing a suspension of 1-hydroxy-1,2-benziodoxol-3-(1H)-one (1a) (3.96 g, 15.0 mmol, 1.0 equiv.) in acetic anhydride $(15 \mathrm{~mL})$. After $5 \mathrm{~min}$, a slightly exothermic reaction began and the mixture turned into a clear slightly yellow solution. The reaction was stirred at $\mathrm{rt}$ under $\mathrm{N}_{2}$ for $3 \mathrm{~h}$. During the course of the reaction precipitation of the product as a white solid might occur. Dry $\mathrm{Et}_{2} \mathrm{O}(40 \mathrm{~mL})$ was added and the mixture was cooled to $0{ }^{\circ} \mathrm{C}$ for $10 \mathrm{~min}$. At this point precipitation of the product should have occurred. The solid was filtered and washed with dry $\mathrm{Et}_{2} \mathrm{O}(4 \times 40 \mathrm{~mL})$ then dried in vacuo to afford 1-(p-methylbenzenesulfonyloxy)-1,2benziodoxol-3-(1H)-one (1b) (4.75 g, $11.4 \mathrm{mmol}, 76 \%)$ as a white solid.

Note: The product is slightly hygroscopic, when filtering it using vacuum filtration it is advised to avoid extensive drying on the frit. Just removing the ether is enough to collect it properly and further drying can be carried in vacuo.

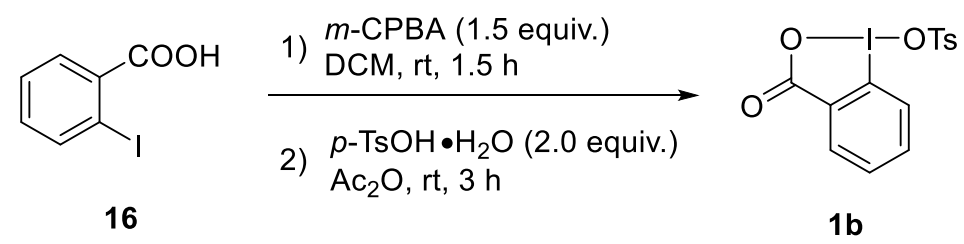

Compound $\mathbf{1 b}$ was synthesized following an adapted version of a reported procedure. ${ }^{3} \mathrm{~m}$-CPBA (1.36 g, $6.0 \mathrm{mmol}, 1.5$ equiv., $77 \%$ purity) was added to an oven-dried flask containing a suspension of 2-iodobenzoic acid (16) (1.0 g, $4.0 \mathrm{mmol}, 1.0$ equiv.) in dry DCM (12 mL). After 5 minutes, precipitation of a white solid occurs. The reaction was stirred at $\mathrm{rt}$ under $\mathrm{N}_{2}$ for 1.5 $h$ then acetic anhydride ( $4 \mathrm{~mL}$ ) was added followed by the portionwise addition of $p-\mathrm{TsOH} \cdot \mathrm{H}_{2} \mathrm{O}$ (1.53 g, $8.06 \mathrm{mmol}, 2.0$ equiv.). After $5 \mathrm{~min}$, a slightly exothermic reaction began and the mixture turned into a clear slightly yellow solution. The reaction was stirred at $\mathrm{rt}$ under $\mathrm{N}_{2}$ for $3 \mathrm{~h}$. The DCM was removed in vacuo, dry $\mathrm{Et}_{2} \mathrm{O}(40 \mathrm{~mL})$ was added and the mixture was cooled to $0{ }^{\circ} \mathrm{C}$ for $10 \mathrm{~min}$. At this point precipitation of the product should have occurred. The solid was filtered and washed with dry $\mathrm{Et}_{2} \mathrm{O}(4 \times 20 \mathrm{~mL})$ then dried in vacuo to afford 1- $(p$ methylbenzenesulfonyloxy)-1,2-benziodoxol-3-(1H)-one (1b) $(0.87 \mathrm{~g}, 2.1 \mathrm{mmol}, 52 \%)$ as a white solid.

\footnotetext{
${ }^{2}$ M. Nappi, C. He, W. G. Whitehurst, B. G. N. Chappell, M. J. Gaunt, Angew. Chem. Int. Ed. 2018, 57, 3178-3182.

${ }^{3}$ Y. Yamamoto, H. Togo, Synlett 2005, 2005, 2486-2488.
} 
${ }^{1} \mathrm{H}$ NMR (400 MHz, DMSO-d 6 ) $\delta 8.01(\mathrm{dd}, J=7.5,1.5 \mathrm{~Hz}, 1 \mathrm{H}), 7.98-7.93(\mathrm{~m}, 1 \mathrm{H}), 7.83(\mathrm{dd}$, $J=8.1,0.9 \mathrm{~Hz}, 1 \mathrm{H}), 7.70(\mathrm{td}, J=7.4,1.0 \mathrm{~Hz}, 1 \mathrm{H}), 7.51-7.46(\mathrm{~m}, 2 \mathrm{H}), 7.15-7.10(\mathrm{~m}, 2 \mathrm{H})$, $2.28\left(\mathrm{~s}, 3 \mathrm{H}, \mathrm{CH}_{3}\right) .{ }^{13} \mathrm{C}$ NMR (101 MHz, DMSO-d 6$) \delta 167.9,145.2,138.1,134.6,131.5,131.2$, 130.5, 128.3, 126.4, 125.6, 120.5, 20.9. HRMS (APCI/QTOF) $\mathrm{m} / \mathrm{z}:[\mathrm{M}+\mathrm{H}]^{+} \mathrm{Calcd}$ for $\mathrm{C}_{14} \mathrm{H}_{12} \mathrm{IO}_{5} \mathrm{~S}^{+} 418.9445$; Found 418.9437. Spectroscopic data was consistent with the values reported in the literature. ${ }^{2}$

Note: We observed a slow solubilization of $\mathbf{1 b}$ if dry DMSO is used. We think water present in DMSO help the solubilization and that when dry DMSO is used the solubilization happen after a couple of minutes $(\sim 5 \mathrm{~min})$ due to the progressive absorption of the water present in the air by the solvent.

\section{1-Acetoxy-1,2-benziodoxol-3-(1H)-one (1c):}<smiles>O=C1OI(O)c2ccccc21</smiles>

$1 \mathrm{a}$

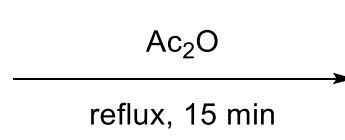

reflux, $15 \mathrm{~min}$<smiles>CC(=O)OI1OC(=O)c2ccccc21</smiles>

$1 \mathrm{c}$

Following a reported procedure, ${ }^{4}$ a suspension of $\mathbf{1 a}(5.0 \mathrm{~g}, 19 \mathrm{mmol}, 1$ equiv. $)$ in acetic anhydride $(19 \mathrm{~mL})$ was refluxed until total dissolution $(\sim 15 \mathrm{~min})$. The resulting clears solution was allowed to cool to room temperature and then cooled to $5{ }^{\circ} \mathrm{C}$ in the fridge. The white crystals were filtered, washed with pentane $(3 \times 30 \mathrm{~mL})$ and dried under reduced pressure to afford 1-Acetoxy-1,2-benziodoxol-3-(1H)-one (1c) $(5.0 \mathrm{~g}, 16 \mathrm{mmol}, 86 \%)$ as a white solid. ${ }^{1} \mathrm{H}$ $\operatorname{NMR}\left(400 \mathrm{MHz}, \mathrm{CDCl}_{3}\right) \delta 8.26(\mathrm{dd}, J=7.6,1.6 \mathrm{~Hz}, 1 \mathrm{H}), 8.01(\mathrm{dd}, J=8.1,0.9 \mathrm{~Hz}, 1 \mathrm{H}), 7.96$ $-7.90(\mathrm{~m}, 1 \mathrm{H}), 7.72$ (td, $J=7.4,1.0 \mathrm{~Hz}, 1 \mathrm{H}), 2.26$ (s, 3H). Spectroscopic data was consistent with the values reported in the literature. ${ }^{5}$

1-Chloro-1,2-benziodoxol-3-(1H)-one (1d):

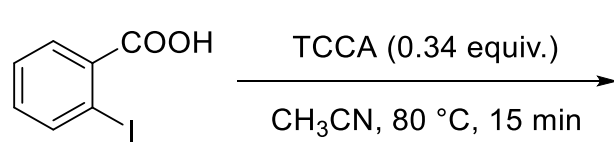

16<smiles>O=C1OI(Cl)c2ccccc21</smiles>

$1 d$

Following a reported procedure, ${ }^{6}$ an oven-dried 2-neck round bottom flask charged with 16 (500 mg, $2.02 \mathrm{mmol}, 1.00$ equiv.) and equipped with a condenser was evacuated and backfilled with $\mathrm{N}_{2}(3 \mathrm{x})$. Dry acetonitrile (4 mL) was added and the mixture was heated to $80{ }^{\circ} \mathrm{C}$ (become

\footnotetext{
${ }^{4}$ E. Grenet, J. Waser, Org. Lett. 2018, 20, 1473-1476.

${ }^{5}$ S. Bertho, R. Rey-Rodriguez, C. Colas, P. Retailleau, I. Gillaizeau, Chem. - Eur. J. 2017, 23, 17674-17677.

${ }^{6}$ D. L. Poeira, J. Macara, H. Faustino, J. A. S. Coelho, P. M. P. Gois, M. M. B. Marques, Eur. J. Org. Chem. 2019, 2019, 2695-2701.
} 
a clear solution). A hot $\left(35-40^{\circ} \mathrm{C}\right)$ solution of trichloroisocyanuric acid (159 $\mathrm{mg}, 0.685 \mathrm{mmol}$, 0.34 equiv. $)$ in dry acetonitrile $(1 \mathrm{~mL})$ was added dropwise over $5 \mathrm{~min}$. The reaction was stirred at $80{ }^{\circ} \mathrm{C}$ for 10 min then immediately filtered over a hot plug of silica and eluted with $15 \mathrm{~mL}$ of hot acetonitrile. The filtrate was concentrated in vacuo to afford 1-chloro-1,2-benziodoxol3-(1H)-one (1d) (386 mg, $1.37 \mathrm{mmol}, 68 \%$ ) as a yellow solid. ${ }^{1} \mathrm{H} \mathrm{NMR}\left(400 \mathrm{MHz}, \mathrm{CDCl}_{3}\right) \delta$ $8.27(\mathrm{dd}, J=7.5,1.6 \mathrm{~Hz}), 8.22(\mathrm{dd}, J=8.4,0.8 \mathrm{~Hz}), 8.04-7.95(\mathrm{~m}, 1 \mathrm{H}), 7.80(\mathrm{td}, J=7.4,0.8$ $\mathrm{Hz}, 1 \mathrm{H}) .{ }^{13} \mathrm{C} \mathrm{NMR}\left(101 \mathrm{MHz}, \mathrm{CDCl}_{3}\right) \delta 167.2,136.8,133.6,132.0,128.8,127.0,117.2$. Spectroscopic data was consistent with the values reported in the literature. ${ }^{6}$

\section{Synthesis of Potassium Trifluoroborate Salts}

General note: It is known that carbons linked to the boron atom are difficult to be observed by ${ }^{13} \mathrm{C}$ NMR due to a broadening of the signal caused by the quadrupole moment of ${ }^{11} \mathrm{~B}$ nuclei. This implies that the carbon directly linked to the boron (in alkyl- $\mathrm{BF}_{3} \mathrm{~K}$ ) or the two carbons of the alkyne (in alkynyl-BF $3 \mathrm{~K}$ ) are too broad to be properly visible. ${ }^{7}$ Therefore, they are not listed in the characterization data.

\section{General procedure A:}

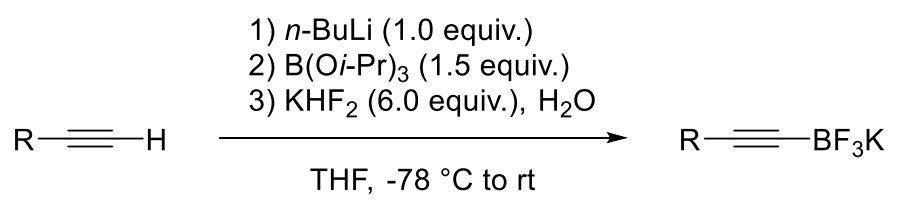

Adapted version of a reported procedure. ${ }^{8}$ An oven-dried round-bottom flask (PFA), charged with alkyne (1.0 equiv.) if solid, was evacuated and backfilled with $\mathrm{N}_{2}(3 \mathrm{x})$. Then, alkyne (if liquid) and dry THF $(0.3 \mathrm{M})$ were added. The mixture was cooled to $-78{ }^{\circ} \mathrm{C}$ and a solution of $n$-BuLi (2.5 M, 1.0 equiv.) in hexane was added dropwise under $\mathrm{N}_{2}$. The reaction was stirred at $-78{ }^{\circ} \mathrm{C}$ for $1 \mathrm{~h}$ and $\mathrm{B}(\mathrm{O} i \text { - } \mathrm{Pr})_{3}(1.5$ equiv.) was added quickly. The reaction was stirred $10 \mathrm{~min}$ at $-78{ }^{\circ} \mathrm{C}$ then $2 \mathrm{~h}$ at $\mathrm{rt}$. The mixture was cooled to $0{ }^{\circ} \mathrm{C}$ and a saturated solution of $\mathrm{KHF}_{2}(6.0$ equiv.) in water ( $40 \%$ of THF volume + additional $40 \%$ to rinse the remaining solid) was added. The reaction was stirred at $\mathrm{rt}$ open to air for $2 \mathrm{~h}$ then concentrated in vacuo. The wet solid obtained was further dried by co-evaporation with acetone. To the dry solid was added acetone $(\sim 50 \mathrm{~mL})$ and the resulting mixture was placed on a rotary evaporator and rotated rapidly at atmospheric pressure with the bath set at $45^{\circ} \mathrm{C}$ for 15 minutes. The flask was removed and the mixture carefully filtered taking care to leave the insoluble material in the reaction flask. Acetone was once again added and the process (heating for $15 \mathrm{~min}$ then collection of the liquid) was repeated 2 more times. The combined acetone filtrates were concentrated in vacuo to approximately $1 / 3$ of the initial volume. $\mathrm{Et}_{2} \mathrm{O}(\sim 60 \mathrm{~mL})$ was added causing a white solid to

\footnotetext{
${ }^{7}$ R. A. Oliveira, R. O. Silva, G. A. Molander, P. H. Menezes, Magn. Reson. Chem. 2009, 47, 873-878.

${ }^{8}$ D. A. Mundal, K. E. Lutz, R. J. Thomson, J. Am. Chem. Soc. 2012, 134, 5782-5785.
} 
precipitate. The mixture was cooled to $0{ }^{\circ} \mathrm{C}$ for $10 \mathrm{~min}$ then filtered. The solid obtained was washed with $\mathrm{Et}_{2} \mathrm{O}$ and dried in vacuo to afford the desired potassium alkynyltrifluoroborate.

Note: This purification procedure usually affords the pure desired product. If it is not the case a more classical recrystallization from acetone followed by precipitation with $\mathrm{Et}_{2} \mathrm{O}$ can be performed.

Potassium trifluoro(phenylethynyl)borate (2a):

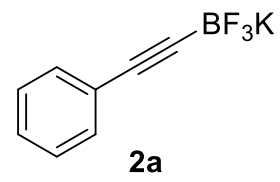

Synthesized following general procedure A starting from phenylacetylene $(1.53 \mathrm{~g}, 1.65 \mathrm{~mL}$, $15.0 \mathrm{mmol})$. Potassium trifluoro(phenylethynyl)borate (2a) $(2.60 \mathrm{~g}, 12.5 \mathrm{mmol}, 83 \%)$ was obtained as a white solid. ${ }^{1} \mathrm{H}$ NMR (400 MHz, acetone-d $\left.\mathrm{d}_{6}\right) \delta 7.35-7.29(\mathrm{~m}, 2 \mathrm{H}), 7.27-7.17$ $(\mathrm{m}, 3 \mathrm{H}) .{ }^{13} \mathrm{C}$ NMR $(101 \mathrm{MHz}$, acetone-d 6$) \delta 132.1,128.8,127.4,127.2 .{ }^{19} \mathrm{~F}$ NMR $(376 \mathrm{MHz}$, acetone-d6) $\delta$-135.0. Spectroscopic data was consistent with the values reported in the literature. $^{9}$

Potassium trifluoro(mesitylethynyl)borate (17):<smiles>Cc1cc(C)c(C#C[Br+]Br)c([N+](=O)[O-])c1</smiles>

Synthesized following general procedure A starting from 2-ethynyl-1,3,5-trimethylbenzene (0.950 g, $1.03 \mathrm{~mL}, 6.3 \mathrm{mmol})$. Potassium trifluoro(mesitylethynyl)borate (17) (1.23 g, 4.94 mmol, 78\%) was obtained as a white solid. Mp (Dec.): $233{ }^{\circ} \mathrm{C} ;{ }^{1} \mathrm{H}$ NMR (400 MHz, acetone$\left.\mathrm{d}_{6}\right) \delta 6.79(\mathrm{~s}, 2 \mathrm{H}), 2.34(\mathrm{~s}, 6 \mathrm{H}), 2.20(\mathrm{~s}, 3 \mathrm{H}) .{ }^{13} \mathrm{C} \mathrm{NMR}\left(101 \mathrm{MHz}\right.$, acetone- $\left.\mathrm{d}_{6}\right) \delta 140.0,135.9$, 127.9, 124.0, 21.3, 21.2. ${ }^{19} \mathrm{~F}$ NMR (377 MHz, acetone-d 6$) \delta-134.3 .{ }^{11} \mathrm{~B}$ NMR (128 MHz, acetone-d $)) \delta-1.0\left(\mathrm{q}, J=37.3 \mathrm{~Hz}\right.$ ). HRMS (APPI/LTQ-Orbitrap) $\mathrm{m} / \mathrm{z}$ : [M-K] ${ }^{-}$Calcd for $\mathrm{C}_{11} \mathrm{H}_{11} \mathrm{BF}_{3}^{-}$211.0911; Found 211.0901.

Potassium trifluoro((triisopropylsilyl)ethynyl)borate (18):

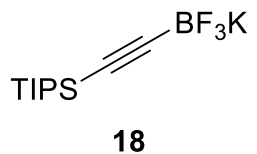

${ }^{9}$ G. A. Molander, B. W. Katona, F. Machrouhi, J. Org. Chem. 2002, 67, 8416-8423. 
Synthesized following general procedure A starting from ethynyltriisopropylsilane $(1.37 \mathrm{~g}$, $1.68 \mathrm{~mL}, 7.5 \mathrm{mmol})$. Potassium trifluoro((triisopropylsilyl)ethynyl)borate (18) (1.75 g, 6.08 mmol, $81 \%)$ was obtained as a white solid. ${ }^{1} \mathrm{H}$ NMR (400 MHz, acetone- $\left.\mathrm{d}_{6}\right) \delta 1.10-1.04(\mathrm{~m}$, $21 \mathrm{H}) .{ }^{13} \mathrm{C}$ NMR $\left(101 \mathrm{MHz}\right.$, acetone- $\left.\mathrm{d}_{6}\right) \delta 19.1,12.2 .{ }^{19} \mathrm{~F}$ NMR (376 MHz, acetone- $\left.\mathrm{d}_{6}\right) \delta-135.1$. Spectroscopic data was consistent with the values reported in the literature. ${ }^{10}$

\section{Potassium trifluoro(oct-1-yn-1-yl)borate (19):}

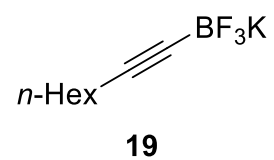

Synthesized following general procedure A starting from oct-1-yne $(0.83 \mathrm{~g}, 1.1 \mathrm{~mL}, 7.5$ mmol). Potassium trifluoro(oct-1-yn-1-yl)borate (19) (1.32 g, $6.10 \mathrm{mmol}, 81 \%)$ was obtained as a white solid. ${ }^{1} \mathrm{H}$ NMR (400 MHz, DMSO-d 6$) \delta 2.00-1.93(\mathrm{~m}, 2 \mathrm{H}), 1.39-1.18(\mathrm{~m}, 8 \mathrm{H})$, $0.86(\mathrm{t}, J=7.0 \mathrm{~Hz}, 3 \mathrm{H}) .{ }^{13} \mathrm{C} \mathrm{NMR}\left(101 \mathrm{MHz}, \mathrm{DMSO}_{-} \mathrm{d}_{6}\right) \delta 31.0,29.0,28.1,22.1,18.9,14.0$. ${ }^{19} \mathrm{~F}$ NMR (376 MHz, DMSO-d 6 ) $\delta$-131.0. Spectroscopic data was consistent with the values reported in the literature. ${ }^{11}$

Potassium trifluoro(prop-1-yn-1-yl)borate (21):

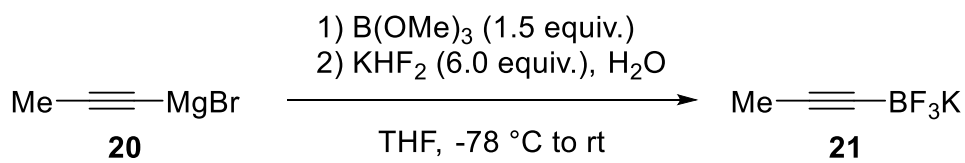

Compound 20 was synthesized following an adapted version of a reported procedure. ${ }^{12}$ An oven-dried round-bottom flask (PFA) was evacuated and backfilled with $\mathrm{N}_{2}(3 \mathrm{x})$. Then, a solution of 1-propynylmagnesium bromide (20) $(15 \mathrm{~mL}, 7.5 \mathrm{mmol}, 0.5 \mathrm{M}, 1.0$ equiv.) in THF and dry THF $(15 \mathrm{~mL})$ were added. The solution was cooled to $-78{ }^{\circ} \mathrm{C}$ and $\mathrm{B}(\mathrm{OMe})_{3}(1.25 \mathrm{~mL}$, $11.3 \mathrm{mmol}, 1.5$ equiv.) was added quickly under $\mathrm{N}_{2}$. The reaction was stirred $1 \mathrm{~h}$ at $-78^{\circ} \mathrm{C}$ then $1.5 \mathrm{~h}$ at $-20{ }^{\circ} \mathrm{C}$. A saturated solution of $\mathrm{KHF}_{2}$ (3.5 g, $45 \mathrm{mmol}, 6.0$ equiv.) in water $(10 \mathrm{~mL}+$ additional $10 \mathrm{~mL}$ to rinse the remaining solid) was added. The reaction was stirred at $\mathrm{rt}$ open air for $2 \mathrm{~h}$ then concentrated in vacuo. The wet solid obtained was further dried by coevaporation with acetone. To the dry solid was added acetone $(\sim 30 \mathrm{~mL})$ and the resulting mixture was placed on a rotary evaporator and rotated rapidly at atmospheric pressure with the bath set at $45^{\circ} \mathrm{C}$ for 15 minutes. The flask was removed and the mixture carefully filtered taking care to leave the insoluble material in the reaction flask. Acetone was once again added and the

\footnotetext{
${ }^{10}$ K. Stout, T. P. J. Peters, M. F. J. Mabesoone, F. L. L. Visschers, E. M. Meijer, J.-R. Klop, J. van den Berg, P. B. White, A. E. Rowan, R. J. M. Nolte, J. A. A. W. Elemans, Eur. J. Org. Chem. 2020, 2020, 7087-7100.

${ }^{11}$ K. Jouvin, F. Couty, G. Evano, Org. Lett. 2010, 12, 3272-3275.

12 P. B. Brady, E. M. Carreira, Org. Lett. 2015, 17, 3350-3353.
} 
process (heating for $15 \mathrm{~min}$ then collection of the liquid) was repeated 2 more times. The combined acetone filtrates were concentrated in vacuo to approximately $1 / 3$ of the initial volume. $\mathrm{Et}_{2} \mathrm{O}(\sim 30 \mathrm{~mL})$ was added causing a white solid to precipitate. The mixture was cooled to $0{ }^{\circ} \mathrm{C}$ for $10 \mathrm{~min}$ then filtered. The solid obtained was washed with $\mathrm{Et}_{2} \mathrm{O}$ and dried in vacuo to afford potassium trifluoro(prop-1-yn-1-yl)borate (21) $(0.95 \mathrm{~g}, 6.5 \mathrm{mmol}, 87 \%)$ as a white solid. Mp (Dec.): $238{ }^{\circ} \mathrm{C} ;{ }^{1} \mathrm{H}$ NMR (400 MHz, acetone-d 6$) \delta 1.64-1.58(\mathrm{~m}, 3 \mathrm{H}) .{ }^{13} \mathrm{C} \mathrm{NMR}$ $\left(101 \mathrm{MHz}\right.$, acetone- $\left.\mathrm{d}_{6}\right) \delta 4.0 .{ }^{19} \mathrm{~F} \mathrm{NMR}\left(376 \mathrm{MHz}\right.$, acetone- $\left.\mathrm{d}_{6}\right) \delta-134.7(\mathrm{dd}, J=76.0,37.4 \mathrm{~Hz})$. ${ }^{11} \mathrm{~B}$ NMR (128 MHz, acetone-d 6$) \delta-1.7(\mathrm{q}, J=38.2 \mathrm{~Hz}$ ). HRMS (ESI/QTOF) $\mathrm{m} / \mathrm{z}$ : [M$\mathrm{K}]^{-}$Calcd for $\mathrm{C}_{3} \mathrm{H}_{3} \mathrm{BF}_{3}^{-}$107.0285; Found 107.0285.

\section{Potassium (cyclopropylethynyl)trifluoroborate (22):}

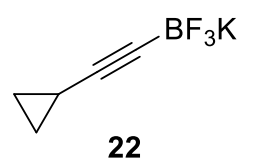

Synthesized following general procedure A starting from ethynylcyclopropane $(0.50 \mathrm{~g}, 0.64$ $\mathrm{mL}, 7.5 \mathrm{mmol}$ ). Potassium (cyclopropylethynyl)trifluoroborate (22) (0.86 g, $5.0 \mathrm{mmol}, 67 \%$ ) was obtained as a white solid. Mp (Dec.): $250{ }^{\circ} \mathrm{C} ;{ }^{1} \mathrm{H}$ NMR (400 MHz, DMSO-d 6 ) $\delta 1.12-$ $1.01(\mathrm{~m}, 1 \mathrm{H}), 0.61-0.54(\mathrm{~m}, 2 \mathrm{H}), 0.42-0.36(\mathrm{~m}, 2 \mathrm{H}) .{ }^{13} \mathrm{C}$ NMR $\left(101 \mathrm{MHz}, \mathrm{DMSO}-\mathrm{d}_{6}\right) \delta 7.4$, 0.1. ${ }^{19} \mathrm{~F}$ NMR (377 MHz, DMSO-d 6 ) $\delta-131.1 .{ }^{11} \mathrm{~B}$ NMR $\left(128 \mathrm{MHz}, \mathrm{DMSO}-\mathrm{d}_{6}\right) \delta-2.1$ (q, $J=$ $37.5 \mathrm{~Hz}$ ). HRMS (ESI/QTOF) m/z: [M-K] ${ }^{-}$Calcd for $\mathrm{C}_{5} \mathrm{H}_{5} \mathrm{BF}_{3}{ }^{-}$133.0442; Found 133.0444.

\section{Potassium trifluoro(7-hydroxyhept-1-yn-1-yl)borate (24):}

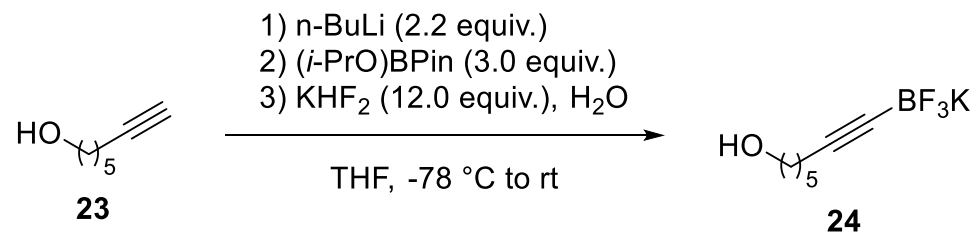

Compound 24 was synthesized following an adapted version of a reported procedure. ${ }^{13} \mathrm{An}$ oven-dried round-bottom flask (PFA) was evacuated and backfilled with $\mathrm{N}_{2}(3 \mathrm{x})$. Then, hept6-yn-1-ol (23) (0.94 mL, $7.5 \mathrm{mmol}, 1.0$ equiv.) and dry THF (25 mL) were added. The mixture was cooled to $-78{ }^{\circ} \mathrm{C}$ and a solution of $n$-BuLi $(6.60 \mathrm{~mL}, 16.5 \mathrm{mmol}, 2.5 \mathrm{M}, 2.2$ equiv.) in hexane was added dropwise under $\mathrm{N}_{2}$. The reaction was stirred at $-78{ }^{\circ} \mathrm{C}$ for $1 \mathrm{~h}$ and 2isopropoxy-4,4,5,5-tetramethyl-1,3,2-dioxaborolane (4.65 mL, $22.5 \mathrm{mmol}, 3.0$ equiv.) was added quickly. The reaction was warmed to $-20^{\circ} \mathrm{C}$ and stirred for $1 \mathrm{~h}$. A saturated solution of $\mathrm{KHF}_{2}$ (7.03 g, $90.0 \mathrm{mmol}, 12.0$ equiv.) in water $(20 \mathrm{~mL}+$ additional $10 \mathrm{~mL}$ to rinse the remaining solid) was added. The reaction was stirred at $\mathrm{rt}$ open to air for $1 \mathrm{~h}$ then concentrated in vacuo. The wet solid obtained was further dried by co-evaporation with acetone. To the dry

\footnotetext{
${ }^{13}$ J. D. Kirkham, S. J. Edeson, S. Stokes, J. P. A. Harrity, Org. Lett. 2012, 14, 5354-5357.
} 
solid was added acetone $(\sim 30 \mathrm{~mL})$ and the resulting mixture was placed on a rotary evaporator and rotated rapidly at atmospheric pressure with the bath set at $45^{\circ} \mathrm{C}$ for 15 minutes. The flask was removed and the mixture carefully filtered taking care to leave the insoluble material in the reaction flask. Acetone was once again added and the process (heating for $15 \mathrm{~min}$ then collection of the liquid) was repeated 2 more times. The combined acetone filtrates were concentrated in vacuo to approximately $1 / 3$ of the initial volume. $\mathrm{Et}_{2} \mathrm{O}(\sim 40 \mathrm{~mL})$ was added causing a white solid to precipitate. The mixture was cooled to $0{ }^{\circ} \mathrm{C}$ for $10 \mathrm{~min}$ then filtered. The solid obtained was washed with $\mathrm{Et}_{2} \mathrm{O}$ and dried in vacuo then recrystallized in acetone using $\mathrm{Et}_{2} \mathrm{O}$ to induce precipitation to afford potassium trifluoro(7-hydroxyhept-1-yn-1yl)borate (24) (0.91 g, $4.2 \mathrm{mmol}, 56 \%$ ) as a white solid. Mp (Dec.): $260{ }^{\circ} \mathrm{C} ;{ }^{1} \mathrm{H}$ NMR (400 MHz, DMSO-d 6 ) $\delta 4.34(\mathrm{t}, J=5.2 \mathrm{~Hz}, 1 \mathrm{H}), 3.37(\mathrm{q}, J=5.3 \mathrm{~Hz}, 2 \mathrm{H}), 2.01-1.92(\mathrm{~m}, 2 \mathrm{H}), 1.45$ -1.27 (m, 6H). ${ }^{13} \mathrm{C}$ NMR (101 MHz, DMSO-d 6$) \delta 60.7,32.2,29.0,25.0,19.0 .{ }^{19} \mathrm{~F}$ NMR (376 MHz, DMSO-d 6 ) $\delta$-131.0. ${ }^{11}$ B NMR (128 MHz, DMSO-d 6 ) $\delta$-1.9. HRMS (ESI/QTOF) m/z: $[\mathrm{M}-\mathrm{K}]^{-}$Calcd for $\mathrm{C}_{7} \mathrm{H}_{11} \mathrm{BF}_{3} \mathrm{O}^{-}$179.0861; Found 179.0862 .

Potassium (5-chloropent-1-yn-1-yl)trifluoroborate (25):

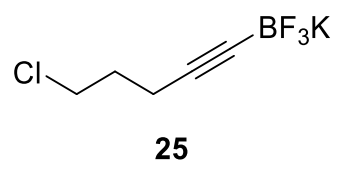

Synthesized following general procedure A starting from 5-chloropent-1-yne $(0.77 \mathrm{~g}, 0.80$ $\mathrm{mL}, 7.5 \mathrm{mmol}$ ). Potassium (5-chloropent-1-yn-1-yl)trifluoroborate (25) (1.28 g, $6.14 \mathrm{mmol}$, $82 \%)$ was obtained as a white solid. ${ }^{1} \mathrm{H} \mathrm{NMR}\left(400 \mathrm{MHz}\right.$, acetone- $\left.\mathrm{d}_{6}\right) \delta 3.70(\mathrm{t}, J=6.6 \mathrm{~Hz}, 2 \mathrm{H})$, $2.24-2.17(\mathrm{~m}, 2 \mathrm{H}), 1.85$ (p, $J=6.7 \mathrm{~Hz}, 2 \mathrm{H}) .{ }^{13} \mathrm{C} \mathrm{NMR}\left(101 \mathrm{MHz}\right.$, acetone-d $\left.\mathrm{d}_{6}\right) \delta 44.9,33.1$, 17.3. ${ }^{19} \mathrm{~F}$ NMR (376 MHz, acetone- $\left.\mathrm{d}_{6}\right) \delta$-134.6. Spectroscopic data was consistent with the values reported in the literature. ${ }^{9}$

Potassium trifluoro(4-(tosyloxy)but-1-yn-1-yl)borate (26):

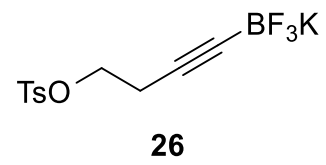

Synthesized following general procedure A starting from but-3-yn-1-yl 4methylbenzenesulfonate $(1.75 \mathrm{~g}, 1.73 \mathrm{~mL}, 7.5 \mathrm{mmol})$. Potassium trifluoro(4-(tosyloxy)but-1yn-1-yl)borate (26) $(1.9 \mathrm{~g}, 5.7 \mathrm{mmol}, 77 \%)$ was obtained as a beige solid. $\mathrm{Mp}$ (Dec.): $156{ }^{\circ} \mathrm{C}$; ${ }^{1} \mathrm{H}$ NMR (400 MHz, acetone-d 6 ) $\delta 7.88-7.81(\mathrm{~m}, 2 \mathrm{H}), 7.51-7.46(\mathrm{~m}, 2 \mathrm{H}), 3.99(\mathrm{t}, J=7.3 \mathrm{~Hz}$, $2 \mathrm{H}), 2.45(\mathrm{~s}, 3 \mathrm{H}), 2.38(\mathrm{tq}, J=7.3,1.8 \mathrm{~Hz}, 2 \mathrm{H}) .{ }^{13} \mathrm{C}$ NMR (101 MHz, acetone-d 6 ) $\delta 145.8$, 134.2, 130.9, 128.7, 70.0, 21.5, 20.8. ${ }^{19} \mathrm{~F}$ NMR (377 MHz, acetone-d 6 ) $\delta-135.0(\mathrm{dd}, J=71.8$, $32.1 \mathrm{~Hz}) .{ }^{11} \mathrm{~B}$ NMR $(128 \mathrm{MHz}$, acetone-d 6$) \delta-1.8(\mathrm{q}, J=37.0 \mathrm{~Hz}) . \mathrm{HRMS}($ ESI/QTOF) m/z: [M-K] $]^{-}$Calcd for $\mathrm{C}_{11} \mathrm{H}_{11} \mathrm{BF}_{3} \mathrm{O}_{3} \mathrm{~S}^{-}$291.0480; Found 291.0478. 


\section{Potassium trifluoro((3-methoxyphenyl)ethynyl)borate (27):}

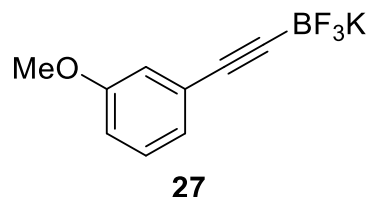

Synthesized following general procedure A starting from 1-ethynyl-3-methoxybenzene (1.0 $\mathrm{g}, 0.97 \mathrm{~mL}, 7.5 \mathrm{mmol})$. Potassium trifluoro((3-methoxyphenyl)ethynyl)borate (27) (0.91 g, 3.8 mmol, $51 \%$ ) was obtained as a white solid. ${ }^{1} \mathrm{H}$ NMR $\left(400 \mathrm{MHz}\right.$, acetone- $\left.\mathrm{d}_{6}\right) \delta 7.15(\mathrm{t}, J=8.0$ $\mathrm{Hz}, 1 \mathrm{H}), 6.93-6.84(\mathrm{~m}, 2 \mathrm{H}), 6.78(\mathrm{ddd}, J=8.3,2.7,1.0 \mathrm{~Hz}, 1 \mathrm{H}), 3.76(\mathrm{~s}, 3 \mathrm{H}) .{ }^{13} \mathrm{C} \mathrm{NMR}(101$ MHz, acetone- $\left.\mathrm{d}_{6}\right) \delta 160.3,129.8,128.3,124.5,117.1,113.7,55.4 .{ }^{19} \mathrm{~F}$ NMR $(377 \mathrm{MHz}$, acetone- $\left.\mathrm{d}_{6}\right) \delta-135.0(\mathrm{dd}, J=70.9,30.5 \mathrm{~Hz})$. Spectroscopic data was consistent with the values reported in the literature. ${ }^{14}$

\section{Potassium trifluoro((4-(methoxycarbonyl)phenyl)ethynyl)borate (29):}

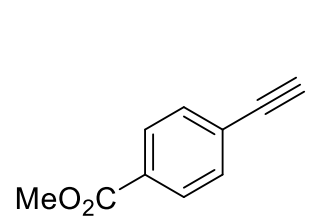

28

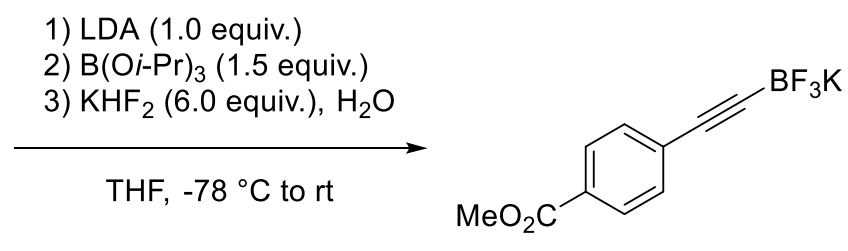

29

Compound 29 was synthesized following an adapted version of a reported procedure. ${ }^{8,15}$ An oven-dried round-bottom flask (PFA) was evacuated and backfilled with $\mathrm{N}_{2}(3 \mathrm{x})$. Then, freshly distilled diisopropylamine (1.05 mL, $7.50 \mathrm{mmol}, 1.0$ equiv.) and dry THF (15 mL) were added. The mixture was cooled to $0{ }^{\circ} \mathrm{C}$ and a solution of $n$-BuLi (3.0 mL, 7.5 mmol, 2.5 M, 1.0 equiv.) in hexane was added dropwise under $\mathrm{N}_{2}$. The reaction was stirred at $0{ }^{\circ} \mathrm{C}$ for $0.5 \mathrm{~h}$ then cooled to $-78{ }^{\circ} \mathrm{C}$. A solution of methyl 4-ethynylbenzoate ( $1.2 \mathrm{~g}, 7.5 \mathrm{mmol}, 1.0 \mathrm{equiv}$.) in dry THF (10 $\mathrm{mL})$ was added dropwise. The reaction was stirred at $-78^{\circ} \mathrm{C}$ for $0.5 \mathrm{~h}$ then $\mathrm{B}(\mathrm{O} i-\mathrm{Pr})_{3}(2.60 \mathrm{~mL}$, $11.3 \mathrm{mmol}, 1.5$ equiv.) was added quickly. The reaction was stirred $10 \mathrm{~min}$ at $-78{ }^{\circ} \mathrm{C}$ then $2 \mathrm{~h}$ at rt. The mixture was cooled to $0{ }^{\circ} \mathrm{C}$ and a saturated solution of $\mathrm{KHF}_{2}(3.52 \mathrm{~g}, 45.0 \mathrm{mmol}, 6.0$ equiv.) in water $(10 \mathrm{~mL}+$ additional $10 \mathrm{~mL}$ to rinse the remaining solid) was added. The reaction was stirred at $\mathrm{rt}$ open to air for $2 \mathrm{~h}$ then concentrated in vacuo. The wet solid obtained was further dried by co-evaporation with acetone. To the dry solid was added acetone $(\sim 30 \mathrm{~mL})$ and the resulting mixture was placed on a rotary evaporator and rotated rapidly at atmospheric pressure with the bath set at $45{ }^{\circ} \mathrm{C}$ for 15 minutes. The flask was removed and the mixture carefully filtered taking care to leave the insoluble material in the reaction flask. Acetone was

\footnotetext{
14 J. H. Song, P. Choi, S. E. Lee, K. H. Jeong, T. Kim, K. S. Kang, Y. S. Choi, J. Ham, Eur. J. Org. Chem. 2013, 2013, 6249-6253.

${ }^{15}$ For LDA preparation see: S. Jansone-Popova, J. A. May, J. Am. Chem. Soc. 2012, 134, 17877-17880.
} 
once again added and the process (heating for $15 \mathrm{~min}$ then collection of the liquid) was repeated 2 more times. The combined acetone filtrates were concentrated in vacuo to approximately $1 / 3$ of the initial volume. $\mathrm{Et}_{2} \mathrm{O}(\sim 40 \mathrm{~mL})$ was added causing a white solid to precipitate. The mixture was cooled to $0{ }^{\circ} \mathrm{C}$ for $10 \mathrm{~min}$ then filtered. The solid obtained was washed with $\mathrm{Et}_{2} \mathrm{O}$ and dried in vacuo to afford potassium trifluoro((4-(methoxycarbonyl)phenyl)ethynyl)borate (29) (0.80 $\mathrm{g}, 3.0 \mathrm{mmol}, 40 \%$ ) as a beige solid. Mp (Dec.): $220{ }^{\circ} \mathrm{C} ;{ }^{1} \mathrm{H} \mathrm{NMR}(400 \mathrm{MHz}$, acetone-d 6 ) $\delta 7.92$ $-7.85(\mathrm{~m}, 2 \mathrm{H}), 7.45-7.38(\mathrm{~m}, 2 \mathrm{H}), 3.86(\mathrm{~s}, 3 \mathrm{H}) .{ }^{13} \mathrm{C}$ NMR (101 MHz, acetone- $\left.\mathrm{d}_{6}\right) \delta 167.0$, 132.5, 132.1, 129.9, 128.7, 52.3. ${ }^{19} \mathrm{~F}$ NMR (376 MHz, acetone- $\left.\mathrm{d}_{6}\right) \delta-135.4 .{ }^{11} \mathrm{~B}$ NMR (128 $\mathrm{MHz}$, acetone- $\left.\mathrm{d}_{6}\right) \delta-1.4(\mathrm{q}, J=34.8 \mathrm{~Hz})$. HRMS (ESI/QTOF) $\mathrm{m} / \mathrm{z}:[\mathrm{M}-\mathrm{K}]^{-}$Calcd for $\mathrm{C}_{10} \mathrm{H}_{7} \mathrm{BF}_{3} \mathrm{O}_{2}^{-}$227.0497; Found 227.0501.

Potassium trifluoro((4-fluorophenyl)ethynyl)borate (30):

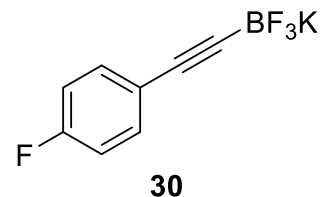

Synthesized following general procedure A starting from 1-ethynyl-4-fluorobenzene $(0.90 \mathrm{~g}$, $0.86 \mathrm{~mL}, 7.5 \mathrm{mmol})$. Potassium trifluoro((4-fluorophenyl)ethynyl)borate (30) (1.11 g, 4.91 mmol, 65\%) was obtained as a white solid. ${ }^{1} \mathrm{H}$ NMR (400 MHz, DMSO-d 6 ) $\delta 7.36-7.28$ (m, 2H), $7.14-7.07(\mathrm{~m}, 2 \mathrm{H}) .{ }^{1} \mathrm{H}$ NMR (400 MHz, acetone-d 6$) \delta 7.38-7.30(\mathrm{~m}, 2 \mathrm{H}), 7.06-6.98$ $(\mathrm{m}, 2 \mathrm{H}) .{ }^{13} \mathrm{C}$ NMR $(101 \mathrm{MHz}$, acetone-d 6$) \delta 162.2(\mathrm{~d}, J=244.5 \mathrm{~Hz}), 134.0(\mathrm{~d}, J=8.0 \mathrm{~Hz})$, 123.7, $115.8(\mathrm{~d}, J=21.9 \mathrm{~Hz}) .{ }^{19} \mathrm{~F}$ NMR $\left(376 \mathrm{MHz}\right.$, acetone- $\left.\mathrm{d}_{6}\right) \delta-115.9,-135.1$. Spectroscopic data was consistent with the values reported in the literature. ${ }^{8}$

Potassium

trifluoro(( $(8 R, 9 S, 13 S, 14 S, 17 S)$-17-hydroxy-3-methoxy-13-methyl$7,8,9,11,12,13,14,15,16,17-d e c a h y d r o-6 H$-cyclopenta[a]phenanthren-17yl)ethynyl)borate (32):

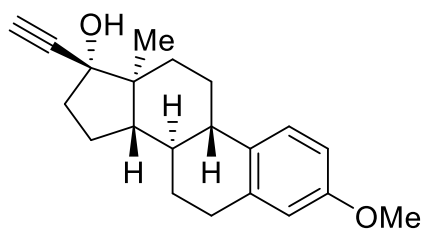

31

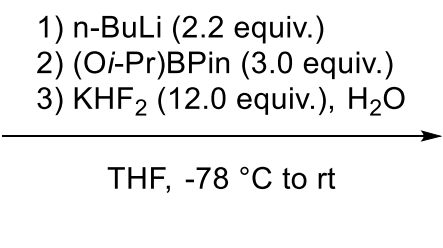

2) (Oi-Pr)BPin (3.0 equiv.)

3) $\mathrm{KHF}_{2}$ (12.0 equiv.), $\mathrm{H}_{2} \mathrm{O}$

$\mathrm{THF},-78^{\circ} \mathrm{C}$ to $\mathrm{rt}$

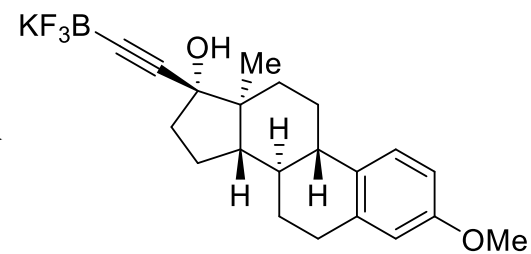

32

Compound 32 was synthesized following an adapted version of a reported procedure. ${ }^{13}$ An oven-dried round-bottom flask (PFA) charged with $(8 R, 9 S, 13 S, 14 S, 17 R)$-17-ethynyl-3methoxy-13-methyl-7,8,9,11,12,13,14,15,16,17-decahydro-6H-cyclopenta[a]phenanthren-17ol (31) (1.0 g, 3.2 mmol, 1.0 equiv.) was evacuated and backfilled with $\mathrm{N}_{2}$ (3x). Dry THF (22 $\mathrm{mL}$ ) was added, the mixture was cooled to $-78^{\circ} \mathrm{C}$ and a solution of $n$-BuLi $(2.8 \mathrm{~mL}, 7.1 \mathrm{mmol}$, $2.5 \mathrm{M}, 2.2$ equiv.) in hexane was added dropwise under $\mathrm{N}_{2}$. The reaction was stirred at $-78{ }^{\circ} \mathrm{C}$ for $1 \mathrm{~h}$ and 2-isopropoxy-4,4,5,5-tetramethyl-1,3,2-dioxaborolane $(2.0 \mathrm{~mL}, 9.7 \mathrm{mmol}, 3.0$ 
equiv.) was added quickly. The reaction was warmed to $-20{ }^{\circ} \mathrm{C}$ and stirred for $1 \mathrm{~h}$. A saturated solution of $\mathrm{KHF}_{2}$ (3.02 g, $38.7 \mathrm{mmol}, 12.0$ equiv.) in water $(9 \mathrm{~mL}+$ additional $9 \mathrm{~mL}$ to rinse the remaining solid) was added. The reaction was stirred at $\mathrm{rt}$ open air for $1 \mathrm{~h}$ then concentrated in vacuo. The wet solid obtained was further dried by co-evaporation with acetone. To the dry solid was added acetone $(\sim 30 \mathrm{~mL})$ and the resulting mixture was placed on a rotary evaporator and rotated rapidly at atmospheric pressure with the bath set at $45^{\circ} \mathrm{C}$ for 15 minutes. The flask was removed and the mixture carefully filtered taking care to leave the insoluble material in the reaction flask. Acetone was once again added and the process (heating for $15 \mathrm{~min}$ then collection of the liquid) was repeated 2 more times. The combined acetone filtrates were concentrated in vacuo to approximately $1 / 3$ of the initial volume. $\mathrm{Et}_{2} \mathrm{O}(\sim 40 \mathrm{~mL})$ was added causing a white solid to precipitate. The mixture was cooled to $0{ }^{\circ} \mathrm{C}$ for $10 \mathrm{~min}$ then filtered. The solid obtained was washed with $\mathrm{Et}_{2} \mathrm{O}$, dried in vacuo then recrystallized in acetone using $\mathrm{Et}_{2} \mathrm{O}$ to induce precipitation to afford potassium trifluoro(( $\left.8 R, 9 S, 13 S, 14 S, 17 S\right)$-17-hydroxy-3methoxy-13-methyl-7,8,9,11,12,13,14,15,16,17-decahydro- $6 H$-cyclopenta[ $a]$ phenanthren-17yl)ethynyl)borate (32) $(0.53 \mathrm{~g}, 1.3 \mathrm{mmol}, 40 \%)$ as a white solid. Mp (Dec.): $257{ }^{\circ} \mathrm{C} ;{ }^{1} \mathrm{H}$ NMR $\left(400 \mathrm{MHz}, \mathrm{DMSO}_{\left.-\mathrm{d}_{6}\right)} \delta 7.18(\mathrm{~d}, J=8.6 \mathrm{~Hz}, 1 \mathrm{H}), 6.67(\mathrm{dd}, J=8.6,2.8 \mathrm{~Hz}, 1 \mathrm{H}), 6.59(\mathrm{~d}, J=\right.$ $2.7 \mathrm{~Hz}, 1 \mathrm{H}), 4.79$ (s, 1H), 3.69 (s, 3H), 2.77 (q, J=4.3 Hz, 2H), $2.38-2.23$ (m, 1H), 2.02 (ddd, $J=12.9,9.9,6.1 \mathrm{~Hz}, 2 \mathrm{H}), 1.91(\mathrm{td}, J=13.2,4.2 \mathrm{~Hz}, 1 \mathrm{H}), 1.85-1.72(\mathrm{~m}, 2 \mathrm{H}), 1.72-1.52(\mathrm{~m}$, $3 \mathrm{H}), 1.35-1.17(\mathrm{~m}, 4 \mathrm{H}), 0.71(\mathrm{~s}, 3 \mathrm{H}) .{ }^{13} \mathrm{C} \mathrm{NMR}\left(101 \mathrm{MHz}, \mathrm{DMSO}-\mathrm{d}_{6}\right){ }^{16} \delta 157.0,137.4,132.3$, 126.2, 113.4, 111.5, 78.2, 54.9, 48.6, 46.5, 43.3, 32.6, 29.4, 27.0, 26.3, 22.6, 13.0. ${ }^{19} \mathrm{~F} \mathrm{NMR}$ $\left(376 \mathrm{MHz}, \mathrm{DMSO}-\mathrm{d}_{6}\right) \delta-130.6 .{ }^{11} \mathrm{~B}$ NMR (128 MHz, DMSO-d 6 ) $\delta$-1.7. HRMS (ESI/QTOF) $\mathrm{m} / \mathrm{z}$ : [M-K] ${ }^{-}$Calcd for $\mathrm{C}_{21} \mathrm{H}_{25} \mathrm{BF}_{3} \mathrm{O}_{2}^{-}$377.1905; Found 377.1919.

\section{Potassium ethynyltrifluoroborate (34):}

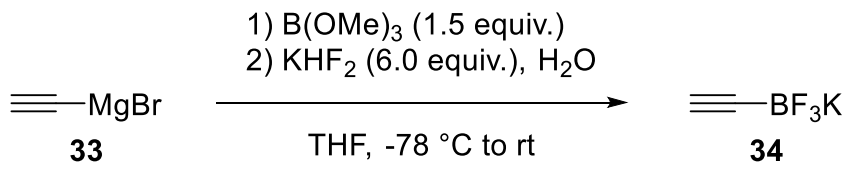

Compound 34 was synthesized following an adapted version of a reported procedure. ${ }^{12}$ An oven-dried round-bottom flask (PFA) was evacuated and backfilled with $\mathrm{N}_{2}(3 \mathrm{x})$. Then, a solution of ethynylmagnesium bromide (33) $(30.0 \mathrm{~mL}, 15.0 \mathrm{mmol}, 0.5 \mathrm{M}, 1.0$ equiv.) in THF and dry THF $(30 \mathrm{~mL})$ were added. The solution was cooled to $-78{ }^{\circ} \mathrm{C}$ and $\mathrm{B}(\mathrm{OMe})_{3}(2.5 \mathrm{~mL}$, $22 \mathrm{mmol}, 1.5$ equiv.) was added quickly under $\mathrm{N}_{2}$. The reaction was stirred $1 \mathrm{~h}$ at $-78{ }^{\circ} \mathrm{C}$ then $1.5 \mathrm{~h}$ at $-20^{\circ} \mathrm{C}$. A saturated solution of $\mathrm{KHF}_{2}(7.03 \mathrm{~g}, 90.0 \mathrm{mmol}, 6.0$ equiv. $)$ in water $(20 \mathrm{~mL}$ + additional $20 \mathrm{~mL}$ to rinse the remaining solid) was added. The reaction was stirred at rt open air for $2 \mathrm{~h}$ then concentrated in vacuo. The wet solid obtained was further dried by coevaporation with acetone. To the dry solid was added acetone $(\sim 30 \mathrm{~mL})$ and the resulting mixture was placed on a rotary evaporator and rotated rapidly at atmospheric pressure with the bath set at $45^{\circ} \mathrm{C}$ for 15 minutes. The flask was removed and the mixture carefully filtered taking

\footnotetext{
${ }^{16}$ Two carbon signals are hidden under the DMSO signal.
} 
care to leave the insoluble material in the reaction flask. Acetone was once again added and the process (heating for $15 \mathrm{~min}$ then collection of the liquid) was repeated 2 more times. The combined acetone filtrates were concentrated in vacuo to approximately $1 / 3$ of the initial volume. $\mathrm{Et}_{2} \mathrm{O}(\sim 30 \mathrm{~mL})$ was added causing a white solid to precipitate. The mixture was cooled to $0{ }^{\circ} \mathrm{C}$ for $10 \mathrm{~min}$ then filtered. The solid obtained was washed with $\mathrm{Et}_{2} \mathrm{O}$ and dried in vacuo to afford potassium ethynyltrifluoroborate (34) (1.17 g, $8.86 \mathrm{mmol}, 59 \%)$ as a white solid. Mp (Dec.): $216{ }^{\circ} \mathrm{C} ;{ }^{1} \mathrm{H}$ NMR (400 MHz, acetone-d 6$) \delta 1.67(\mathrm{~d}, J=5.4 \mathrm{~Hz}, 1 \mathrm{H}) .{ }^{13} \mathrm{C}$ NMR $(101$ $\mathrm{MHz}$, acetone- $\mathrm{d}_{6}$ ) not observed. ${ }^{19} \mathrm{~F}$ NMR $\left(376 \mathrm{MHz}\right.$, acetone-d $\left.\mathrm{d}_{6}\right) \delta-135.5 .{ }^{11} \mathrm{~B}$ NMR (128 MHz, acetone-d 6 ) $\delta-2.0$ (qd, $J=36.1,3.7 \mathrm{~Hz}$ ). HRMS (nanochip-ESI/LTQ-Orbitrap) m/z: [M$\mathrm{K}]^{-}$Calcd for $\mathrm{C}_{2} \mathrm{HBF}_{3}^{-}$93.0129; Found 93.0128.

\section{Potassium (2,3-dihydro-1H-inden-2-yl)trifluoroborate (37):}

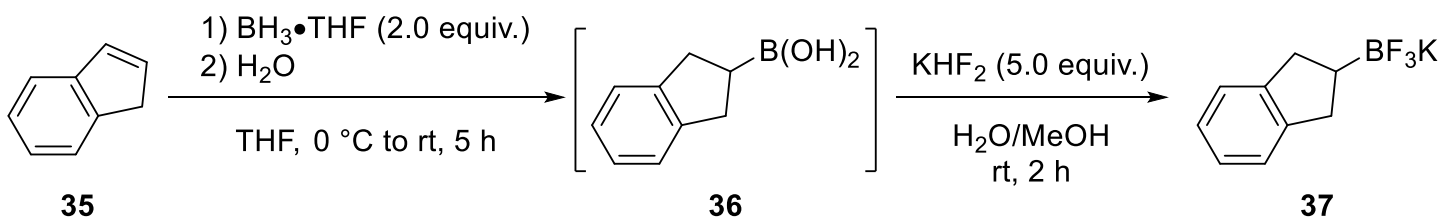

Compound 37 was synthesized following an adapted version of a reported procedure. ${ }^{17}$ An oven dried round-bottom flask was evacuated and backfilled with $\mathrm{N}_{2}(3 \mathrm{x})$. A solution of $\mathrm{BH}_{3} \cdot \mathrm{THF}$ (40.0 mL, $40.0 \mathrm{mmol}, 1 \mathrm{M}, 2.0$ equiv.) was added and cooled to $0{ }^{\circ} \mathrm{C}$. A solution of indene (35) ( $2.3 \mathrm{~mL}, 20.0 \mathrm{mmol}, 1.0$ equiv.) in dry THF ( $4 \mathrm{~mL}$ ) was added under $\mathrm{N}_{2}$ and the reaction was warm to $\mathrm{rt}$ and stirred for $2 \mathrm{~h}$. The mixture was cooled to $0{ }^{\circ} \mathrm{C}$ and water $(4 \mathrm{~mL})$ was added dropwise. The reaction was stirred at $\mathrm{rt}$ for $3 \mathrm{~h}$. The mixture was concentrated in vacuo to remove the THF then EtOAc $(50 \mathrm{~mL})$ was added. The organic layer was collected, washed with water $(25 \mathrm{~mL})$ and brine $(2 \times 25 \mathrm{~mL})$, dried over $\mathrm{MgSO}_{4}$, filtered and concentrated in vacuo to afford crude boronic acid $\mathbf{3 6}$ as an oil.

To a round-bottom flask (PFA) charged with a saturated solution of $\mathrm{KHF}_{2}(7.81 \mathrm{~g}, 100 \mathrm{mmol}$, 5.0 equiv.) in water $(30 \mathrm{~mL})$ was added a solution of crude 36 in $\mathrm{MeOH}(40 \mathrm{~mL})$. The reaction was stirred at $\mathrm{rt}$ open air for $2 \mathrm{~h}$ then was concentrated in vacuo. The wet solid obtained was further dried by co-evaporation with acetone. To the dry solid was added acetone $(\sim 30 \mathrm{~mL})$ and the resulting mixture was placed on a rotary evaporator and rotated rapidly at atmospheric pressure with the bath set at $45{ }^{\circ} \mathrm{C}$ for 15 minutes. The flask was removed and the mixture carefully filtered taking care to leave the insoluble material in the reaction flask. Acetone was once again added and the process (heating for $15 \mathrm{~min}$ then collection of the liquid) was repeated 2 more times. The combined acetone filtrates were concentrated in vacuo to approximately $1 / 3$ of the initial volume. $\mathrm{Et}_{2} \mathrm{O}(\sim 40 \mathrm{~mL})$ was added causing a white solid to precipitate. The mixture was cooled to $0{ }^{\circ} \mathrm{C}$ for $10 \mathrm{~min}$ then filtered. The solid obtained was washed with $\mathrm{Et}_{2} \mathrm{O}$ and dried in vacuo to afford potassium (2,3-dihydro- $1 H$-inden-2-yl)trifluoroborate (37) $(1.55 \mathrm{~g}, 6.90$

\footnotetext{
${ }^{17}$ W.-Z. Weng, H. Liang, B. Zhang, Org. Lett. 2018, 20, 4979-4983.
} 
mmol, 34\%) as a white solid. ${ }^{1} \mathrm{H}$ NMR (400 MHz, acetone-d $\left.{ }_{6}\right) \delta 7.07$ (dd, $\left.J=5.3,3.3 \mathrm{~Hz}, 2 \mathrm{H}\right)$, $6.95(\mathrm{dd}, J=5.5,3.1 \mathrm{~Hz}, 2 \mathrm{H}), 2.75(\mathrm{dd}, J=9.9,3.6 \mathrm{~Hz}, 4 \mathrm{H}), 1.38-1.21(\mathrm{~m}, 1 \mathrm{H}) .{ }^{13} \mathrm{C} \mathrm{NMR}$ $\left(101 \mathrm{MHz}\right.$, acetone- $\left.\mathrm{d}_{6}\right) \delta 148.3,125.6,124.6,36.8 .{ }^{19} \mathrm{~F}$ NMR (376 MHz, acetone- $\left.\mathrm{d}_{6}\right) \delta-146.3$ (d, $J=92.8 \mathrm{~Hz}$ ). Spectroscopic data was consistent with the values reported in the literature. ${ }^{18}$

\section{Purification-free Synthesis of EBX Reagents}

\section{Optimization procedure:}<smiles>[Y]I1OC(=O)c2ccccc21</smiles>

1

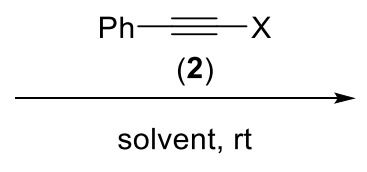

solvent, rt<smiles>O=C1OI(C#Cc2ccccc2)c2ccccc21</smiles>

$3 a$

A capped oven dried microwave vial charged with hypervalent iodine reagent $1(0.10 \mathrm{mmol}$, 1.0 equiv.) and alkyne 2 (1.05-1.50 equiv.) was evacuated and backfilled with $\mathrm{N}_{2}$ ( $3 \mathrm{x}$ ). Solvent was added under $\mathrm{N}_{2}$ and the reaction was stirred at $\mathrm{rt}$ for the indicated amount of time. To the mixture was added a sat. sol. of $\mathrm{NaHCO}_{3}(2 \mathrm{~mL})$ and the mixture was vigorously stirred open to air for $1 \mathrm{~h}$. Water $(2 \mathrm{~mL})$ was added and the mixture was extracted with $4 \times 3 \mathrm{~mL}$ of DCM, the combined organic layers were dried over $\mathrm{MgSO}_{4}$, filtered and concentrated in vacuo to afford 3a. ${ }^{1} \mathrm{H}$ NMR yield was determined dissolving 3a in $\mathrm{CDCl}_{3}$ and adding $\mathrm{CH}_{2} \mathrm{Br}_{2}(3.6 \mu \mathrm{L}$, $0.051 \mathrm{mmol}, 0.51$ equiv.) as internal standard.

\section{General procedure B:}<smiles>O=C1OI([O-])c2ccccc21</smiles>

1b

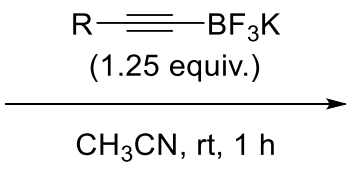

$\mathrm{CH}_{3} \mathrm{CN}, \mathrm{rt}, 1 \mathrm{~h}$<smiles>[R]C#CI1COC(=O)c2ccccc21</smiles>

3

A capped oven dried microwave vial charged with 1-(p-methylbenzenesulfonyloxy)-1,2benziodoxol-3-(1H)-one (1b) (167 mg, $0.400 \mathrm{mmol}, 1.0$ equiv.) and potassium alkynyltrifluoroborate ( $0.50 \mathrm{mmol}, 1.25$ equiv.) was evacuated and backfilled with $\mathrm{N}_{2}(3 \mathrm{x})$. Dry acetonitrile $(4 \mathrm{~mL})$ was added under $\mathrm{N}_{2}$ and the reaction was stirred at $\mathrm{rt}$ for $1 \mathrm{~h}$. To the mixture was added a sat. sol. of $\mathrm{NaHCO}_{3}(8 \mathrm{~mL})$ and the mixture was vigorously stirred open to air for $1 \mathrm{~h}$. Water $(10 \mathrm{~mL})$ was added and the mixture was extracted with $3 \times 20 \mathrm{~mL}$ of DCM, the combined organic layers were dried over $\mathrm{MgSO}_{4}$, filtered and concentrated in vacuo. The crude EBX was triturated in pentane, which induced precipitation if it was an oil. The pentane layer

\footnotetext{
${ }^{18}$ H. Huang, G. Zhang, L. Gong, S. Zhang, Y. Chen, J. Am. Chem. Soc. 2014, 136, 2280-2283.
} 
was discarded with care to leave the solid in the flask. This process was repeated 2 more times then the solid was dried in vacuo to afford $\mathbf{3}$.

Note: Purity of the product obtained was determined using ${ }^{1} \mathrm{H}$ NMR by dissolving the entirety of the compound in $\mathrm{CDCl}_{3}(\sim 4 \mathrm{~mL})$ and adding $\mathrm{CH}_{2} \mathrm{Br}_{2}(14.0 \mu \mathrm{L}, 0.1975 \mathrm{mmol}, 0.49$ equiv.) as internal standard.

Purity is determined based on the signal of $\mathrm{CH}_{2} \mathrm{Br}_{2}(4.93 \mathrm{ppm})$ normalize at $\mathrm{I}=1$ and an aromatic signal of the EBX corresponding to $1 \mathrm{H}$ :

$$
\begin{gathered}
n(E B X)_{e f f}=\frac{\frac{I_{E B X}}{N_{E B X}} * n_{s t d} * N_{s t d}}{I_{\text {std }}}=\frac{\frac{I_{E B X}}{1} * 0.1975 * 2}{1}=I_{E B X} * 0.3950 \\
p_{E B X}=\frac{n(E B X)_{\text {eff }}}{n(E B X)_{\text {theo }}}=\frac{n(E B X)_{\text {eff }}}{\frac{m_{E B X}}{M W_{E B X}}}
\end{gathered}
$$

$\mathrm{n}(\mathrm{EBX})_{\text {eff: }}$ moles of EBX determined by NMR (in mmol).

$\mathrm{n}(\mathrm{EBX})_{\text {theo: }}$ : moles of EBX calculated from the mass obtained if $100 \%$ pure (in mmol).

IEBX: Integral of the EBX signal.

$\mathrm{I}_{\text {std }}$ : Integral of the standard $\left(\mathrm{CH}_{2} \mathrm{Br}_{2}\right)$ signal.

$\mathrm{N}_{\mathrm{EBX}}$ : Number of protons corresponding the EBX signal.

$\mathrm{N}_{\text {std: }}$ : Number of protons corresponding the standard $\left(\mathrm{CH}_{2} \mathrm{Br}_{2}\right)$ signal.

$\mathrm{m}_{\mathrm{EBX}}$ : mass of EBX obtained at the end of the reaction (in $\mathrm{mg}$ ).

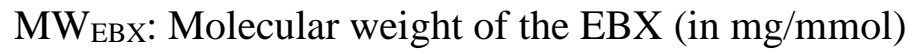

pEBX: purity of the EBX

1-[Phenylethynyl]-1,2-benziodoxol-3-(1H)-one (3a):<smiles>O=C1OI(C#Cc2ccccc2)c2ccccc21</smiles>

3a

Synthesized following general procedure $\mathbf{B}$ starting from potassium trifluoro(phenylethynyl)borate $\quad(\mathbf{2 a}) \quad(104 \quad \mathrm{mg}, \quad 0.500 \quad \mathrm{mmol}) . \quad 1-[P h e n y l e t h y n y l]-1,2-$ benziodoxol-3-(1H)-one (3a) (119.7 $\mathrm{mg}, 0.3318 \mathrm{mmol}, 83 \%$, 97\% purity) was obtained as a slightly yellow solid. ${ }^{1} \mathrm{H}$ NMR $\left(400 \mathrm{MHz}, \mathrm{CDCl}_{3}\right) \delta 8.46-8.37(\mathrm{~m}, 1 \mathrm{H}), 8.29-8.22(\mathrm{~m}, 1 \mathrm{H})$, $7.81-7.72(\mathrm{~m}, 2 \mathrm{H}), 7.63-7.57(\mathrm{~m}, 2 \mathrm{H}), 7.52-7.39(\mathrm{~m}, 3 \mathrm{H}) .{ }^{13} \mathrm{C} \mathrm{NMR}\left(101 \mathrm{MHz}, \mathrm{CDCl}_{3}\right) \delta$ 
$166.8,135.0,133.0,132.6,131.7,131.5,130.9,128.9,126.4,120.7,116.3,106.7,50.3$. Spectroscopic data was consistent with the values reported in the literature. ${ }^{19}$

$$
\begin{gathered}
n(E B X)_{\text {eff }}=0.84 * 0.3950=0.3318 \mathrm{mmol} \\
p_{E B X}=\frac{0.3318}{\frac{119.7}{348.14}}=0.9651=97 \% \text { purity }
\end{gathered}
$$

\section{1-[Mesitylethynyl]-1,2-benziodoxol-3-(1H)-one (3b):}

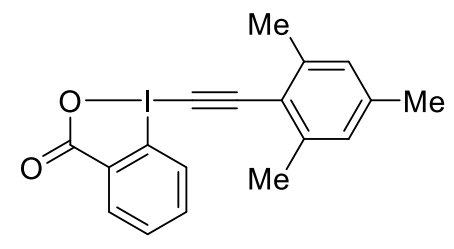

3b

Synthesized following general procedure B starting from potassium trifluoro(mesitylethynyl)borate (17) $(125 \mathrm{mg}, 0.500 \mathrm{mmol})$. The reaction was stirred at $\mathrm{rt}$ for 2 h. 1-[Mesitylethynyl]-1,2-benziodoxol-3-(1H)-one (3b) (148.2 mg, 0.3792 mmol, 95\%, 99\% purity) was obtained as a white solid. ${ }^{1} \mathrm{H}$ NMR $\left(400 \mathrm{MHz}, \mathrm{CDCl}_{3}\right) \delta 8.46-8.38(\mathrm{~m}, 1 \mathrm{H}), 8.33$ - $8.25(\mathrm{~m}, 1 \mathrm{H}), 7.79-7.71(\mathrm{~m}, 2 \mathrm{H}), 6.95(\mathrm{~s}, 2 \mathrm{H}), 2.47(\mathrm{~s}, 6 \mathrm{H}), 2.34$ (s, 3H). ${ }^{13} \mathrm{C}$ NMR $(101$ $\left.\mathrm{MHz}, \mathrm{CDCl}_{3}\right) \delta 166.7,142.4,141.0,134.9,132.7,131.7,131.6,128.3,126.2,117.6,116.7$, 105.6, 55.7, 21.7, 21.3. Spectroscopic data was consistent with the values reported in the literature. ${ }^{20}$

$$
\begin{gathered}
n(E B X)_{\text {eff }}=0.96 * 0.3950=0.3792 \mathrm{mmol} \\
p_{E B X}=\frac{0.3792}{\frac{148.2}{390.21}}=0.9984=99 \% \text { purity }
\end{gathered}
$$

1-[(Triisopropylsilyl)ethynyl]-1,2-benziodoxol-3-(1H)-one (3c):<smiles>O=C1OI(C#C[In])c2ccccc21</smiles>

\footnotetext{
${ }^{19}$ D. P. Hari, J. Waser, J. Am. Chem. Soc. 2016, 138, 2190-2193.

${ }^{20}$ R. Frei, M. D. Wodrich, D. P. Hari, P. A. Borin, C. Chauvier, J. Waser, J. Am. Chem. Soc. 2014, 136, 16563-16573.
} 
Synthesized following general procedure B starting from Potassium trifluoro((triisopropylsilyl)ethynyl)borate $\quad(\mathbf{1 8}) \quad(144 \quad \mathrm{mg}, \quad 0.500 \quad \mathrm{mmol}) . \quad 1$ [(Triisopropylsilyl)ethynyl]-1,2-benziodoxol-3-(1H)-one (3c) $(159.9 \mathrm{mg}, 0.3713 \mathrm{mmol}, 93 \%$, 99\% purity) as a white solid. ${ }^{1} \mathrm{H}$ NMR $\left(400 \mathrm{MHz}, \mathrm{CDCl}_{3}\right) \delta 8.44-8.37(\mathrm{~m}, 1 \mathrm{H}), 8.33-8.24$ $(\mathrm{m}, 1 \mathrm{H}), 7.79-7.70(\mathrm{~m}, 2 \mathrm{H}), 1.18-1.10(\mathrm{~m}, 21 \mathrm{H}) .{ }^{13} \mathrm{C} \mathrm{NMR}\left(101 \mathrm{MHz}, \mathrm{CDCl}_{3}\right) \delta 166.6$, $134.8,132.5,131.6,131.6,126.2,115.7,114.3,64.8,18.6,11.3$. Spectroscopic data was consistent with the values reported in the literature. ${ }^{19}$

$$
\begin{gathered}
n(E B X)_{e f f}=0.94 * 0.3950=0.3713 \mathrm{mmol} \\
p_{E B X}=\frac{0.3713}{\frac{159.9}{428.38}}=0.9947=99 \% \text { purity }
\end{gathered}
$$

\section{1-[Oct-1-yn-1-yl]-1,2-benziodoxol-3-(1H)-one (3d):}

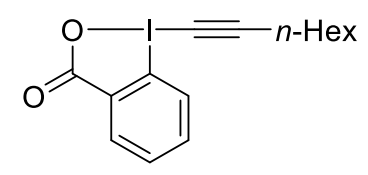

$3 \mathbf{d}$

Synthesized following general procedure B starting from Potassium trifluoro(oct-1-yn-1yl)borate (19) (108 mg, $0.500 \mathrm{mmol})$. 1-[Oct-1-yn-1-yl]-1,2-benziodoxol-3-(1H)-one (3d) (134.8 mg, $0.3753 \mathrm{mmol}, 94 \%, 99 \%$ purity) as a white solid. ${ }^{1} \mathrm{H}$ NMR (400 $\left.\mathrm{MHz}, \mathrm{CDCl}_{3}\right) \delta$ $8.42-8.34(\mathrm{~m}, 1 \mathrm{H}), 8.21-8.13(\mathrm{~m}, 1 \mathrm{H}), 7.78-7.68(\mathrm{~m}, 2 \mathrm{H}), 2.58(\mathrm{t}, J=7.1 \mathrm{~Hz}, 2 \mathrm{H}), 1.64(\mathrm{p}$, $J=7.2 \mathrm{~Hz}, 2 \mathrm{H}), 1.50-1.39(\mathrm{~m}, 2 \mathrm{H}), 1.38-1.25(\mathrm{~m}, 4 \mathrm{H}), 0.90(\mathrm{t}, J=7.0 \mathrm{~Hz}, 3 \mathrm{H}) .{ }^{13} \mathrm{C} \mathrm{NMR}$ $\left(101 \mathrm{MHz} \mathrm{CDCl}_{3}\right) \delta 166.6,134.7,132.5,131.7,131.6,126.2,115.7,109.9,39.4,31.3,28.7$, $28.3,22.6,20.6,14.2$. Spectroscopic data was consistent with the values reported in the literature. $^{20}$

$$
\begin{gathered}
n(E B X)_{e f f}=0.95 * 0.3950=0.3753 \mathrm{mmol} \\
p_{E B X}=\frac{0.3753}{\frac{134.8}{356.20}}=0.9917=99 \% \text { purity }
\end{gathered}
$$

\section{1-[Prop-1-yn-1-yl]-1,2-benziodoxol-3-(1H)-one (3e):}<smiles>CC#CI1COC(=O)c2ccccc21</smiles>

$3 e$

Synthesized following general procedure B starting from potassium trifluoro(prop-1-yn-1yl)borate (21) $(73.0 \mathrm{mg}, 0.500 \mathrm{mmol}) .1$-[Prop-1-yn-1-yl]-1,2-benziodoxol-3-(1H)-one (3e) 
(105.9 mg, $0.3476 \mathrm{mmol}, 87 \%, 94 \%$ purity) as a white solid. ${ }^{1} \mathrm{H} \mathrm{NMR}\left(400 \mathrm{MHz}, \mathrm{CDCl}_{3}\right) \delta$ $8.41-8.33(\mathrm{~m}, 1 \mathrm{H}), 8.22-8.13(\mathrm{~m}, 1 \mathrm{H}), 7.79-7.67(\mathrm{~m}, 2 \mathrm{H}), 2.26(\mathrm{~s}, 3 \mathrm{H}) .{ }^{13} \mathrm{C}$ NMR $(101$ $\left.\mathrm{MHz}, \mathrm{CDCl}_{3}\right)^{21} \delta 166.6,134.8,132.5,131.6,126.3,115.6,105.1,39.0,5.7$. Spectroscopic data was consistent with the values reported in the literature. ${ }^{20}$

$$
\begin{gathered}
n(E B X)_{e f f}=0.88 * 0.3950=0.3476 \mathrm{mmol} \\
p_{E B X}=\frac{0.3476}{\frac{105.9}{286.07}}=0.9390=94 \% \text { purity }
\end{gathered}
$$

\section{1-[Cyclopropylethynyl]-1,2-benziodoxol-3-(1H)-one (3f):}

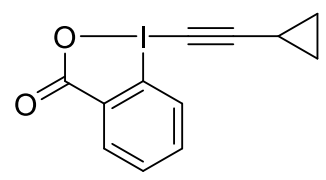

$3 f$

Synthesized following general procedure $\mathbf{B}$ starting from potassium (cyclopropylethynyl)trifluoroborate $(\mathbf{2 2})(86.0 \mathrm{mg}, 0.500 \mathrm{mmol}) .1$-[Cyclopropylethynyl]-1,2benziodoxol-3-(1H)-one (3f) (115.7 $\mathrm{mg}, 0.3555 \mathrm{mmol}, 89 \%, 96 \%$ purity) was obtained as a white solid. ${ }^{1} \mathrm{H}$ NMR $\left(400 \mathrm{MHz}, \mathrm{CDCl}_{3}\right) \delta 8.40-8.34(\mathrm{~m}, 1 \mathrm{H}), 8.18-8.12(\mathrm{~m}, 1 \mathrm{H}), 7.79-$ $7.68(\mathrm{~m}, 2 \mathrm{H}), 1.65-1.56(\mathrm{~m}, 1 \mathrm{H}), 1.05-0.97(\mathrm{~m}, 2 \mathrm{H}), 0.97-0.91(\mathrm{~m}, 2 \mathrm{H}) .{ }^{13} \mathrm{C} \mathrm{NMR}(101$ $\left.\mathrm{MHz}, \mathrm{CDCl}_{3}\right) \delta 166.7,134.7,132.4,131.6,131.5,126.2,115.9,113.4,35.1,9.8,1.1$. Spectroscopic data was consistent with the values reported in the literature. ${ }^{20}$

$$
\begin{gathered}
n(E B X)_{\text {eff }}=0.90 * 0.3950=0.3555 \mathrm{mmol} \\
p_{E B X}=\frac{0.3555}{\frac{115.7}{312.10}}=0.9590=96 \% \text { purity }
\end{gathered}
$$

\section{1-[7-Hydroxyhept-1-yn-1-yl]-1,2-benziodoxol-3-(1H)-one (3g):}

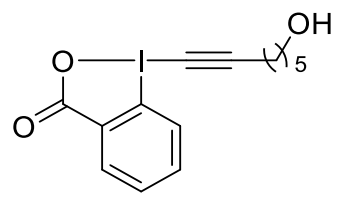

$3 \mathbf{g}$

Synthesized following general procedure B starting from potassium trifluoro(7-hydroxyhept1-yn-1-yl)borate (24) (109 mg, 0.500 mmol). 1-[7-Hydroxyhept-1-yn-1-yl]-1,2-benziodoxol-3-

\footnotetext{
${ }^{21}$ One aromatic carbon signal was not resolved, consistent with literature.
} 
(1H)-one (3g) (128.0 mg, $0.3476 \mathrm{mmol}, 87 \%, 97 \%$ purity) as a beige solid. ${ }^{1} \mathrm{H} \mathrm{NMR}(400 \mathrm{MHz}$, $\left.\mathrm{CDCl}_{3}\right) \delta 8.37(\mathrm{dd}, J=7.2,2.0 \mathrm{~Hz}, 1 \mathrm{H}), 8.20-8.13(\mathrm{~m}, 1 \mathrm{H}), 7.74(\mathrm{pd}, J=7.2,1.6 \mathrm{~Hz}, 2 \mathrm{H})$, $3.69(\mathrm{t}, J=6.1 \mathrm{~Hz}, 2 \mathrm{H}), 2.62(\mathrm{t}, J=7.0 \mathrm{~Hz}, 2 \mathrm{H}), 1.93(\mathrm{~s}, 1 \mathrm{H}, \mathrm{OH}), 1.75-1.51(\mathrm{~m}, 6 \mathrm{H}) .{ }^{13} \mathrm{C}$ NMR $\left(101 \mathrm{MHz}, \mathrm{CDCl}_{3}\right)^{22} \delta 166.9,134.8,132.4,131.6,126.4,115.7,109.6,62.5,39.5,32.1$, 28.1, 25.3, 20.6. Spectroscopic data was consistent with the values reported in the literature. ${ }^{20}$

$$
\begin{gathered}
n(E B X)_{\text {eff }}=0.88 * 0.3950=0.3476 \mathrm{mmol} \\
p_{E B X}=\frac{0.3476}{\frac{128.0}{358.17}}=0.9726=97 \% \text { purity }
\end{gathered}
$$

Alternative method used to get a pure sample of $\mathbf{3 g}$ :

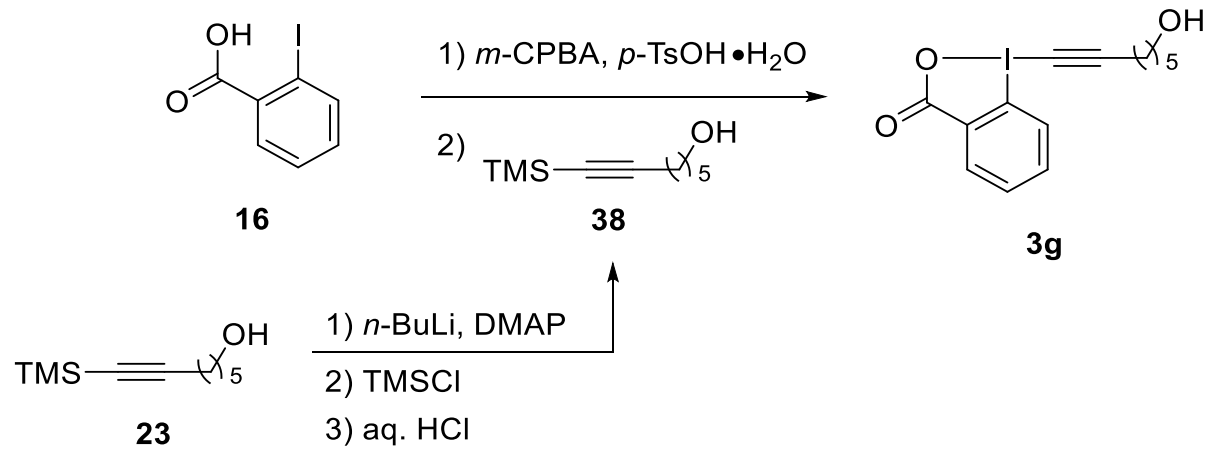

Following a reported procedure, ${ }^{20}$ an oven-dried flask was evacuated and backfilled with $\mathrm{N}_{2}$ (3x) then hept-6-yn-1-ol (23) (2.0 mL, $16 \mathrm{mmol}, 1.0$ equiv) and dry THF (42 mL) were added. The solution was cooled to $-78{ }^{\circ} \mathrm{C}$ and a solution of $n$-BuLi (14.0 mL, $35.0 \mathrm{mmol}, 2.50 \mathrm{M}, 2.2$ equiv) in hexane was added dropwise followed by a solution of 4-dimethylaminopyridine (388 $\mathrm{mg}, 3.18 \mathrm{mmol}, 0.2$ equiv) in dry THF $(6 \mathrm{~mL})$ under $\mathrm{N}_{2}$. The reaction was stirred at $-78{ }^{\circ} \mathrm{C}$ for $1 \mathrm{~h}$ then TMSCl ( $7.3 \mathrm{~mL}, 57 \mathrm{mmol}, 3.6$ equiv) was added and the mixture was stirred at $\mathrm{rt}$ for $2 \mathrm{~h}$. The reaction was quenched by the addition of $1 \mathrm{M}$ aq. $\mathrm{HCl}(20 \mathrm{~mL})$ and the mixture was stirred for $30 \mathrm{~min}$. EtOAc $(60 \mathrm{~mL})$ was added and the mixture was extracted with $3 \times 30 \mathrm{~mL}$ of EtOAc. The combined organic layers were washed with a sat. sol. of $\mathrm{NaHCO}_{3}(40 \mathrm{~mL})$ and brine $(40 \mathrm{~mL})$, dried over $\mathrm{MgSO}_{4}$, filtered and concentrated in vacuo to afford 7 (trimethylsilyl)hept-6-yn-1-ol (38) $(2.51 \mathrm{~g}, 13.6 \mathrm{mmol}, 86 \%)$ as a slightly yellow oil. ${ }^{1} \mathrm{H}$ NMR $\left(400 \mathrm{MHz}, \mathrm{CDCl}_{3}\right) \delta 3.65(\mathrm{t}, J=6.5 \mathrm{~Hz}, 2 \mathrm{H}), 2.24(\mathrm{t}, J=7.0 \mathrm{~Hz}, 2 \mathrm{H}), 1.63-1.51(\mathrm{~m}, 4 \mathrm{H}), 1.51$ $-1.43(\mathrm{~m}, 2 \mathrm{H}), 1.27(\mathrm{~s}, 1 \mathrm{H}), 0.14(\mathrm{~s}, 9 \mathrm{H})$. Spectroscopic data was consistent with the values reported in the literature. ${ }^{20}$

Following a reported procedure, ${ }^{20}$ to an oven-dried flask charged with 2-iodobenzoic acid (16) (992 mg, $4.00 \mathrm{mmol}, 1.0$ equiv) and $p-\mathrm{TsOH} \bullet \mathrm{H}_{2} \mathrm{O}(761 \mathrm{mg}, 4.00 \mathrm{mmol}, 1.0$ equiv) were added

\footnotetext{
${ }^{22}$ One aromatic carbon signal is not resolved, probably two signals overlapping at $131.6 \mathrm{ppm}$.
} 
dry DCE ( $8 \mathrm{~mL}$ ), 2,2,2-trifluoroethanol ( $8 \mathrm{~mL}$ ) and $m$-CPBA (986 mg, $4.40 \mathrm{mmol}, 1.1$ equiv). The reaction was stirred at $\mathrm{rt}$ for $1 \mathrm{~h}$ under $\mathrm{N}_{2}$ atmosphere. Then, 7-(trimethylsilyl)hept-6-yn-1ol (38) (1.03 g, $5.60 \mathrm{mmol}, 1.4$ equiv) was added and the reaction was stirred at $\mathrm{rt}$ for $16 \mathrm{~h}$. The mixture was filtered and the filtrate was concentrated in vacuo. The crude oil obtained was solubilized in DCM $(50 \mathrm{~mL})$ and a sat. sol. of $\mathrm{NaHCO}_{3}(50 \mathrm{~mL})$ was added. The mixture was vigorously stirred at $\mathrm{rt}$ for $1 \mathrm{~h}$ then extracted with $3 \times 30 \mathrm{~mL}$ of DCM. The combined organic layers were dried over $\mathrm{MgSO}_{4}$, filtered and concentrated in vacuo. The crude product was purified by column chromatography ( $\mathrm{DCM} / \mathrm{MeOH}, 98: 2$ to 95:5) to afford 1-[7-Hydroxyhept1-yn-1-yl]-1,2-benziodoxol-3-(1H)-one (3g) $(212 \mathrm{mg}, 0.591 \mathrm{mmol}, 15 \%)$ as a white solid.

\section{1-[5-Chloropent-1-yn-1-yl]-1,2-benziodoxol-3-(1H)-one (3h):}

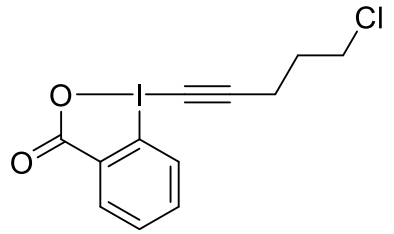

$3 h$

Synthesized following general procedure B starting from potassium (5-chloropent-1-yn-1yl)trifluoroborate (25) (104 mg, $0.500 \mathrm{mmol}$ ). 1-[5-Chloropent-1-yn-1-yl]-1,2-benziodoxol-3(1H)-one (3h) (129.9 mg, $0.3713 \mathrm{mmol}, 93 \%, 99 \%$ purity) was obtained as a white solid. ${ }^{1} \mathrm{H}$ NMR $\left(400 \mathrm{MHz}, \mathrm{CDCl}_{3}\right) \delta 8.41-8.34(\mathrm{~m}, 1 \mathrm{H}), 8.20-8.13(\mathrm{~m}, 1 \mathrm{H}), 7.81-7.69(\mathrm{~m}, 2 \mathrm{H}), 3.70$ $(\mathrm{t}, J=6.1 \mathrm{~Hz}, 2 \mathrm{H}), 2.82(\mathrm{t}, J=6.9 \mathrm{~Hz}, 2 \mathrm{H}), 2.10(\mathrm{p}, J=6.8 \mathrm{~Hz}, 2 \mathrm{H}) .{ }^{13} \mathrm{C}$ NMR $(101 \mathrm{MHz}$, $\left.\mathrm{CDCl}_{3}\right) \delta 166.7,134.9,132.6,131.7,131.6,126.3,115.7,107.2,43.3,41.3,30.8,18.0$. Spectroscopic data was consistent with the values reported in the literature. ${ }^{20}$

$$
\begin{gathered}
n(E B X)_{e f f}=0.94 * 0.3950=0.3713 \mathrm{mmol} \\
p_{E B X}=\frac{0.3713}{\frac{129.9}{348.56}}=0.9963=99 \% \text { purity }
\end{gathered}
$$

\section{1-[4-(Tosyloxy)but-1-yn-1-yl]-1,2-benziodoxol-3-(1H)-one (3i):}

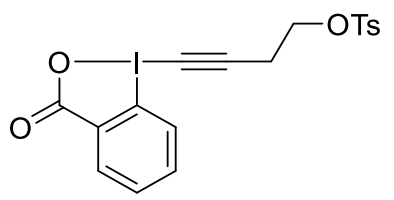

$3 \mathbf{i}$

Synthesized following general procedure B starting from potassium trifluoro(4-(tosyloxy)but1-yn-1-yl)borate (26) (112 mg, 0.500 mmol). 1-[4-(Tosyloxy)but-1-yn-1-yl]-1,2-benziodoxol3-(1H)-one (3i) (132.8 mg, $0.2706 \mathrm{mmol}, 68 \%$, 96\% purity) was obtained as a beige solid. Mp (Dec.): $120{ }^{\circ} \mathrm{C} ;{ }^{1} \mathrm{H} \mathrm{NMR}\left(400 \mathrm{MHz}, \mathrm{CDCl}_{3}\right) \delta 8.37$ (dd, $\left.J=7.4,1.7 \mathrm{~Hz}, 1 \mathrm{H}\right), 8.20$ (dd, $J=8.3$, 
$1.0 \mathrm{~Hz}, 1 \mathrm{H}), 7.83-7.77(\mathrm{~m}, 3 \mathrm{H}), 7.74(\mathrm{td}, J=7.3,1.0 \mathrm{~Hz}, 1 \mathrm{H}), 7.36-7.30(\mathrm{~m}, 2 \mathrm{H}), 4.22(\mathrm{t}, J$ $=6.2 \mathrm{~Hz}, 2 \mathrm{H}), 2.96(\mathrm{t}, J=6.2 \mathrm{~Hz}, 2 \mathrm{H}), 2.41(\mathrm{~s}, 3 \mathrm{H}) .{ }^{13} \mathrm{C} \mathrm{NMR}\left(101 \mathrm{MHz}, \mathrm{CDCl}_{3}\right) \delta 166.9$, 145.6, 135.3, 132.6, 132.5, 131.7, 131.3, 130.2, 128.1, 126.7, 115.7, 102.7, 67.0, 43.4, 21.8, 21.6. HRMS (ESI/QTOF) m/z: $[\mathrm{M}+\mathrm{H}]^{+}$Calcd for $\mathrm{C}_{18} \mathrm{H}_{16} \mathrm{IO}_{5} \mathrm{~S}^{+} 470.9758$; Found 470.9771 .

For the determination of the purity of $\mathbf{3 i}$ the signal from the EBX was changed to a triplet at $4.22 \mathrm{ppm}(2 \mathrm{H})$ due to some impurity overlapping the aromatic signals.

$$
\begin{gathered}
n(E B X)_{\text {eff }}=\frac{1.37}{2} * 0.3950=0.2706 \mathrm{mmol} \\
p_{E B X}=\frac{0.2706}{\frac{132.8}{470.28}}=0.9582=96 \% \text { purity }
\end{gathered}
$$

\section{One-pot two-step Transformations}

\subsection{Deboronative Alkynylation}

\section{General procedure C:}

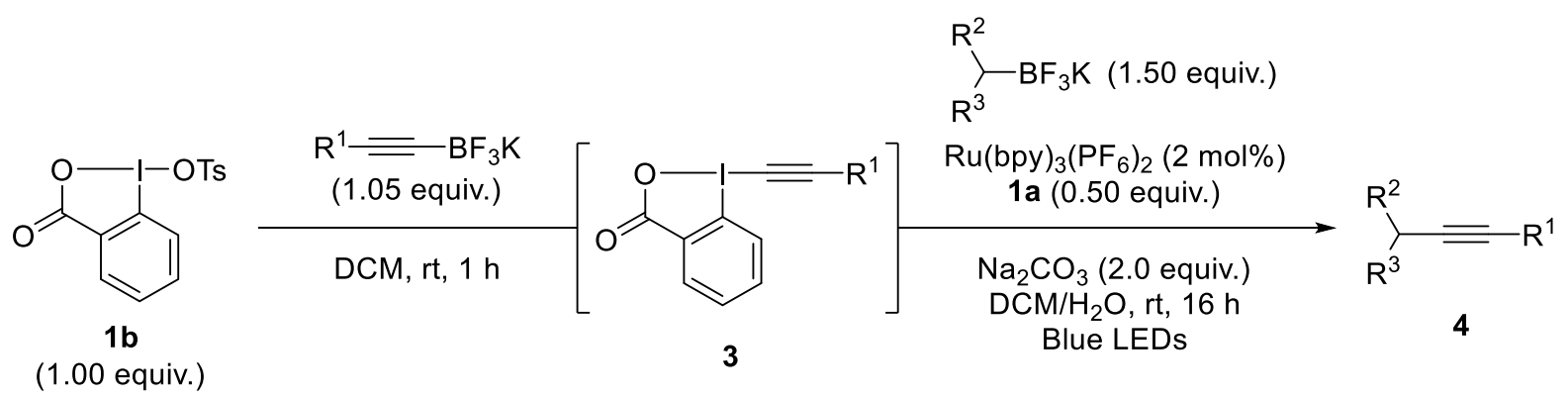

A capped oven dried microwave vial charged with 1-(p-methylbenzenesulfonyloxy)-1,2benziodoxol-3-(1H)-one (1b) (167 mg, $0.400 \mathrm{mmol}, 1.00$ equiv.) and potassium alkynyltrifluoroborate $\left(0.420 \mathrm{mmol}, 1.05\right.$ equiv.) was evacuated and backfilled with $\mathrm{N}_{2}(3 \mathrm{x})$. Dry DCM (2 mL), previously degassed with argon for $30 \mathrm{~min}$, was added under $\mathrm{N}_{2}$ and the reaction was stirred at $\mathrm{rt}$ for $1 \mathrm{~h}$. A solution of $\mathrm{Na}_{2} \mathrm{CO}_{3}$ ( $84.8 \mathrm{mg}, 0.800 \mathrm{mmol}, 2.00$ equiv.) in water $(1 \mathrm{~mL})$, previously degassed with argon for $30 \mathrm{~min}$, was added under $\mathrm{N}_{2}$ and the mixture was stirred vigorously for $5 \mathrm{~min}$.

A test tube charged with $\mathrm{Ru}(\mathrm{bpy})_{3}\left(\mathrm{PF}_{6}\right)_{2}(6.9 \mathrm{mg}, 8.0 \mu \mathrm{mol}, 0.02$ equiv. $)$, 1-hydroxy-1,2benziodoxol-3-(1H)-one (1a) $(52.8 \mathrm{mg}, \quad 0.200 \mathrm{mmol}, 0.50$ equiv.) and potassium alkyltrifluoroborate ( $0.600 \mathrm{mmol}, 1.50$ equiv.) was evacuated and backfilled with $\mathrm{N}_{2}(3 \mathrm{x})$. The biphasic solution of crude 3 was added under $\mathrm{N}_{2}(+1 \mathrm{~mL}$ of water and DCM to rinse the vial containing the solution). The reaction was stirred to $\mathrm{rt}$ under blue LEDs irradiation for $16 \mathrm{~h}$. Water $(20 \mathrm{~mL})$ was added and the mixture was extracted with DCM (3 x $20 \mathrm{~mL})$, the combined 
organic layers were dried over $\mathrm{MgSO}_{4}$, filtered and concentrated in vacuo. The crude compound was purified by column chromatography to afford $\mathbf{4}$.

But-1-yne-1,4-diyldibenzene (4a):

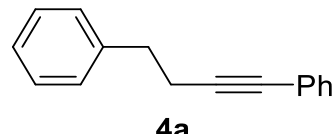

4a

Synthesized following general procedure $\mathbf{C}$ starting from potassium trifluoro(phenylethynyl)borate $\quad(\mathbf{2 a}) \quad(87.4 \quad \mathrm{mg}, \quad 0.420 \quad \mathrm{mmol})$ and potassium trifluoro(phenethyl)borate $(127.2 \mathrm{mg}, 0.6000 \mathrm{mmol})$. The crude product was purified by column chromatography (Pentane) to afford but-1-yne-1,4-diyldibenzene (4a) (48.5 mg, 0.235 mmol, 59\%) as a colorless oil. ${ }^{1} \mathrm{H}$ NMR $\left(400 \mathrm{MHz}, \mathrm{CDCl}_{3}\right) \delta 7.43-7.23(\mathrm{~m}, 10 \mathrm{H}), 2.95(\mathrm{t}, J$ $=7.5 \mathrm{~Hz}, 2 \mathrm{H}), 2.72(\mathrm{t}, J=7.5 \mathrm{~Hz}, 2 \mathrm{H}) .{ }^{13} \mathrm{C} \mathrm{NMR}\left(101 \mathrm{MHz}, \mathrm{CDCl}_{3}\right) \delta 140.8,131.7,128.7$, 128.5, 128.3, 127.8, 126.4, 124.0, 89.6, 81.4, 35.3, 21.8. Spectroscopic data was consistent with the values reported in the literature. ${ }^{18}$

\section{2-(Phenylethynyl)-2,3-dihydro-1H-indene (4b):}

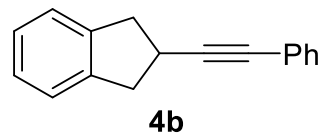

Synthesized following general procedure $\mathbf{C}$ starting from potassium trifluoro(phenylethynyl)borate (2a) $(87.4 \mathrm{mg}, 0.420 \mathrm{mmol})$ and potassium (2,3-dihydro- $1 \mathrm{H}$ inden-2-yl)trifluoroborate (37) $(134.4 \mathrm{mg}, 0.6000 \mathrm{mmol})$. The crude product was purified by column chromatography (Pentane) to afford 2-(phenylethynyl)-2,3-dihydro- $1 H$-indene (4b) (63.3 mg, $0.290 \mathrm{mmol}, 72 \%)$ as a white solid. ${ }^{1} \mathrm{H}$ NMR $\left(400 \mathrm{MHz}, \mathrm{CDCl}_{3}\right) \delta 7.46-7.40(\mathrm{~m}$, $2 \mathrm{H}), 7.33-7.27(\mathrm{~m}, 3 \mathrm{H}), 7.27-7.22(\mathrm{~m}, 2 \mathrm{H}), 7.22-7.16(\mathrm{~m}, 2 \mathrm{H}), 3.46(\mathrm{p}, J=8.5 \mathrm{~Hz}, 1 \mathrm{H})$, $3.33(\mathrm{dd}, J=15.1,7.9 \mathrm{~Hz}, 2 \mathrm{H}), 3.15(\mathrm{dd}, J=15.3,8.8 \mathrm{~Hz}, 2 \mathrm{H}) .{ }^{13} \mathrm{C} \mathrm{NMR}\left(101 \mathrm{MHz}, \mathrm{CDCl}_{3}\right)$ $\delta 142.1,131.8,128.3,127.8,126.7,124.5,123.9,93.1,80.7,40.5,30.9$. Spectroscopic data was consistent with the values reported in the literature. ${ }^{18}$

\section{Large scale synthesis of $\mathbf{4 b}$ :}

A capped oven dried microwave vial charged with 1-(p-methylbenzenesulfonyloxy)-1,2benziodoxol-3-(1H)-one (1b) (418 mg, $1.00 \mathrm{mmol}, 1.00$ equiv.) and potassium trifluoro(phenylethynyl)borate (2a) $(218 \mathrm{mg}, 1.05 \mathrm{mmol}, 1.05$ equiv.) was evacuated and backfilled with $\mathrm{N}_{2}(3 \mathrm{x})$. Dry DCM $(5 \mathrm{~mL})$, previously degassed with argon for $30 \mathrm{~min}$, was added under $\mathrm{N}_{2}$ and the reaction was stirred at $\mathrm{rt}$ for $1 \mathrm{~h}$. A solution of $\mathrm{Na}_{2} \mathrm{CO}_{3}(212 \mathrm{mg}, 2.00$ mmol, 2.00 equiv.) in water $(2.5 \mathrm{~mL})$, previously degassed with argon for $30 \mathrm{~min}$, was added under $\mathrm{N}_{2}$ and the mixture was stirred vigorously for $5 \mathrm{~min}$. 
A test tube charged with $\mathrm{Ru}(\mathrm{bpy})_{3}\left(\mathrm{PF}_{6}\right)_{2}(17.2 \mathrm{mg}, 20.0 \mu \mathrm{mol}, 0.02$ equiv. $)$, 1-hydroxy-1,2benziodoxol-3-(1H)-one (1a) (132 mg, $0.500 \mathrm{mmol}, 0.50$ equiv.) and potassium (2,3-dihydro$1 H$-inden-2-yl)trifluoroborate (37) $(336 \mathrm{mg}, 1.50 \mathrm{mmol}, 1.50$ equiv.) was evacuated and backfilled with $\mathrm{N}_{2}(3 \mathrm{x})$. The biphasic solution of crude 3 was added under $\mathrm{N}_{2}(+2.5 \mathrm{~mL}$ of water and $1 \mathrm{~mL}$ of DCM to rinse the vial containing the solution). The reaction was stirred to $\mathrm{rt}$ under blue LEDs irradiation for $16 \mathrm{~h}$. Water $(20 \mathrm{~mL})$ was added and the mixture was extracted with DCM (3 x $30 \mathrm{~mL})$, the combined organic layers were dried over $\mathrm{MgSO}_{4}$, filtered and concentrated in vacuo. The crude compound was purified by column chromatography (Pentane) to afford 2-(phenylethynyl)-2,3-dihydro- $1 H$-indene (4b) (130 mg, $0.594 \mathrm{mmol}, 59 \%)$ as a white solid.

2-((3-Methoxyphenyl)ethynyl)-2,3-dihydro-1H-indene (4c):

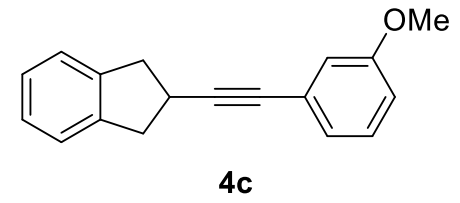

Synthesized following general procedure C starting from potassium trifluoro((3methoxyphenyl)ethynyl)borate $(\mathbf{2 7})(100 \mathrm{mg}, 0.420 \mathrm{mmol})$ and potassium (2,3-dihydro- $1 \mathrm{H}$ inden-2-yl)trifluoroborate $(37)(134 \mathrm{mg}, 0.600 \mathrm{mmol})$. The crude product was purified by column chromatography (Pentane/DCM, 1:0 to 85:15) to afford 2-((3-methoxyphenyl)ethynyl)2,3-dihydro- $1 H$-indene $(\mathbf{4 c})(72.8 \mathrm{mg}, 0.293 \mathrm{mmol}, 73 \%)$ as a colorless amorphous solid. $\mathrm{R}_{\mathrm{f}}\left(\right.$ Pentane/DCM, 85:15) = 0.33; ${ }^{1} \mathrm{H}$ NMR $\left(400 \mathrm{MHz}, \mathrm{CDCl}_{3}\right) \delta 7.26-7.22(\mathrm{~m}, 2 \mathrm{H}), 7.21-$ $7.17(\mathrm{~m}, 3 \mathrm{H}), 7.02(\mathrm{dt}, J=7.6,1.2 \mathrm{~Hz}, 1 \mathrm{H}), 6.96(\mathrm{dd}, J=2.6,1.4 \mathrm{~Hz}, 1 \mathrm{H}), 6.85(\mathrm{ddd}, J=8.4$, 2.7, $1.0 \mathrm{~Hz}, 1 \mathrm{H}), 3.80$ (s, 3H), 3.45 (p, $J=8.6 \mathrm{~Hz}, 1 \mathrm{H}), 3.33$ (dd, $J=15.1,7.9 \mathrm{~Hz}, 2 \mathrm{H}), 3.15$ $(\mathrm{dd}, J=15.3,8.8 \mathrm{~Hz}, 2 \mathrm{H}) .{ }^{13} \mathrm{C}$ NMR $\left(101 \mathrm{MHz}, \mathrm{CDCl}_{3}\right) \delta 159.4,142.1,129.4,126.7,124.9$, 124.5, 124.3, 116.5, 114.5, 93.0, 80.6, 55.4, 40.4, 30.9. HRMS (ESI/QTOF) m/z: $[\mathrm{M}+\mathrm{H}]^{+} \mathrm{Calcd}$ for $\mathrm{C}_{18} \mathrm{H}_{17} \mathrm{O}^{+} 249.1274$; Found 249.1268.

Methyl 4-((2,3-dihydro-1H-inden-2-yl)ethynyl)benzoate (4d):

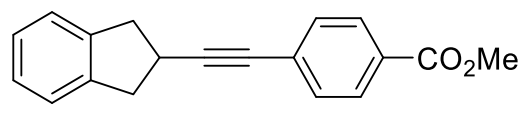

4d

Synthesized following general procedure C starting from potassium trifluoro((4(methoxycarbonyl)phenyl)ethynyl)borate (29) $(112 \mathrm{mg}, 0.420 \mathrm{mmol})$ and (2,3-dihydro- $1 \mathrm{H}$ inden-2-yl)trifluoroborate $(37)(134 \mathrm{mg}, 0.600 \mathrm{mmol})$. The crude product was purified by column chromatography (Pentane/DCM, 1:0 to 7:3) to afford methyl 4-((2,3-dihydro- $1 H$ inden-2-yl)ethynyl)benzoate (4d) $(91.8 \mathrm{mg}, 0.332 \mathrm{mmol}, 83 \%)$ as a white solid. $\mathrm{R}_{\mathrm{f}}\left(\right.$ Pentane/DCM, 7:3) = 0.33; Mp: $102{ }^{\circ} \mathrm{C} ;{ }^{1} \mathrm{H}$ NMR $\left(400 \mathrm{MHz}, \mathrm{CDCl}_{3}\right) \delta 8.06-8.00(\mathrm{~m}$, $2 \mathrm{H}), 7.56-7.50(\mathrm{~m}, 2 \mathrm{H}), 7.34-7.28(\mathrm{~m}, 2 \mathrm{H}), 7.28-7.23(\mathrm{~m}, 2 \mathrm{H}), 3.98(\mathrm{~s}, 3 \mathrm{H}), 3.53(\mathrm{p}, J=$ $8.4 \mathrm{~Hz}, 1 \mathrm{H}), 3.40(\mathrm{dd}, J=14.9,7.6 \mathrm{~Hz}, 2 \mathrm{H}), 3.21(\mathrm{dd}, J=15.3,8.5 \mathrm{~Hz}, 2 \mathrm{H}) .{ }^{13} \mathrm{C}$ NMR $(101$ 
$\left.\mathrm{MHz}, \mathrm{CDCl}_{3}\right) \delta 166.8,141.9,131.7,129.5,129.1,128.7,126.8,124.5,96.6,80.2,52.3,40.3$, 30.9. HRMS (ESI/QTOF) m/z: [M+H] ${ }^{+}$Calcd for $\mathrm{C}_{19} \mathrm{H}_{17} \mathrm{O}_{2}{ }^{+} 277.1223$; Found 277.1226.

\section{2-((4-Fluorophenyl)ethynyl)-2,3-dihydro-1H-indene (4e):}

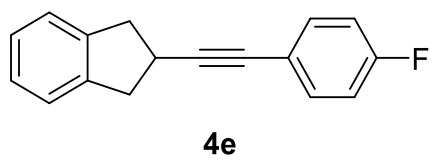

Synthesized following general procedure C starting from potassium trifluoro((4fluorophenyl)ethynyl)borate (30) (95 $\mathrm{mg}, 0.42 \mathrm{mmol}$ ) and (2,3-dihydro- $1 H$-inden-2yl)trifluoroborate $(37)(134 \mathrm{mg}, 0.600 \mathrm{mmol})$. The crude product was purified by column chromatography (Pentane/DCM, 1:0 to 85:15) to afford 2-((4-fluorophenyl)ethynyl)-2,3dihydro-1 $H$-indene (4e) $(65.2 \mathrm{mg}, 0.276 \mathrm{mmol}, 69 \%)$ as a colorless amorphous solid. $\mathrm{R}_{\mathrm{f}}\left(\right.$ Pentane/DCM; 95:5) = 0.63; ${ }^{1} \mathrm{H}$ NMR $\left(400 \mathrm{MHz}, \mathrm{CDCl}_{3}\right) \delta 7.43-7.36(\mathrm{~m}, 2 \mathrm{H}), 7.26-$ $7.22(\mathrm{~m}, 2 \mathrm{H}), 7.21-7.15(\mathrm{~m}, 2 \mathrm{H}), 7.03-6.95(\mathrm{~m}, 2 \mathrm{H}), 3.44(\mathrm{p}, J=8.6 \mathrm{~Hz}, 1 \mathrm{H}), 3.32(\mathrm{dd}, J=$ 15.0, 7.9 Hz, 2H), $3.13(\mathrm{dd}, J=15.2,8.6 \mathrm{~Hz}, 2 \mathrm{H}) .{ }^{13} \mathrm{C} \mathrm{NMR}\left(101 \mathrm{MHz}, \mathrm{CDCl}_{3}\right) \delta 162.3(\mathrm{~d}, J$ $=248.5 \mathrm{~Hz}), 142.1,133.5(\mathrm{~d}, J=8.2 \mathrm{~Hz}), 126.7,124.5,119.9$ (d, $J=3.6 \mathrm{~Hz}), 115.5$ (d, $J=21.9$ $\mathrm{Hz}), 92.8,79.7,40.4,30.8 .{ }^{19} \mathrm{~F} \mathrm{NMR}\left(376 \mathrm{MHz}, \mathrm{CDCl}_{3}\right) \delta$-112.1. HRMS (APPI/LTQ-Orbitrap) $\mathrm{m} / \mathrm{z}:[\mathrm{M}]^{+}$Calcd for $\mathrm{C}_{17} \mathrm{H}_{13} \mathrm{~F}^{+} 236.0996$; Found 236.0994.

2-(Oct-1-yn-1-yl)-2,3-dihydro-1H-indene (4f):

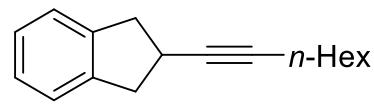

4f

Synthesized following general procedure $\mathbf{C}$ starting from potassium trifluoro(oct-1-yn-1yl)borate (19) (91 mg, $0.42 \mathrm{mmol})$ and (2,3-dihydro- $1 H$-inden-2-yl)trifluoroborate (37) (134 $\mathrm{mg}, 0.600 \mathrm{mmol}$ ). The crude product was purified by column chromatography (Pentane) to afford 2-(oct-1-yn-1-yl)-2,3-dihydro- $1 H$-indene (4f) $(34.1 \mathrm{mg}, 0.151 \mathrm{mmol}, 38 \%)$ as a colorless oil. ${ }^{1} \mathrm{H}$ NMR (400 MHz, $\left.\mathrm{CDCl}_{3}\right) \delta 7.23-7.11(\mathrm{~m}, 4 \mathrm{H}), 3.26-3.14(\mathrm{~m}, 3 \mathrm{H}), 3.04-2.92(\mathrm{~m}$, 2H), $2.17(\mathrm{td}, J=7.1,1.7 \mathrm{~Hz}, 2 \mathrm{H}), 1.54-1.44(\mathrm{~m}, 2 \mathrm{H}), 1.42-1.23(\mathrm{~m}, 6 \mathrm{H}), 0.90$ (t, $J=6.9$ $\mathrm{Hz}, 3 \mathrm{H}) .{ }^{13} \mathrm{C} \mathrm{NMR}\left(101 \mathrm{MHz}, \mathrm{CDCl}_{3}\right) \delta 142.4,126.5,124.4,83.3,80.7,40.8,31.5,30.5,29.2$, $28.7,22.7,19.0,14.2$. Spectroscopic data was consistent with the values reported in the literature. $^{18}$

((2,3-Dihydro-1H-inden-2-yl)ethynyl)triisopropylsilane (4g):

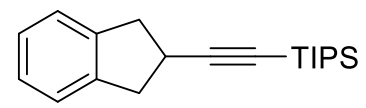


Synthesized following general procedure $\mathbf{C}$ starting from potassium trifluoro((triisopropylsilyl)ethynyl)borate (18) $(121 \mathrm{mg}, 0.420 \mathrm{mmol})$ and (2,3-dihydro- $1 \mathrm{H}$ inden-2-yl)trifluoroborate $(\mathbf{3 7})(134 \mathrm{mg}, 0.600 \mathrm{mmol})$. The crude product was purified by column chromatography (Pentane) to afford ((2,3-dihydro- $1 H$-inden-2yl)ethynyl)triisopropylsilane $\mathbf{( 4 g )}(50.8 \mathrm{mg}, 0.170 \mathrm{mmol}, 43 \%)$ as a colorless oil. ${ }^{1} \mathrm{H}$ NMR (400 $\left.\mathrm{MHz}, \mathrm{CDCl}_{3}\right) \delta 7.24-7.12(\mathrm{~m}, 4 \mathrm{H}), 3.34-3.20(\mathrm{~m}, 3 \mathrm{H}), 3.13-3.00(\mathrm{~m}, 2 \mathrm{H}), 1.13-0.97(\mathrm{~m}$, 21H). ${ }^{13} \mathrm{C} \mathrm{NMR}\left(101 \mathrm{MHz}, \mathrm{CDCl}_{3}\right) \delta 142.2,126.6,124.4,112.4,80.3,40.9,31.3,18.8,11.4$. Spectroscopic data was consistent with the values reported in the literature. ${ }^{18}$

\subsection{Thiolakynylation}

\section{General procedure D:}

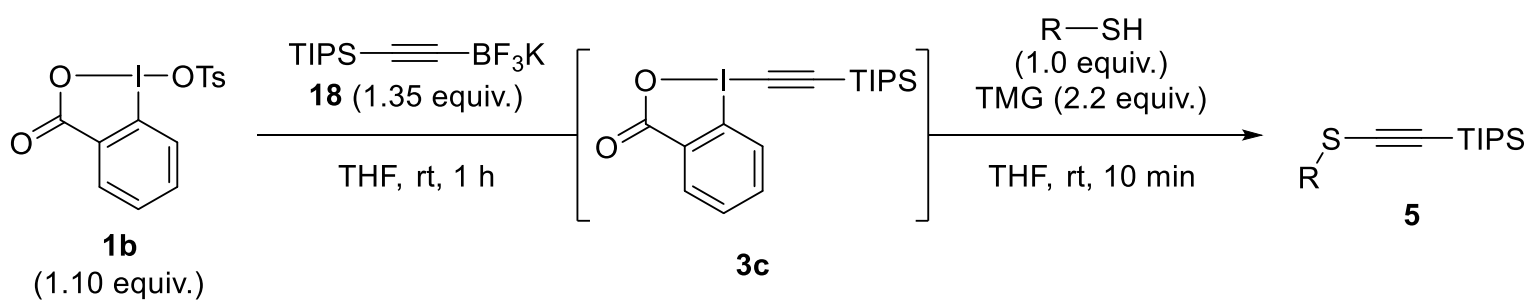

A capped oven dried microwave vial charged with 1-(p-methylbenzenesulfonyloxy)-1,2benziodoxol-3-(1H)-one (1b) (184 mg, $0.440 \mathrm{mmol}, 1.10$ equiv.) and potassium trifluoro((triisopropylsilyl)ethynyl)borate (18) (156 $\mathrm{mg}, 0.540 \mathrm{mmol}, 1.35$ equiv.) was evacuated and backfilled with $\mathrm{N}_{2}(3 \mathrm{x})$. Dry THF $(2 \mathrm{~mL})$ was added under $\mathrm{N}_{2}$ and the reaction was stirred at $\mathrm{rt}$ for $1 \mathrm{~h}$. To the mixture was added distilled 1,1,3,3-tetramethylguanidine (55 $\mu \mathrm{L}, 0.44 \mathrm{mmol}, 1.10$ equiv.) and it was stirred at $\mathrm{rt}$ for $5 \mathrm{~min}$.

To a microwave vial containing a solution of thiol $(0.40 \mathrm{mmol}, 1.00$ equiv. $)$ in dry THF $(0.5$ $\mathrm{mL}$ ) was added 1,1,3,3-tetramethylguanidine ( $55 \mu \mathrm{L}, 0.44 \mathrm{mmol}, 1.10$ equiv.). The mixture was stirred at $\mathrm{rt}$ open to air for $5 \mathrm{~min}$ then the solution of crude $3 \mathbf{c}$ was added (+ THF $(0.5 \mathrm{~mL})$ to rinse the vial). The reaction was stirred at rt open to air for $10 \mathrm{~min}$ then a sat. sol. of $\mathrm{NaHCO}_{3}$ $(15 \mathrm{~mL})$ was added. The mixture was extracted with EtOAc $(3 \times 20 \mathrm{~mL})$, the combined layers were dried over $\mathrm{MgSO}_{4}$, filtered and concentrated in vacuo. The crude product was purified by column chromatography to obtain $\mathbf{5}$.

(((2-Bromophenyl)thio)ethynyl)triisopropylsilane (5a):

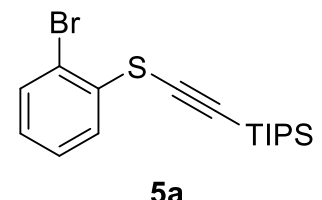

Synthesized following general procedure D starting from 2-bromothiophenol (14) $(48 \mu \mathrm{L}$, $0.40 \mathrm{mmol}$ ). The crude product was purified by column chromatography (Pentane) to afford 
(((2-bromophenyl)thio)ethynyl)triisopropylsilane (5a) (126 mg, $0.332 \mathrm{mmol}, 83 \%, 97 \%$ purity) as a colorless oil. ${ }^{1} \mathrm{H}$ NMR $\left(400 \mathrm{MHz}, \mathrm{CDCl}_{3}\right) \delta 7.76(\mathrm{dd}, J=8.0,1.5 \mathrm{~Hz}, 1 \mathrm{H}), 7.49(\mathrm{dd}, J=$ 7.9, $1.3 \mathrm{~Hz}, 1 \mathrm{H}), 7.39-7.32(\mathrm{~m}, 1 \mathrm{H}), 7.12-7.05(\mathrm{~m}, 1 \mathrm{H}), 1.18-1.12(\mathrm{~m}, 21 \mathrm{H}) .{ }^{13} \mathrm{C} \mathrm{NMR}$ $\left(101 \mathrm{MHz}, \mathrm{CDCl}_{3}\right) \delta 134.7,132.8,128.2,127.5,127.2,119.6,105.4,90.8,18.8,11.5$. Spectroscopic data was consistent with the values reported in the literature. ${ }^{23}$

Note: The impurity observed is (triisopropylsilyl)acetylene (39). ${ }^{1} \mathrm{H}$ NMR (400 $\mathrm{MHz}, \mathrm{CDCl}_{3}$ ) $\delta 2.35$ (s, 1H), 1.09 (m, 21H). ${ }^{13} \mathrm{C}$ NMR (101 MHz, $\left.\mathrm{CDCl}_{3}\right) \delta$ 94.9, 86.4, 18.6, 11.2.

Purity was determined using the $\mathrm{C} \equiv \mathrm{CH}$ signal of $\mathbf{3 9}$ and an $\mathrm{Ar} H$ signal of 5a:

$$
\begin{gathered}
p=\frac{I_{\text {product }} * M W_{\text {product }}}{\left(I_{\text {product }} * M W_{\text {product }}\right)+\left(I_{\text {byproduct }} * M W_{\text {byproduct }}\right)} \\
p=\frac{1 * 369.44}{(1 * 369.44)+(0.06 * 182.38)}=0.971=97 \% \text { purity }
\end{gathered}
$$

Methyl $N$-(tert-butoxycarbonyl)-S-((triisopropylsilyl)ethynyl)-L-cysteinate (5b):

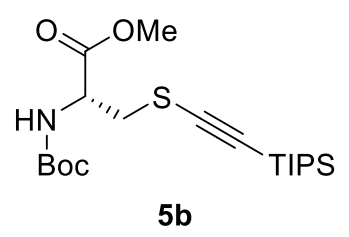

Synthesized following general procedure $\mathbf{D}$ starting from $N$-(tert-Butoxycarbonyl)- $L$-cysteine methyl ester $(97.0 \mathrm{mg}, 0.40 \mathrm{mmol})$. The crude product was purified by column chromatography (Pentane/EtOAc, 95:5) to afford methyl $N$-(tert-butoxycarbonyl)-S-((triisopropylsilyl)ethynyl)$L$-cysteinate (5b) (114 mg, $0.275 \mathrm{mmol}, 69 \%)$ as a colorless oil. ${ }^{1} \mathrm{H} \mathrm{NMR}\left(400 \mathrm{MHz}, \mathrm{CDCl}_{3}\right) \delta$ $5.45(\mathrm{~d}, J=8.4 \mathrm{~Hz}, 1 \mathrm{H}), 4.74-4.62(\mathrm{~m}, 1 \mathrm{H}), 3.78(\mathrm{~s}, 3 \mathrm{H}), 3.25(\mathrm{dd}, J=13.6,4.2 \mathrm{~Hz}, 1 \mathrm{H}), 3.13$ $(\mathrm{dd}, J=13.6,5.9 \mathrm{~Hz}, 1 \mathrm{H}), 1.44(\mathrm{~s}, 9 \mathrm{H}), 1.10-1.04(\mathrm{~m}, 21 \mathrm{H}) .{ }^{13} \mathrm{C} \mathrm{NMR}\left(101 \mathrm{MHz}, \mathrm{CDCl}_{3}\right) \delta$ $170.9,155.3,98.3,94.6,80.5,54.0,52.8,38.6,28.4$, 18.7, 11.4. Spectroscopic data was consistent with the values reported in the literature. ${ }^{23}$

\section{General procedure E:}

\footnotetext{
${ }^{23}$ R. Frei, J. Waser, J. Am. Chem. Soc. 2013, 135, 9620-9623.
} 
<smiles>O=C1OI([OH2+])c2ccccc21</smiles>

$1 \mathrm{~b}$

(1.10 equiv.)

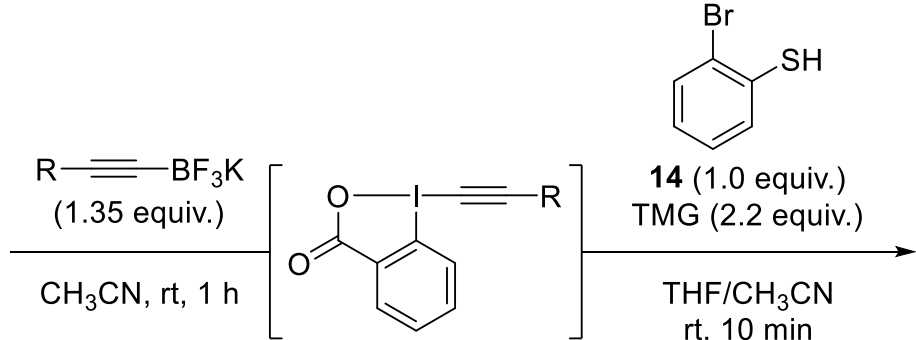

3

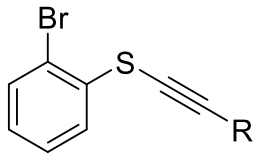

5

A capped oven dried microwave vial charged with 1-(p-methylbenzenesulfonyloxy)-1,2benziodoxol-3-(1H)-one (1b) (184 mg, $0.440 \mathrm{mmol}, 1.10$ equiv.) and potassium alkynyltrifluoroborate ( $0.54 \mathrm{mmol}, 1.35$ equiv.) was evacuated and backfilled with $\mathrm{N}_{2}(3 \mathrm{x})$. Dry $\mathrm{CH}_{3} \mathrm{CN}$ ( $2 \mathrm{~mL}$ ) was added under $\mathrm{N}_{2}$ and the reaction was stirred at $\mathrm{rt}$ for $1 \mathrm{~h}$. To the mixture was added distilled 1,1,3,3-tetramethylguanidine (55 $\mu \mathrm{L}, 0.44 \mathrm{mmol}, 1.10$ equiv.) and it was stirred at rt for $5 \mathrm{~min}$.

To a microwave vial containing a solution of 2-bromothiophenol (14) $(48 \mu \mathrm{L}, 0.40 \mathrm{mmol}, 1.00$ equiv.) in dry THF ( $0.75 \mathrm{~mL})$ was added 1,1,3,3-tetramethylguanidine $(55 \mu \mathrm{L}, 0.44 \mathrm{mmol}, 1.10$ equiv.). The mixture was stirred at $\mathrm{rt}$ open to air for $5 \mathrm{~min}$ then the solution of crude $\mathbf{3 c}$ was added $(+\mathrm{THF}(0.75 \mathrm{~mL})$ to rinse the vial). The reaction was stirred at $\mathrm{rt}$ open to air for $10 \mathrm{~min}$ then a sat. sol. of $\mathrm{NaHCO}_{3}(15 \mathrm{~mL})$ was added. The mixture was extracted with $\mathrm{Et}_{2} \mathrm{O}(3 \times 20$ $\mathrm{mL}$ ), the combined layers were dried over $\mathrm{MgSO}_{4}$, filtered and concentrated in vacuo. The crude product was purified by column chromatography to obtain $\mathbf{5}$.

\section{(2-Bromophenyl)(oct-1-yn-1-yl)sulfane (5c):}

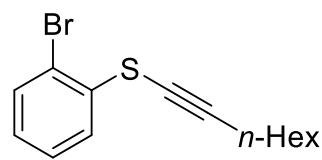

$5 c$

Synthesized following general procedure E starting from potassium trifluoro(oct-1-yn-1yl)borate (19) (117 mg, $0.540 \mathrm{mmol})$. The crude product was purified by column chromatography (Pentane) to afford (2-bromophenyl)(oct-1-yn-1-yl)sulfane (5c) (73 mg, 0.24 mmol, $61 \%)$ as a colorless oil. ${ }^{1} \mathrm{H}$ NMR $\left(400 \mathrm{MHz}, \mathrm{CDCl}_{3}\right) \delta 7.68(\mathrm{dd}, J=8.0,1.5 \mathrm{~Hz}, 1 \mathrm{H})$, $7.47(\mathrm{dd}, J=7.9,1.3 \mathrm{~Hz}, 1 \mathrm{H}), 7.37-7.31(\mathrm{~m}, 1 \mathrm{H}), 7.09-7.03(\mathrm{~m}, 1 \mathrm{H}), 2.48(\mathrm{t}, J=7.1 \mathrm{~Hz}$, 2H), $1.67-1.57(\mathrm{~m}, 2 \mathrm{H}), 1.50-1.41(\mathrm{~m}, 2 \mathrm{H}), 1.38-1.28(\mathrm{~m}, 4 \mathrm{H}), 0.91(\mathrm{t}, J=7.1 \mathrm{~Hz}, 3 \mathrm{H})$. ${ }^{13} \mathrm{C} \mathrm{NMR}\left(101 \mathrm{MHz}, \mathrm{CDCl}_{3}\right) \delta 135.7,132.7,128.1,127.1,126.9,119.3,102.1,64.5,31.4,28.7$, 28.7, 22.7, 20.5, 14.2. Spectroscopic data was consistent with the values reported in the literature. ${ }^{20}$

(2-Bromophenyl)(5-chloropent-1-yn-1-yl)sulfane (5d): 


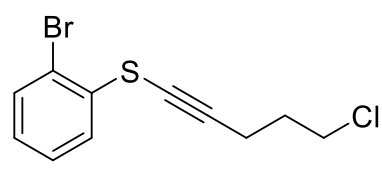

$5 d$

Synthesized following general procedure $\mathbf{E}$ starting from potassium (5-chloropent-1-yn-1yl)trifluoroborate $(\mathbf{2 5})(113 \mathrm{mg}, 0.540 \mathrm{mmol})$. The crude product was purified by column chromatography (Pentane) to afford (2-bromophenyl)(5-chloropent-1-yn-1-yl)sulfane (5d) (65 $\mathrm{mg}, 0.22 \mathrm{mmol}, 56 \%)$ as a colorless oil. ${ }^{1} \mathrm{H} \mathrm{NMR}\left(400 \mathrm{MHz}, \mathrm{CDCl}_{3}\right) \delta 7.66(\mathrm{dd}, J=8.0,1.6$ $\mathrm{Hz}, 1 \mathrm{H}), 7.48(\mathrm{dd}, J=7.9,1.3 \mathrm{~Hz}, 1 \mathrm{H}), 7.39-7.32(\mathrm{~m}, 1 \mathrm{H}), 7.11-7.04(\mathrm{~m}, 1 \mathrm{H}), 3.70(\mathrm{t}, J=$ $6.3 \mathrm{~Hz}, 2 \mathrm{H}), 2.70(\mathrm{t}, J=6.8 \mathrm{~Hz}, 2 \mathrm{H}), 2.07$ (p, $J=6.5 \mathrm{~Hz}, 2 \mathrm{H}) .{ }^{13} \mathrm{C} \mathrm{NMR}\left(101 \mathrm{MHz}, \mathrm{CDCl}_{3}\right) \delta$ $135.2,132.8,128.2,127.4,126.9,119.5,99.7,66.2,43.7,31.3,17.9$. Spectroscopic data was consistent with the values reported in the literature. ${ }^{20}$

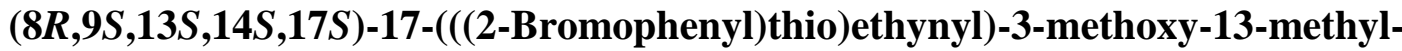
7,8,9,11,12,13,14,15,16,17-decahydro-6H-cyclopenta[a]phenanthren-17-ol (5e):

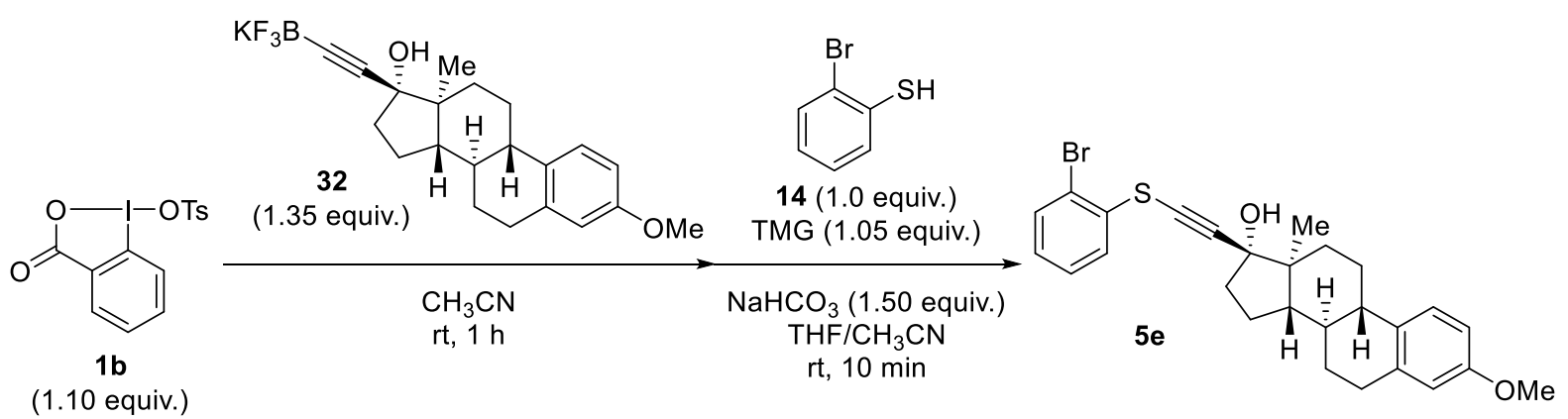

A capped oven dried microwave vial charged with 1-(p-methylbenzenesulfonyloxy)-1,2benziodoxol-3-(1H)-one (1b) (184 mg, $0.440 \mathrm{mmol}, 1.10$ equiv.) and 32 (225 mg, $0.540 \mathrm{mmol}$, 1.35 equiv.) was evacuated and backfilled with $\mathrm{N}_{2}(3 \mathrm{x})$. Dry $\mathrm{CH}_{3} \mathrm{CN}(2 \mathrm{~mL})$ was added under $\mathrm{N}_{2}$ and the reaction was stirred at $\mathrm{rt}$ for $1 \mathrm{~h}$. To the mixture was added $\mathrm{NaHCO}_{3}(50 \mathrm{mg}, 0.60$ mmol, 1.50 equiv.) and it was stirred at $\mathrm{rt}$ for $15 \mathrm{~min}$ open to air.

To a microwave vial containing a solution of 2-bromothiophenol (14) $(48 \mu \mathrm{L}, 0.40 \mathrm{mmol}, 1.00$ equiv.) in dry THF ( $0.75 \mathrm{~mL})$ was added 1,1,3,3-tetramethylguanidine $(53 \mu \mathrm{L}, 0.42 \mathrm{mmol}, 1.05$ equiv.). The mixture was stirred at rt open to air for 5 min then the solution of crude EBX was added $(+\mathrm{THF}(0.75 \mathrm{~mL})$ to rinse the vial). The reaction was stirred at $\mathrm{rt}$ open to air for $10 \mathrm{~min}$ then a sat. sol. of $\mathrm{NaHCO}_{3}(15 \mathrm{~mL})$ was added. The mixture was extracted with $\mathrm{Et}_{2} \mathrm{O}(3 \times 20$ $\mathrm{mL}$ ), the combined layers were dried over $\mathrm{MgSO}_{4}$, filtered and concentrated in vacuo. The crude product was purified by column chromatography (Toluene/DCM, 1:1) to obtain $(8 R, 9 S, 13 S, 14 S, 17 S)$-17-(((2-bromophenyl)thio)ethynyl)-3-methoxy-13-methyl-

7,8,9,11,12,13,14,15,16,17-decahydro-6H-cyclopenta[a]phenanthren-17-ol $\quad(\mathbf{5 e}) \quad(102 \quad \mathrm{mg}$, $0.205 \mathrm{mmol}, 51 \%)$ as a slightly yellow solid. $\mathrm{R}_{\mathrm{f}}\left(\right.$ Toluene/DCM, 1:1) $=0.25 ;{ }^{1} \mathrm{H}$ NMR (400 $\left.\mathrm{MHz} \mathrm{CDCl}_{3}\right) \delta 7.70(\mathrm{dd}, J=8.0,1.5 \mathrm{~Hz}, 1 \mathrm{H}), 7.50(\mathrm{dd}, J=7.9,1.3 \mathrm{~Hz}, 1 \mathrm{H}), 7.39-7.33(\mathrm{~m}$, $1 \mathrm{H}), 7.21(\mathrm{~d}, J=8.7 \mathrm{~Hz}, 1 \mathrm{H}), 7.12-7.06(\mathrm{~m}, 1 \mathrm{H}), 6.72(\mathrm{dd}, J=8.6,2.8 \mathrm{~Hz}, 1 \mathrm{H}), 6.64(\mathrm{~d}, J=$ 
$2.6 \mathrm{~Hz}, 1 \mathrm{H}), 3.78(\mathrm{~s}, 3 \mathrm{H}), 2.90-2.83(\mathrm{~m}, 2 \mathrm{H}), 2.49-2.34(\mathrm{~m}, 2 \mathrm{H}), 2.23(\mathrm{td}, J=11.2,4.2 \mathrm{~Hz}$, $1 \mathrm{H}), 2.18-2.08(\mathrm{~m}, 1 \mathrm{H}), 2.06(\mathrm{bs}, 1 \mathrm{H}), 1.95-1.72(\mathrm{~m}, 5 \mathrm{H}), 1.57-1.31(\mathrm{~m}, 4 \mathrm{H}), 0.93(\mathrm{~s}, 3 \mathrm{H})$. ${ }^{13} \mathrm{C}$ NMR $\left(101 \mathrm{MHz}, \mathrm{CDCl}_{3}\right) \delta 157.6,138.1,134.8,132.9,132.6,128.3,127.6,127.1,126.5$, 119.8, 113.9, 111.6, 104.3, 81.3, 72.1, 55.3, 50.0, 48.0, 43.7, 39.6, 39.5, 33.3, 30.0, 27.4, 26.6, 23.1, 13.0. HRMS (APPI/LTQ-Orbitrap) m/z: [M] ${ }^{+}$Calcd for $\mathrm{C}_{27} \mathrm{H}_{29} \mathrm{BrO}_{2} \mathrm{~S}^{+}$496.1066; Found 496.1062 .

\section{7-((2-Bromophenyl)thio)hept-6-yn-1-ol (5f):}<smiles>OCC#CSc1ccccc1Br</smiles>

Synthesized following general procedure $\mathbf{E}$ starting from potassium trifluoro(7-hydroxyhept1-yn-1-yl)borate (24) (118 mg, $0.540 \mathrm{mmol})$. The crude product was purified by column chromatography (Pentane/EtOAc, 95:5 to 65:35) to afford 7-((2-Bromophenyl)thio)hept-6-yn1-ol (5f) (47.3 mg, $0.158 \mathrm{mmol}, 40 \%)$ as a colorless oil. ${ }^{1} \mathrm{H} \mathrm{NMR}\left(400 \mathrm{MHz}, \mathrm{CDCl}_{3}\right) \delta 7.67$ $(\mathrm{dd}, J=8.0,1.5 \mathrm{~Hz}, 1 \mathrm{H}), 7.47(\mathrm{dd}, J=7.9,1.3 \mathrm{~Hz}, 1 \mathrm{H}), 7.37-7.31(\mathrm{~m}, 1 \mathrm{H}), 7.10-7.02$ (m, $1 \mathrm{H}), 3.66(\mathrm{t}, J=6.4 \mathrm{~Hz}, 2 \mathrm{H}), 2.50(\mathrm{t}, J=7.0 \mathrm{~Hz}, 2 \mathrm{H}), 1.71-1.57(\mathrm{~m}, 4 \mathrm{H}), 1.57-1.39(\mathrm{~m}, 3 \mathrm{H})$. ${ }^{13} \mathrm{C} \mathrm{NMR}\left(101 \mathrm{MHz}, \mathrm{CDCl}_{3}\right) \delta 135.5,132.7,128.1,127.2,126.8,119.4,101.7,64.8,62.9,32.3$, $28.5,25.2,20.5$. Spectroscopic data was consistent with the values reported in the literature. ${ }^{20}$

$\underline{\text { Alternative procedure (work-up of } \mathbf{3 g} \text { ): }}$<smiles></smiles>

$1 \mathrm{~b}$

(1.10 equiv.)

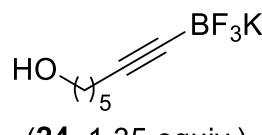

$(24,1.35$ equiv. $)$

$\mathrm{CH}_{3} \mathrm{CN}, \mathrm{rt}, 1 \mathrm{~h}$

$3 g$

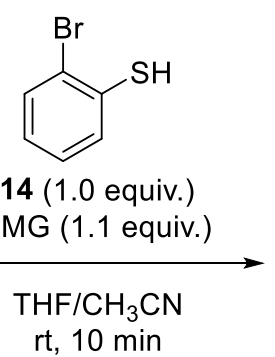

g<smiles>O[14CH2]C#CSc1ccccc1Br</smiles>

$5 f$

A capped oven dried microwave vial charged with 1-(p-methylbenzenesulfonyloxy)-1,2benziodoxol-3-(1H)-one (1b) (184 mg, $0.440 \mathrm{mmol}, 1.10$ equiv.) and trifluoro(7-hydroxyhept1-yn-1-yl)borate (24) (118 mg, $0.540 \mathrm{mmol}, 1.35$ equiv.) was evacuated and backfilled with $\mathrm{N}_{2}$ (3x). Dry $\mathrm{CH}_{3} \mathrm{CN}(4 \mathrm{~mL})$ was added under $\mathrm{N}_{2}$ and the reaction was stirred at $\mathrm{rt}$ for $1 \mathrm{~h}$. To the mixture was added a sat. sol. of $\mathrm{NaHCO}_{3}(8 \mathrm{~mL})$ and the mixture was vigorously stirred open to air for $1 \mathrm{~h}$. Water $(10 \mathrm{~mL})$ was added and the mixture was extracted with $3 \times 20 \mathrm{~mL}$ of DCM, the combined organic layers were dried over $\mathrm{MgSO}_{4}$, filtered and concentrated in vacuo. Crude $3 g$ obtained was solubilized in dry $\mathrm{CH}_{3} \mathrm{CN}(2 \mathrm{~mL})$. 
To a microwave vial containing a solution of 2-bromothiophenol (14) $(48 \mu \mathrm{L}, 0.40 \mathrm{mmol}, 1.00$ equiv.) in dry THF $(0.75 \mathrm{~mL})$ was added 1,1,3,3-tetramethylguanidine $(55 \mu \mathrm{L}, 0.44 \mathrm{mmol}, 1.10$ equiv.). The mixture was stirred at rt open to air for 5 min then was added to the solution of $\mathbf{3 g}$ ( + THF $(0.75 \mathrm{~mL})$ to rinse the vial). The reaction was stirred at $\mathrm{rt}$ open to air for $10 \mathrm{~min}$ then a sat. sol. of $\mathrm{NaHCO}_{3}(15 \mathrm{~mL})$ was added. The mixture was extracted with EtOAc $(3 \times 20 \mathrm{~mL})$, the combined layers were dried over $\mathrm{MgSO}_{4}$, filtered and concentrated in vacuo. The crude product was purified by column chromatography (Pentane/EtOAc, 95:5 to 65:35) to afford 7((2-Bromophenyl)thio)hept-6-yn-1-ol (5f) $(73.9 \mathrm{mg}, 0.247 \mathrm{mmol}, 62 \%)$ as a colorless oil.

\section{Alternative procedure (work-up of $\mathbf{3 g}$ and solvent switch to THF):}<smiles>O=C1OI(O[Na])c2ccccc21</smiles>

$1 \mathrm{~b}$

(1.10 equiv.)

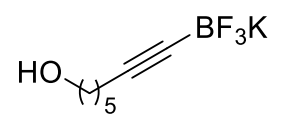

$(24,1.35$ equiv.)

$\mathrm{CH}_{3} \mathrm{CN}, \mathrm{rt}, 1 \mathrm{~h}$

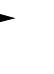

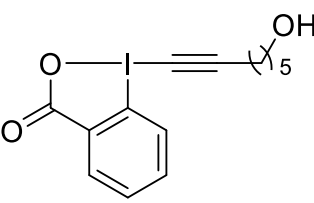

$3 \mathbf{g}$

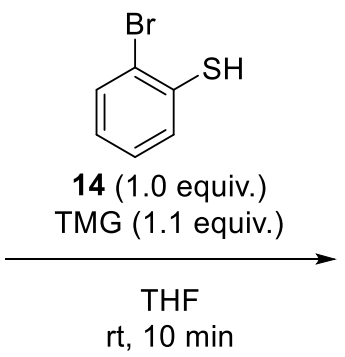

rt, $10 \mathrm{~min}$

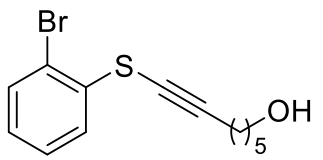

$5 f$

A capped oven dried microwave vial charged with 1-(p-methylbenzenesulfonyloxy)-1,2benziodoxol-3-(1H)-one (1b) (184 mg, $0.440 \mathrm{mmol}, 1.10$ equiv.) and trifluoro(7-hydroxyhept1-yn-1-yl)borate (24) (118 mg, $0.540 \mathrm{mmol}, 1.35$ equiv.) was evacuated and backfilled with $\mathrm{N}_{2}$ ( $3 \mathrm{x}$ ). Dry $\mathrm{CH}_{3} \mathrm{CN}(4 \mathrm{~mL})$ was added under $\mathrm{N}_{2}$ and the reaction was stirred at $\mathrm{rt}$ for $1 \mathrm{~h}$. To the mixture was added a sat. sol. of $\mathrm{NaHCO}_{3}(8 \mathrm{~mL})$ and the mixture was vigorously stirred open to air for $1 \mathrm{~h}$. Water $(10 \mathrm{~mL})$ was added and the mixture was extracted with $3 \times 20 \mathrm{~mL}$ of DCM, the combined organic layers were dried over $\mathrm{MgSO}_{4}$, filtered and concentrated in vacuo. Crude $3 \mathbf{g}$ obtained was solubilized in dry THF $(2 \mathrm{~mL})$.

To a microwave vial containing a solution of 2-bromothiophenol (14) $(48 \mu \mathrm{L}, 0.40 \mathrm{mmol}, 1.00$ equiv.) in dry THF $(0.75 \mathrm{~mL})$ was added $1,1,3,3$-tetramethylguanidine $(55 \mu \mathrm{L}, 0.44 \mathrm{mmol}, 1.10$ equiv.). The mixture was stirred at $\mathrm{rt}$ open to air for $5 \mathrm{~min}$ then was added to the solution of $\mathbf{3 g}$ (+ THF $(0.75 \mathrm{~mL})$ to rinse the vial). The reaction was stirred at $\mathrm{rt}$ open to air for $10 \mathrm{~min}$ then was concentrated in vacuo. The crude product was purified by column chromatography (Pentane/EtOAc, 95:5 to 65:35) to afford 7-((2-Bromophenyl)thio)hept-6-yn-1-ol (5f) (87.3 $\mathrm{mg}, 0.292 \mathrm{mmol}, 73 \%$ ) as a colorless oil.

Control experiment with purified $\mathbf{3 g}$ :<smiles>O=C1OI(C#C[As])c2ccccc21</smiles>

$3 g$ (1.1 equiv.)<smiles></smiles>

14 (1.0 equiv.)

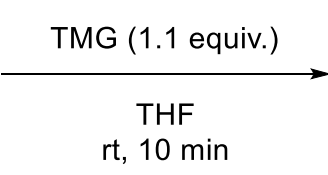

rt, $10 \mathrm{~min}$<smiles>O[14CH2]C#CSc1ccccc1Br</smiles>

$5 f$ 
Following an adapted version of a reported procedure, ${ }^{23}$ to a microwave vial containing a solution of 2-bromothiophenol (14) $(48 \mu \mathrm{L}, 0.40 \mathrm{mmol}, 1.00$ equiv. $)$ in dry THF $(0.75 \mathrm{~mL})$ was added 1,1,3,3-tetramethylguanidine $(55 \mu \mathrm{L}, 0.44 \mathrm{mmol}, 1.10$ equiv.). The mixture was stirred at $\mathrm{rt}$ open to air for $5 \mathrm{~min}$ then was added to a solution of 1-[7-Hydroxyhept-1-yn-1-yl]-1,2benziodoxol-3-(1H)-one (3g) (158 mg, $0.440 \mathrm{mmol}, 1.1$ equiv.) in dry THF (2 mL) (+ THF $(0.75 \mathrm{~mL})$ to rinse the vial). The reaction was stirred at $\mathrm{rt}$ open to air for $10 \mathrm{~min}$ then was concentrated in vacuo. The crude product was purified by column chromatography (Pentane/EtOAc, 95:5 to 65:35) to afford 7-((2-Bromophenyl)thio)hept-6-yn-1-ol (5f) (93.8 $\mathrm{mg}, 0.313 \mathrm{mmol}, 78 \%$ ) as a colorless oil.

Note: $\mathbf{3 g}$ used in this protocol was synthesized and purified according to the alternative procedure in page $\mathrm{S} 23$.

\subsection{O-VBX Formation:}

\section{(Z)-1-[2-phenyl-2-(p-tolyloxy)vinyl]-1,2-benziodoxol-3-(1H)-one (7):}<smiles>O=C1OI([O-])c2ccccc21</smiles>

1b (1.00 equiv.)

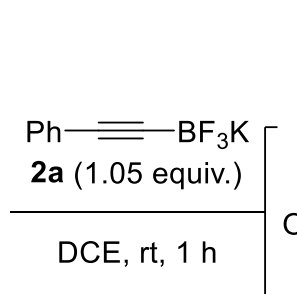

(1)

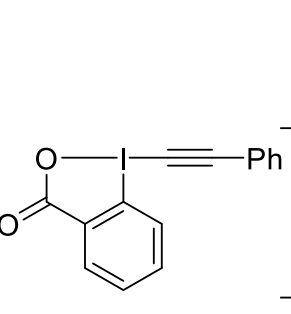

$3 a$

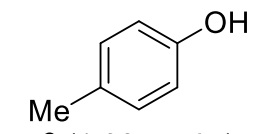

6 (1.00 equiv.) $\mathrm{Cs}_{2} \mathrm{CO}_{3}$ (2.00 equiv.)

DCE

$\mathrm{rt}, 16 \mathrm{~h}$

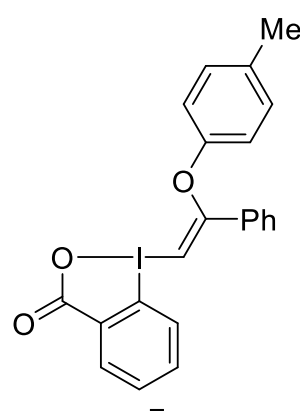

7

A capped oven dried microwave vial charged with 1-(p-methylbenzenesulfonyloxy)-1,2benziodoxol-3-(1H)-one (1b) (167 mg, $0.400 \mathrm{mmol}, 1.00$ equiv.) and potassium trifluoro(phenylethynyl)borate (2a) $(87 \mathrm{mg}, 0.420 \mathrm{mmol}, 1.05$ equiv.) was evacuated and backfilled with $\mathrm{N}_{2}(3 \mathrm{x})$. Dry DCE ( $4 \mathrm{~mL}$ ) was added under $\mathrm{N}_{2}$ and the reaction was stirred at $\mathrm{rt}$ for $1 \mathrm{~h}$. To the mixture was added $\mathrm{Cs}_{2} \mathrm{CO}_{3}(261 \mathrm{mg}, 0.800 \mathrm{mmol}, 2.0$ equiv.) and it was stirred at $\mathrm{rt}$ for $15 \mathrm{~min}$. Then, $p$-cresol (6) (43.3 $\mathrm{mg}, 0.400 \mathrm{mmol}, 1.0$ equiv.) was added and the reaction was stirred at $\mathrm{rt}$ for $16 \mathrm{~h}$. A sat. sol. of $\mathrm{NaHCO}_{3}(8 \mathrm{~mL})$ was added and the mixture was stirred vigorously for $1 \mathrm{~h}$. The mixture was extracted with DCM $(3 \times 20 \mathrm{~mL})$, the combined layers were dried over $\mathrm{MgSO}_{4}$, filtered and concentrated in vacuo. The crude product was purified by column chromatography (DCM/MeOH, 1:0 to 95:5) to obtain (Z)-1-[2-phenyl-2-(ptolyloxy)vinyl]-1,2-benziodoxol-3-(1H)-one (7) $(94 \mathrm{mg}, 0.21 \mathrm{mmol}, 52 \%)$ as a white solid. ${ }^{1} \mathrm{H}$ NMR (400 MHz, $\left.\mathrm{CDCl}_{3}\right) \delta 8.49-8.41(\mathrm{~m}, 1 \mathrm{H}), 7.68-7.56(\mathrm{~m}, 5 \mathrm{H}), 7.48-7.37(\mathrm{~m}, 3 \mathrm{H}), 7.02$ - $6.96(\mathrm{~m}, 2 \mathrm{H}), 6.77-6.72(\mathrm{~m}, 2 \mathrm{H}), 6.62(\mathrm{~s}, 1 \mathrm{H}), 2.22(\mathrm{~s}, 3 \mathrm{H}) .{ }^{13} \mathrm{C} \mathrm{NMR}\left(101 \mathrm{MHz}, \mathrm{CDCl}_{3}\right) \delta$ $166.6,165.5,153.6,133.6,133.5,133.5,133.0,131.7,131.4,130.8,130.5,129.2$, 127.8, 125.4, 
116.9, 114.5, 86.5, 20.6. Spectroscopic data was consistent with the values reported in the literature. $^{24}$

\section{Alternative procedure (work-up of 3a):}

A capped oven dried microwave vial charged with 1-(p-methylbenzenesulfonyloxy)-1,2benziodoxol-3-(1H)-one (1b) (167 mg, $0.400 \mathrm{mmol}, 1.00$ equiv.) and potassium trifluoro(phenylethynyl)borate (2a) $(87 \mathrm{mg}, 0.420 \mathrm{mmol}, 1.05$ equiv.) was evacuated and backfilled with $\mathrm{N}_{2}(3 \mathrm{x})$. Dry DCE ( $4 \mathrm{~mL}$ ) was added under $\mathrm{N}_{2}$ and the reaction was stirred at $\mathrm{rt}$ for $1 \mathrm{~h}$. To the mixture was added a sat. sol. of $\mathrm{NaHCO}_{3}(8 \mathrm{~mL})$ and the mixture was vigorously stirred open to air for $1 \mathrm{~h}$. Water $(10 \mathrm{~mL})$ was added and the mixture was extracted with $3 \times 20$ $\mathrm{mL}$ of DCM, the combined organic layers were dried over $\mathrm{MgSO}_{4}$, filtered and concentrated in vасио.

To an oven-dried microwave charged with $p$-cresol (6) (43.3 $\mathrm{mg}, 0.400 \mathrm{mmol}, 1.0$ equiv.) and $\mathrm{Cs}_{2} \mathrm{CO}_{3}(13.0 \mathrm{mg}, 40.0 \mu \mathrm{mol}, 0.1$ equiv.) was added dry DCE $(4 \mathrm{~mL})$. The mixture was stirred at $\mathrm{rt}$ for $5 \mathrm{~min}$ then crude $\mathbf{3 a}$ was added and the reaction was stirred at $\mathrm{rt}$ for $16 \mathrm{~h}$. The mixture was concentrated in vacuo. The crude product was purified by column chromatography (DCM/MeOH, 1:0 to 95:5) to obtain (Z)-1-[2-phenyl-2-(p-tolyloxy)vinyl]-1,2-benziodoxol-3(1H)-one (7) (140 mg, $0.306 \mathrm{mmol}, 76 \%)$ as a white solid.

\section{4 $\beta$-Ketoester Alkynylation}

\section{Methyl 1-oxo-2,3-dihydro-1H-indene-2-carboxylate (8):}

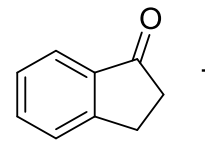

40<smiles>COC(=O)OC</smiles>

41

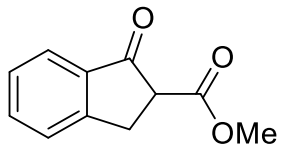

8

(2.5 equiv.)

Compound 41 was synthesized following an adapted version of a reported procedure. ${ }^{25}$ An oven dried 3-neck round bottom flask equipped with a condenser and charged with $\mathrm{NaH}(2.00 \mathrm{~g}, 49.9$ mmol, 2.2 equiv.) was evacuated and backfilled with $\mathrm{N}_{2}(3 \mathrm{x})$. The solid was washed with pentane $(3 \mathrm{x})$ then dry toluene $(94 \mathrm{~mL})$, dry DME $(11 \mathrm{~mL})$ and dimethyl carbonate $(\mathbf{4 0})$ (4.8 $\mathrm{mL}, 56.7 \mathrm{mmol}, 2.5$ equiv.) were added under $\mathrm{N}_{2}$. The mixture was heated to $80{ }^{\circ} \mathrm{C}$ and a solution of 2,3-dihydro- $1 H$-inden-1-one (40) (3.00 g, $22.7 \mathrm{mmol}, 1.0$ equiv.) in dry toluene (11 $\mathrm{mL}$ ) was added dropwise over $1 \mathrm{~h}$ under vigorous stirring. The reaction was stirred at $80{ }^{\circ} \mathrm{C}$ for $15 \mathrm{~h}$ then was allowed to cooled to rt. The mixture was diluted with $\mathrm{Et}_{2} \mathrm{O}(50 \mathrm{~mL})$ and $100 \mathrm{~mL}$ of a sat. sol. of $\mathrm{NaHCO}_{3}$ was added. The mixture was extracted with $\mathrm{Et}_{2} \mathrm{O}(3 \times 100 \mathrm{~mL})$, the

\footnotetext{
${ }^{24}$ N. Declas, J. Waser, Angew. Chem. Int. Ed. 2020, 59, 18256-18260.

${ }^{25}$ M. Rogers, C. Margot, C. Vuilleumier, B. Smith, S. Fitzgerald, M. Reiter, S. Nicolai, WO 2017005517A1, 2017. 
combined organic layers were washed with brine $(2 \times 50 \mathrm{~mL})$, dried over $\mathrm{MgSO}_{4}$, filtered and concentrated in vacuo. The crude oil was purified by column chromatography (Pentane/EtOAc, 1:0 to 85:15) to afford methyl 1-oxo-2,3-dihydro- $1 H$-indene-2-carboxylate (8) (2.92 g, 15.3 mmol, 68\%) as an orange oil which solidify in the fridge. ${ }^{1} \mathrm{H}$ NMR $\left(400 \mathrm{MHz}, \mathrm{CDCl}_{3}\right) \delta 7.78$ $(\mathrm{d}, J=7.7 \mathrm{~Hz}, 1 \mathrm{H}), 7.67-7.60(\mathrm{~m}, 1 \mathrm{H}), 7.54-7.49(\mathrm{~m}, 1 \mathrm{H}), 7.42-7.38(\mathrm{~m}, 1 \mathrm{H}), 3.80(\mathrm{~s}, 3 \mathrm{H})$, $3.74(\mathrm{dd}, J=8.3,4.1 \mathrm{~Hz}, 1 \mathrm{H}), 3.57(\mathrm{dd}, J=17.3,4.0 \mathrm{~Hz}, 1 \mathrm{H}), 3.38(\mathrm{dd}, J=17.3,8.4 \mathrm{~Hz}, 1 \mathrm{H})$. ${ }^{13} \mathrm{C} \mathrm{NMR}\left(101 \mathrm{MHz}, \mathrm{CDCl}_{3}\right) \delta 199.6,169.7,153.7,135.6,135.4,128.0,126.7,124.9,53.3$, 53.0, 30.4. Spectroscopic data was consistent with the values reported in the literature. ${ }^{26}$

\section{Methyl 2-ethynyl-1-oxo-2,3-dihydro-1H-indene-2-carboxylate (9):}

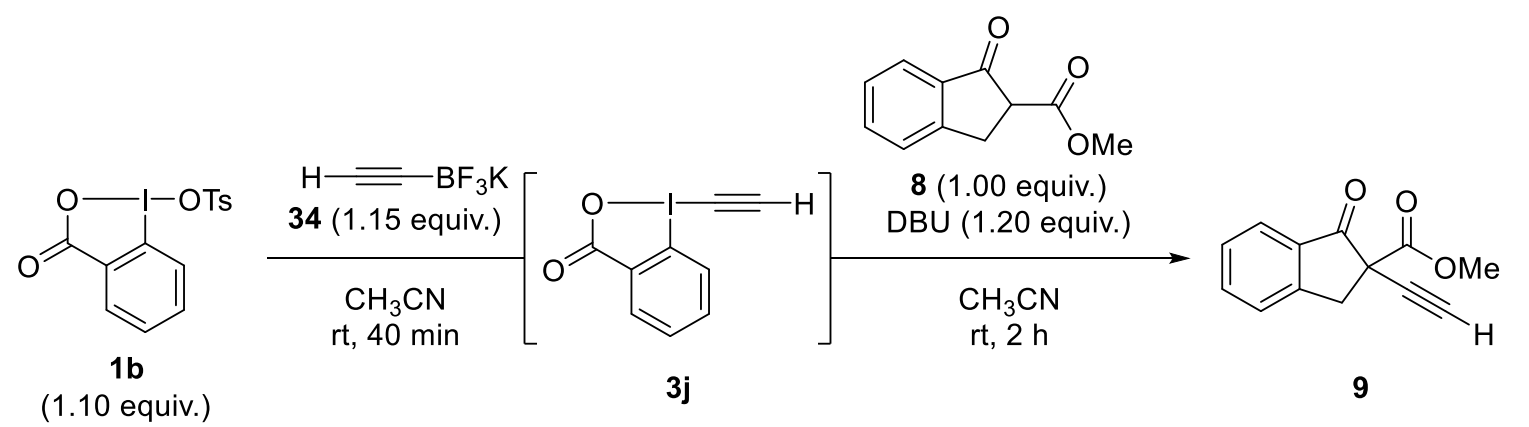

A capped oven dried microwave vial charged with 1-(p-methylbenzenesulfonyloxy)-1,2benziodoxol-3-(1H)-one (1b) (184 mg, $0.440 \mathrm{mmol}, 1.10$ equiv.) and potassium ethynyltrifluoroborate (34) $(60.7 \mathrm{mg}, 0.460 \mathrm{mmol}, 1.15$ equiv.) was evacuated and backfilled with $\mathrm{N}_{2}(3 \mathrm{x})$. Dry $\mathrm{CH}_{3} \mathrm{CN}$ (4 mL) was added under $\mathrm{N}_{2}$ and the reaction was stirred at $\mathrm{rt}$ for 40 $\min$.

To a microwave vial containing a solution of methyl 1-oxo-2,3-dihydro- $1 H$-indene-2carboxylate (8) $\left(76.1 \mathrm{mg}, 0.400 \mathrm{mmol}, 1.00\right.$ equiv.) in dry $\mathrm{CH}_{3} \mathrm{CN}(0.8 \mathrm{~mL})$ was added $\mathrm{DBU}$ ( $72 \mu \mathrm{L}, 0.48 \mathrm{mmol}, 1.20$ equiv.). The mixture was stirred at $\mathrm{rt} 5 \mathrm{~min}$ then was added to the crude solution of $\mathbf{3 j}\left(+0.2 \mathrm{~mL}\right.$ of $\mathrm{CH}_{3} \mathrm{CN}$ to rinse the vial). The reaction was stirred at $\mathrm{rt}$ for 2 $\mathrm{h}$ then $\mathrm{Et}_{2} \mathrm{O}(10 \mathrm{~mL})$ and a sat. sol. of $\mathrm{NaHCO}_{3}(20 \mathrm{~mL})$ were added. The mixture was extracted with $\mathrm{Et}_{2} \mathrm{O}(3 \times 20 \mathrm{~mL})$, the combined organic layers were dried over $\mathrm{MgSO}_{4}$, filtered and concentrated in vacuo. The crude compound was purified by column chromatography (Pentane/EtOAc, 98:2 to 85:15) to afford methyl 2-ethynyl-1-oxo-2,3-dihydro-1H-indene-2carboxylate (9) $(43.1 \mathrm{mg}, 0.201 \mathrm{mmol}, 50 \%)$ as a colorless amorphous solid. ${ }^{1} \mathrm{H}$ NMR (400 $\left.\mathrm{MHz}, \mathrm{CDCl}_{3}\right) \delta 7.85-7.80(\mathrm{~m}, 1 \mathrm{H}), 7.67(\mathrm{td}, J=7.5,1.2 \mathrm{~Hz}, 1 \mathrm{H}), 7.52-7.47(\mathrm{~m}, 1 \mathrm{H}), 7.47-$ 7.39 (m, 1H), 3.93 (d, $J=17.1 \mathrm{~Hz}, 1 \mathrm{H}), 3.80(\mathrm{~s}, 3 \mathrm{H}), 3.52$ (d, $J=17.2 \mathrm{~Hz}, 1 \mathrm{H}), 2.42(\mathrm{~s}, 1 \mathrm{H})$. ${ }^{13} \mathrm{C} \mathrm{NMR}\left(101 \mathrm{MHz}, \mathrm{CDCl}_{3}\right) \delta 196.0,168.3,152.3,136.2,133.2,128.4,126.5,126.0,80.0$,

\footnotetext{
${ }^{26}$ M. V. Vita, J. Waser, Org. Lett. 2013, 15, 3246-3249.
} 
$72.5,55.4,54.0,40.6$. Spectroscopic data was consistent with the values reported in the literature. $^{27}$

\subsection{Oxy-alkynylation of Enol Ether}

\section{(2r,4s,5r)-2,4,5,6-Tetrakis(3,6-dichloro-9H-carbazol-9-yl)isophthalonitrile (4-ClCzIPN,} 44):

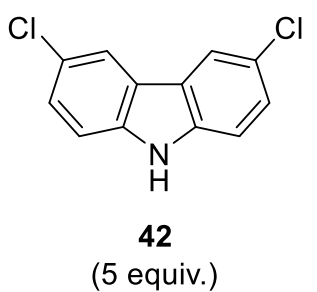

1) $\mathrm{NaH}$ (8 equiv.), $45 \mathrm{~min}$

2)<smiles>N#Cc1c(F)c(F)c(C#N)c(F)c1F</smiles>

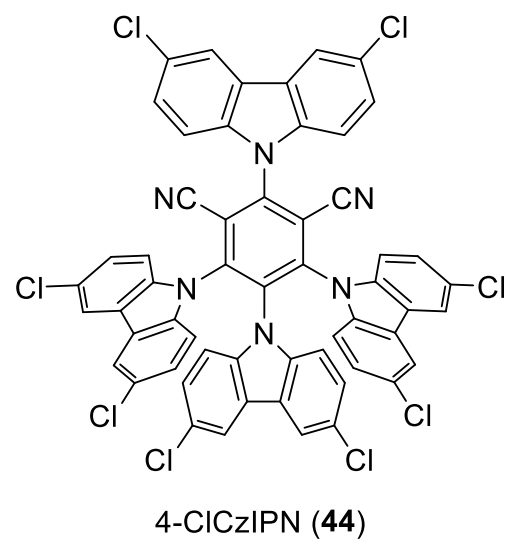

(43, 1 equiv.)

Compound 44 was synthesized following a reported procedure. ${ }^{28}$ Sodium hydride $(0.320 \mathrm{~g}$, $8.00 \mathrm{mmol}, 60 \%$ suspension in mineral oil, 8.0 equiv) was added slowly to a stirred solution of 3,6-dichloro-9H-carbazole (42) (1.96 g, $6.00 \mathrm{mmol}, 6.0$ equiv) in dry THF (20 mL) under a nitrogen atmosphere at rt. After $30 \mathrm{~min}, 2,4,5,6$-tetrafluoroisophthalonitrile (43) (200 mg, 1.00 mmol, 1.0 equiv) was added. After stirring at $\mathrm{rt}$ for $15 \mathrm{~h}, 2 \mathrm{~mL}$ water was added to the reaction mixture to quench the excess of $\mathrm{NaH}$. The resulting mixture was then concentrated under reduced pressure. A first recrystallization (Hexanes: $\mathrm{CH}_{2} \mathrm{Cl}_{2}(1: 2,80 \mathrm{~mL})$ ) of the crude product gave $900 \mathrm{mg}$ of yellow powder, then second recrystallization gave $325 \mathrm{mg}$ of brown powder. Column chromatography of the combined solid afforded (2r,4s,5r)-2,4,5,6-tetrakis $(3,6-$ dichloro-9H-carbazol-9- yl)isophthalonitrile (44) as a bright yellow crystalline solid (830 mg, $0.780 \mathrm{mmol}, 87 \%$ yield). $\mathrm{R}_{\mathrm{f}}\left(\mathrm{Hexane} / \mathrm{CH}_{2} \mathrm{Cl}_{2}, 1: 1\right)=0.25 ;{ }^{1} \mathrm{H}$ NMR (400 MHz, DMSO-d 6 ) $\delta$ $8.60(\mathrm{~d}, J=2.1 \mathrm{~Hz}, 2 \mathrm{H}), 8.15(\mathrm{~d}, J=2.1 \mathrm{~Hz}, 4 \mathrm{H}, \operatorname{ArH}), 8.08(\mathrm{~d}, J=8.8 \mathrm{~Hz}, 2 \mathrm{H}), 7.87(\mathrm{dd}, J=$ 8.8, 2.1 Hz, 2H), $7.80(\mathrm{~d}, J=2.2 \mathrm{~Hz}, 2 \mathrm{H}), 7.69(\mathrm{~d}, J=8.8 \mathrm{~Hz}, 4 \mathrm{H}), 7.46(\mathrm{~d}, J=8.8 \mathrm{~Hz}, 2 \mathrm{H})$, $7.32(\mathrm{dd}, J=8.8,2.2 \mathrm{~Hz}, 4 \mathrm{H}), 6.93(\mathrm{dd}, J=8.8,2.2 \mathrm{~Hz}, 2 \mathrm{H})$. Spectroscopic data was consistent with the values reported in the literature. ${ }^{28}$

\section{2-Ethoxy-2-methyl-4-phenylbut-3-yn-1-yl 2-iodobenzoate (11):}

\footnotetext{
27 D. Fernández González, J. P. Brand, J. Waser, Chem. - Eur. J. 2010, 16, 9457-9461.

${ }^{28}$ S. G. E. Amos, D. Cavalli, F. Le Vaillant, J. Waser, Angew. Chem. Int. Ed. 2021, 60, 23827-23834.
} 
<smiles></smiles>

$1 \mathrm{~b}$ $(1.00$ equiv. $)$

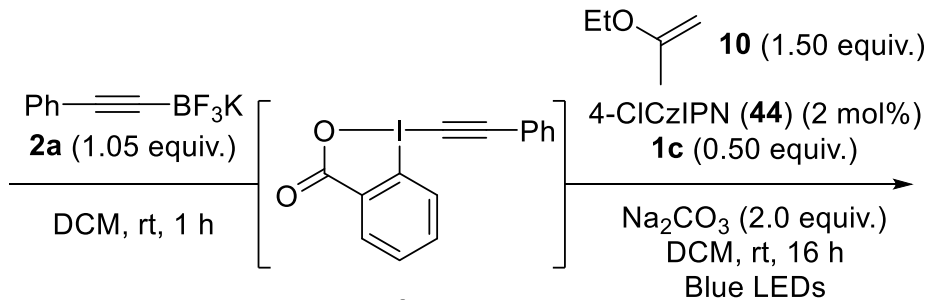

$3 a$

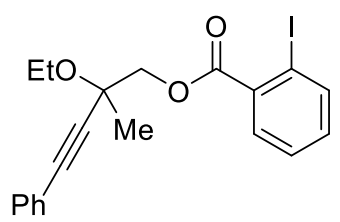

11

A capped oven dried microwave vial charged with 1-(p-methylbenzenesulfonyloxy)-1,2benziodoxol-3-(1H)-one (1b) (167 mg, $0.400 \mathrm{mmol}, 1.00$ equiv.) and potassium trifluoro(phenylethynyl)borate (2a) $(87.4 \mathrm{mg}, 0.420 \mathrm{mmol}, 1.05$ equiv.) was evacuated and backfilled with $\mathrm{N}_{2}(3 \mathrm{x})$. Dry DCM $(1.5 \mathrm{~mL})$, previously degassed by freeze-pump-thaw, was added under $\mathrm{N}_{2}$. The reaction was stirred at $\mathrm{rt}$ for $1 \mathrm{~h}$ then $\mathrm{Na}_{2} \mathrm{CO}_{3}(84.8 \mathrm{mg}, 0.800 \mathrm{mmol}, 2.00$ equiv.) was added under a flow of $\mathrm{N}_{2}$ and the mixture was stirred at $\mathrm{rt}$ for $15 \mathrm{~min}$.

An oven-dried test tube charged with 4-ClCzIPN (44) $(8.5 \mathrm{mg}, 8.0 \mu \mathrm{mol}, 0.02$ equiv.) and 1acetoxy-1,2-benziodoxol-3-(1H)-one (1c) $(61.2 \mathrm{mg}, 0.200 \mathrm{mmol}, 0.50$ equiv.) was evacuated and backfilled with $\mathrm{N}_{2}(3 \mathrm{x})$. The crude suspension of $\mathbf{3 a}$ was added (+ DCM (1.0 mL) to rinse the vial). The mixture was degassed with argon for 5 min then 2-ethoxyprop-1-ene (10) $(71 \mu \mathrm{L}$, $0.60 \mathrm{mmol}, 1.50$ equiv.) was added. The reaction was stirred at $\mathrm{rt}$ under blue LEDs irradiation for $16 \mathrm{~h}$. Then, DCM $(5 \mathrm{~mL})$ and a sat. sol. of $\mathrm{NaHCO}_{3}(20 \mathrm{~mL})$ were added and the mixture was extracted with DCM (3 x $20 \mathrm{~mL})$. The combined organic layers were dried over $\mathrm{MgSO}_{4}$, filtered and concentrated in vacuo. The crude product was dissolved in DCM and $\mathrm{Et}_{3} \mathrm{~N}(\sim 2 \mathrm{~mL})$, a solid deposit for column chromatography was prepared using silica $(\sim 3 \mathrm{~g})$. The crude was purified by column chromatography (Pentane/EtOAc, 1:0 to 95:5) to afford 2-ethoxy-2-methyl4-phenylbut-3-yn-1-yl 2-iodobenzoate (11) $(95.3 \mathrm{mg}, 0.219 \mathrm{mmol}, 55 \%)$ as a colorless oil. ${ }^{1} \mathrm{H}$ NMR (400 MHz, $\left.\mathrm{CDCl}_{3}\right) \delta 8.00(\mathrm{dd}, J=7.9,1.2 \mathrm{~Hz}, 1 \mathrm{H}), 7.90(\mathrm{dd}, J=7.8,1.7 \mathrm{~Hz}, 1 \mathrm{H}), 7.45$ $-7.41(\mathrm{~m}, 2 \mathrm{H}), 7.39$ (dd, $J=7.7,1.2 \mathrm{~Hz}, 1 \mathrm{H}), 7.34-7.29(\mathrm{~m}, 3 \mathrm{H}), 7.16(\mathrm{t}, J=7.7 \mathrm{~Hz}, 1 \mathrm{H})$, $4.59(\mathrm{~d}, J=11.2 \mathrm{~Hz}, 1 \mathrm{H}), 4.43(\mathrm{~d}, J=11.2 \mathrm{~Hz}, 1 \mathrm{H}), 3.78(\mathrm{qd}, J=7.0,0.8 \mathrm{~Hz}, 2 \mathrm{H}), 1.66(\mathrm{~s}, 3 \mathrm{H})$, $1.25(\mathrm{t}, J=7.0 \mathrm{~Hz}, 3 \mathrm{H}) .{ }^{13} \mathrm{C} \mathrm{NMR}\left(101 \mathrm{MHz}, \mathrm{CDCl}_{3}\right) \delta 166.1,141.5,134.9,132.9,131.9$, 131.4, 128.7, 128.4, 128.0, 122.4, 94.5, 87.8, 86.7, 72.4, 69.1, 60.3, 24.9, 15.9. Spectroscopic data was consistent with the values reported in the literature. ${ }^{29}$

Note: 2-ethoxyprop-1-ene (10) was eluted through a short column a basic $\mathrm{Al}_{2} \mathrm{O}_{3}$ before used.

\subsection{Decarboxylative Alkynylation}

\section{2-(Phenylethynyl)-2,3-dihydrobenzo[b][1,4]dioxine (13):}

\footnotetext{
${ }^{29}$ S. G. E. Amos, S. Nicolai, J. Waser, Chem. Sci. 2020, 11, 11274-11279.
} 


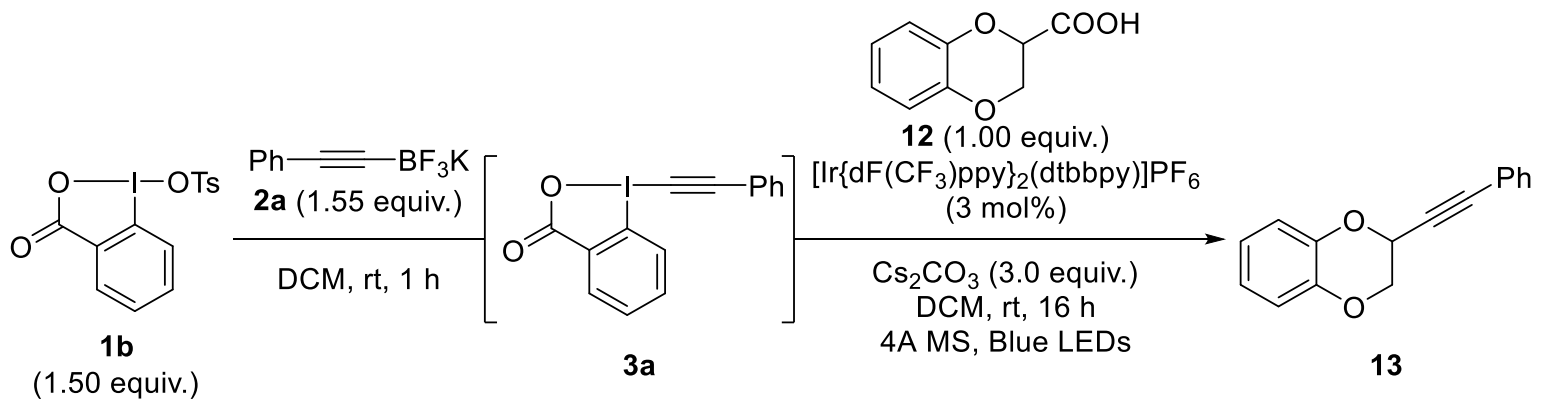

A capped oven dried microwave vial charged with 1-(p-methylbenzenesulfonyloxy)-1,2benziodoxol-3-(1H)-one (1b) (125 mg, $0.300 \mathrm{mmol}, 1.50$ equiv.) and potassium trifluoro(phenylethynyl)borate (2a) $(64.5 \mathrm{mg}, 0.310 \mathrm{mmol}, 1.55$ equiv.) was evacuated and backfilled with $\mathrm{N}_{2}(3 \mathrm{x})$. Dry DCM ( $\left.2 \mathrm{~mL}\right)$, previously degassed by freeze-pump-thaw, was added under $\mathrm{N}_{2}$. The reaction was stirred at $\mathrm{rt}$ for $1 \mathrm{~h}$ then $\mathrm{Cs}_{2} \mathrm{CO}_{3}(97.8 \mathrm{mg}, 0.300 \mathrm{mmol}, 1.50$ equiv.) was added under a flow of $\mathrm{N}_{2}$ and the mixture was stirred at $\mathrm{rt}$ for $15 \mathrm{~min}$.

An oven-dried test tube charged with $4 \AA$ molecular sieve (20 g, powder), 1,4-benzodioxane-2carboxylic acid (12) (36.4 mg, $0.200 \mathrm{mmol}, 1.00$ equiv.), [ $\left.\operatorname{Ir}\left\{\mathrm{dF}\left(\mathrm{CF}_{3}\right) \text { ppy }\right\}_{2}(\mathrm{dtbbpy})\right] \mathrm{PF}_{6}(6.8$ $\mathrm{mg}, 6.0 \mu \mathrm{mol}, 0.03$ equiv.) and $\mathrm{Cs}_{2} \mathrm{CO}_{3}(97.8 \mathrm{mg}, 0.300 \mathrm{mmol}, 1.50$ equiv.) was evacuated and backfilled with $\mathrm{N}_{2}(3 \mathrm{x})$. The crude suspension of 3a was added (+ DCM (1.0 mL) to rinse the vial). The reaction mixture was degassed with argon for 5 min then was stirred under blue LEDs irradiation for $16 \mathrm{~h}$. Then, DCM ( $5 \mathrm{~mL})$ and a sat. sol. of $\mathrm{NaHCO}_{3}(15 \mathrm{~mL})$ were added and the mixture was extracted with DCM $(3 \times 15 \mathrm{~mL})$. The combined organic layers were dried over $\mathrm{MgSO}_{4}$, filtered and concentrated in vacuo. The crude mixture was purified by column chromatography (Pentane/DCM, 95:5) to afford 2-(phenylethynyl)-2,3dihydrobenzo[b][1,4]dioxine (13) $(22.8 \mathrm{mg}, 96.5 \mu \mathrm{mol}, 48 \%)$ as a yellow oil. ${ }^{1} \mathrm{H}$ NMR (400 $\left.\mathrm{MHz}, \mathrm{CDCl}_{3}\right) \delta 7.51-7.46(\mathrm{~m}, 2 \mathrm{H}), 7.37-7.30(\mathrm{~m}, 3 \mathrm{H}), 7.00-6.95(\mathrm{~m}, 1 \mathrm{H}), 6.95-6.86(\mathrm{~m}$, $3 \mathrm{H}), 5.13(\mathrm{dd}, J=7.4,2.5 \mathrm{~Hz}, 1 \mathrm{H}), 4.45(\mathrm{dd}, J=11.3,2.5 \mathrm{~Hz}, 1 \mathrm{H}), 4.22(\mathrm{dd}, J=11.3,7.4 \mathrm{~Hz}$, 1H). ${ }^{13} \mathrm{C} \mathrm{NMR}\left(101 \mathrm{MHz}, \mathrm{CDCl}_{3}\right) \delta 142.9,142.5,132.2,129.2,128.5,122.1,122.0,121.7$, $117.8,117.4,87.9,82.6,67.6,64.7$. Spectroscopic data was consistent with the values reported in the literature. ${ }^{30}$

Note: Prior to use the $4 \AA$ molecular sieve was activated by heating it $>300{ }^{\circ} \mathrm{C}$ under vacuum for $10 \mathrm{~min}$.

\section{Alternative procedure (work-up of 3a):}

A capped oven dried microwave vial charged with 1-(p-methylbenzenesulfonyloxy)-1,2benziodoxol-3-(1H)-one (1b) (125 mg, $0.300 \mathrm{mmol}, \quad 1.50$ equiv.) and potassium trifluoro(phenylethynyl)borate (2a) $(64.5 \mathrm{mg}, 0.310 \mathrm{mmol}, 1.55$ equiv.) was evacuated and

\footnotetext{
${ }^{30}$ Q.-Q. Zhou, W. Guo, W. Ding, X. Wu, X. Chen, L.-Q. Lu, W.-J. Xiao, Angew. Chem. Int. Ed. 2015, 54, 1119611199.
} 
backfilled with $\mathrm{N}_{2}(3 \mathrm{x})$. Dry DCM ( $\left.2 \mathrm{~mL}\right)$, previously degassed by freeze-pump-thaw, was added under $\mathrm{N}_{2}$ and the reaction was stirred at $\mathrm{rt}$ for $1 \mathrm{~h}$. To the mixture was added a sat. sol. of $\mathrm{NaHCO}_{3}(8 \mathrm{~mL})$ and the mixture was vigorously stirred open to air for $1 \mathrm{~h}$. Water $(10 \mathrm{~mL})$ was added and the mixture was extracted with $3 \times 20 \mathrm{~mL}$ of DCM, the combined organic layers were dried over $\mathrm{MgSO}_{4}$, filtered and concentrated in vacuo.

An oven-dried test tube charged with $4 \AA$ molecular sieve (20 g, powder), 1,4-benzodioxane-2carboxylic acid (12) (36.4 mg, $0.200 \mathrm{mmol}, 1.00$ equiv.), [ $\left.\operatorname{Ir}\left\{\mathrm{dF}\left(\mathrm{CF}_{3}\right) \text { ppy }\right\}_{2}(\mathrm{dtbbpy})\right] \mathrm{PF}_{6}(6.8$ $\mathrm{mg}, 6.0 \mu \mathrm{mol}, 0.03$ equiv.), $\mathrm{Cs}_{2} \mathrm{CO}_{3}(97.8 \mathrm{mg}, 0.300 \mathrm{mmol}, 1.50$ equiv.) and crude $3 \mathrm{a}$ was evacuated and backfilled with $\mathrm{N}_{2}(3 \mathrm{x})$. Dry DCM (3 mL), previously degassed by freeze-pumpthaw, was added under $\mathrm{N}_{2}$ and the reaction was stirred under blue LEDs irradiation for $16 \mathrm{~h}$. The mixture was concentrated in vacuo. The crude mixture was purified by column chromatography (Pentane/DCM, 95:5) to afford 2-(phenylethynyl)-2,3dihydrobenzo[b][1,4]dioxine (13) $(40.2 \mathrm{mg}, 0.170 \mathrm{mmol}, 85 \%)$ as a yellow oil.

\subsection{Synthesis of 1,2-Dithioalkene}

\section{(Z)-(1-Phenylethene-1,2-diyl)bis((2-bromophenyl)sulfane) (15)}

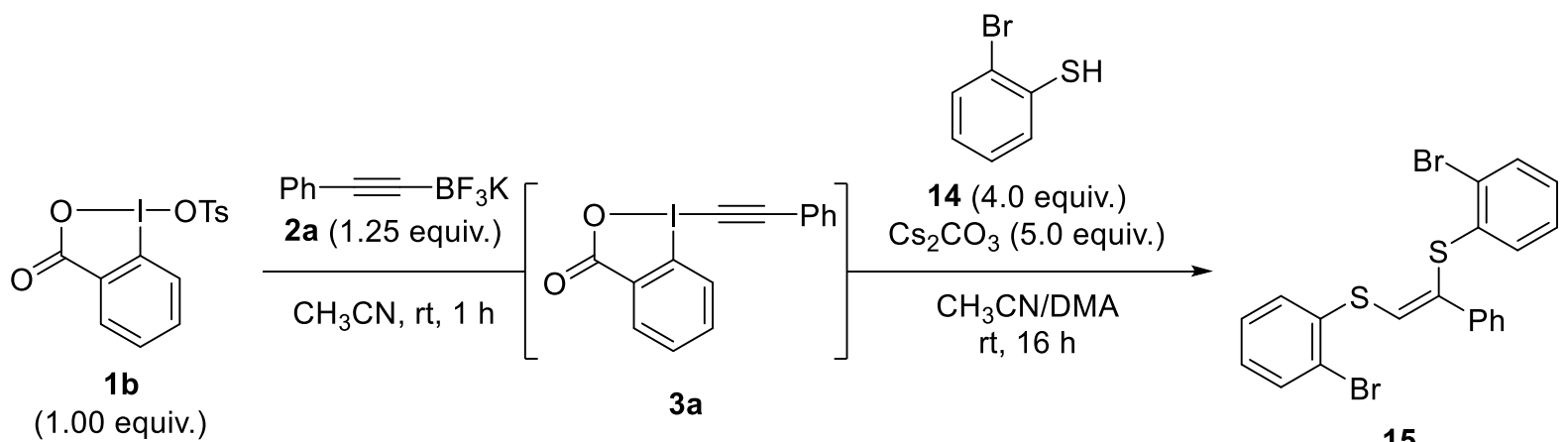

A capped oven dried microwave vial charged with 1-( $p$-methylbenzenesulfonyloxy)-1,2benziodoxol-3-(1H)-one (1b) $(83.6 \mathrm{mg}, \quad 0.200 \mathrm{mmol}, 1.00$ equiv.) and potassium trifluoro(phenylethynyl)borate (2a) $(52.0 \mathrm{mg}, 0.250 \mathrm{mmol}, 1.25$ equiv.) was evacuated and backfilled with $\mathrm{N}_{2}(3 \mathrm{x})$. Dry $\mathrm{CH}_{3} \mathrm{CN}$ (1 mL), previously degassed with argon for $30 \mathrm{~min}$, was added under $\mathrm{N}_{2}$ and the reaction was stirred at $\mathrm{rt}$ for $1 \mathrm{~h}$. Then, $\mathrm{Cs}_{2} \mathrm{CO}_{3}(65.2 \mathrm{mg}, 0.20 \mathrm{mmol}$, 1.00 equiv.) was added and the mixture was stirred at $\mathrm{rt}$ for $15 \mathrm{~min}$.

A capped oven dried microwave vial charged with $\mathrm{Cs}_{2} \mathrm{CO}_{3}(261 \mathrm{mg}, 0.800 \mathrm{mmol}, 4.00$ equiv.) was evacuated and backfilled with $\mathrm{N}_{2}(3 \mathrm{x})$. Dry DMA $(0.75 \mathrm{~mL})$, previously degassed with argon for $30 \mathrm{~min}$, and 2-bromothiophenol (14) $(96 \mu \mathrm{L}, 0.80 \mathrm{mmol}, 4.00$ equiv.) was added under $\mathrm{N}_{2}$. The solution of crude $3 \mathbf{a}$ was added $\left(+0.75 \mathrm{~mL}\right.$ of DMA to rinse the vial) under $\mathrm{N}_{2}$ and the reaction was stirred at $\mathrm{rt}$ for $16 \mathrm{~h}$. Then, water $(10 \mathrm{~mL})$ and a sat. sol. of $\mathrm{NaHCO}_{3}(5$ $\mathrm{mL})$ were added and the mixture was extracted with EtOAc $(3 \times 15 \mathrm{~mL})$. The combined organic layers were washed with brine $(2 \times 15 \mathrm{~mL})$, dried over $\mathrm{MgSO}_{4}$, filtered and concentrated in vacuo. The crude mixture was purified by preparative TLC (Pentane/DCM, 95:5) to afford (Z)- 
(1-phenylethene-1,2-diyl)bis((2-bromophenyl)sulfane) (15) $(63.0 \mathrm{mg}, 0.132 \mathrm{mmol}, 66 \%)$ as a colorless oil. $\mathrm{R}_{\mathrm{f}}\left(\right.$ Pentane/DCM, 95:5) = 0.2; ${ }^{1} \mathrm{H} \mathrm{NMR}\left(400 \mathrm{MHz}, \mathrm{CDCl}_{3}\right) \delta 7.64(\mathrm{dd}, J=8.0$, $1.4 \mathrm{~Hz}, 1 \mathrm{H}), 7.60-7.54(\mathrm{~m}, 3 \mathrm{H}), 7.49(\mathrm{dd}, J=7.9,1.3 \mathrm{~Hz}, 1 \mathrm{H}), 7.33(\mathrm{td}, J=7.6,1.4 \mathrm{~Hz}, 1 \mathrm{H})$, $7.30-7.21(\mathrm{~m}, 4 \mathrm{H}), 7.20-7.14(\mathrm{~m}, 1 \mathrm{H}), 7.13-7.04(\mathrm{~m}, 2 \mathrm{H}), 6.97-6.92(\mathrm{~m}, 1 \mathrm{H}) .{ }^{13} \mathrm{C} \mathrm{NMR}$ $\left(101 \mathrm{MHz}, \mathrm{CDCl}_{3}\right) \delta 138.3,136.2,136.2,135.9,133.7,133.1,132.0,130.7,129.1,128.9,128.7$, 128.3, 128.2, 127.8, 127.1, 126.8, 125.9, 122.8. HRMS (nanochip-ESI/LTQ-Orbitrap) m/z: $[\mathrm{M}+\mathrm{H}]^{+}$Calcd for $\mathrm{C}_{20} \mathrm{H}_{15} \mathrm{Br}_{2} \mathrm{~S}_{2}{ }^{+} 476.8976$; Found 476.8967 .

\section{Crystal structure of TsOBX (1b)}
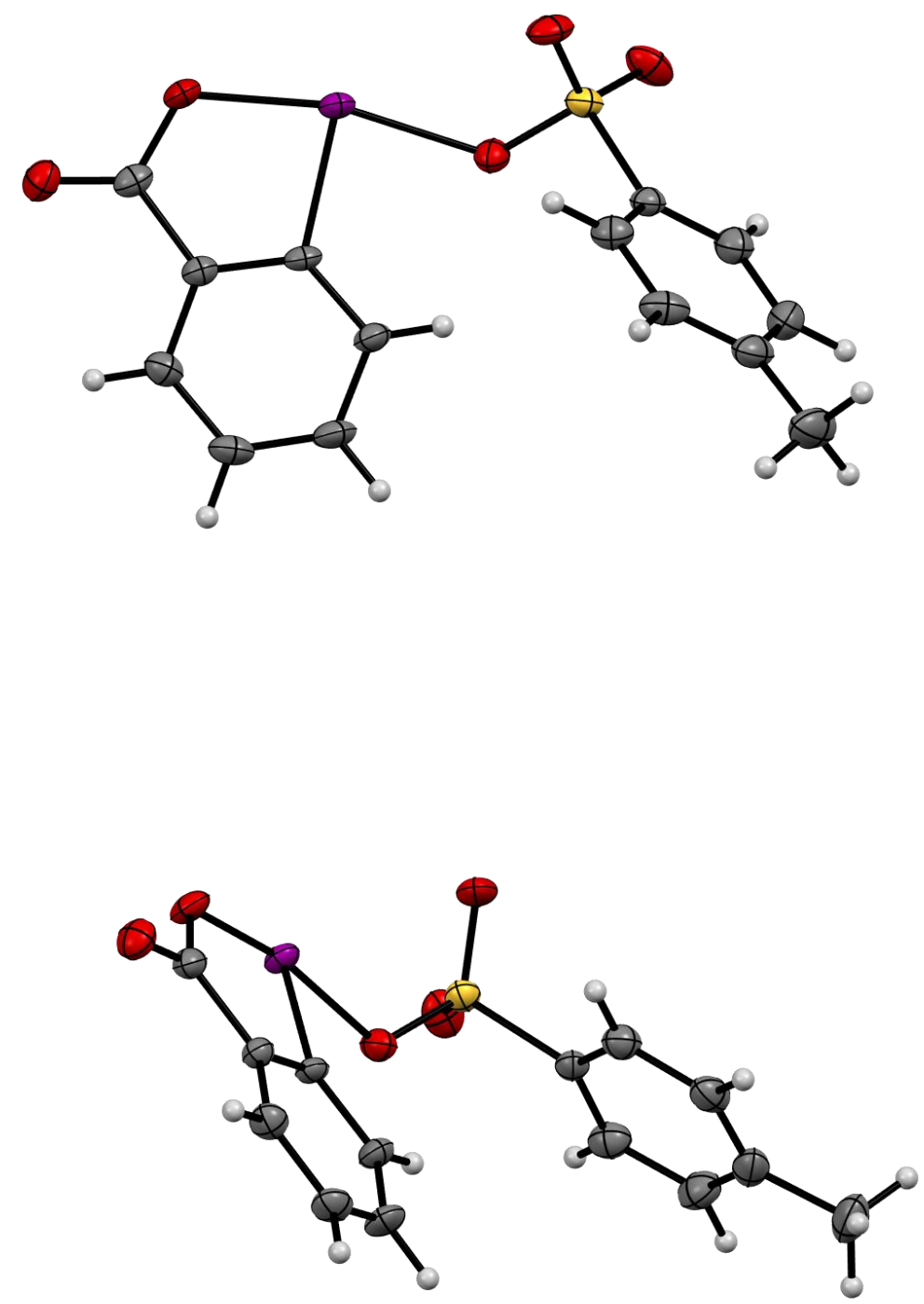

Figure S1: Ellipsoid plot (probability level 50\%) of TsOBX (1b) 


\begin{tabular}{|c|c|}
\hline Compound & $1 b$ \\
\hline Formula & $\mathrm{C}_{14} \mathrm{H}_{11} \mathrm{IO}_{5} \mathrm{~S}$ \\
\hline$D_{\text {calc. }} / \mathrm{g} \mathrm{cm}^{-3}$ & 1.934 \\
\hline$\mu / \mathrm{mm}^{-1}$ & 2.393 \\
\hline Formula Weight & 418.19 \\
\hline Colour & colourless \\
\hline Shape & plate \\
\hline Size $/ \mathrm{mm}^{3}$ & $0.36 \times 0.15 \times 0.03$ \\
\hline$T / \mathrm{K}$ & $140.00(10)$ \\
\hline Crystal System & monoclinic \\
\hline Space Group & $P 2_{1} / c$ \\
\hline$a / \AA ̊$ & $13.7321(6)$ \\
\hline$b / \AA$ & $6.4271(2)$ \\
\hline$c / \AA$ & $16.5260(6)$ \\
\hline$\left.\alpha\right|^{\circ}$ & 90 \\
\hline$\beta /^{\circ}$ & $100.000(3)$ \\
\hline$\left.\gamma\right|^{\circ}$ & 90 \\
\hline $\mathrm{V} / \AA^{3}$ & $1436.40(9)$ \\
\hline$Z$ & 4 \\
\hline$Z^{\prime}$ & 1 \\
\hline Wavelength/Å & 0.71073 \\
\hline Radiation type & $\operatorname{Mo} K \alpha$ \\
\hline$\Theta_{\min } /^{\circ}$ & 2.688 \\
\hline$\Theta_{\max } /^{\circ}$ & 35.049 \\
\hline Measured Refl's. & 27470 \\
\hline Indep't Refl's & 5958 \\
\hline Refl's I $\geq 2 \sigma(I)$ & 4547 \\
\hline$R_{\text {int }}$ & 0.0420 \\
\hline Parameters & 191 \\
\hline Restraints & 0 \\
\hline Largest Peak/e $\AA^{-3}$ & 1.534 \\
\hline Deepest Hole/e $\AA^{-3}$ & -1.331 \\
\hline GooF & 1.066 \\
\hline$w R_{2}$ (all data) & 0.0728 \\
\hline$w R_{2}$ & 0.0645 \\
\hline$R_{1}$ (all data) & 0.0556 \\
\hline$R_{1}$ & 0.0343 \\
\hline
\end{tabular}

Crystals were grown using a batch of TsOBX (1b) which upon synthesis was immediately stored in a glovebox filled with $\mathrm{N}_{2}$. Recrystallization of $\mathbf{1 b}(150 \mathrm{mg}, 0.359$ mmol) from this batch was performed in dry boiling DCE (13 mL) under $\mathrm{N}_{2}$ using oven-dried glassware outside of the glovebox. The compound did not seem to be soluble and the suspension was left to cool slowly over $16 \mathrm{~h}$. Some small crystals formed on the side of the flask and were collected.

Analysis of the crystal: A suitable crystal with dimensions $0.36 \times 0.15 \times 0.03 \mathrm{~mm}^{3}$ was selected and mounted on a SuperNova, Dual, $\mathrm{Cu}$ at home/near, Atlas diffractometer. The crystal was kept at a steady $T=$ 140.00(10) K during data collection. The structure was solved with the ShelXT 2018/2 (Sheldrick, 2015) solution program using dual methods and by using Olex2 (Dolomanov et al., 2009) as the graphical interface. The model was refined with ShelXL 2018/3 (Sheldrick, 2015) using full matrix least squares minimisation on $\boldsymbol{F}^{\mathbf{2}}$.

Supplementary crystallographic data for this compound have been deposited at Cambridge Crystallographic Data Centre (CCDC 2117886) and can be obtained free of charge via www.ccdc.cam.ac.uk/data_request/cif.

\section{NMR Spectra}


${ }^{1} \mathrm{H}$ NMR (400 MHz, DMSO-d 6 ) of compound $\mathbf{1 b}$ :

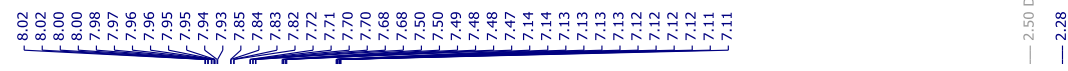<smiles>O=C1OCc2ccccc21</smiles>

$1 \mathrm{~b}$

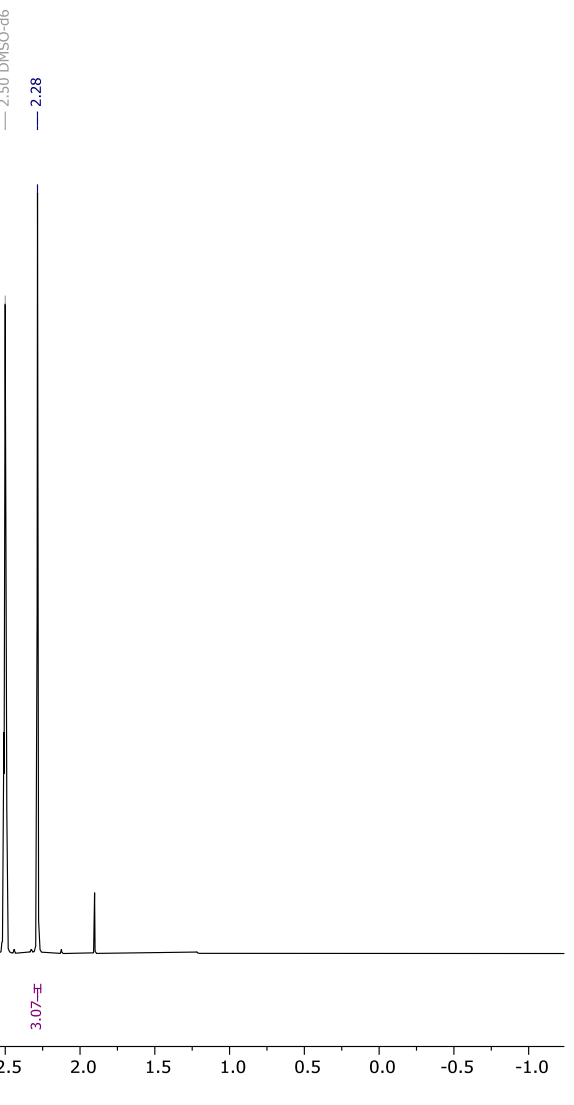

${ }^{13} \mathrm{C}$ NMR (101 MHz, DMSO-d 6 ) of compound $\mathbf{1 b}$ :

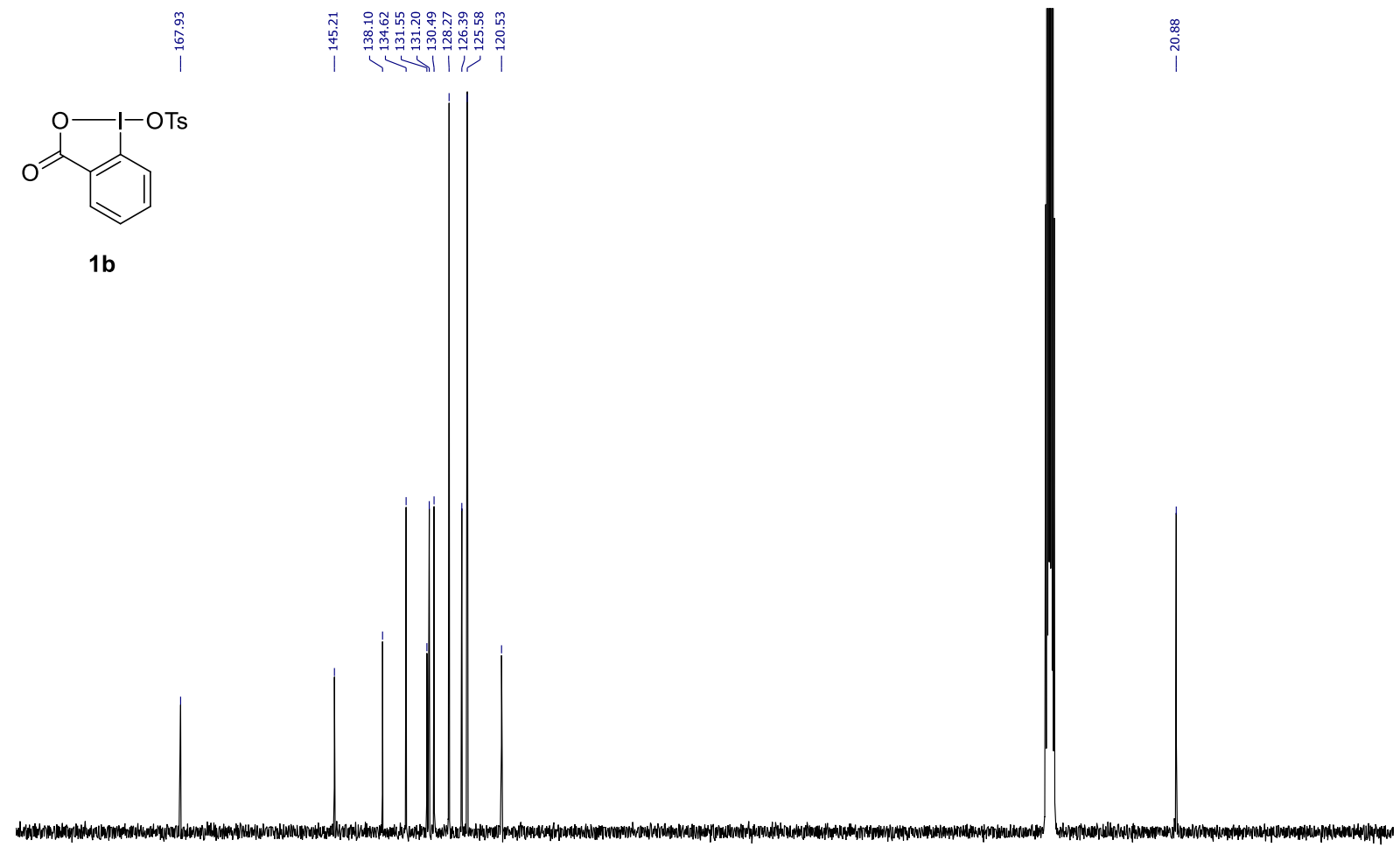

$\begin{array}{rllllllllllllllllllllllll}\mid & 190 & 180 & 170 & 160 & 150 & 140 & 130 & 120 & 110 & 100 & 90 & 80 & 70 & 60 & 50 & 40 & 30 & 20 & 10 & 0 & -1\end{array}$ 
${ }^{1} \mathrm{H} \mathrm{NMR}\left(400 \mathrm{MHz}, \mathrm{CDCl}_{3}\right)$ of compound 1c:

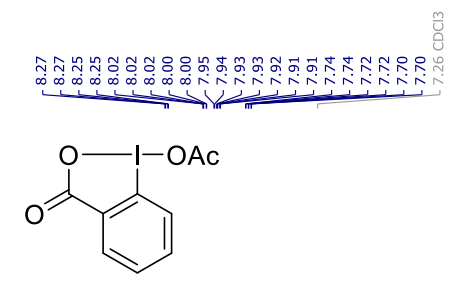

1c

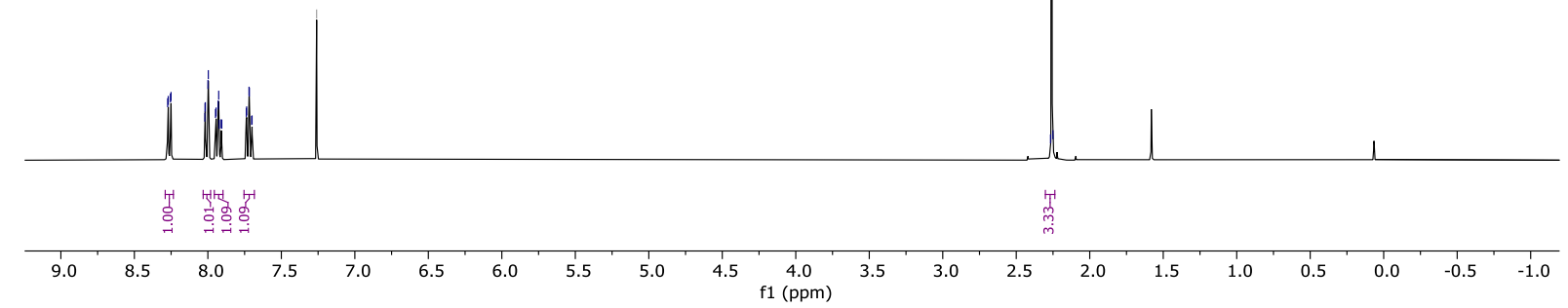

${ }^{1} \mathrm{H}$ NMR (400 MHz, $\mathrm{CDCl}_{3}$ ) of compound $\mathbf{1 d}$ :

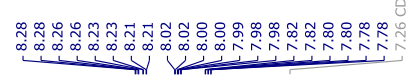

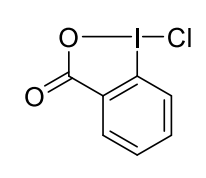

1d

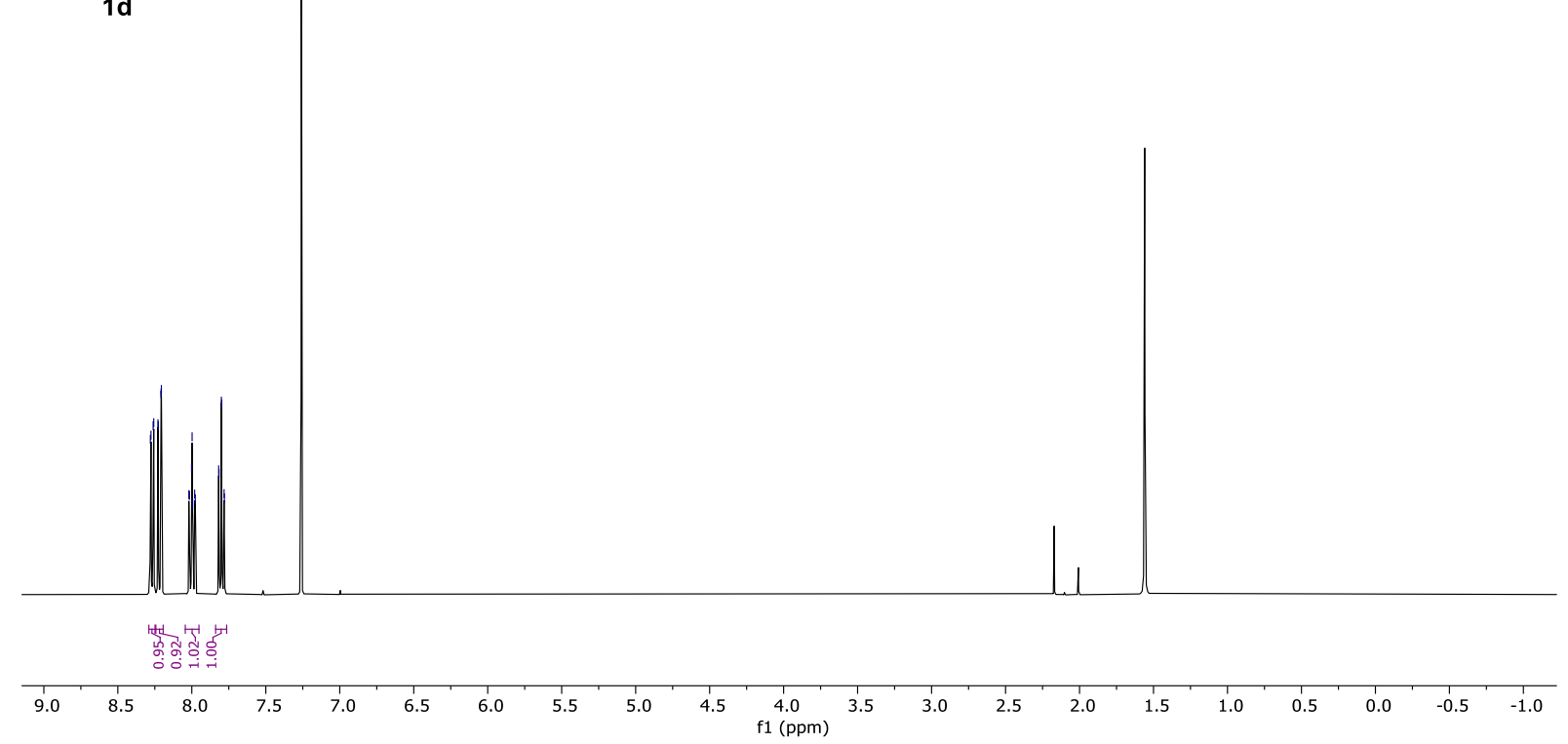


${ }^{13} \mathrm{C}$ NMR (101 MHz, $\mathrm{CDCl}_{3}$ ) of compound $\mathbf{1 d :}$

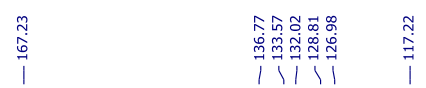

(1)

$1 d$

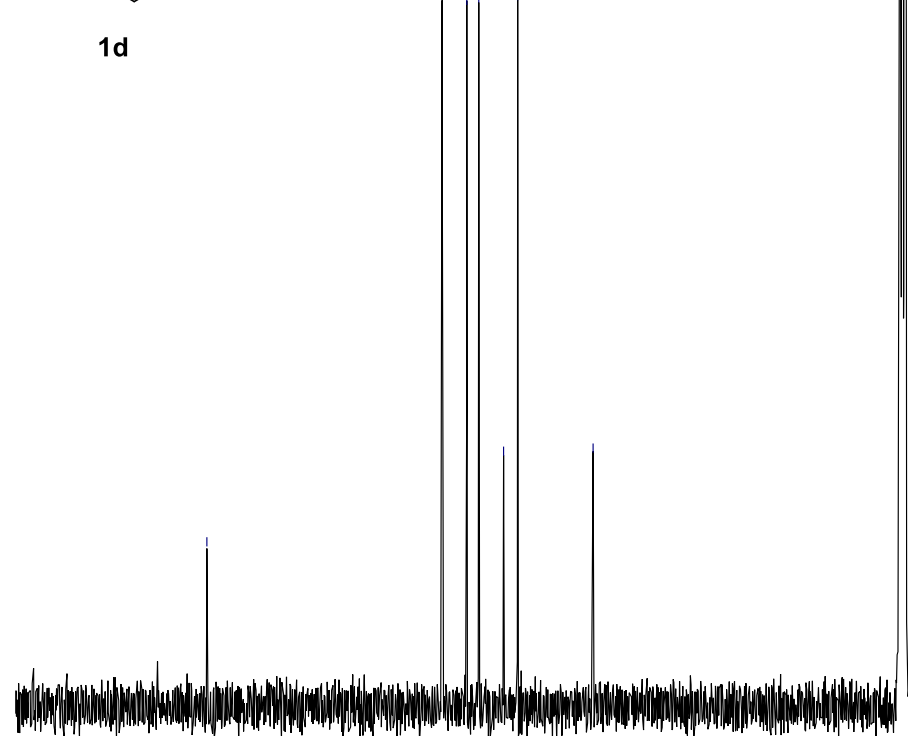

\begin{tabular}{lllllllllllllllllllll}
\hline 190 & 180 & 170 & 160 & 150 & 140 & 130 & 120 & 110 & 100 & $\begin{array}{c}1 \\
1\end{array}$ & 80 & 70 & 60 & 50 & 40 & 30 & 20 & 10 & 0 & -10
\end{tabular}

${ }^{1} \mathrm{H}$ NMR (400 MHz, acetone- $\mathrm{d}_{6}$ ) of compound 2a:

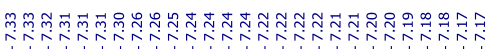

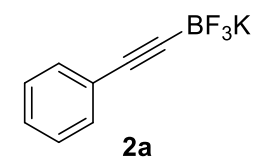

$2 a$
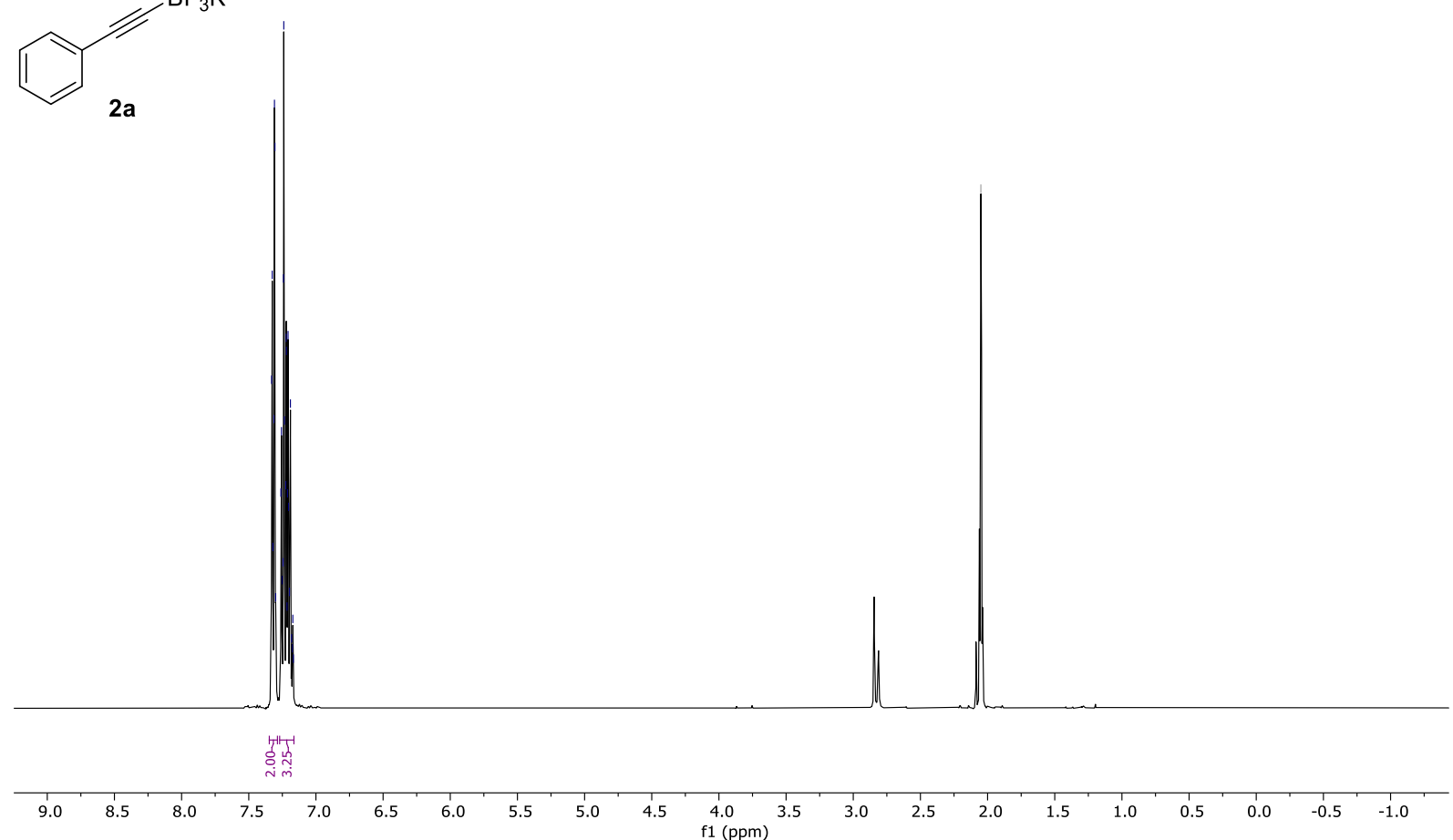
${ }^{13} \mathrm{C}$ NMR (101 MHz, acetone- $\mathrm{d}_{6}$ ) of compound 2a:
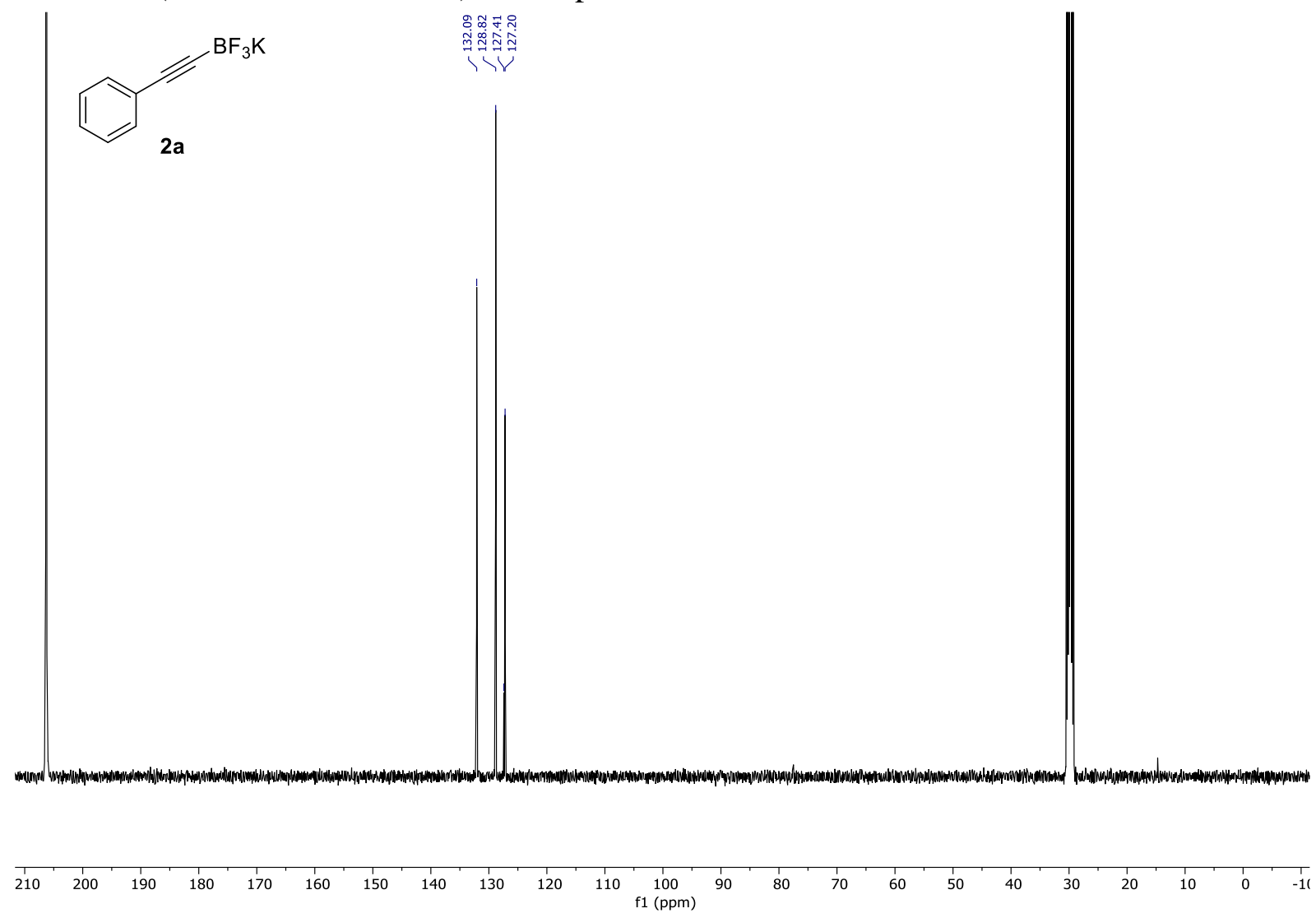

${ }^{19}$ F NMR (376 MHz, acetone- $\mathrm{d}_{6}$ ) of compound $\mathbf{2 a}$ :

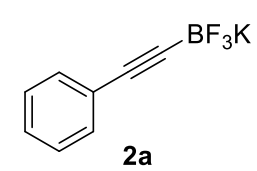


${ }^{1} \mathrm{H} \mathrm{NMR}$ (400 MHz, $\mathrm{CDCl}_{3}$ ) of compound $\mathbf{3 a}$ (purity determination):
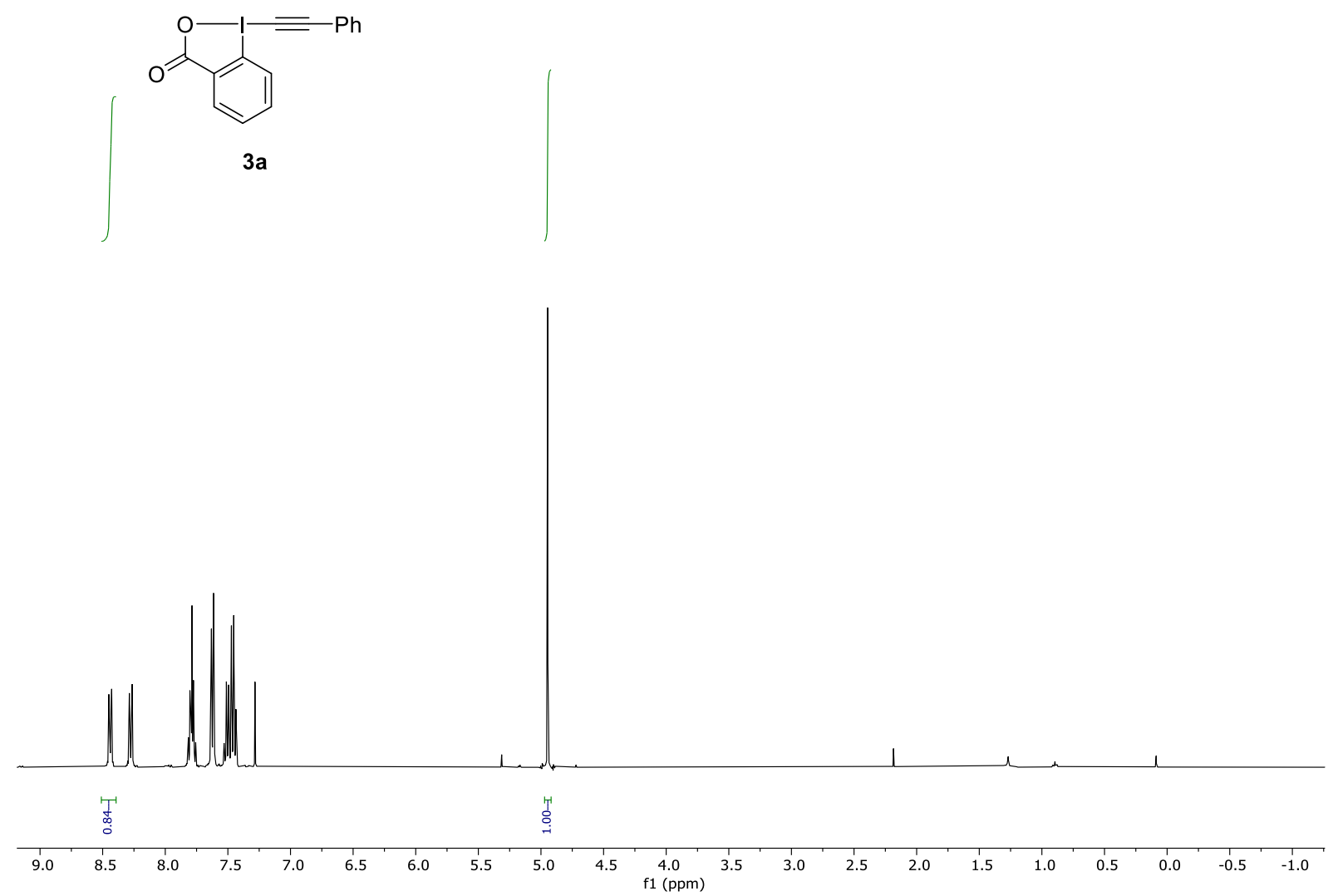

${ }^{1} \mathrm{H}$ NMR (400 MHz, $\mathrm{CDCl}_{3}$ ) of compound $\mathbf{3 a}$ :

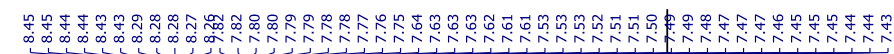

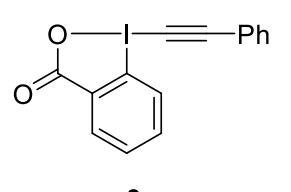

3a

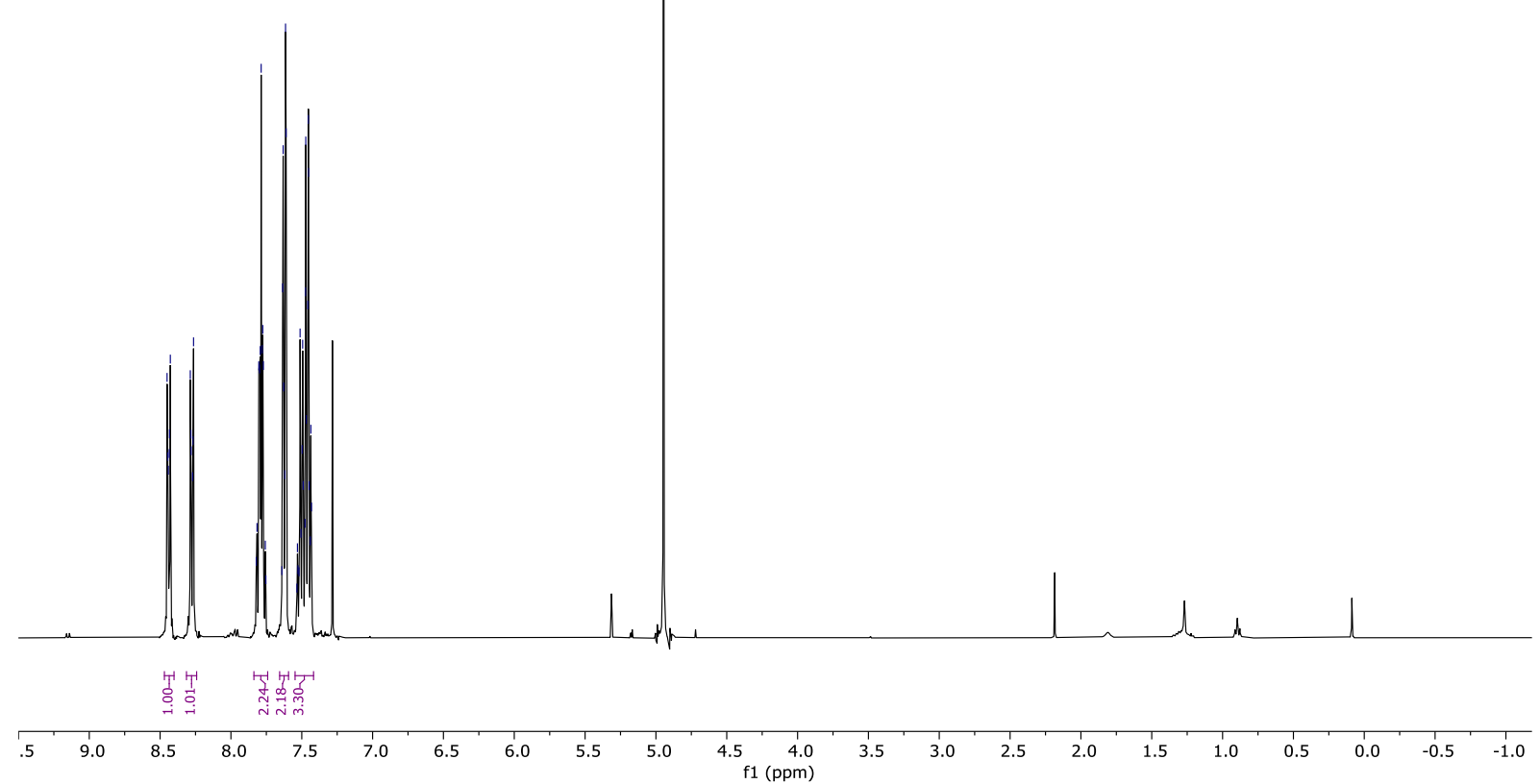


${ }^{13} \mathrm{C}$ NMR (101 MHz, $\left.\mathrm{CDCl}_{3}\right)$ of compound Ba:
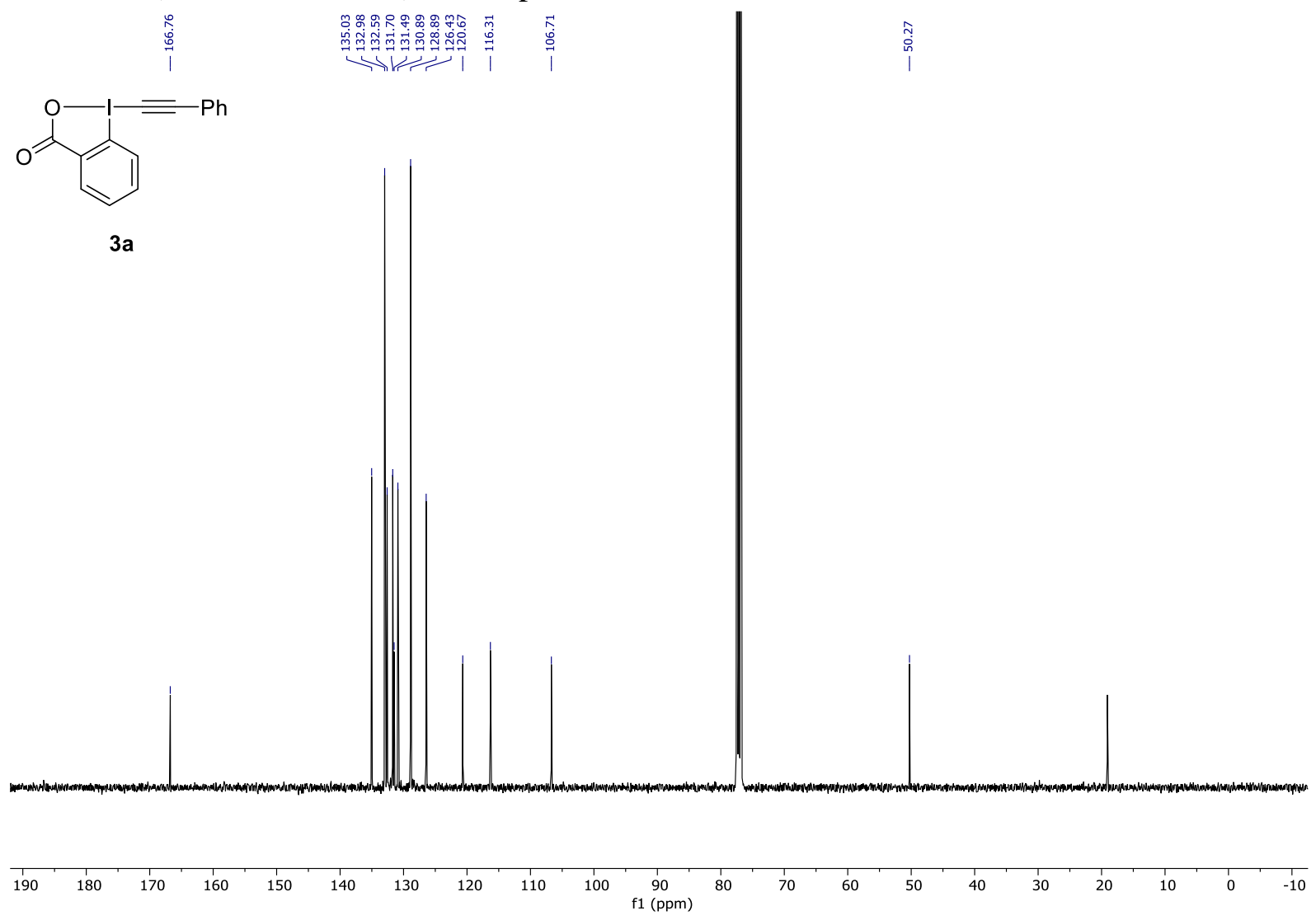

${ }^{1} \mathrm{H}$ NMR (400 MHz, $\mathrm{CDCl}_{3}$ ) of compound $\mathbf{3 b}$ (purity determination):
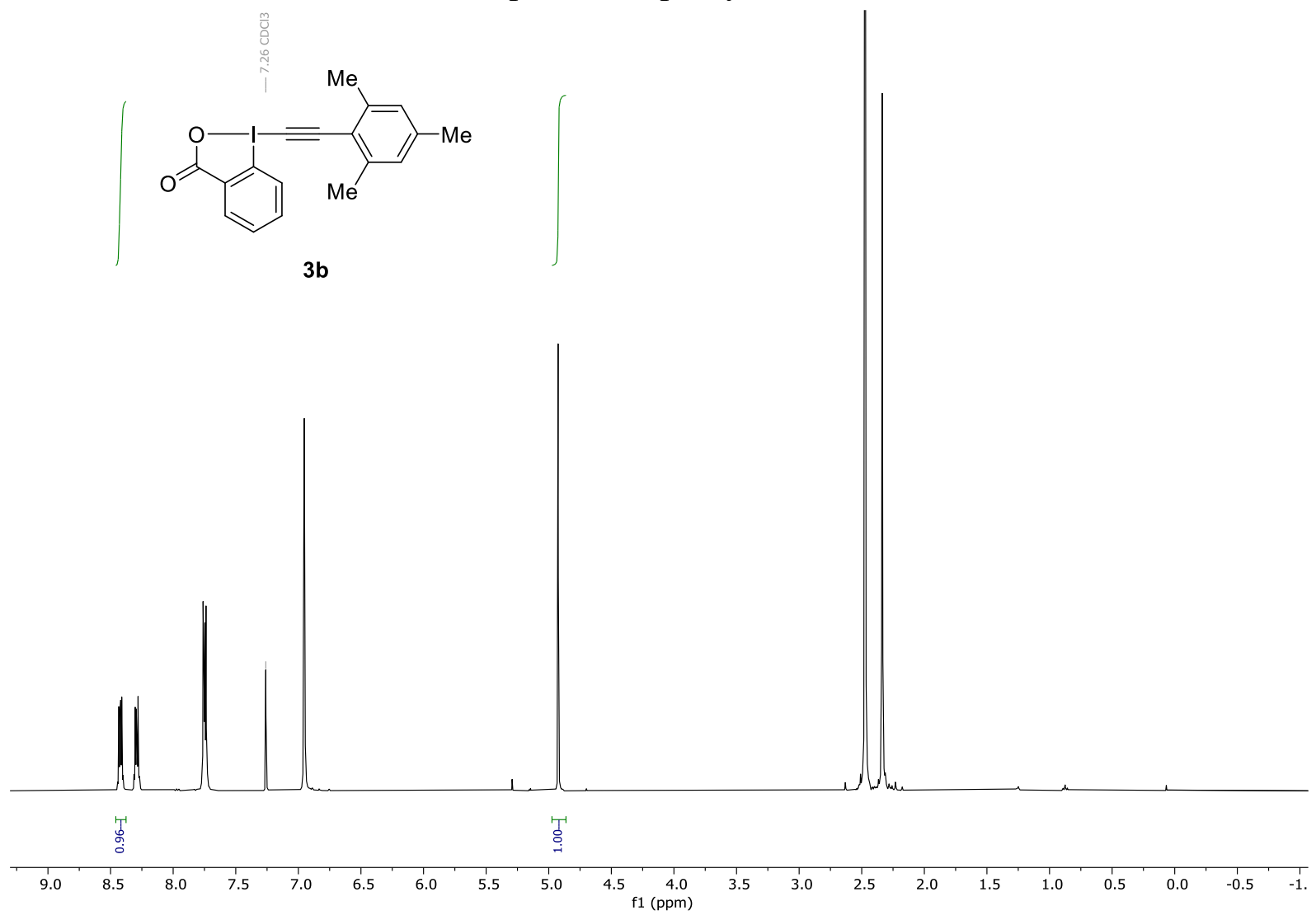

S49 
${ }^{1} \mathrm{H}$ NMR (400 MHz, $\mathrm{CDCl}_{3}$ ) of compound $\mathbf{3 b}$ :

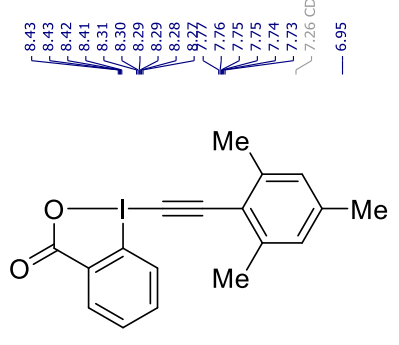

$3 \mathbf{b}$

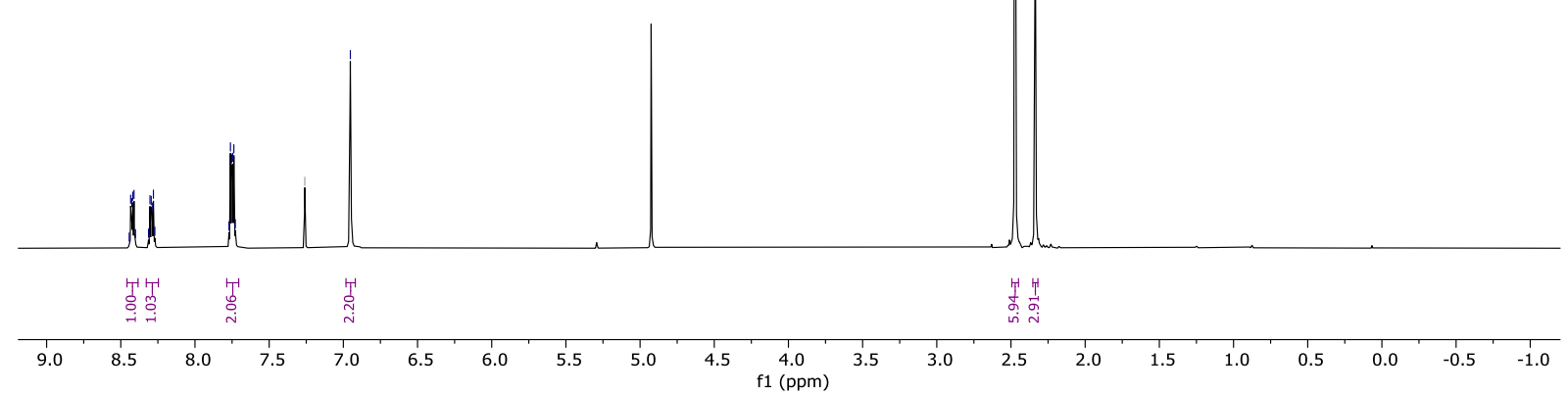

${ }^{13} \mathrm{C}$ NMR (101 MHz, $\mathrm{CDCl}_{3}$ ) of compound $\mathbf{3 b}$ :

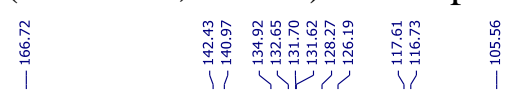

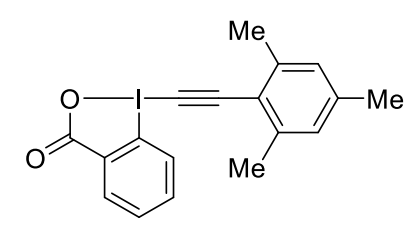

3b
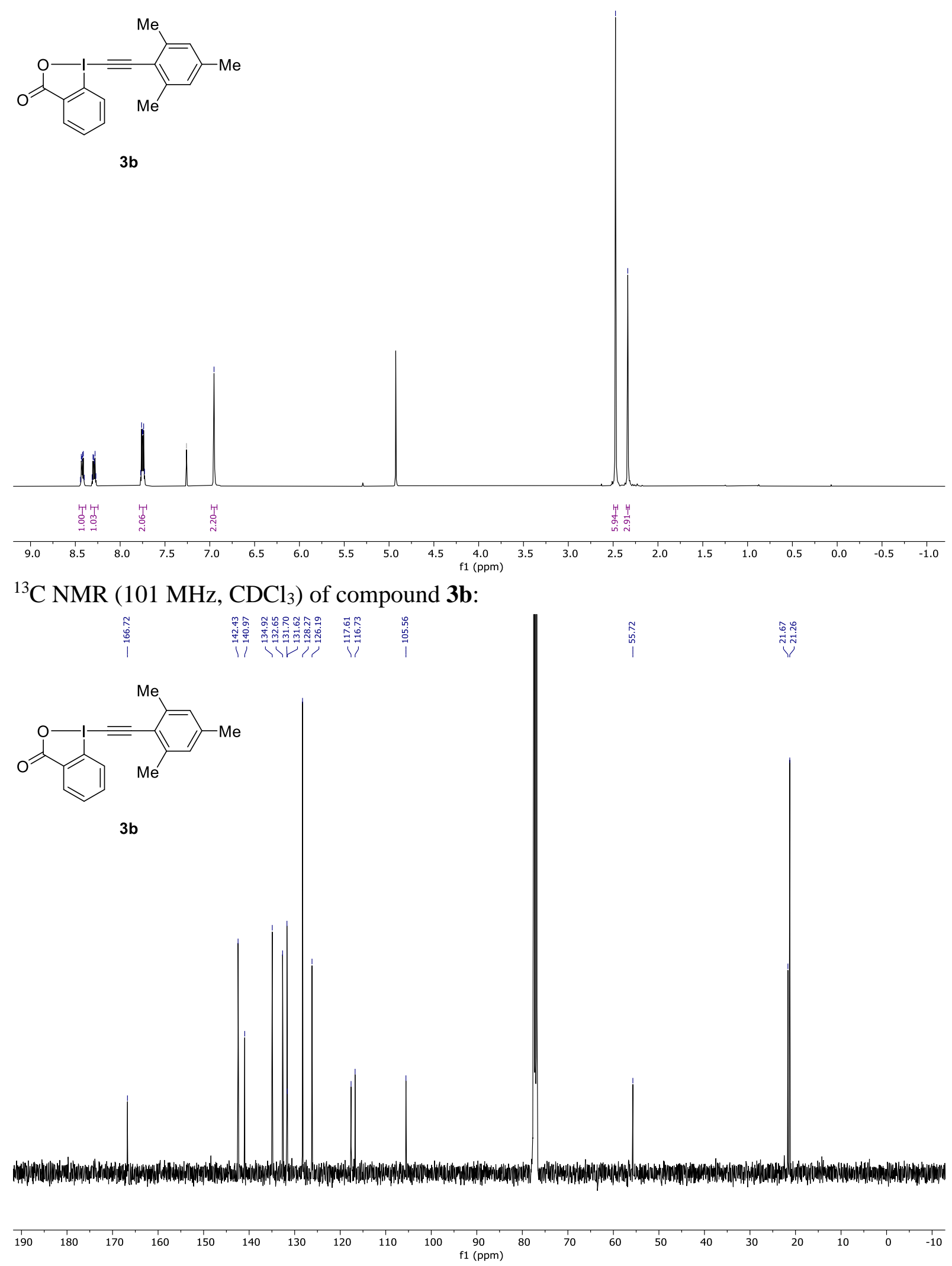
${ }^{1} \mathrm{H}$ NMR (400 MHz, $\mathrm{CDCl}_{3}$ ) of compound $\mathbf{3 c}$ (purity determination):

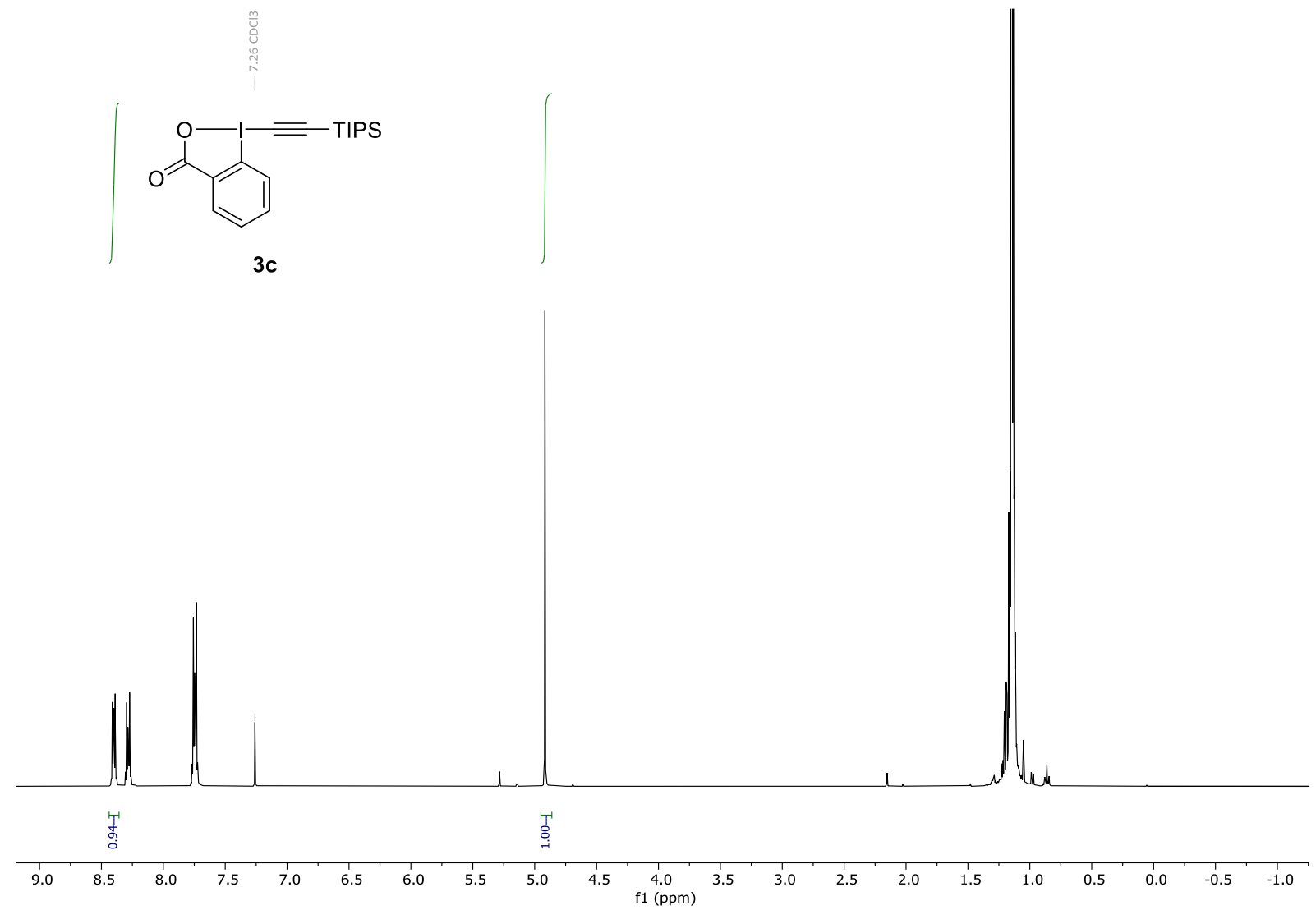

${ }^{1} \mathrm{H}$ NMR (400 MHz, $\mathrm{CDCl}_{3}$ ) of compound $\mathbf{3 c}$ :

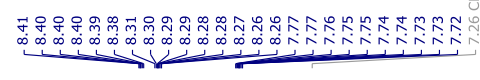

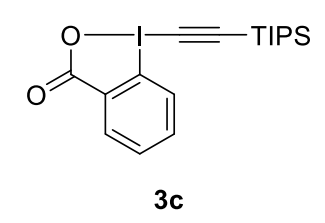

$3 c$

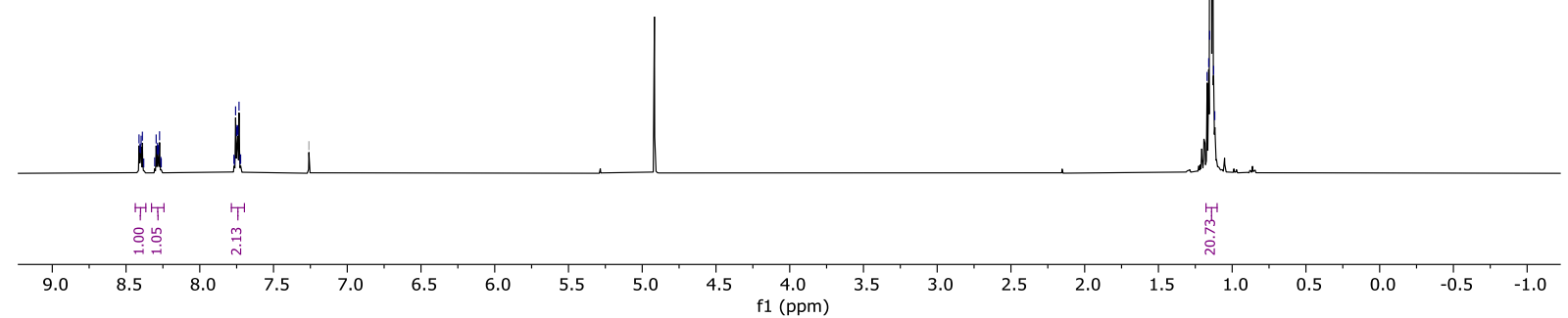


${ }^{13} \mathrm{C}$ NMR (101 MHz, $\mathrm{CDCl}_{3}$ ) of compound 3c:
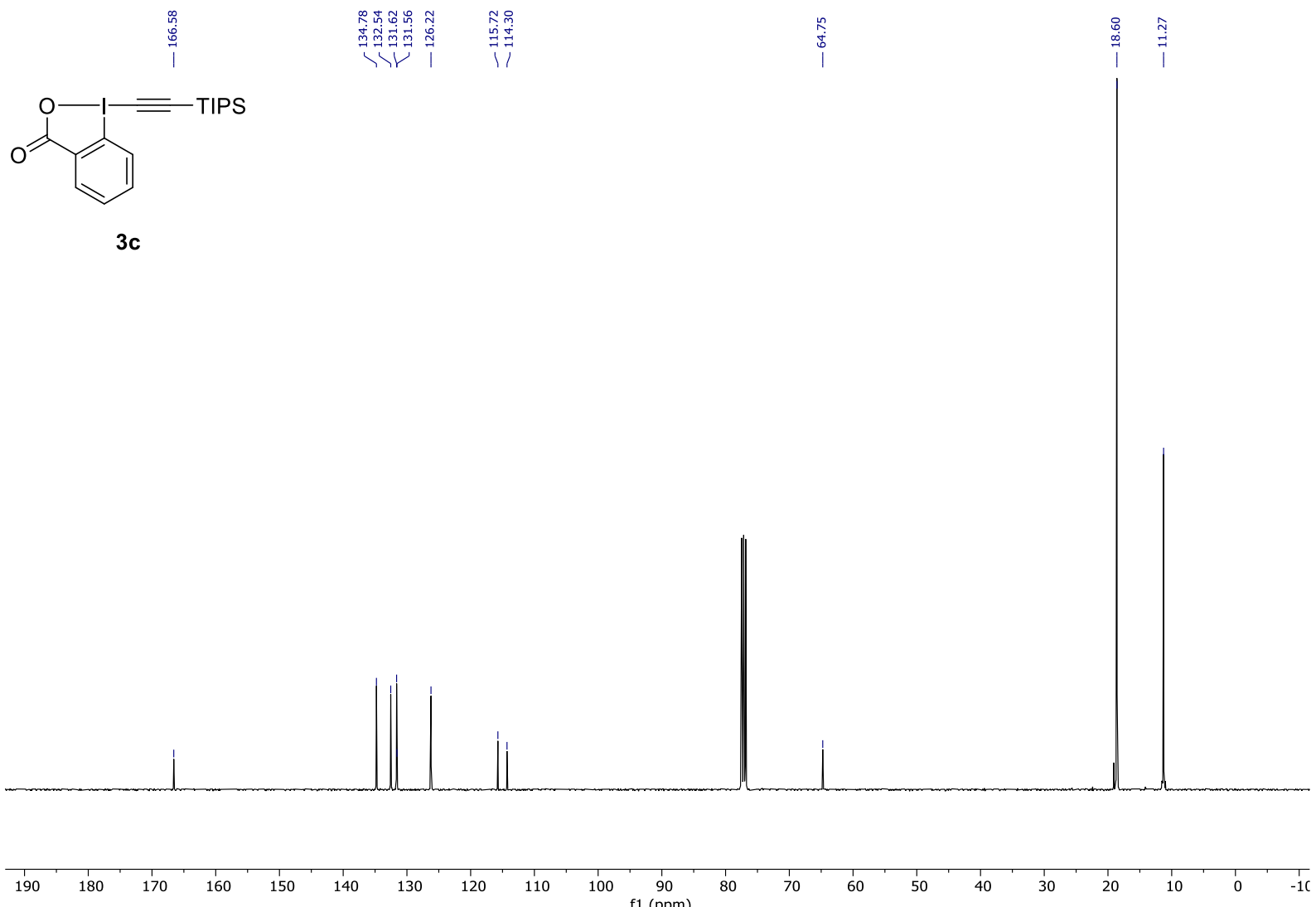

${ }^{1} \mathrm{H} \mathrm{NMR}\left(400 \mathrm{MHz}, \mathrm{CDCl}_{3}\right.$ ) of compound $\mathbf{3 d}$ (purity determination):
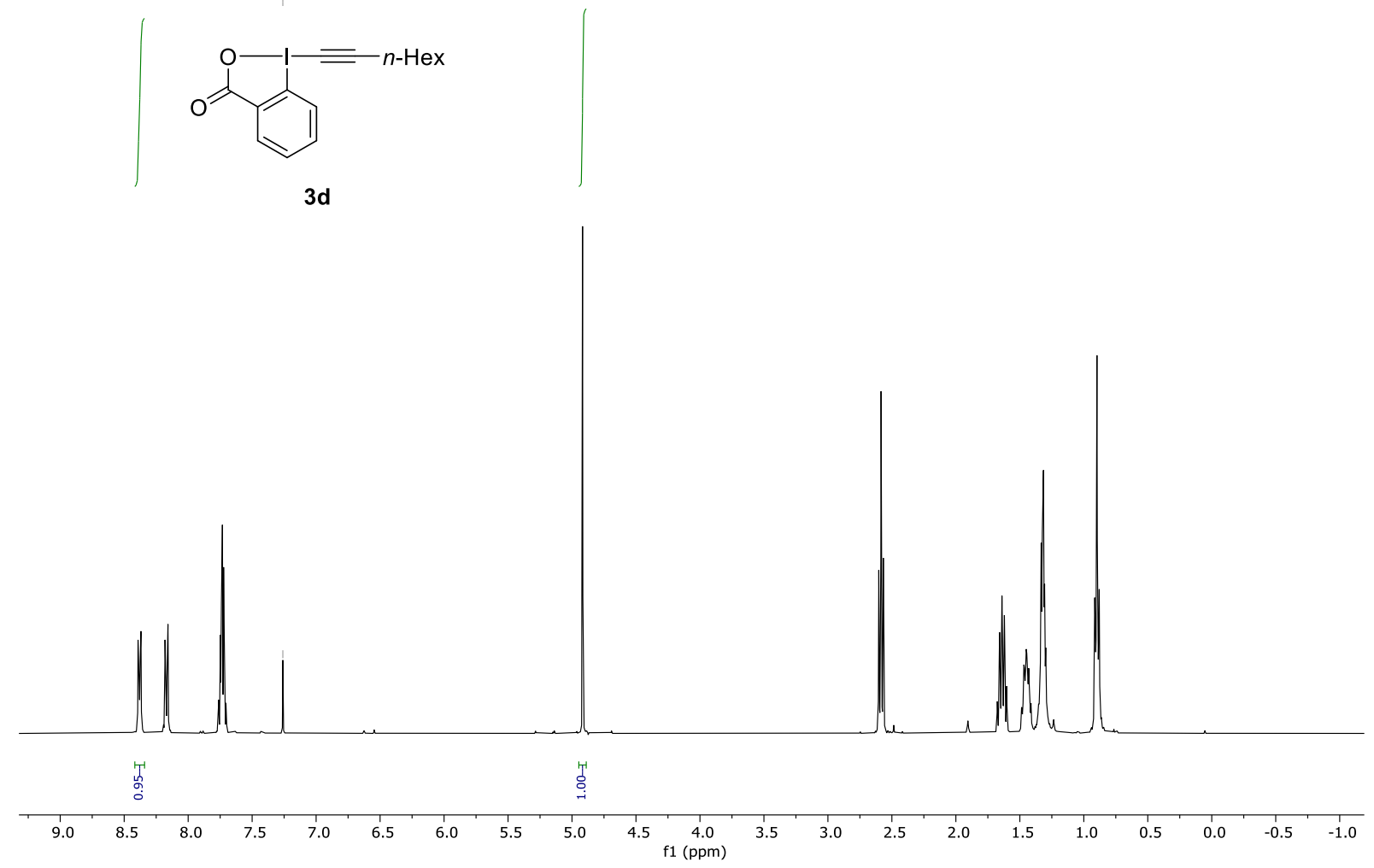
${ }^{1} \mathrm{H}$ NMR (400 MHz, $\mathrm{CDCl}_{3}$ ) of compound $\mathbf{3 d}$ :

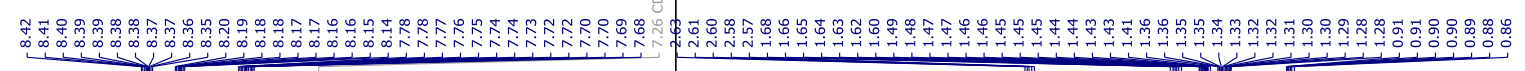<smiles>O=C1OI(C#CC=CC2CCCCC2)c2ccccc21</smiles>

3d

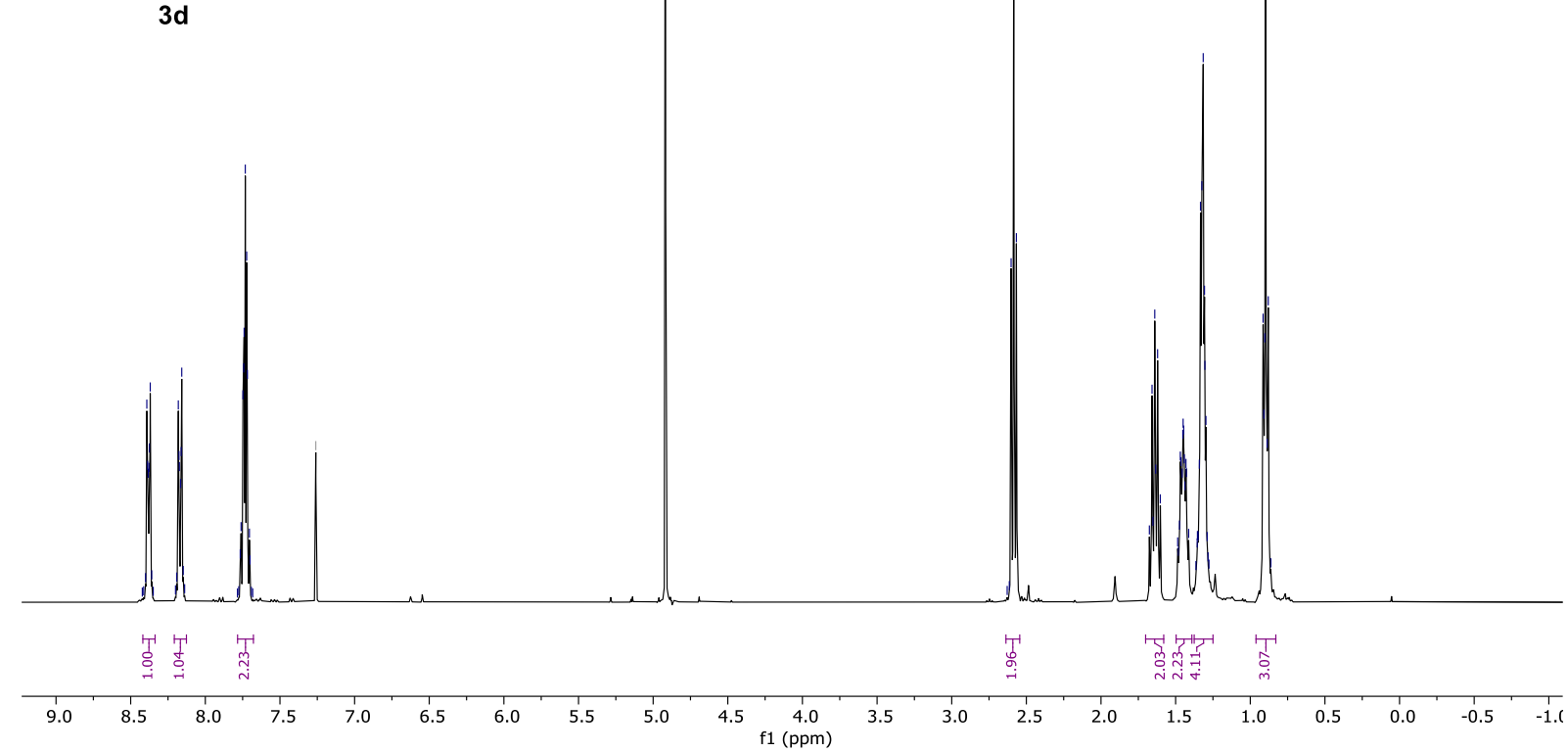

${ }^{13} \mathrm{C}$ NMR (101 MHz, $\mathrm{CDCl}_{3}$ ) of compound $\mathbf{3 d}$ :
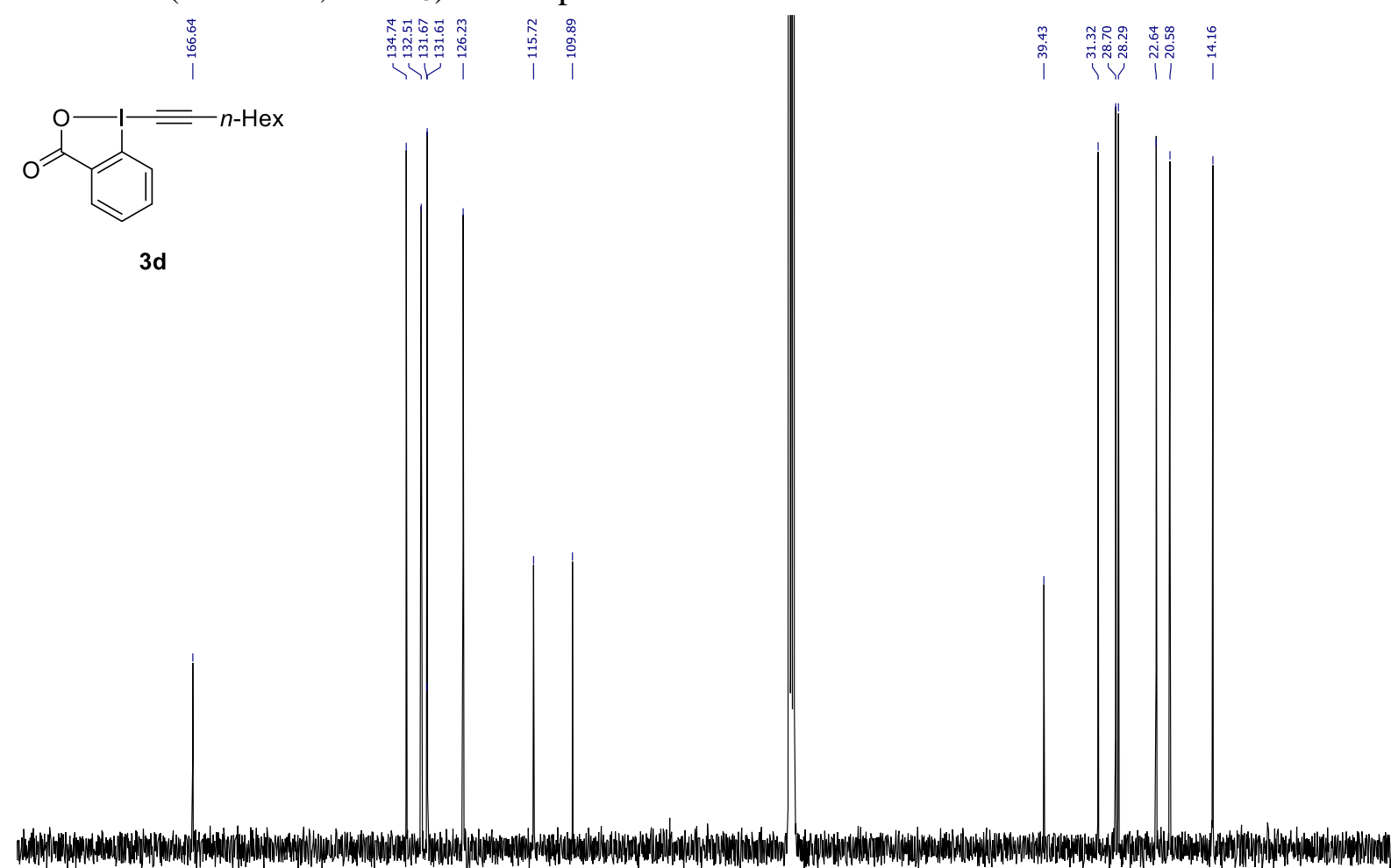

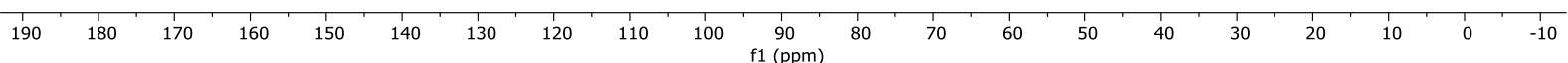


${ }^{1} \mathrm{H} \mathrm{NMR}$ (400 MHz, $\mathrm{CDCl}_{3}$ ) of compound $\mathbf{3 e}$ (purity determination):

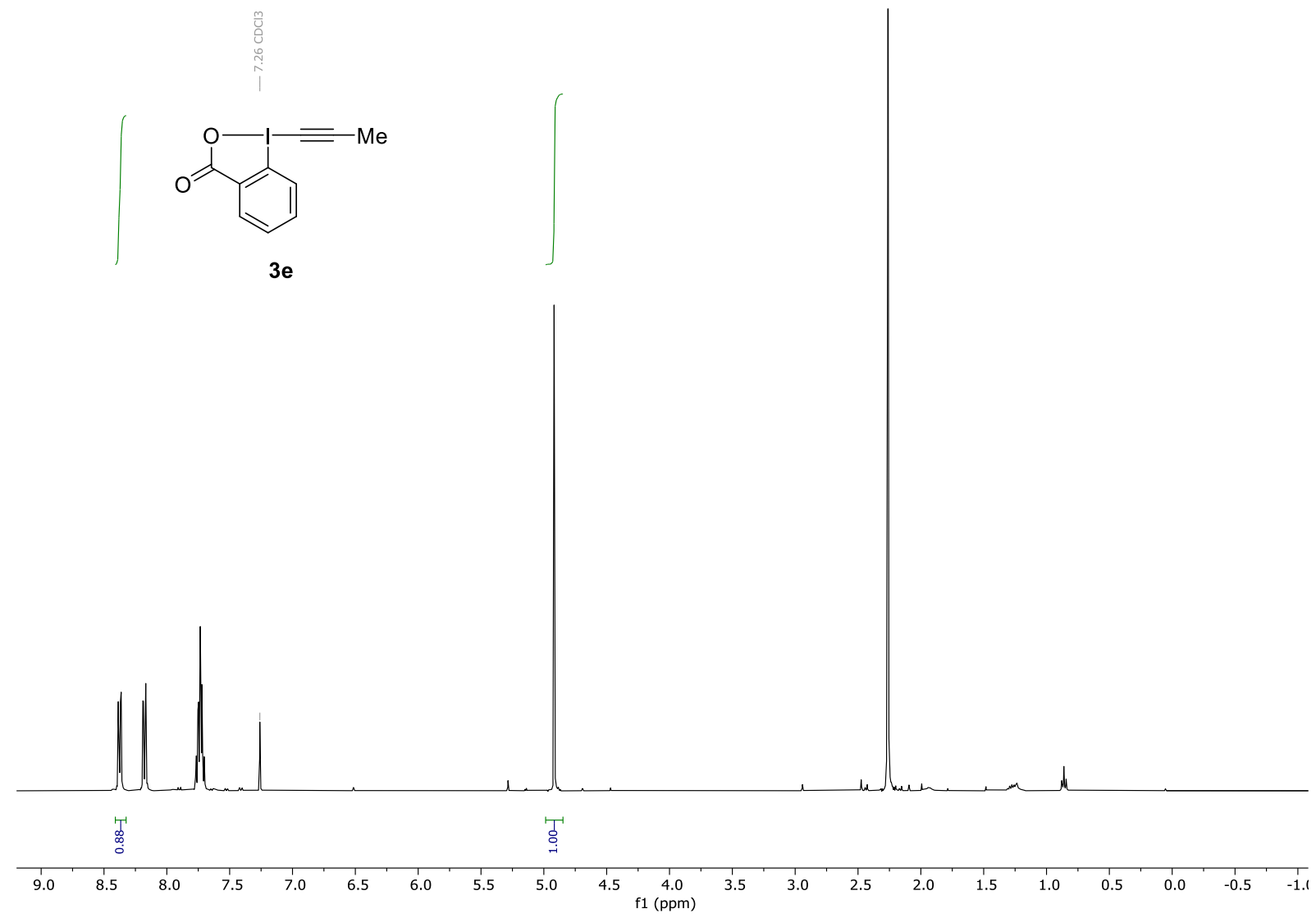

${ }^{1} \mathrm{H}$ NMR (400 MHz, $\mathrm{CDCl}_{3}$ ) of compound $\mathbf{3 e}$ :
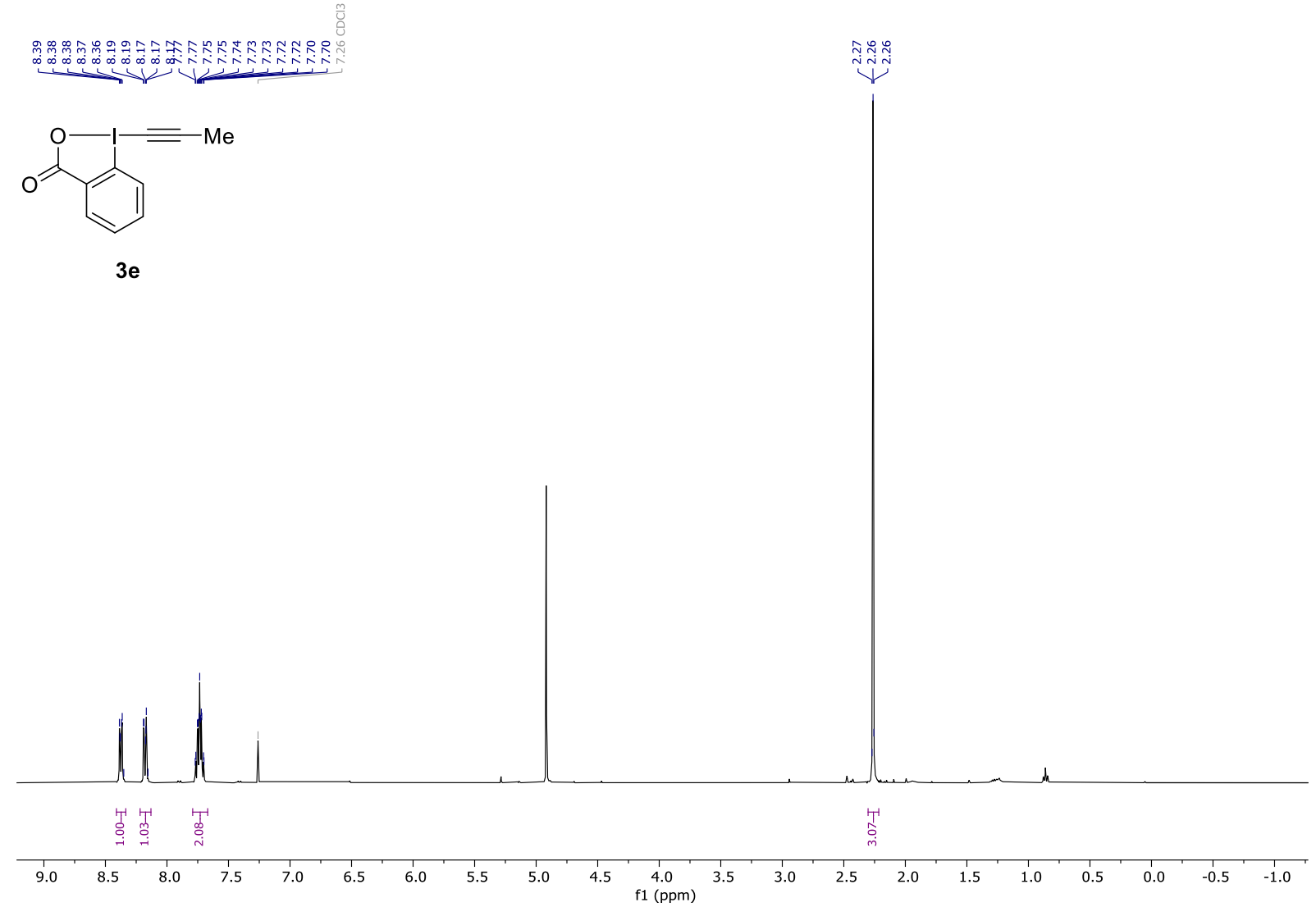
${ }^{13} \mathrm{C}$ NMR (101 MHz, $\left.\mathrm{CDCl}_{3}\right)$ of compound 3e:

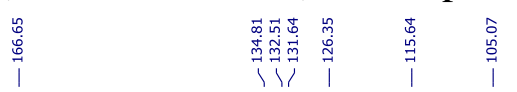<smiles>CC#CI1OC(=O)c2ccccc21</smiles>

$3 e$

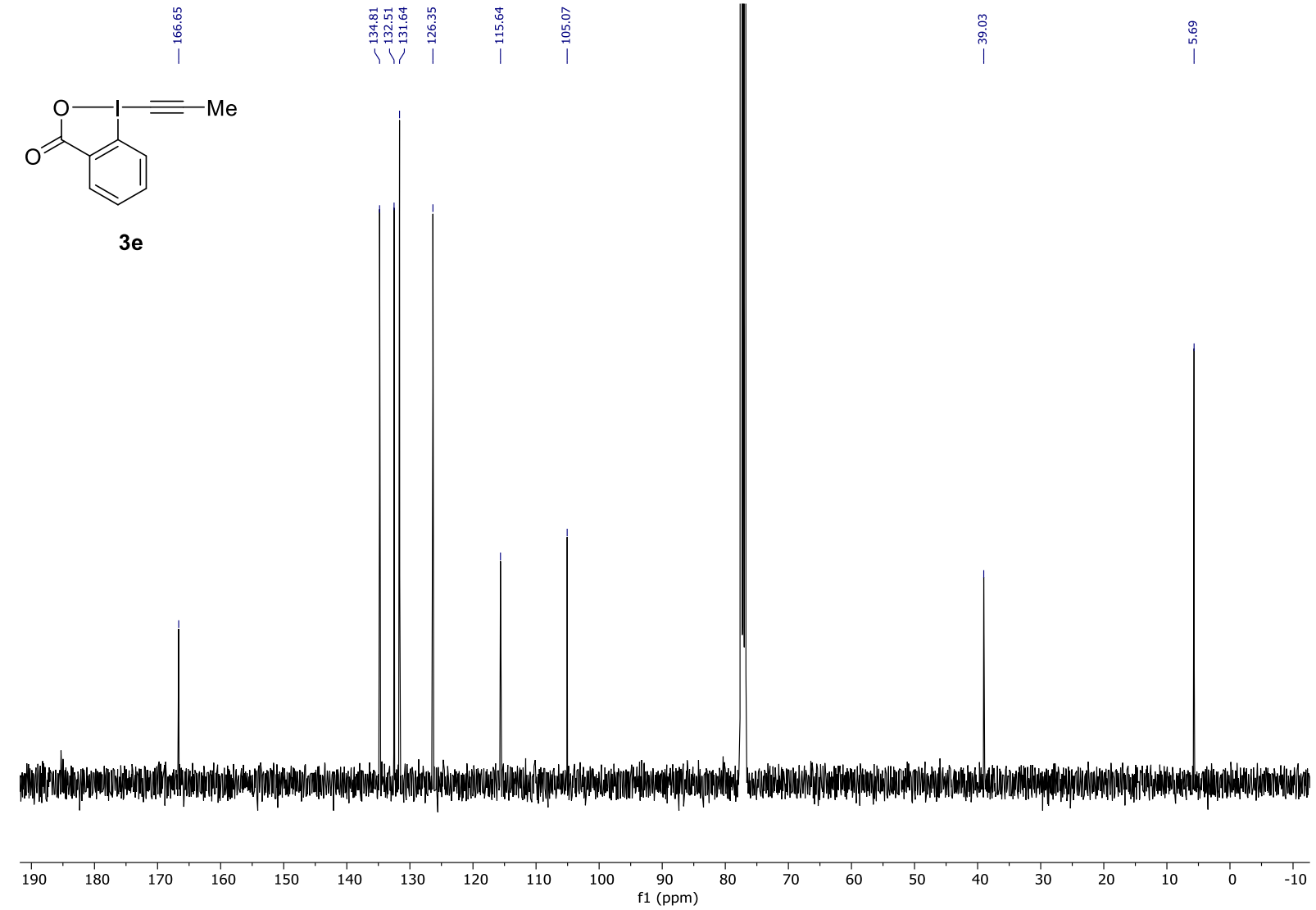

${ }^{1} \mathrm{H}$ NMR (400 MHz, $\mathrm{CDCl}_{3}$ ) of compound $\mathbf{3 f}$ (purity determination):

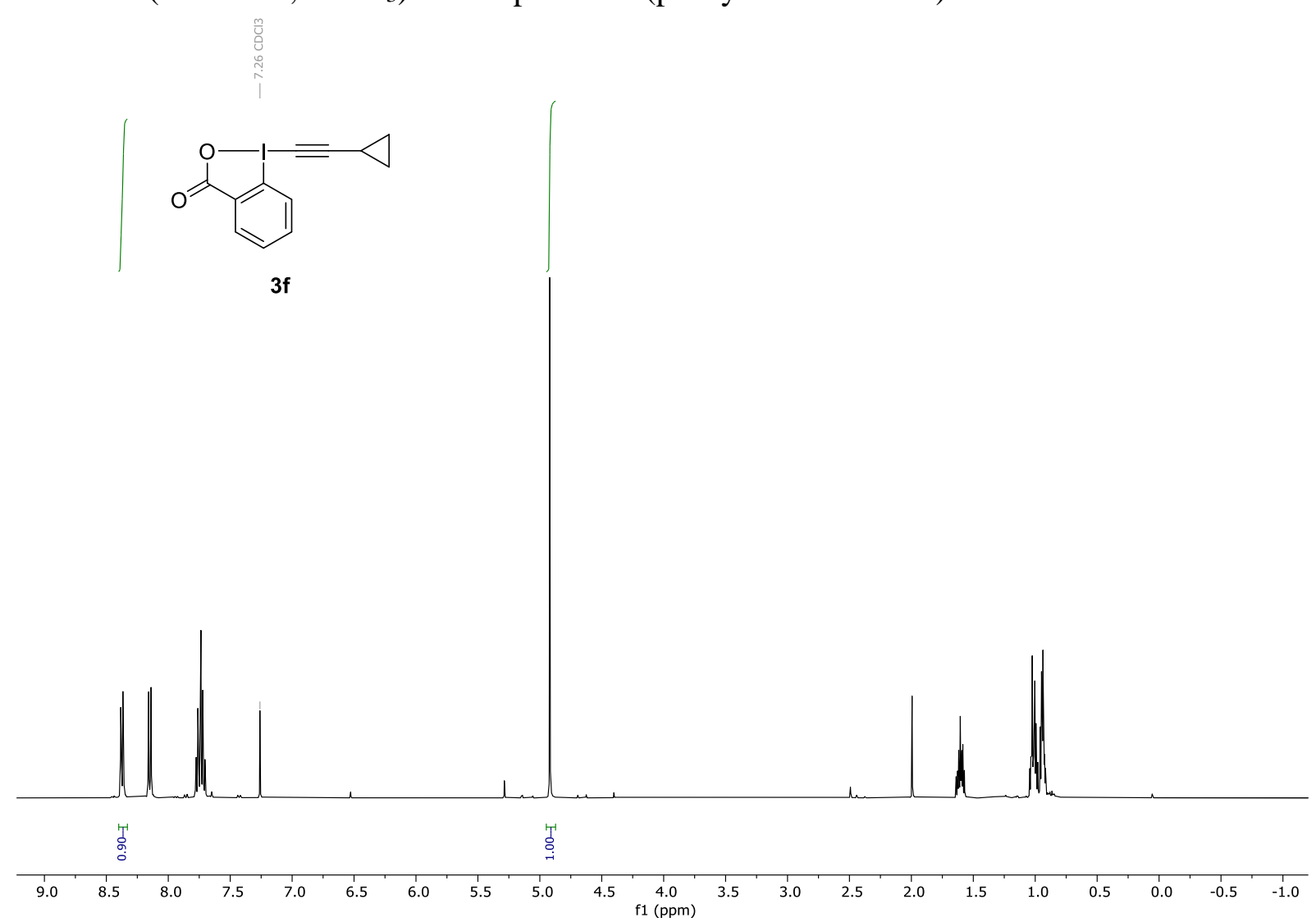


${ }^{1} \mathrm{H}$ NMR (400 MHz, $\mathrm{CDCl}_{3}$ ) of compound $\mathbf{3 f}$ :

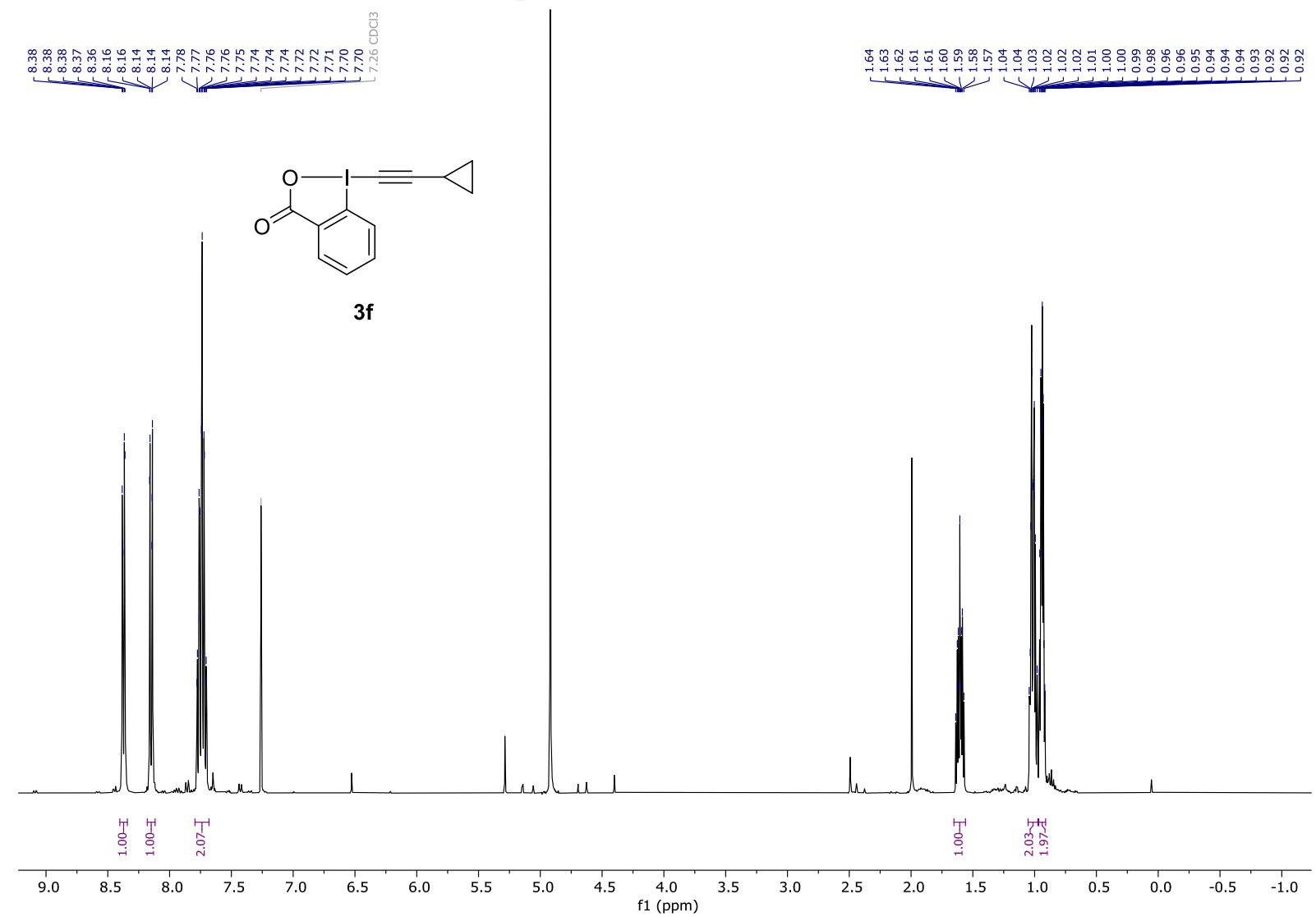

${ }^{13} \mathrm{C}$ NMR (101 MHz, $\mathrm{CDCl}_{3}$ ) of compound $\mathbf{3 f}$ :

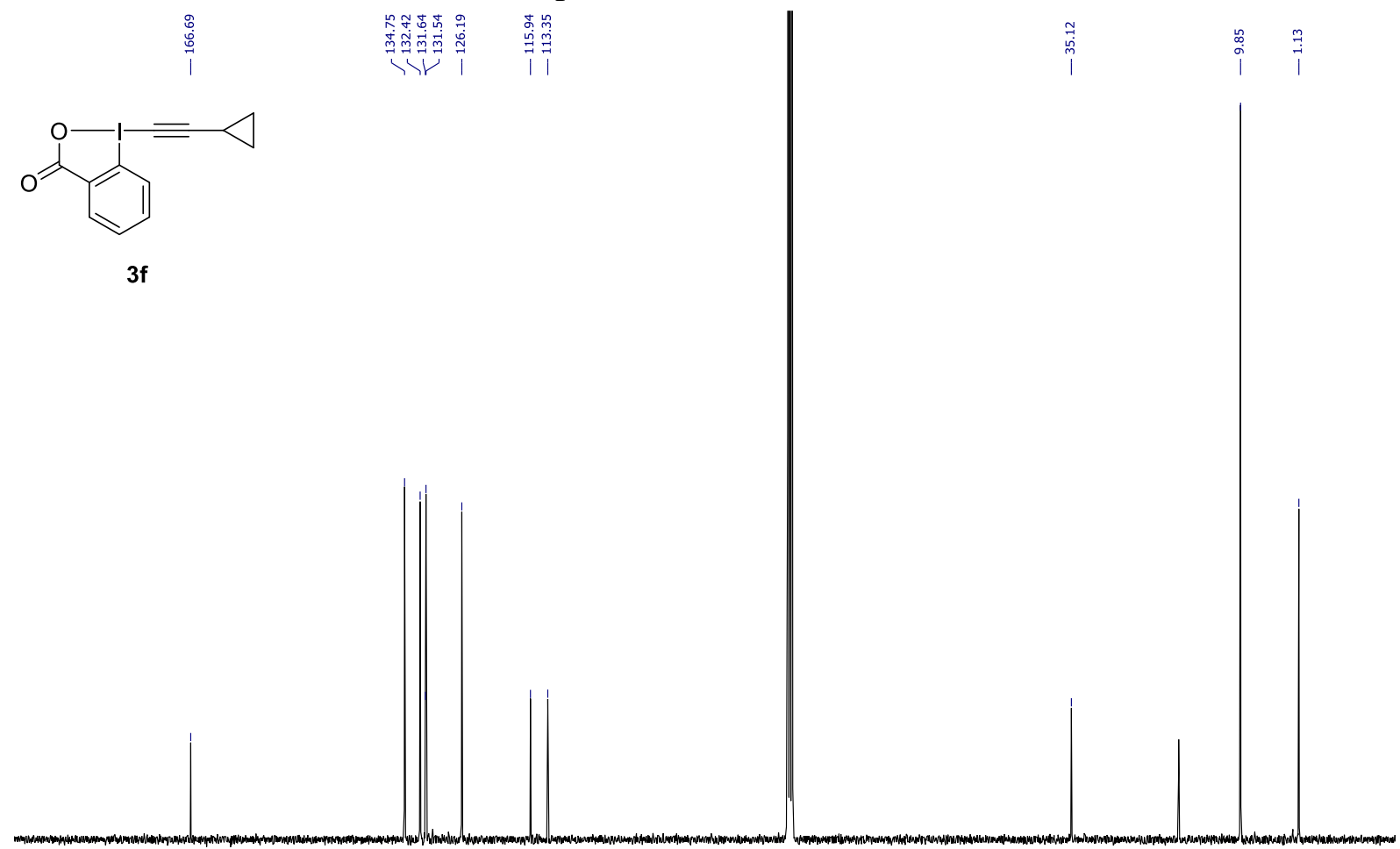

190

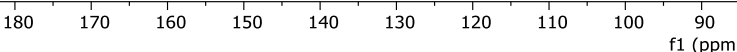

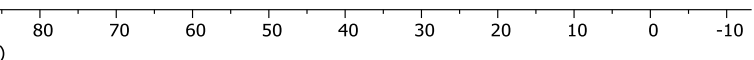


${ }^{1} \mathrm{H} \mathrm{NMR}$ (400 MHz, $\mathrm{CDCl}_{3}$ ) of compound $\mathbf{3 g}$ (purity determination):

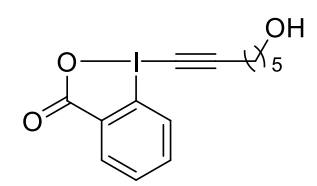

$3 g$

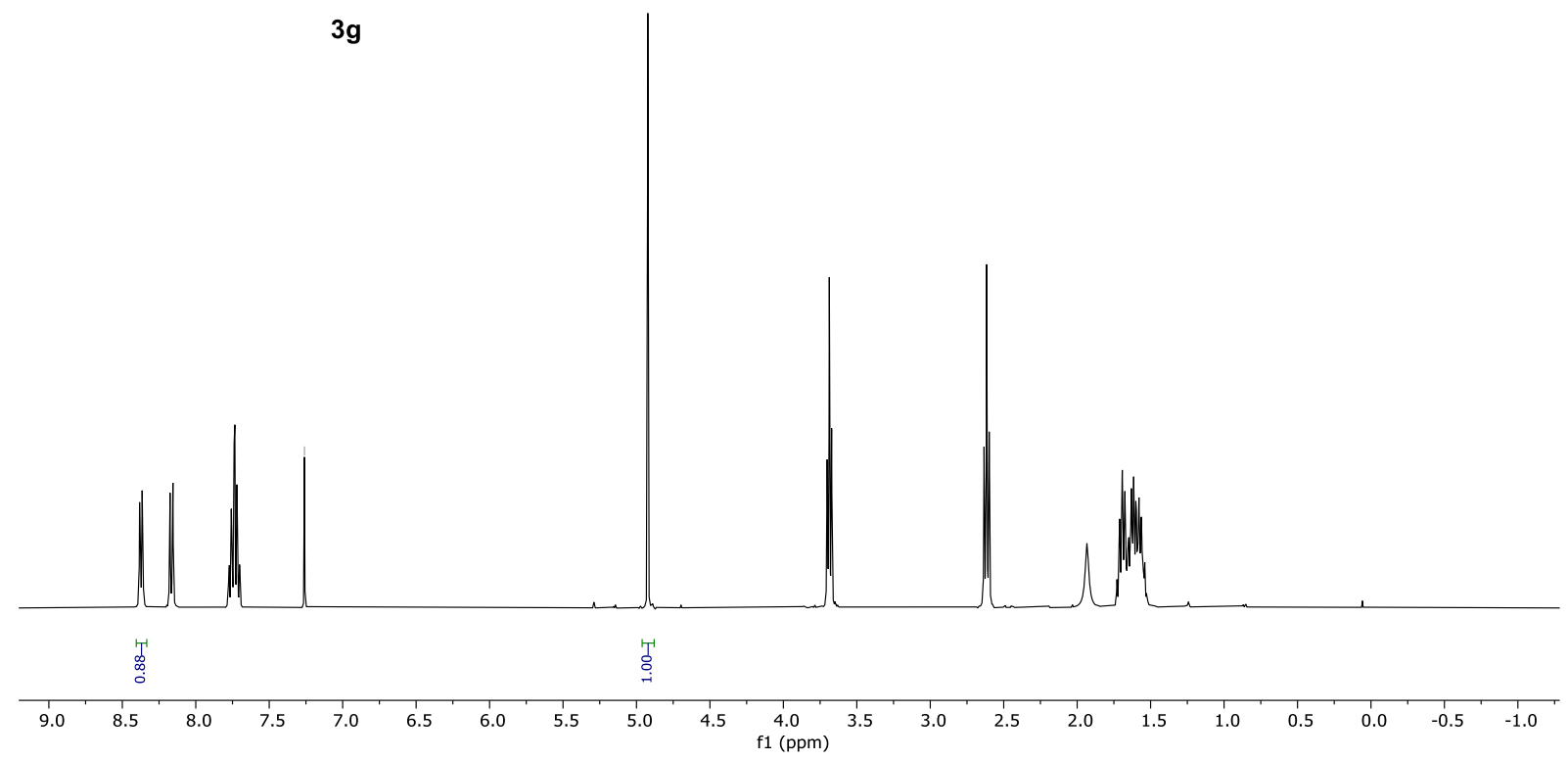

${ }^{1} \mathrm{H}$ NMR (400 MHz, $\mathrm{CDCl}_{3}$ ) of compound $\mathbf{3 g}$ :

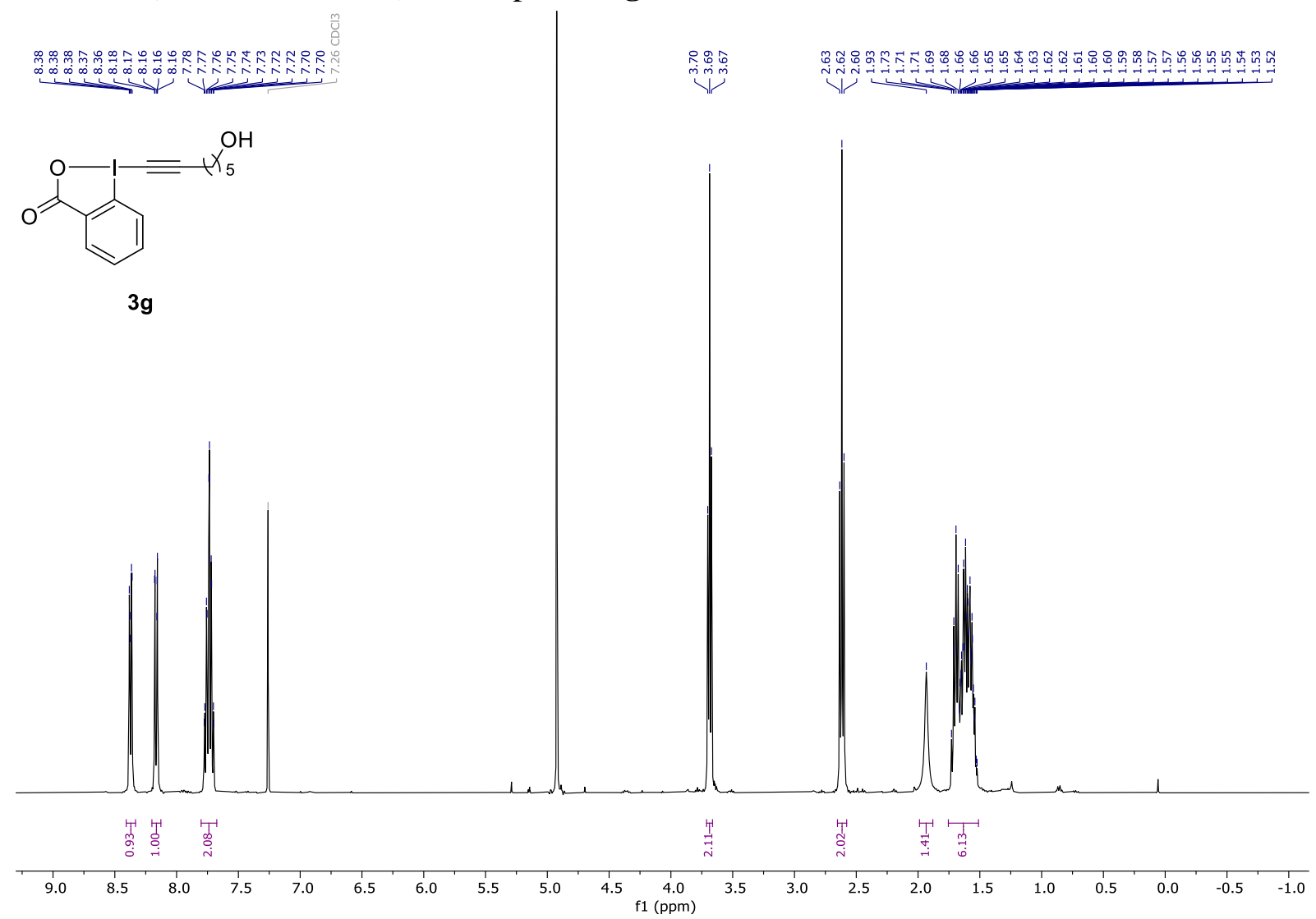


${ }^{13} \mathrm{C}$ NMR (101 MHz, $\left.\mathrm{CDCl}_{3}\right)$ of compound $\mathbf{3 g}$ :

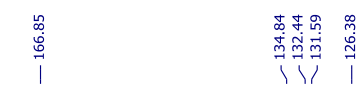

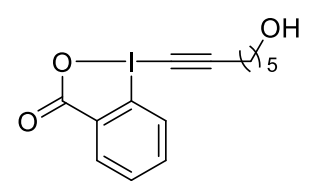

$3 \mathbf{g}$
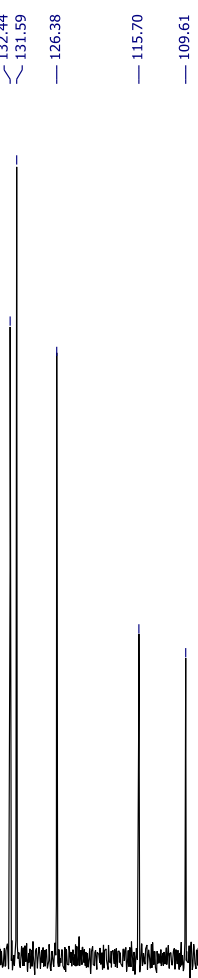

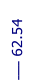

品

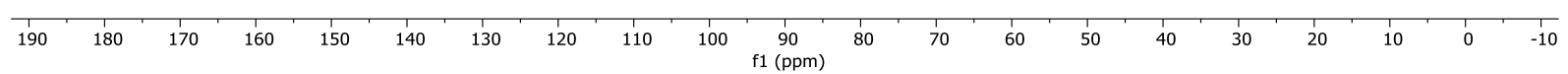

${ }^{1} \mathrm{H}$ NMR (400 MHz, $\mathrm{CDCl}_{3}$ ) of compound $\mathbf{3 h}$ (purity determination):

兽

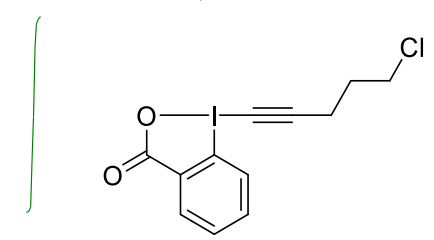

$3 h$

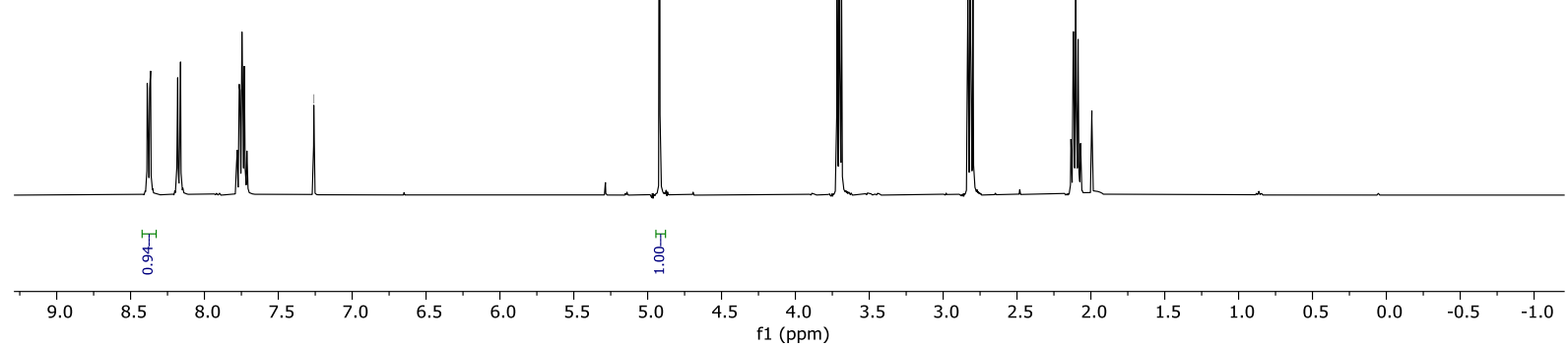

S58 
${ }^{1} \mathrm{H}$ NMR (400 MHz, $\mathrm{CDCl}_{3}$ ) of compound $\mathbf{3 h}$ :

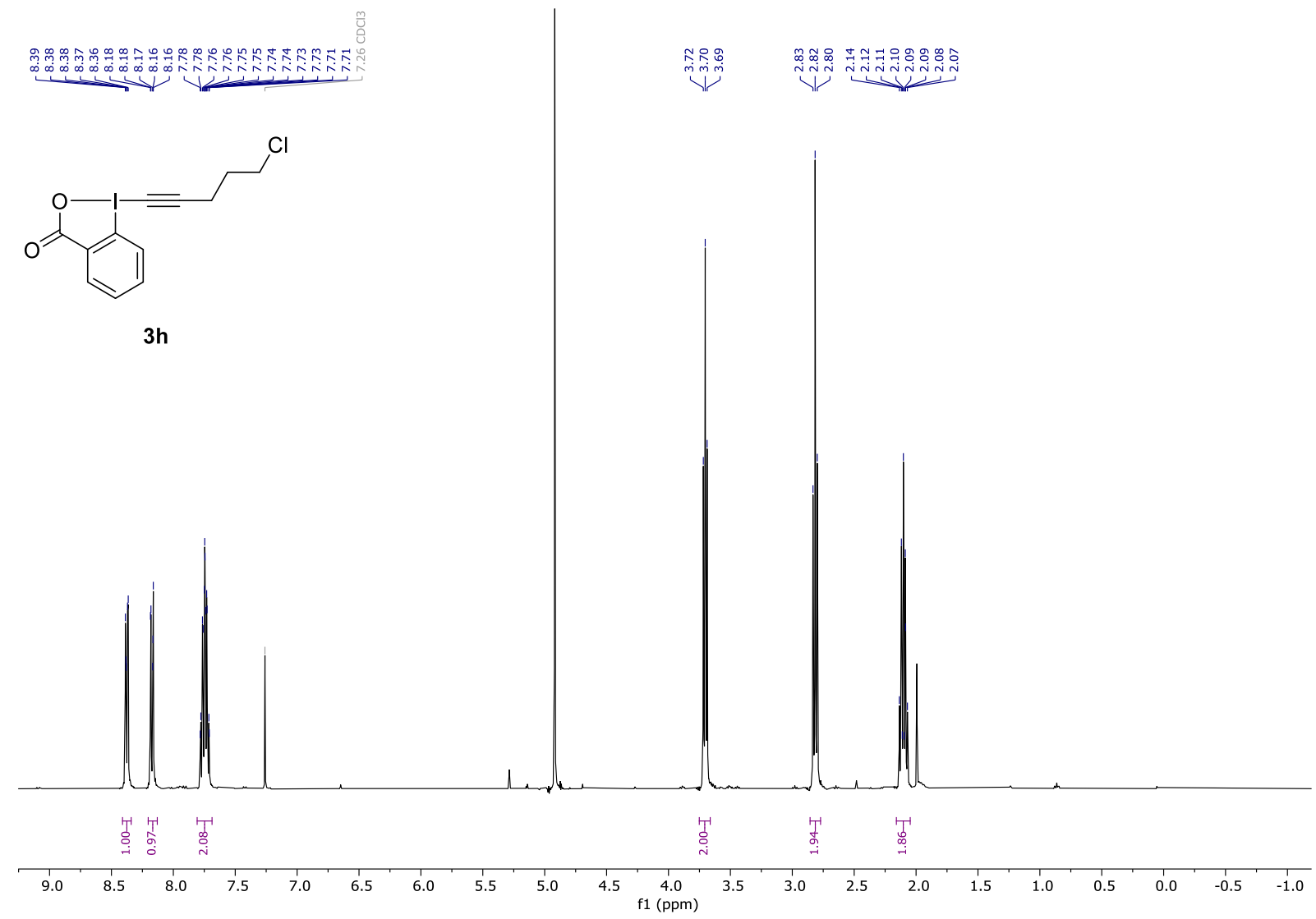

${ }^{13} \mathrm{C}$ NMR (101 MHz, $\left.\mathrm{CDCl}_{3}\right)$ of compound $\mathbf{3 h}$ :
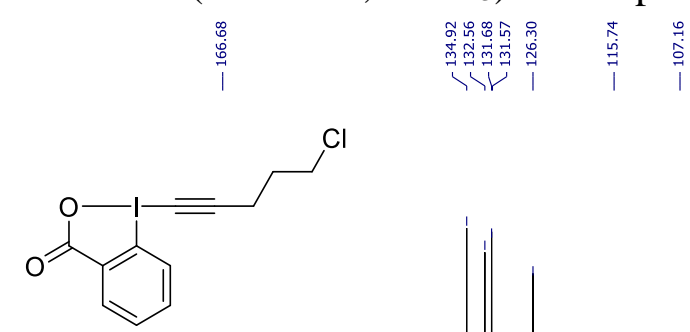

3h
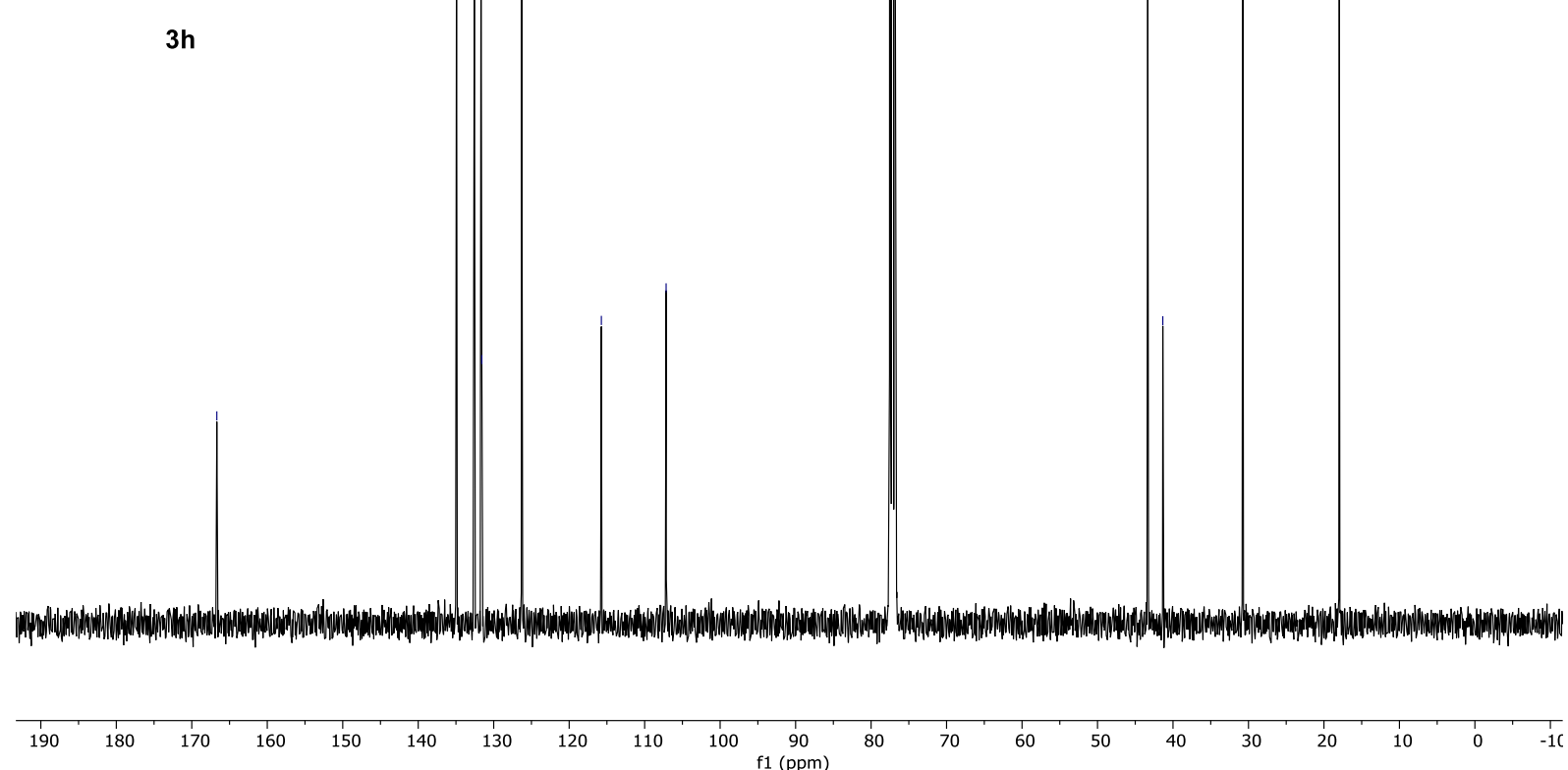
${ }^{1} \mathrm{H} \mathrm{NMR} \mathrm{(400} \mathrm{MHz,} \mathrm{CDCl}_{3}$ ) of compound $\mathbf{3 i}$ (purity determination):

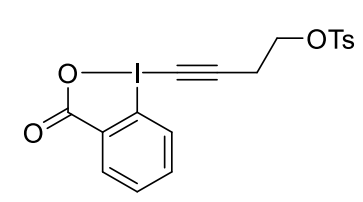

3i

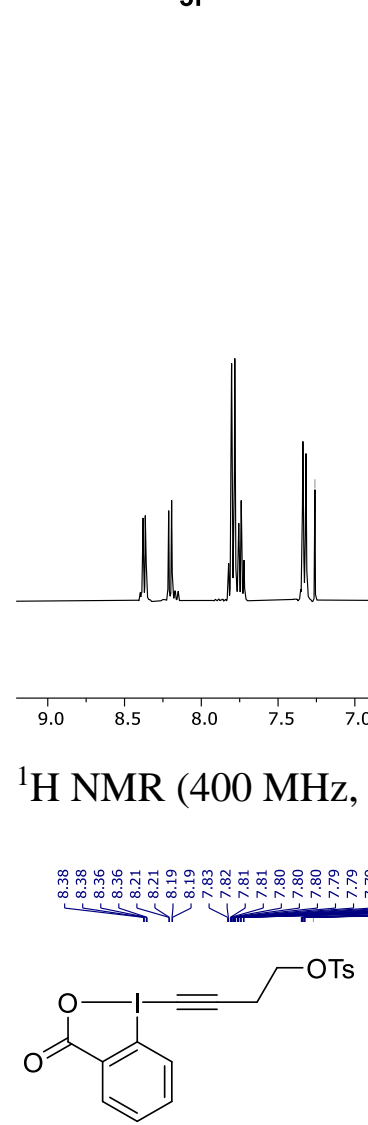

$3 \mathbf{i}$
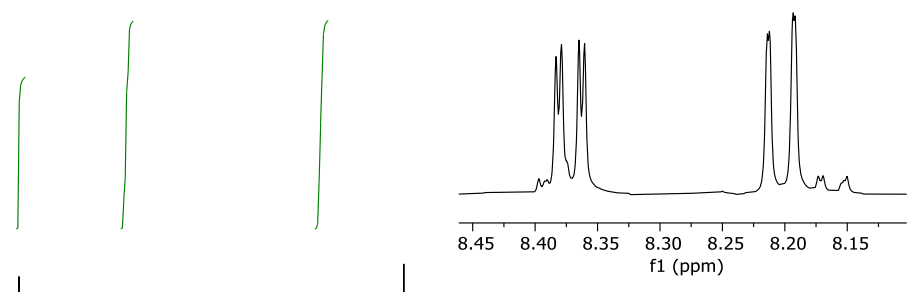

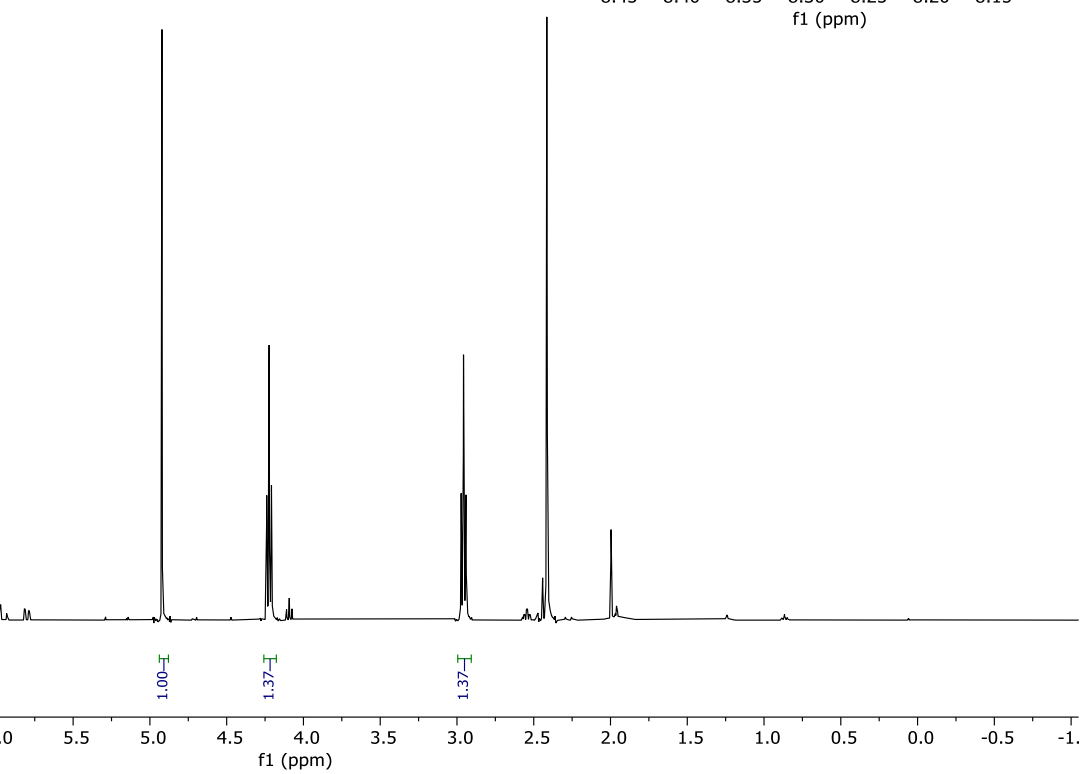

${ }^{1} \mathrm{H}$ NMR (400 MHz, $\mathrm{CDCl}_{3}$ ) of compound $\mathbf{3 i}$ :

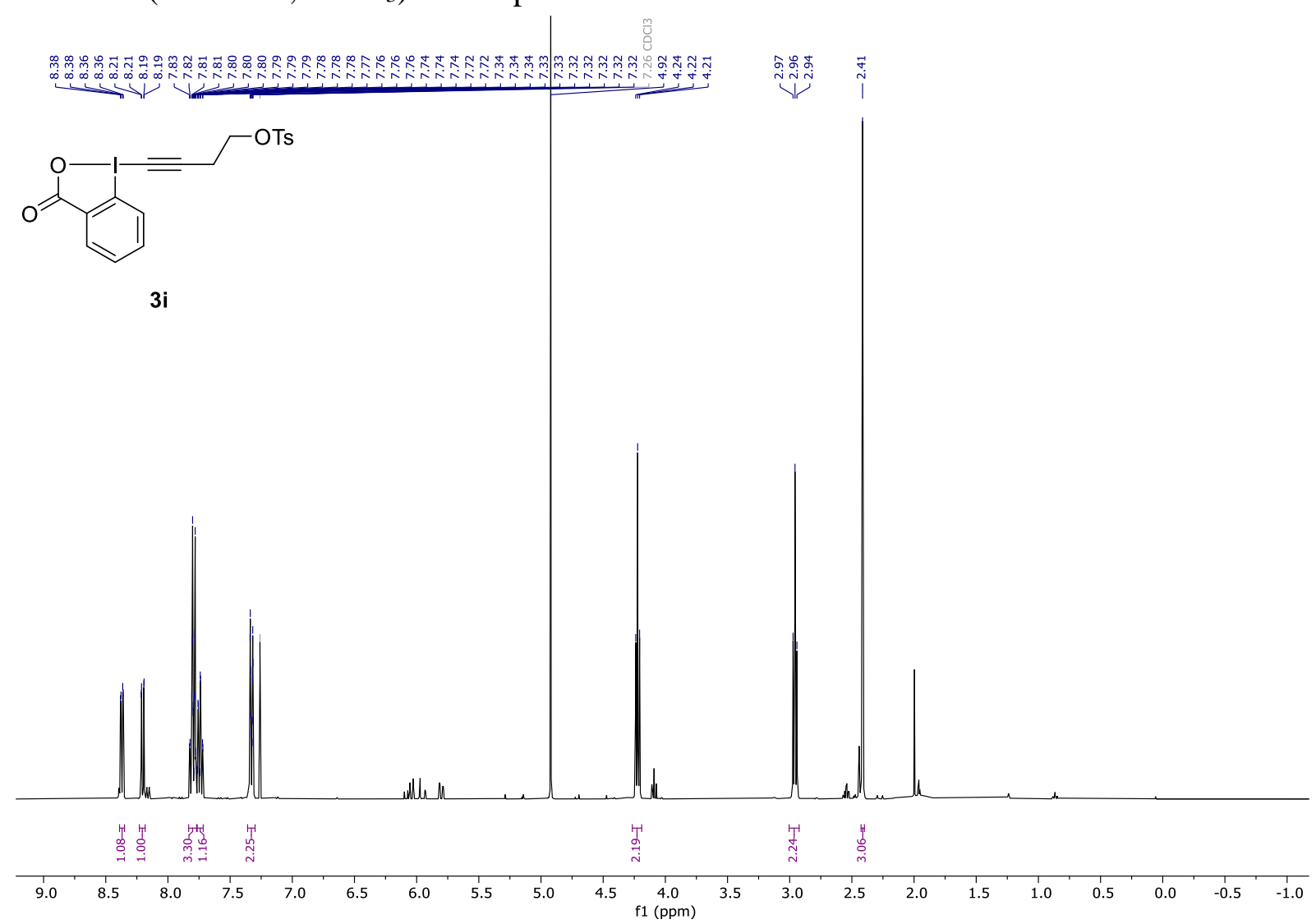


${ }^{13} \mathrm{C} \mathrm{NMR}\left(101 \mathrm{MHz}, \mathrm{CDCl}_{3}\right)$ of compound $\mathbf{3 i}$ :
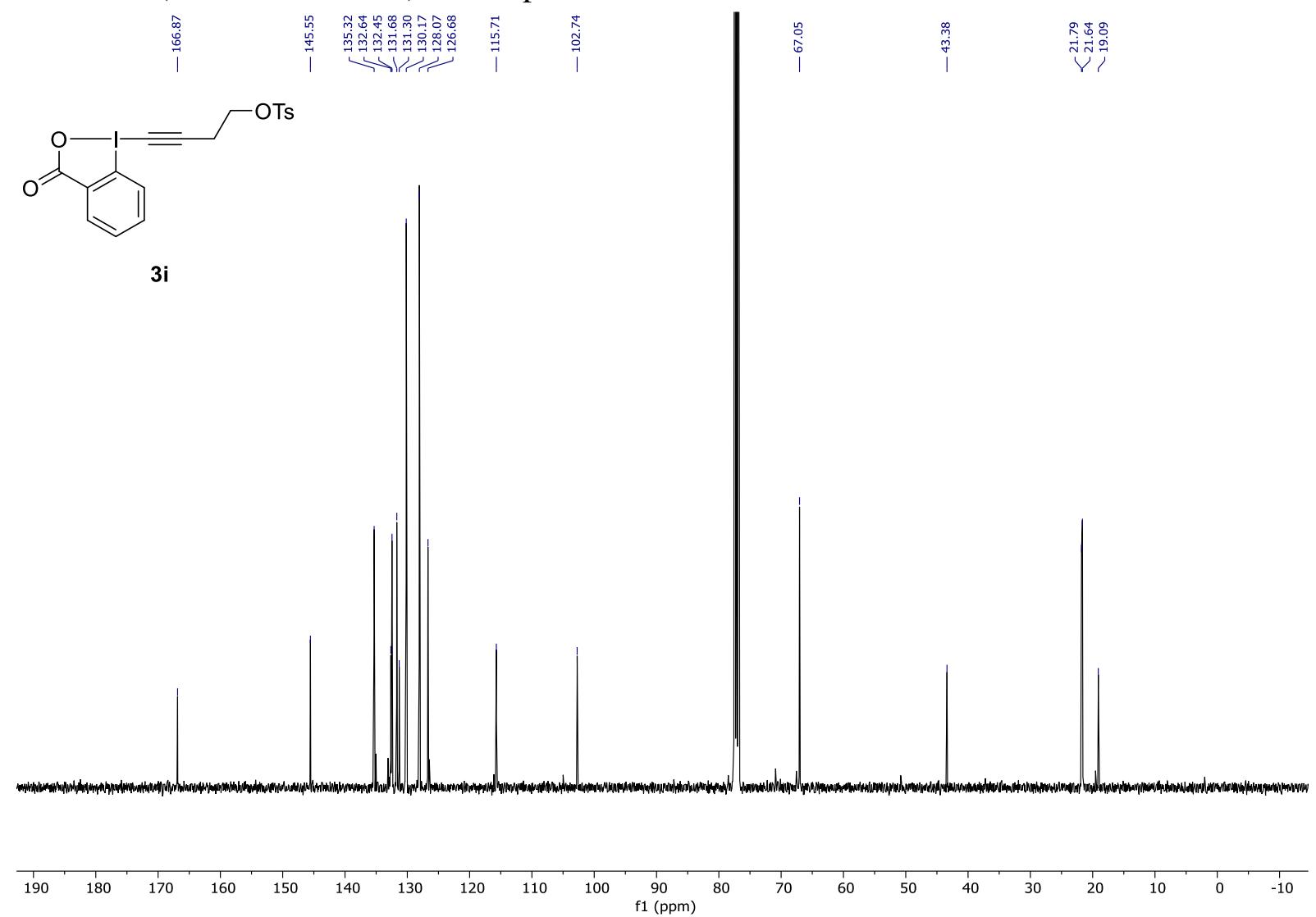

HRSM (ESI/QTOF, positive mode) of compound 3i:

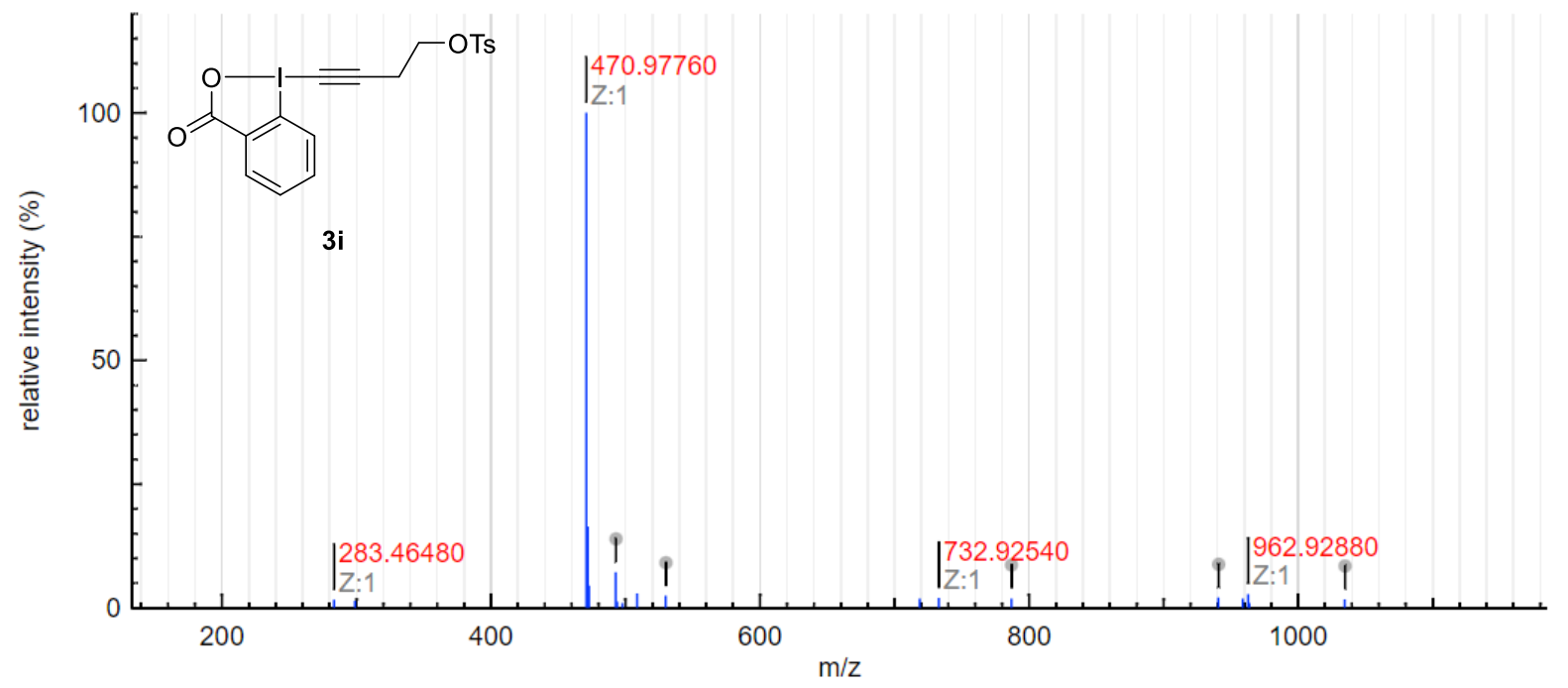


${ }^{1} \mathrm{H}$ NMR (400 MHz, $\mathrm{CDCl}_{3}$ ) of compound $\mathbf{4 a}$ :

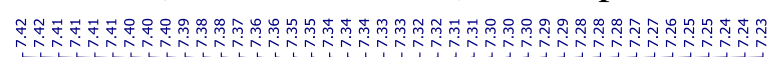

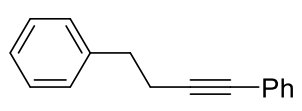

$4 a$

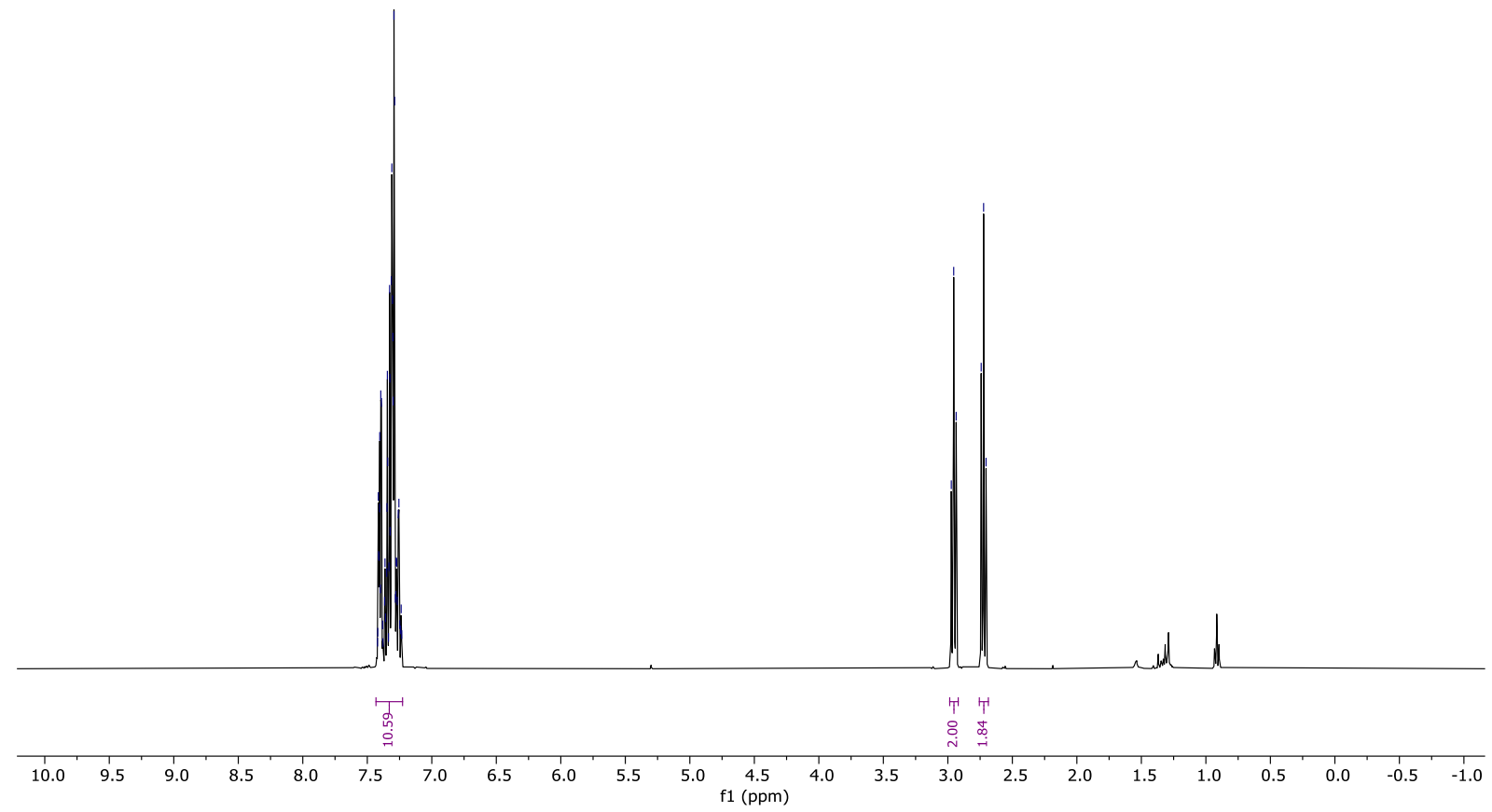

${ }^{13} \mathrm{C}$ NMR $\left(101 \mathrm{MHz}, \mathrm{CDCl}_{3}\right)$ of compound $4 \mathbf{a}$ :
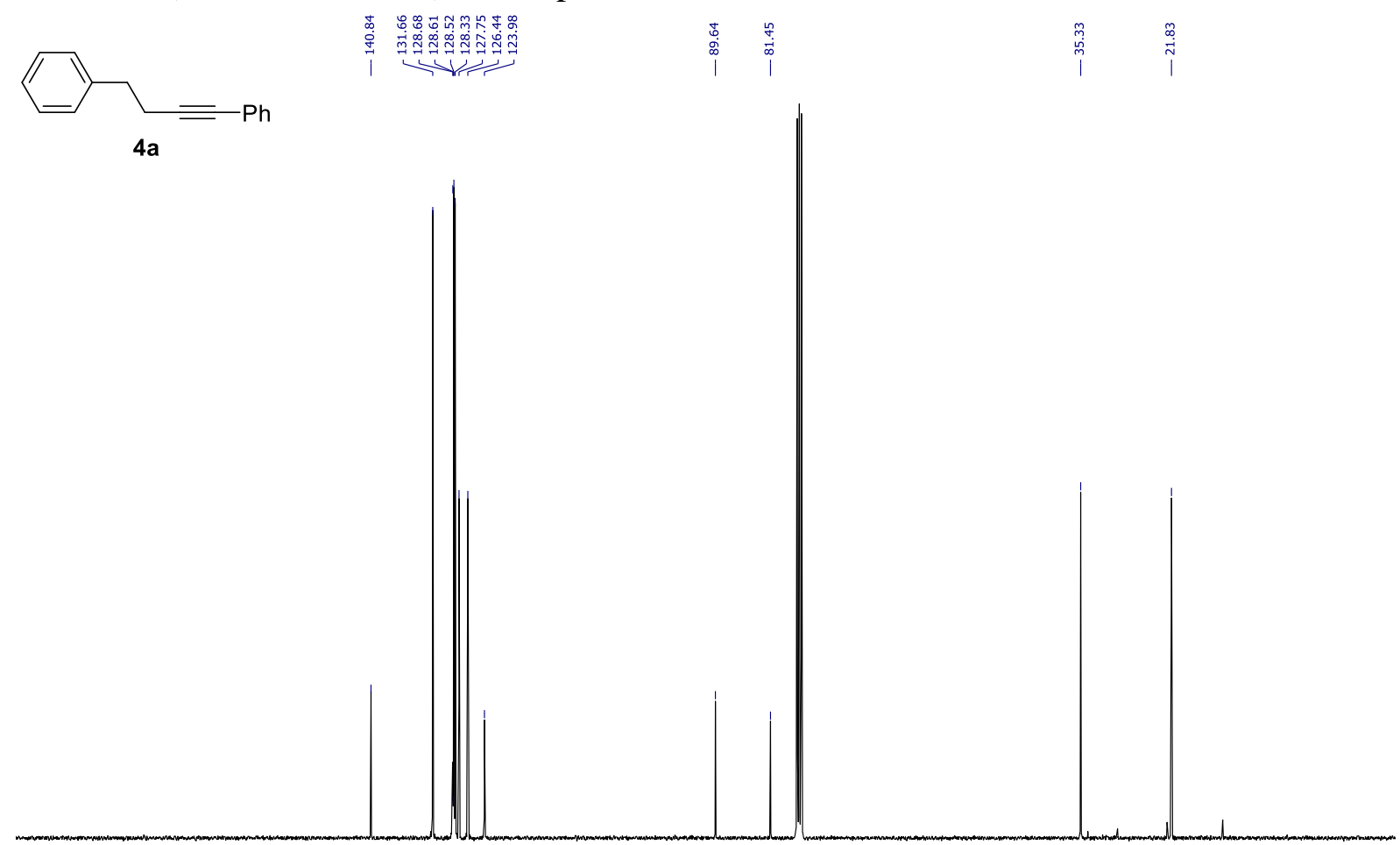
${ }^{1} \mathrm{H}$ NMR (400 MHz, $\mathrm{CDCl}_{3}$ ) of compound $\mathbf{4 b}$ :

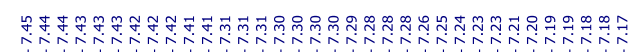

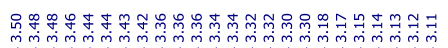

$\overbrace{4 b}=P h$
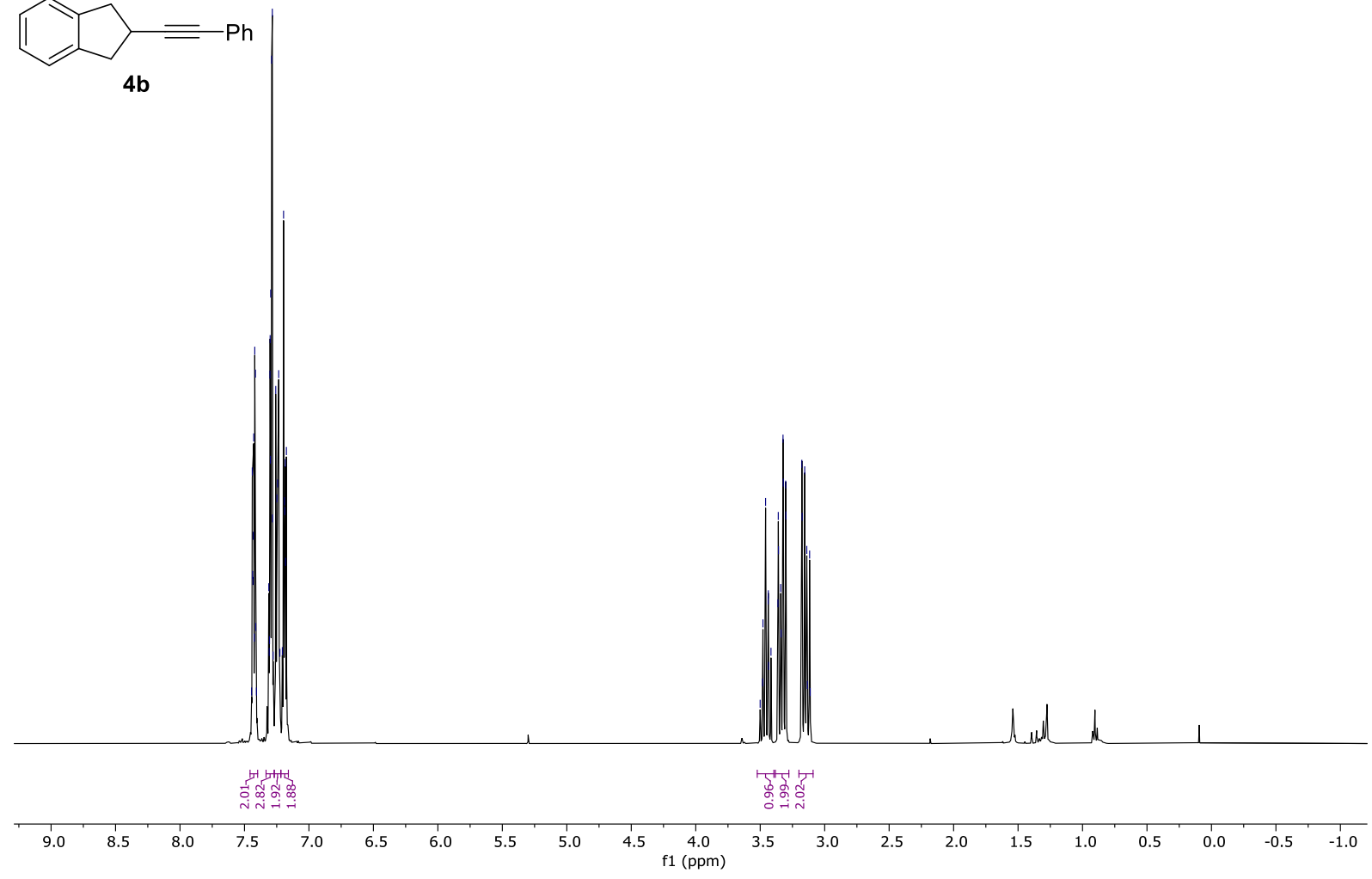

${ }^{13} \mathrm{C}$ NMR $\left(101 \mathrm{MHz}, \mathrm{CDCl}_{3}\right)$ of compound $\mathbf{4 b}$ :

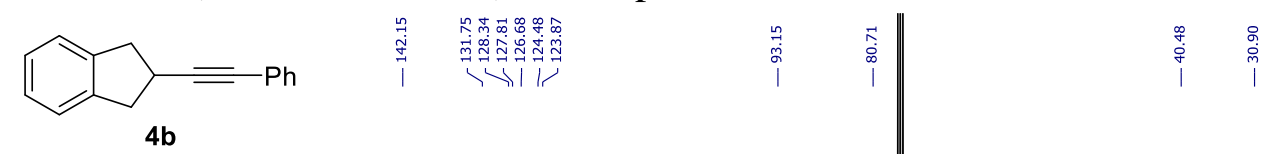

$4 b$

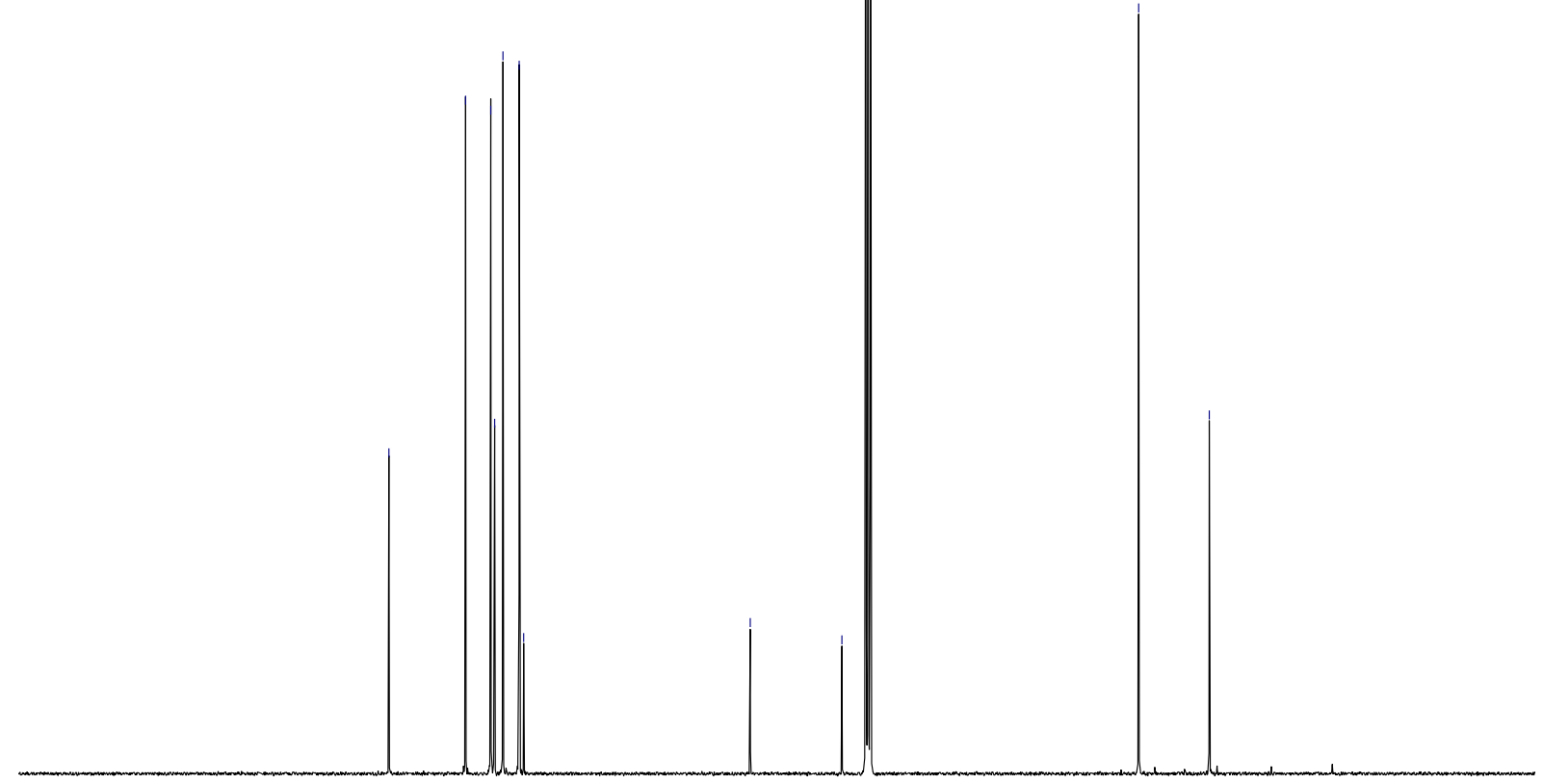

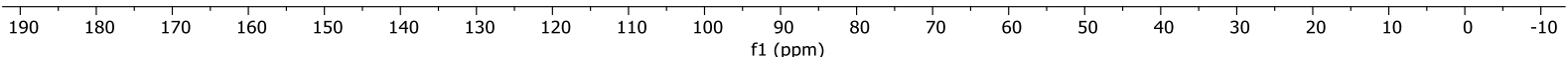


${ }^{1} \mathrm{H}$ NMR $\left(400 \mathrm{MHz}, \mathrm{CDCl}_{3}\right)$ of compound $\mathbf{4 c}$ :

学

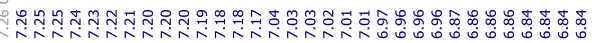

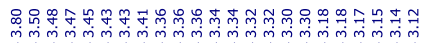

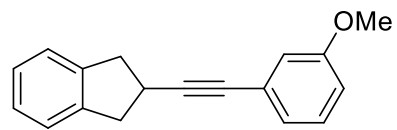

$4 c$

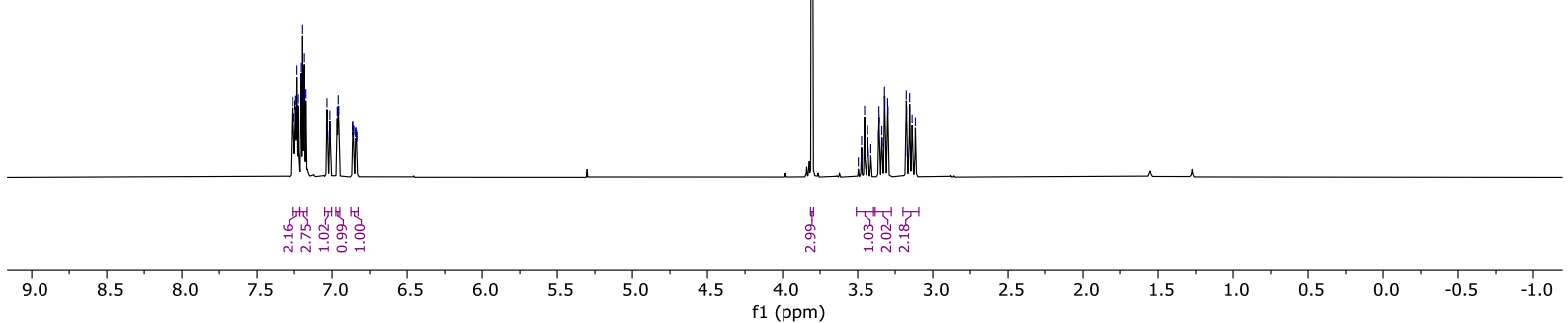

${ }^{13} \mathrm{C}$ NMR (101 MHz, $\mathrm{CDCl}_{3}$ ) of compound $4 \mathrm{c}$ :

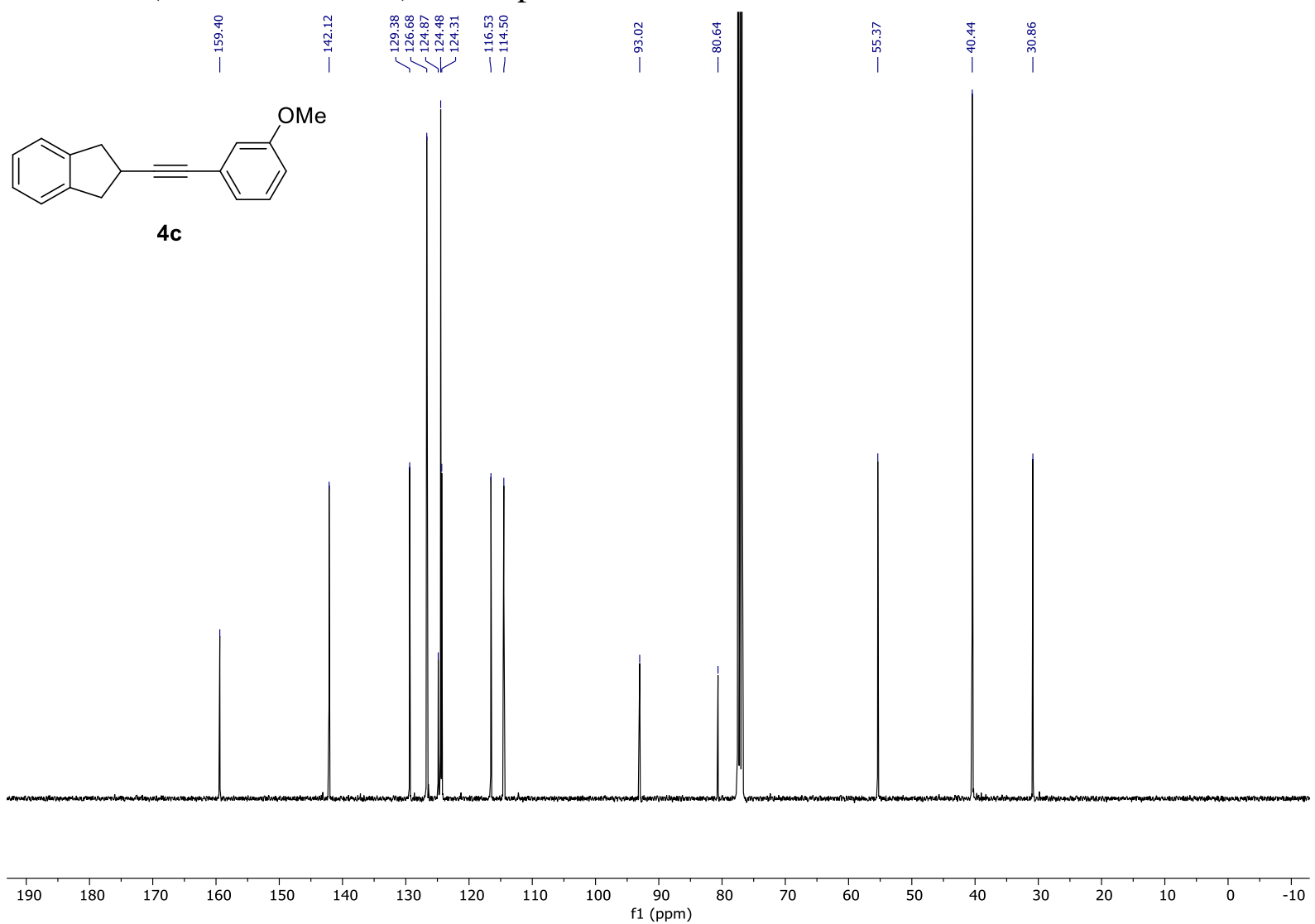

S64 
${ }^{1} \mathrm{H}$ NMR (400 MHz, $\mathrm{CDCl}_{3}$ ) of compound $\mathbf{4 d}$ :

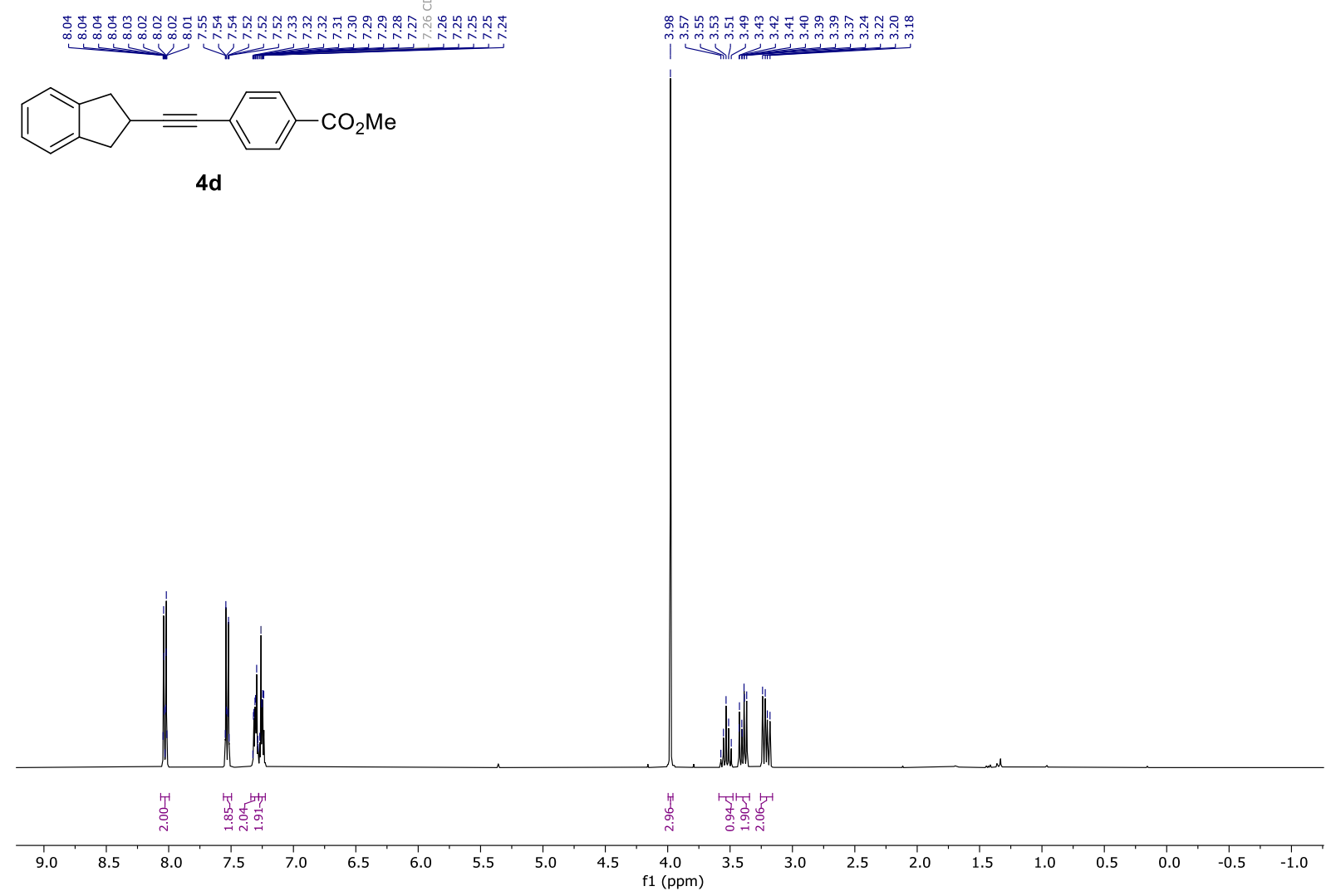

${ }^{13} \mathrm{C}$ NMR (101 MHz, $\left.\mathrm{CDCl}_{3}\right)$ of compound $\mathbf{4 d}$ :
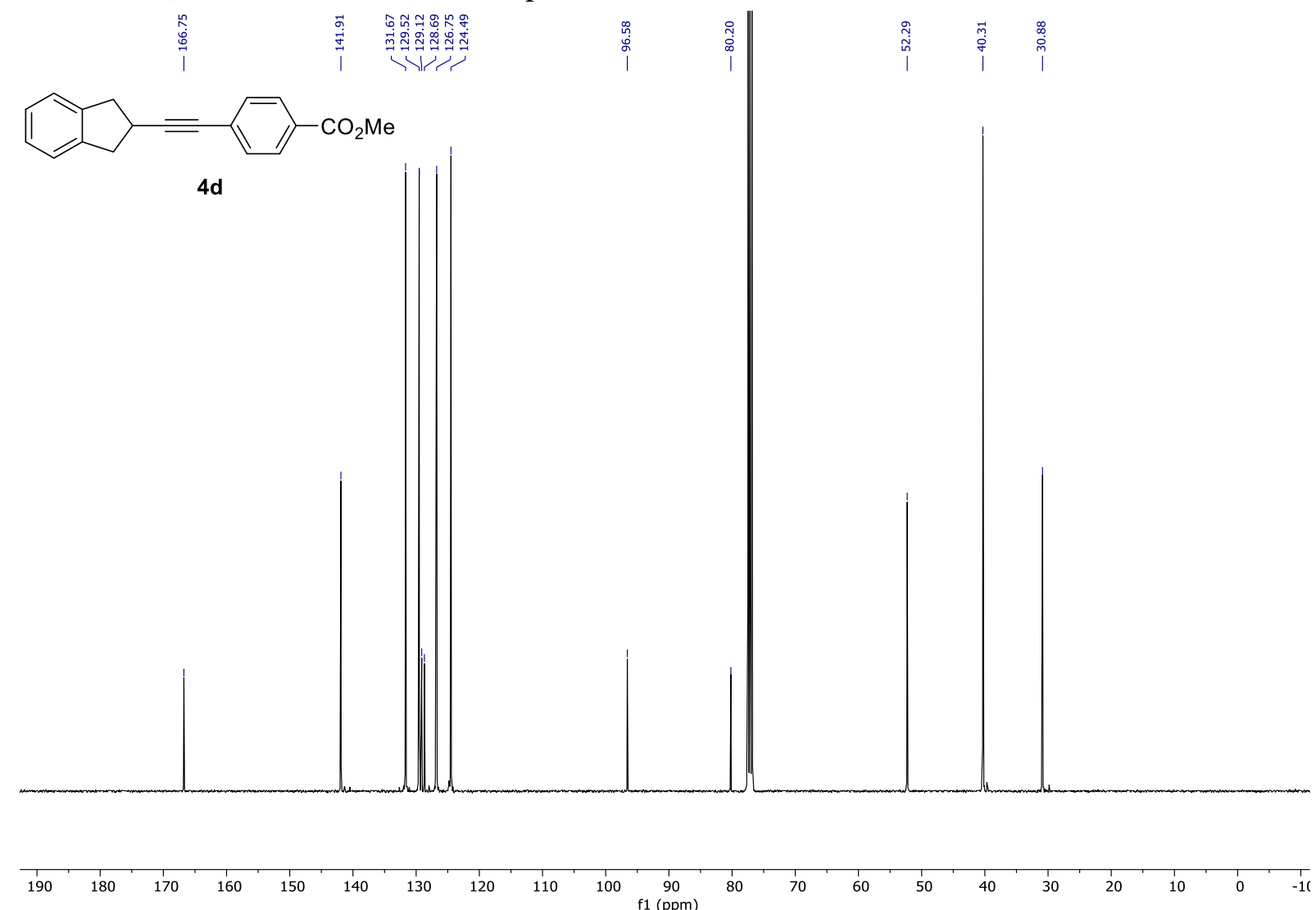
${ }^{1} \mathrm{H}$ NMR $\left(400 \mathrm{MHz}, \mathrm{CDCl}_{3}\right)$ of compound $4 \mathrm{e}$ :

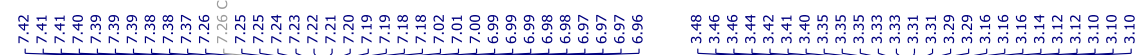

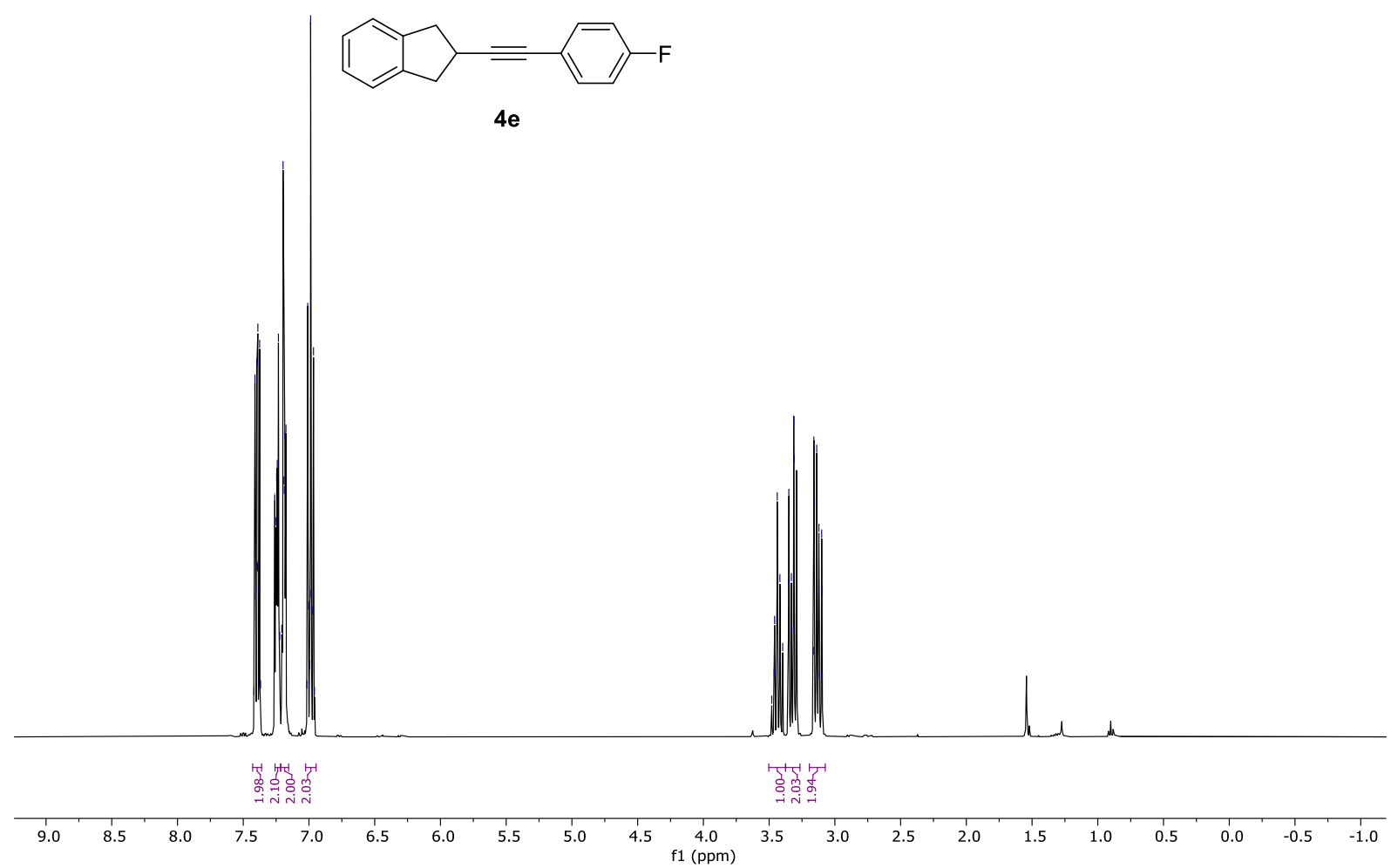

${ }^{13} \mathrm{C}$ NMR $\left(101 \mathrm{MHz}, \mathrm{CDCl}_{3}\right)$ of compound $4 \mathbf{e}$ :

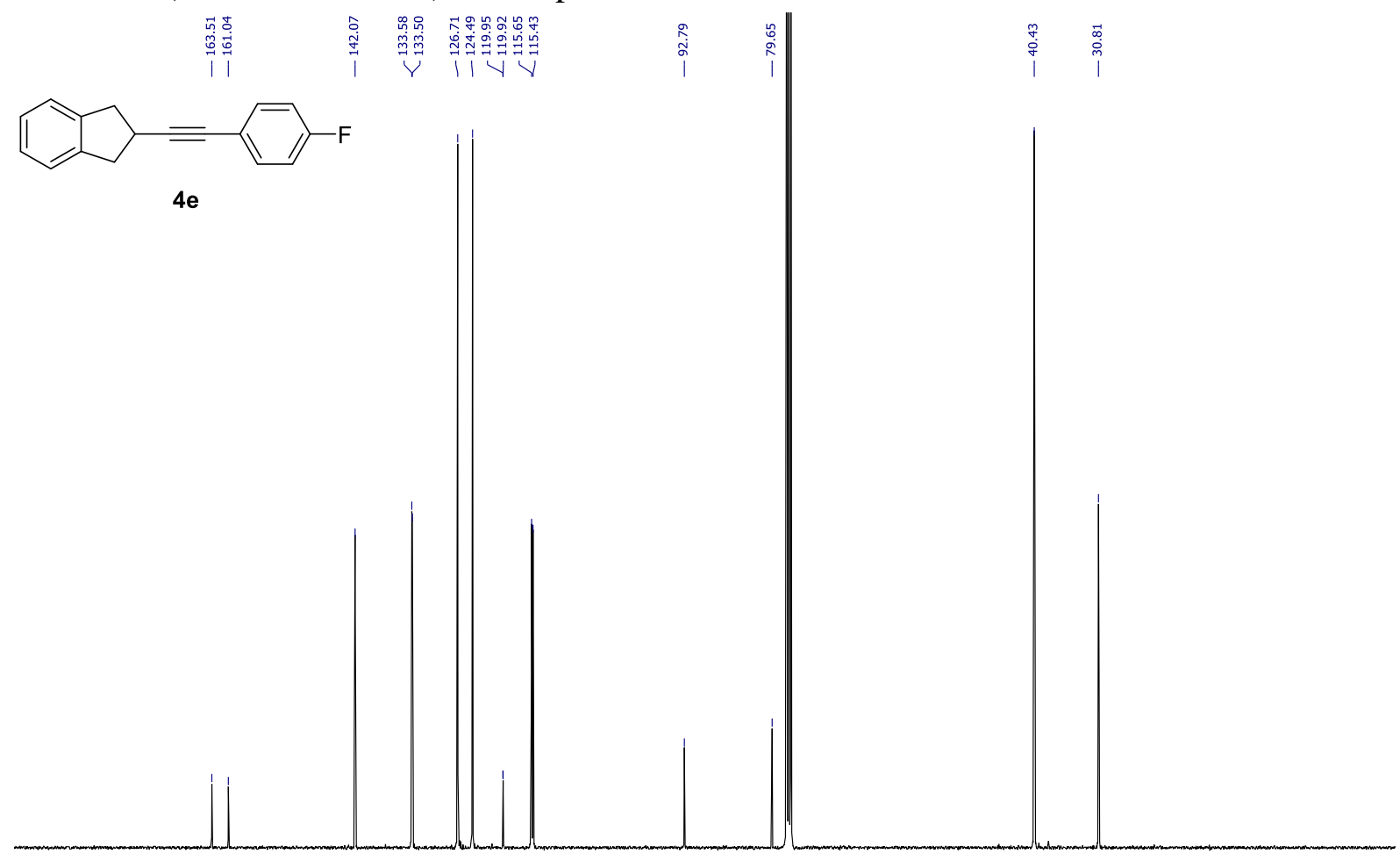

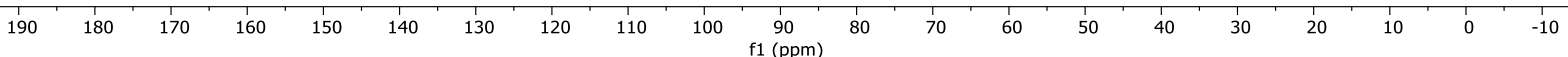


${ }^{19} \mathrm{~F}$ NMR $\left(376 \mathrm{MHz}, \mathrm{CDCl}_{3}\right)$ of compound $4 \mathrm{e}$ :

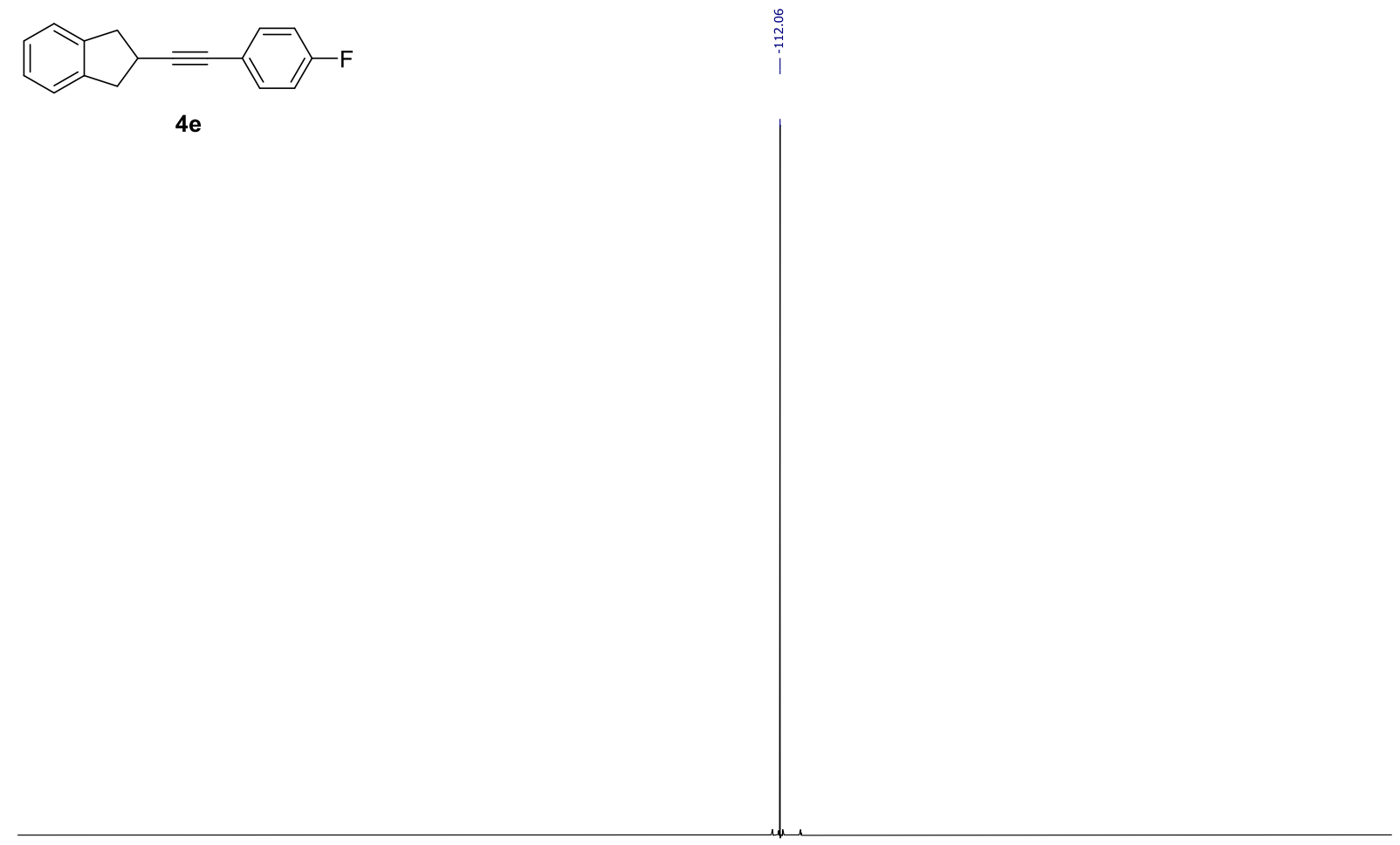

\begin{tabular}{llllllllllllllllllllllll}
\hline 10 & 0 & -10 & -20 & -30 & -40 & -50 & -60 & -70 & -80 & -90 & -100 & -110 & -120 & -130 & -140 & -150 & -160 & -170 & -180 & -190 & -200 & -211 \\
\hline
\end{tabular}

HRMS (APPI/LTQ-Orbitrap, positive mode) of compound 4e:

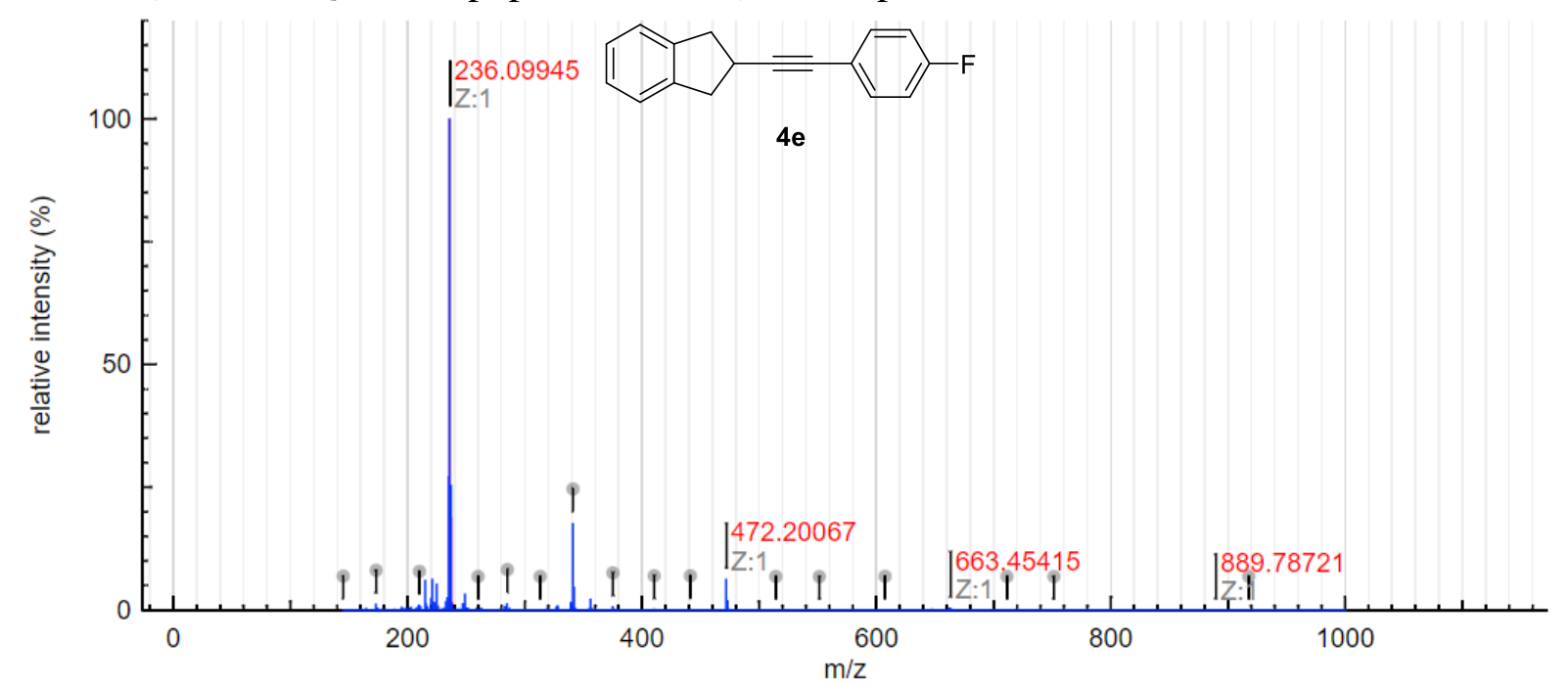


${ }^{1} \mathrm{H}$ NMR (400 MHz, $\mathrm{CDCl}_{3}$ ) of compound $\mathbf{4 f}$ :

要

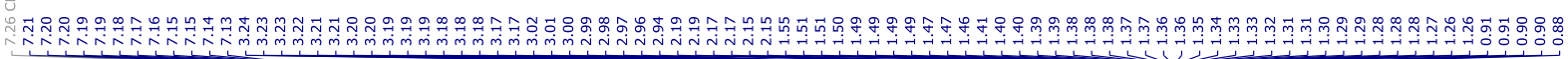

$1={ }^{n-\mathrm{Hex}}$
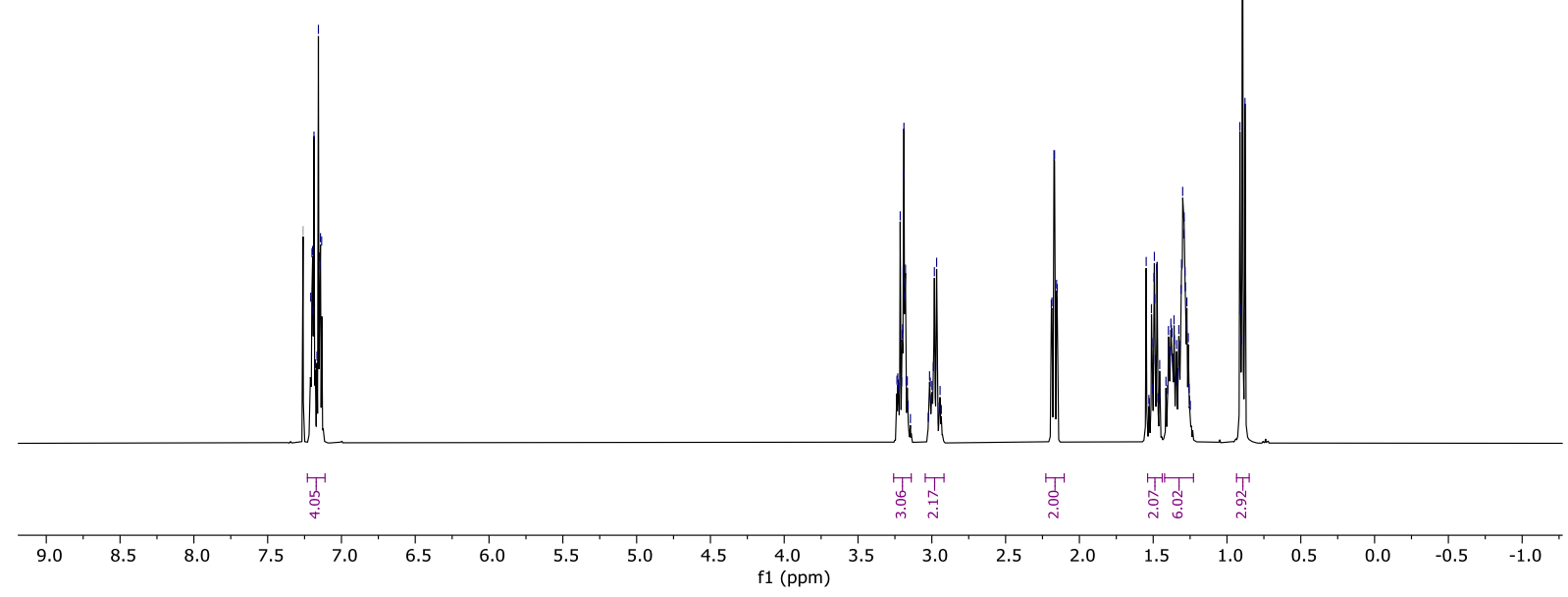

${ }^{13} \mathrm{C}$ NMR (101 MHz, $\left.\mathrm{CDCl}_{3}\right)$ of compound $4 \mathbf{4}$ :
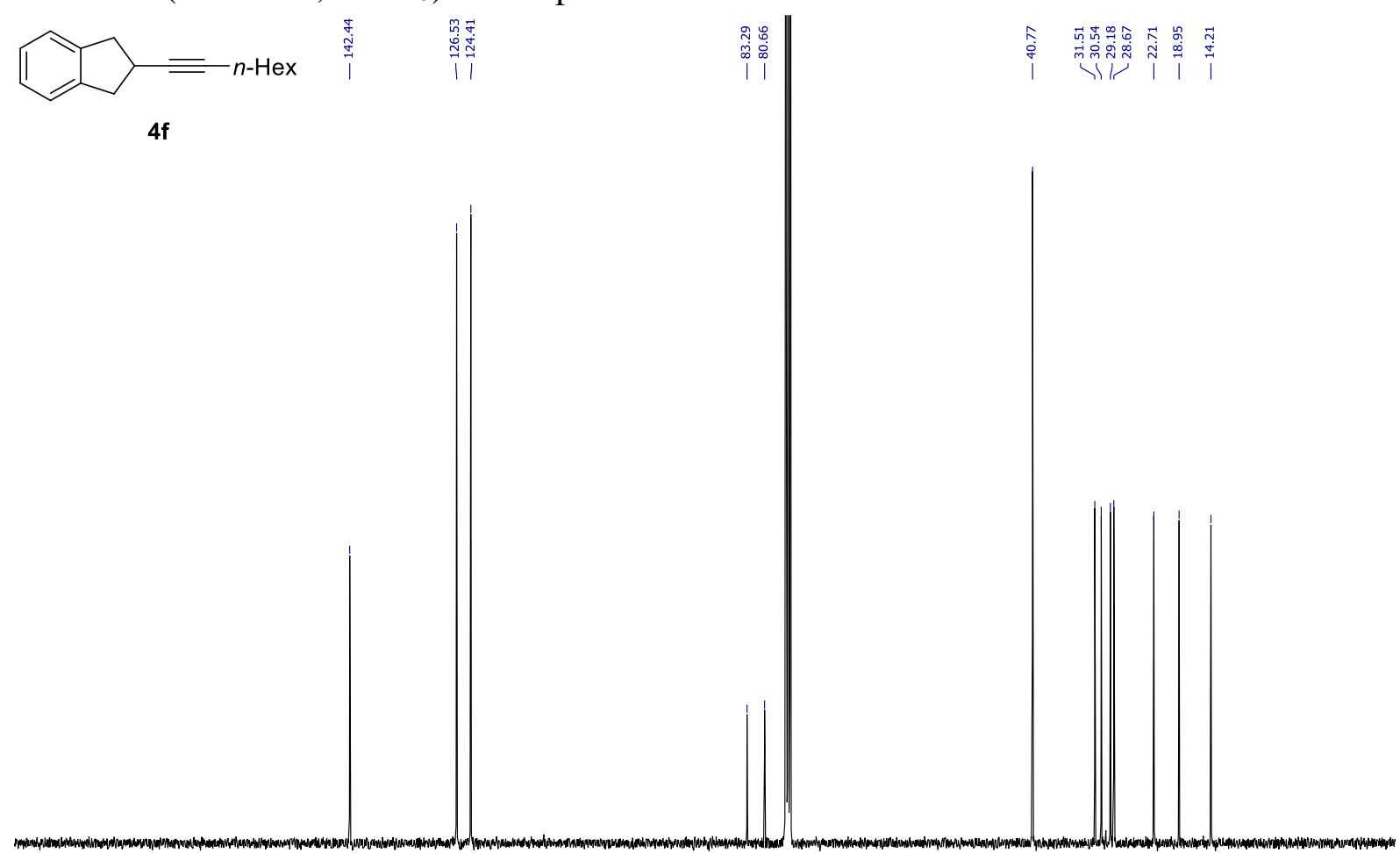

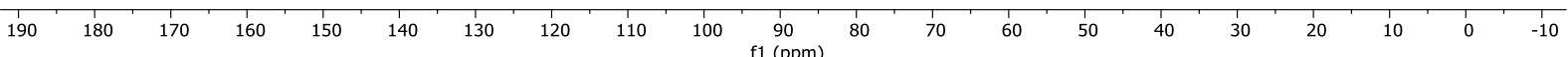


${ }^{1} \mathrm{H}$ NMR (400 MHz, $\mathrm{CDCl}_{3}$ ) of compound $\mathbf{4 g}$ :

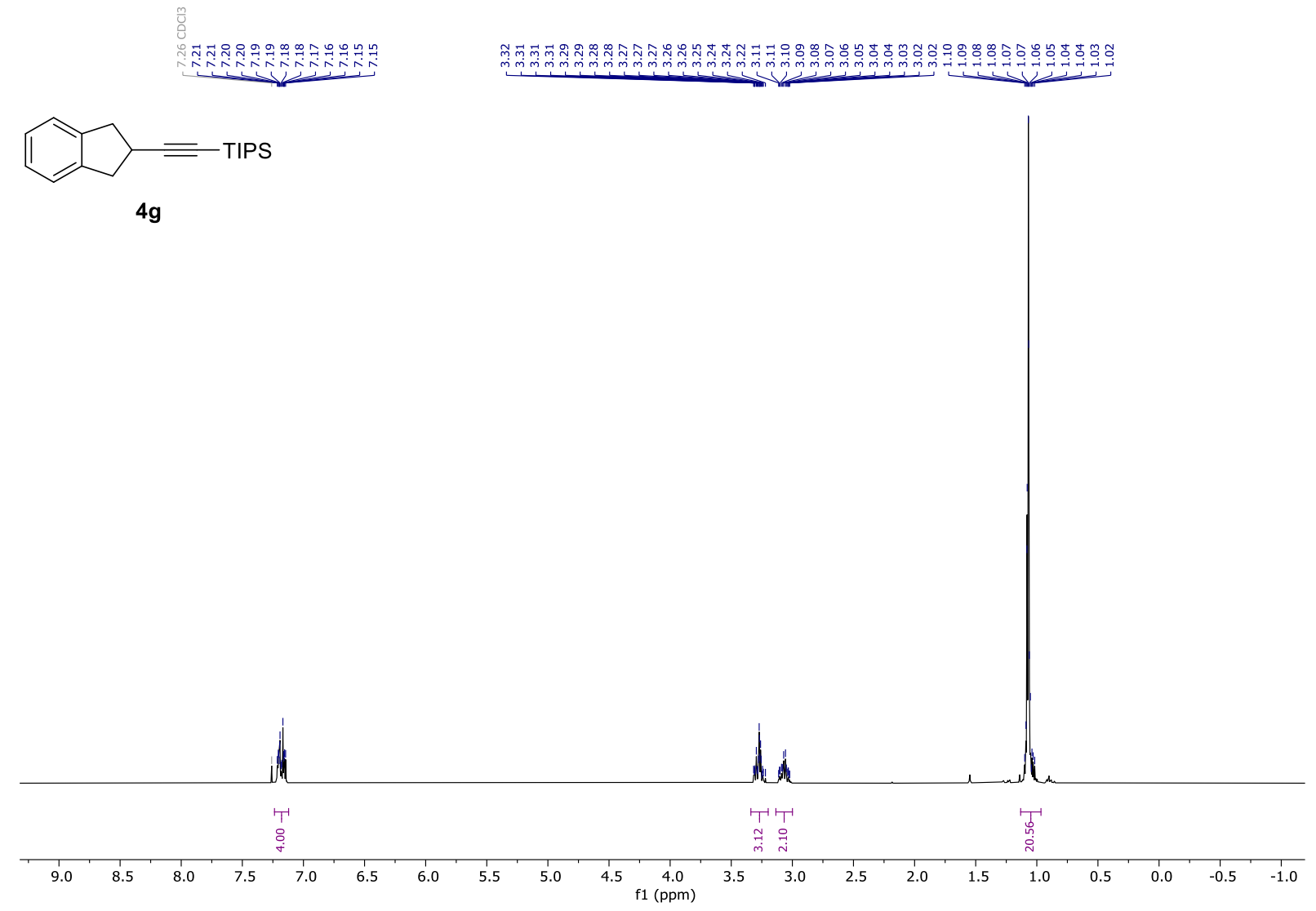

${ }^{13} \mathrm{C}$ NMR (101 MHz, $\left.\mathrm{CDCl}_{3}\right)$ of compound $\mathbf{4 g}$ :

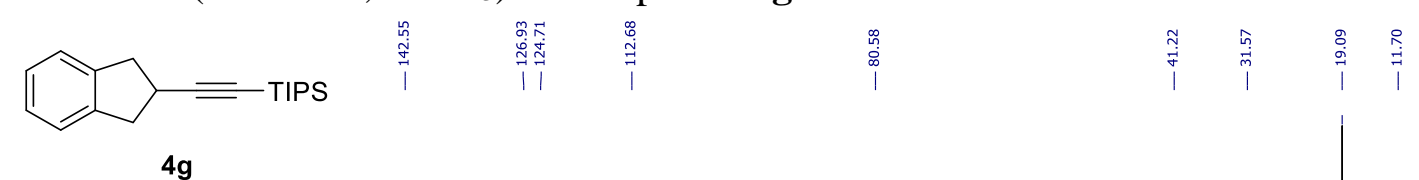

$4 g$

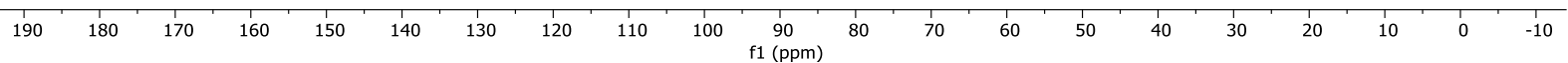


${ }^{1} \mathrm{H} \mathrm{NMR}$ (400 MHz, $\mathrm{CDCl}_{3}$ ) of compound $\mathbf{5 a}$ (purity determination):

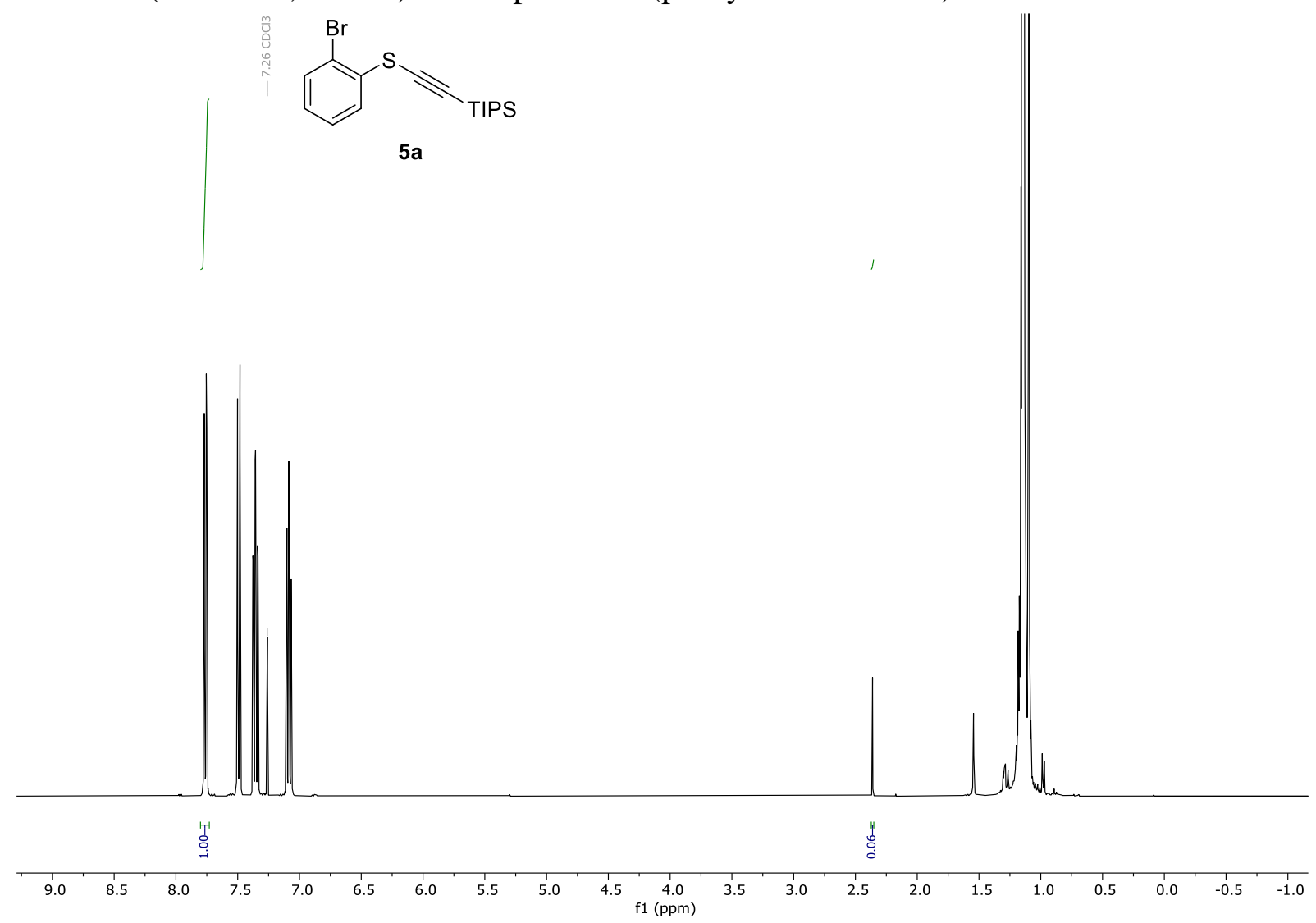

${ }^{1} \mathrm{H}$ NMR (400 MHz, $\mathrm{CDCl}_{3}$ ) of compound $\mathbf{5 a}$ :

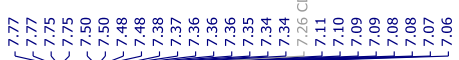

$\mathrm{Br}$<smiles>[Te]C#CCSc1ccccc1</smiles>

5a

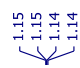

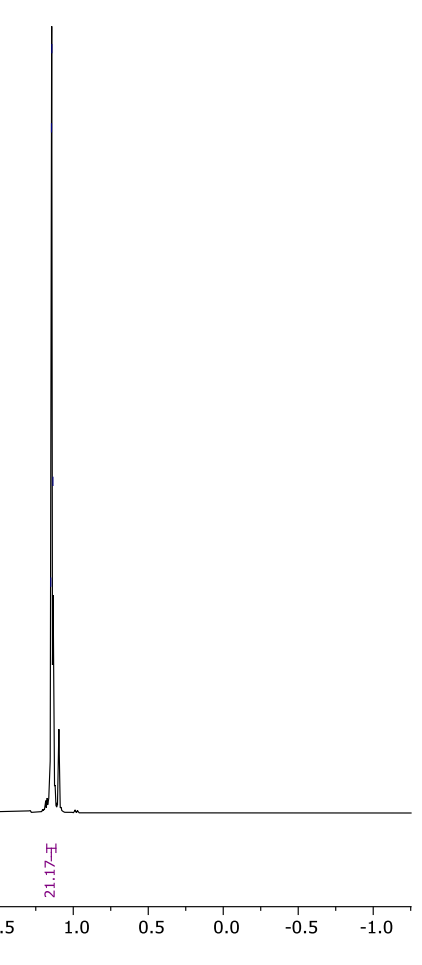


${ }^{13} \mathrm{C}$ NMR (101 MHz, $\mathrm{CDCl}_{3}$ ) of compound 5a:
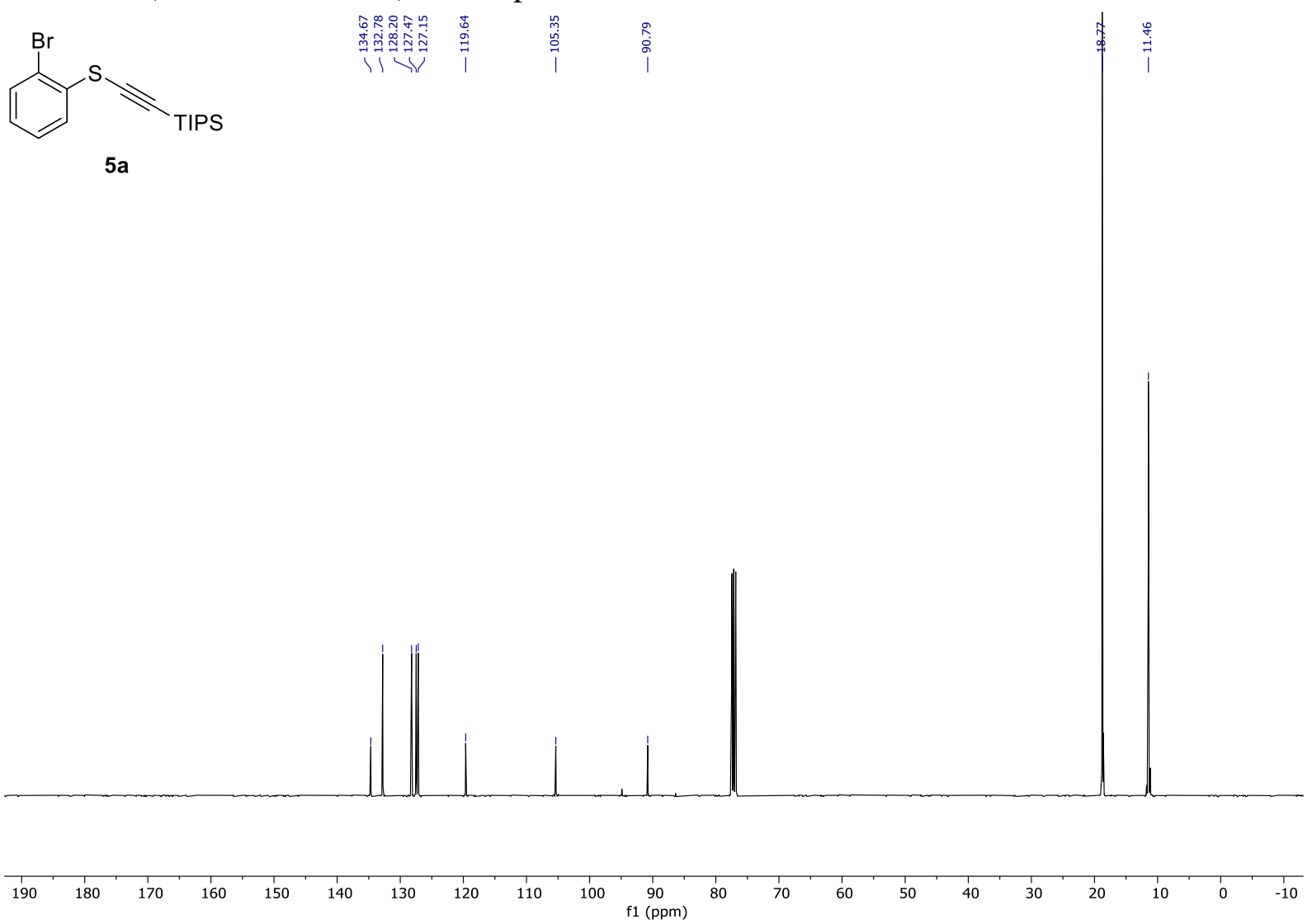

${ }^{1} \mathrm{H}$ NMR (400 MHz, $\mathrm{CDCl}_{3}$ ) of compound $\mathbf{5 b}$ :

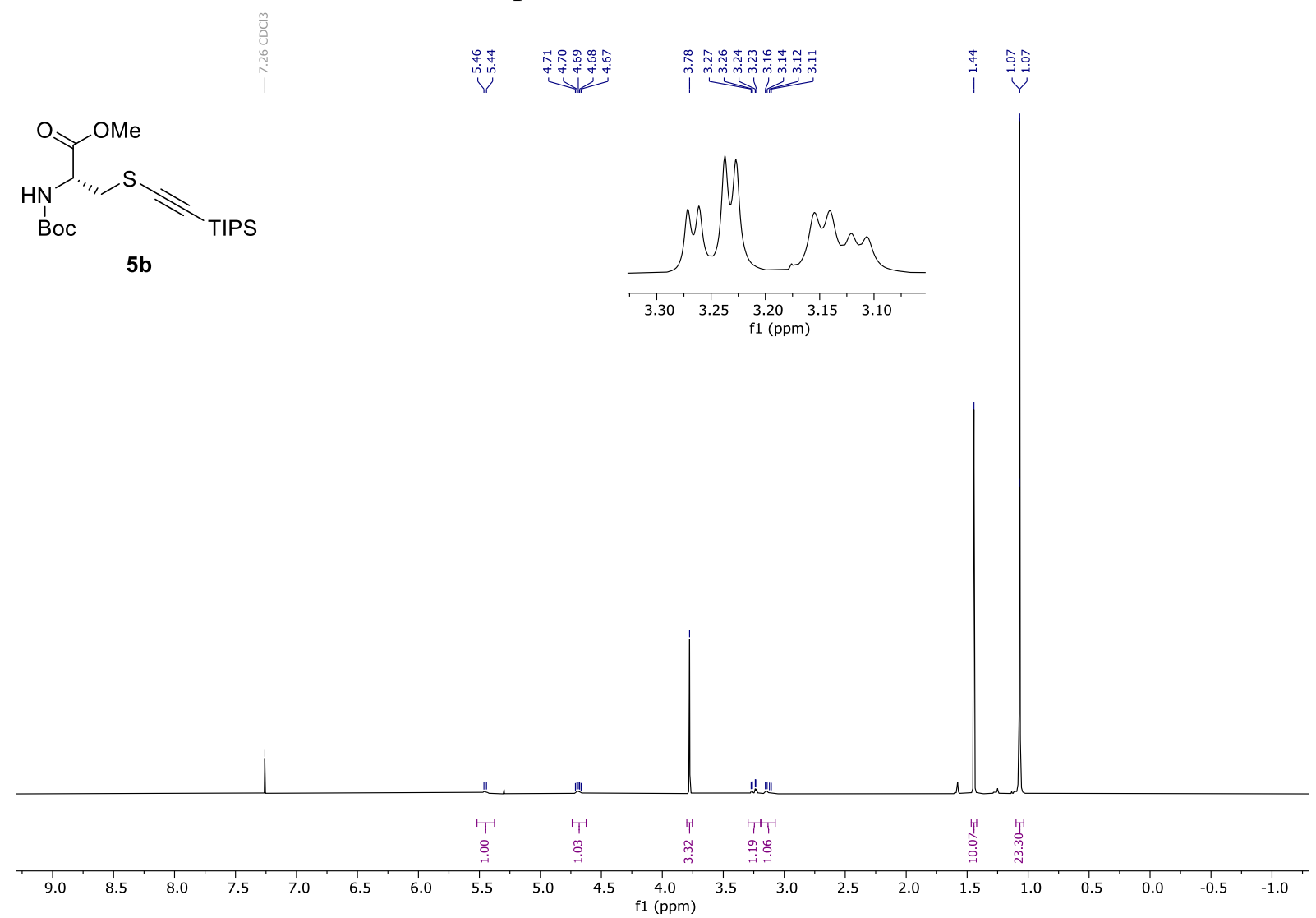


${ }^{13} \mathrm{C}$ NMR (101 MHz, $\mathrm{CDCl}_{3}$ ) of compound $\mathbf{5 b}$ :

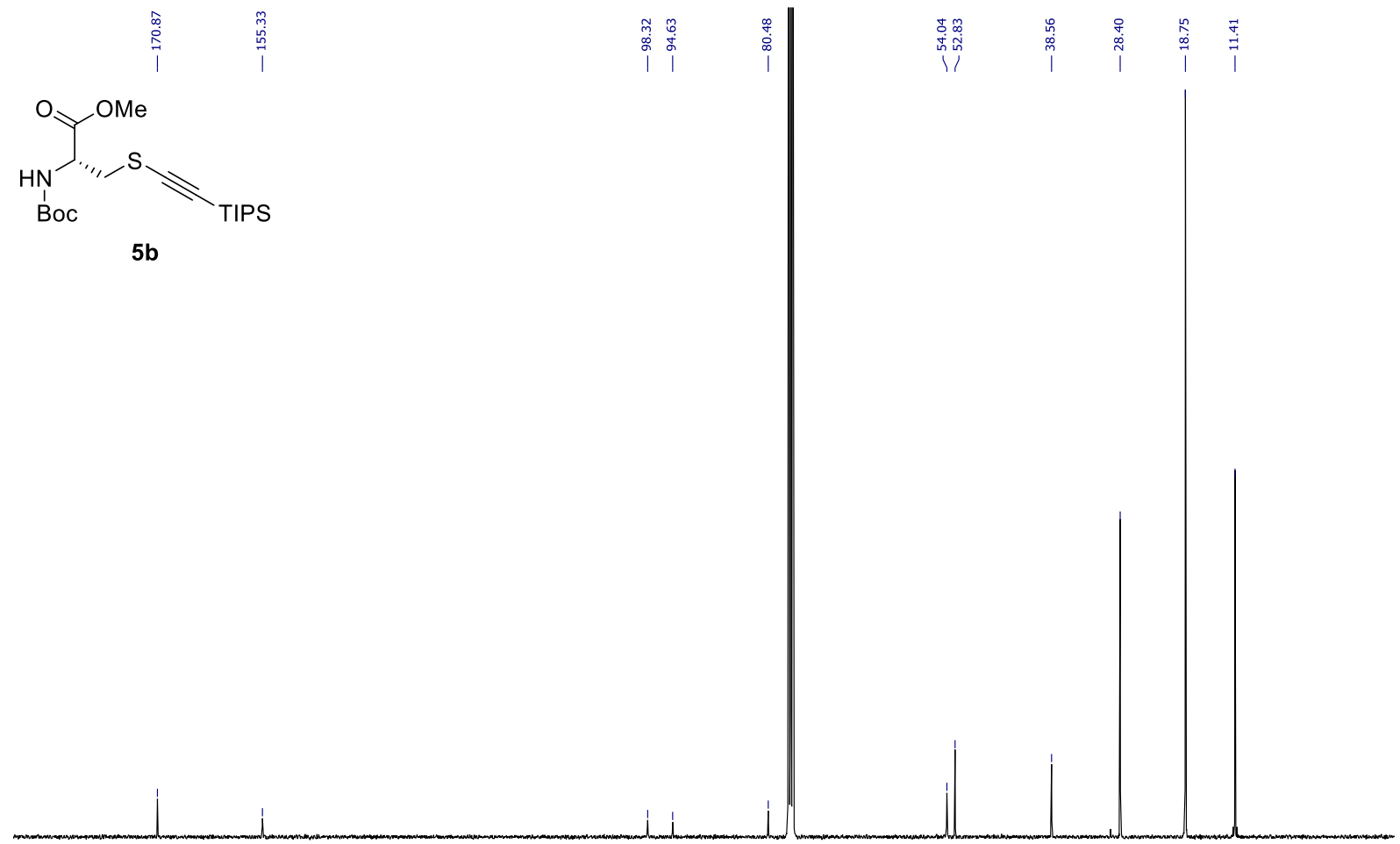

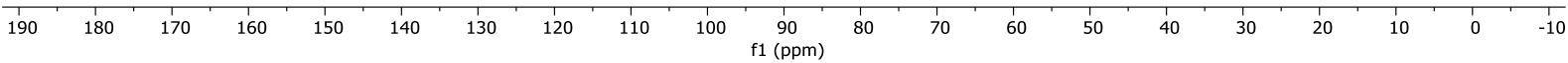

${ }^{1} \mathrm{H}$ NMR (400 MHz, $\mathrm{CDCl}_{3}$ ) of compound $\mathbf{5 c}$ :

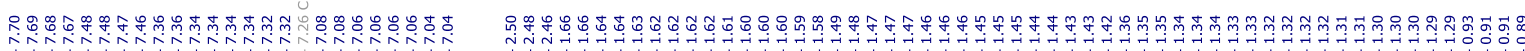

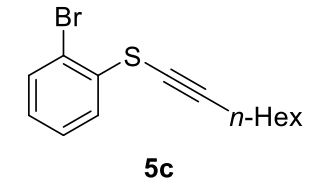

$5 c$
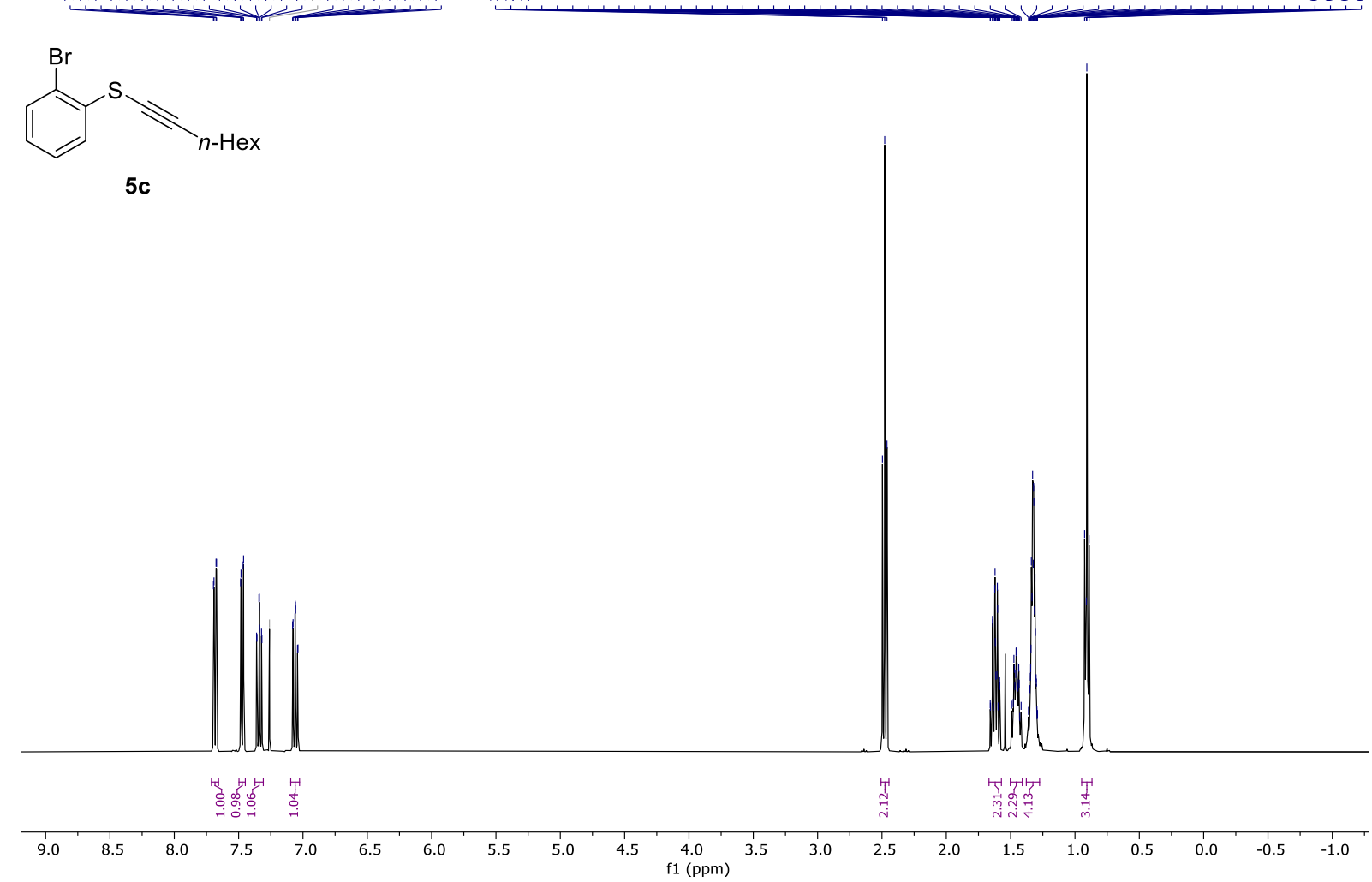
${ }^{13} \mathrm{C}$ NMR (101 MHz, $\mathrm{CDCl}_{3}$ ) of compound $\mathbf{5 c}$ :<smiles>O=COC#CSc1ccccc1Br</smiles>

$5 c$
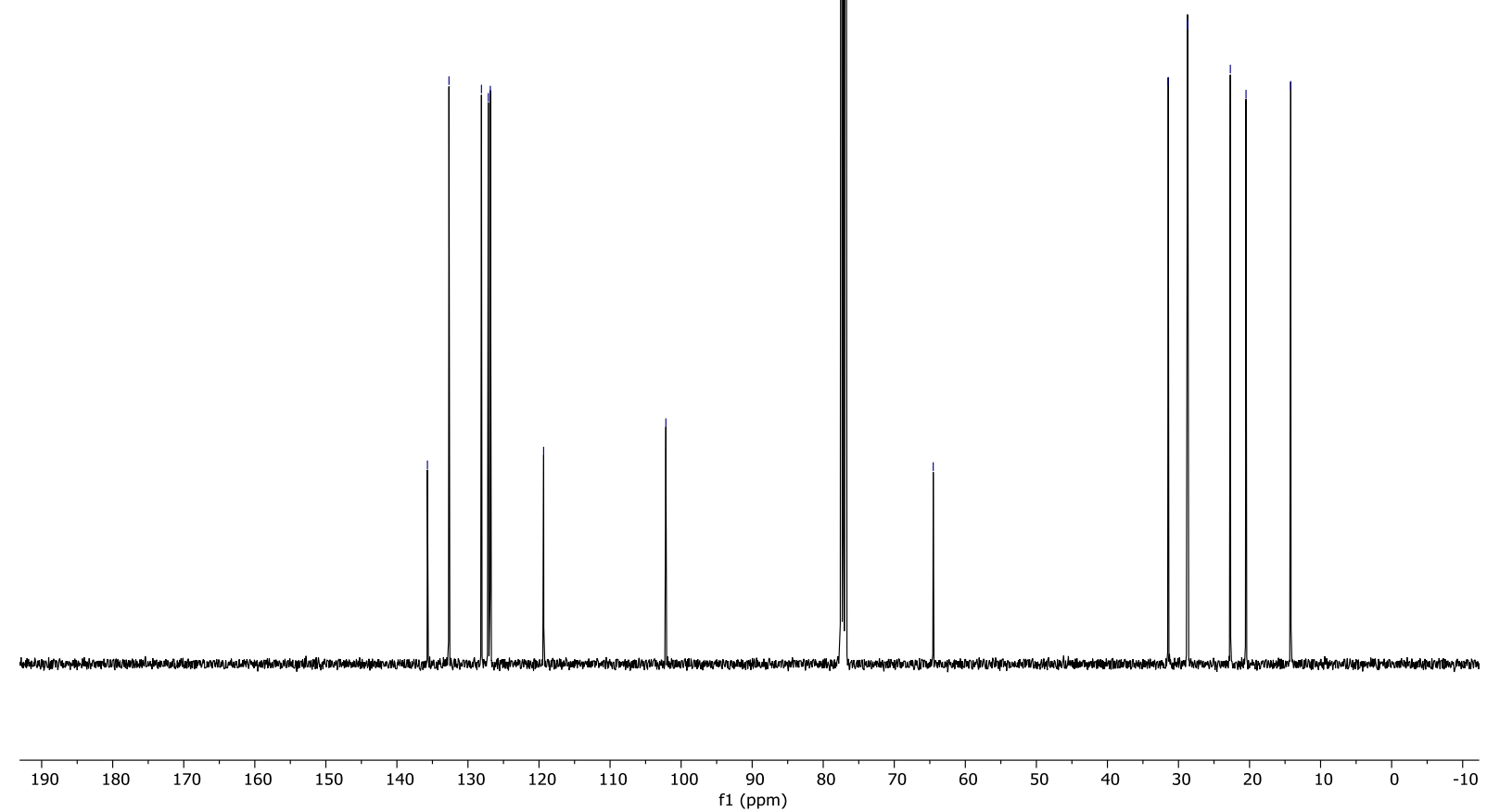

${ }^{1} \mathrm{H}$ NMR (400 MHz, $\mathrm{CDCl}_{3}$ ) of compound $\mathbf{5 d}$ :

年

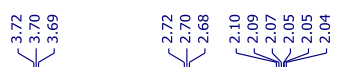

$\mathrm{Br}$<smiles>ClCCCC#CSc1ccccc1Cl</smiles>

$5 d$
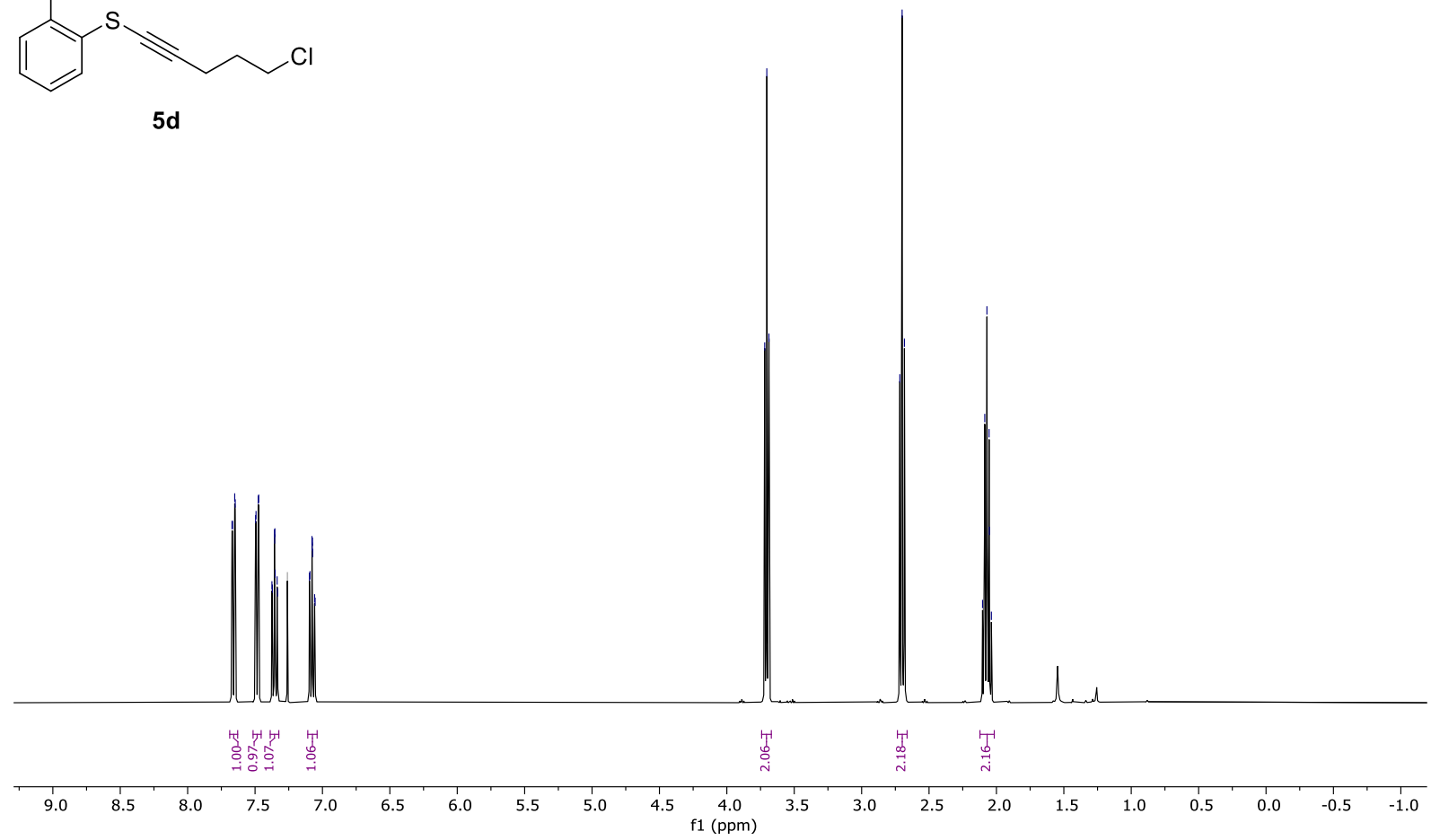
${ }^{13} \mathrm{C}$ NMR $\left(101 \mathrm{MHz}, \mathrm{CDCl}_{3}\right)$ of compound $\mathbf{5 d}$ :

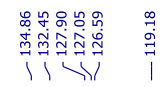

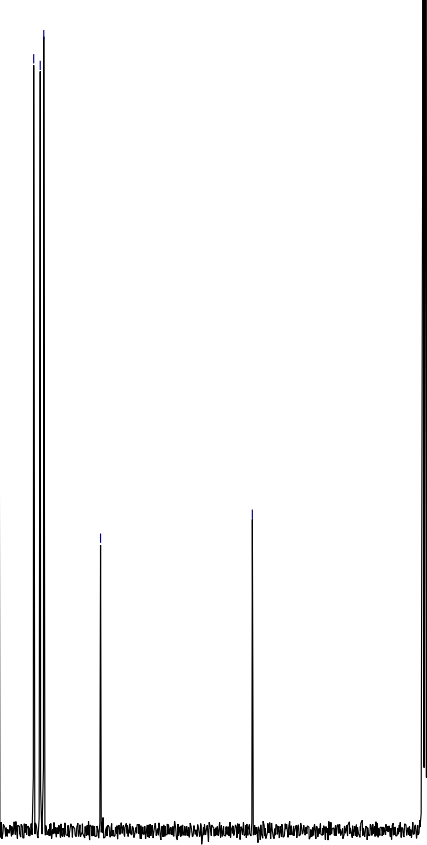

\%ి

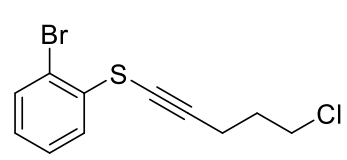

$5 d$

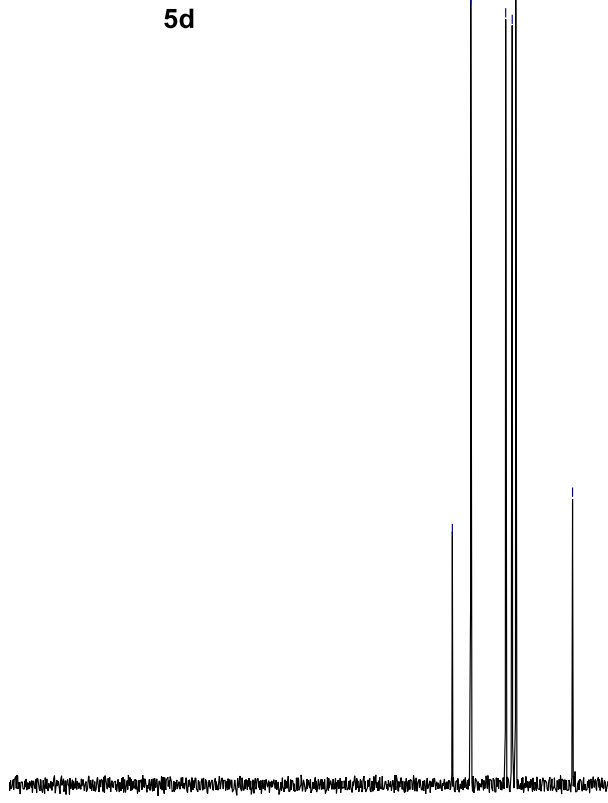

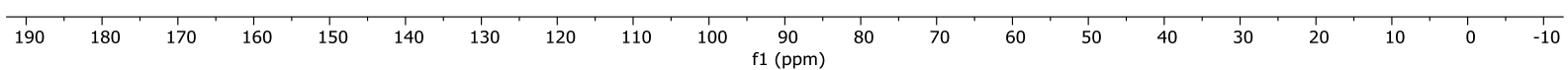

${ }^{1} \mathrm{H} \mathrm{NMR}\left(400 \mathrm{MHz}, \mathrm{CDCl}_{3}\right)$ of compound $\mathbf{5 e}$ :

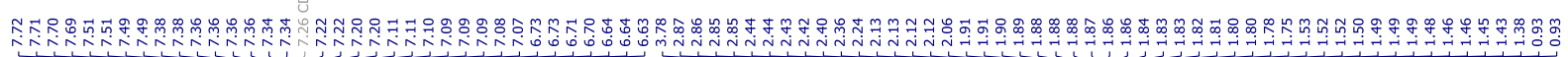
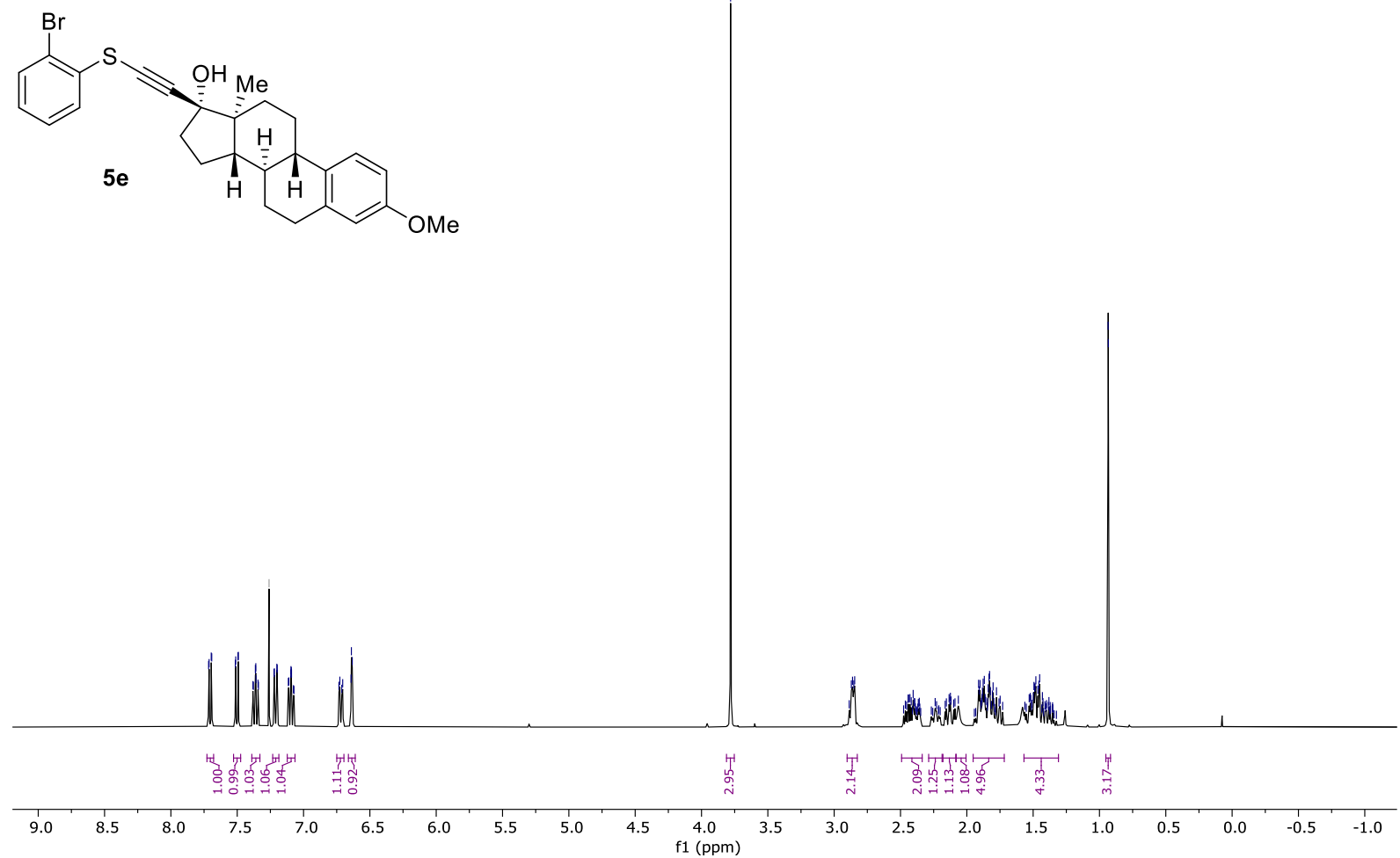

S74 
${ }^{13} \mathrm{C} \mathrm{NMR}\left(101 \mathrm{MHz}, \mathrm{CDCl}_{3}\right)$ of compound $\mathbf{5 e}$

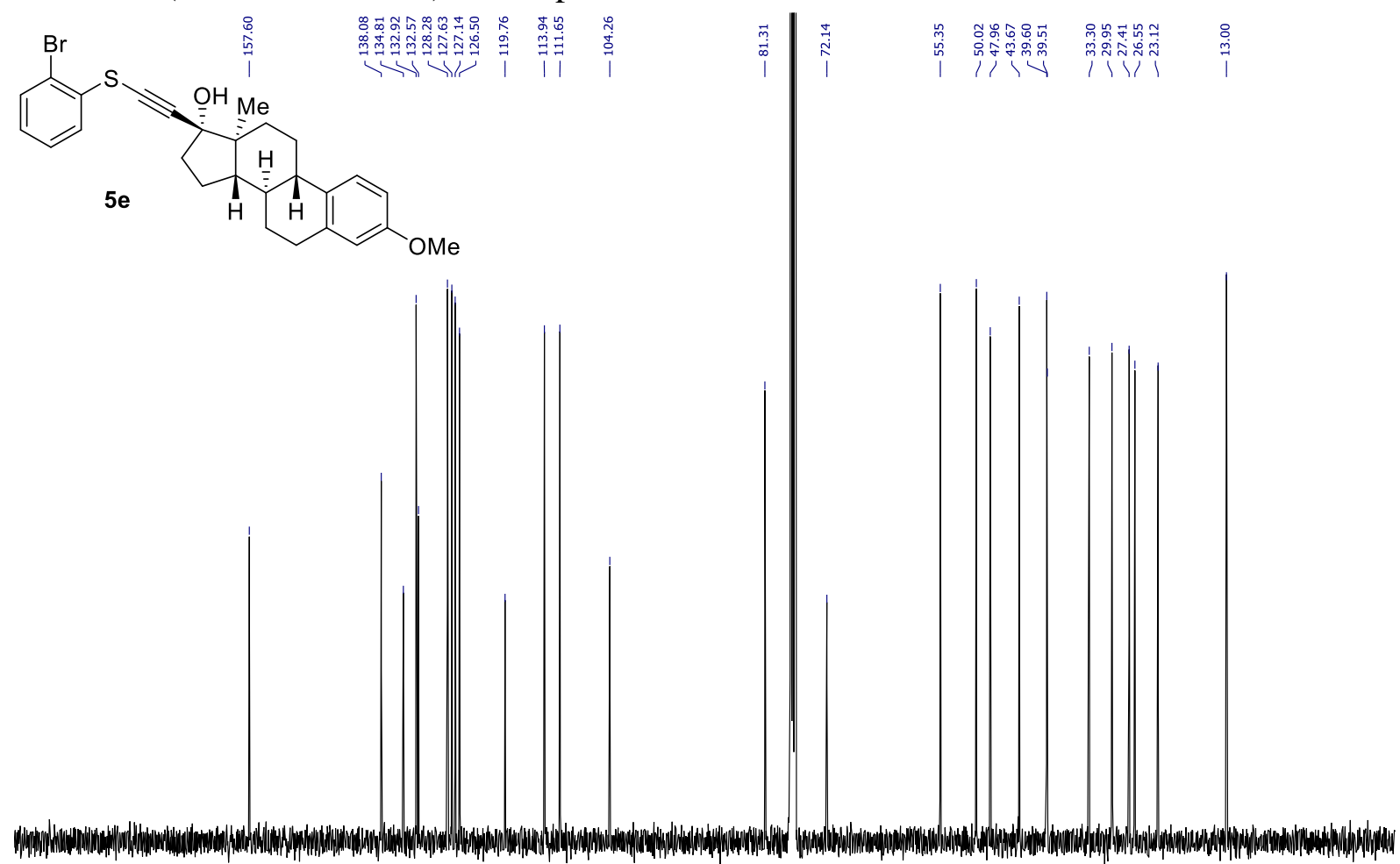

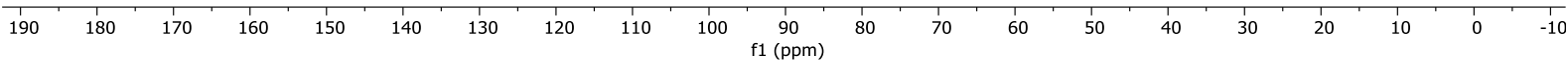

${ }^{1} \mathrm{H}$ NMR (400 MHz, $\mathrm{CDCl}_{3}$ ) of compound $\mathbf{5 f}$ :

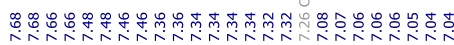

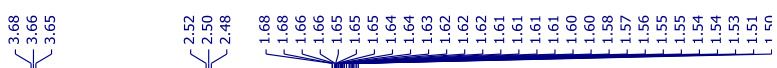

$\mathrm{Br}$<smiles>Cc1ccccc1SC#C[As]O</smiles>

$5 f$

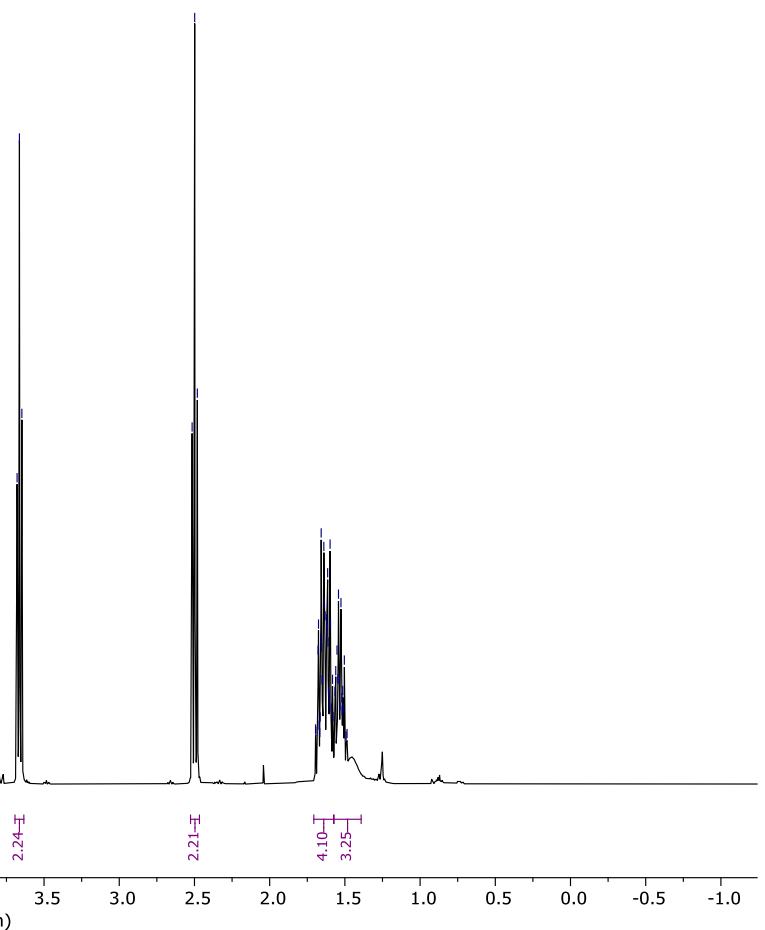


${ }^{13} \mathrm{C} \mathrm{NMR}\left(101 \mathrm{MHz}, \mathrm{CDCl}_{3}\right)$ of compound $\mathbf{5 f}$ :
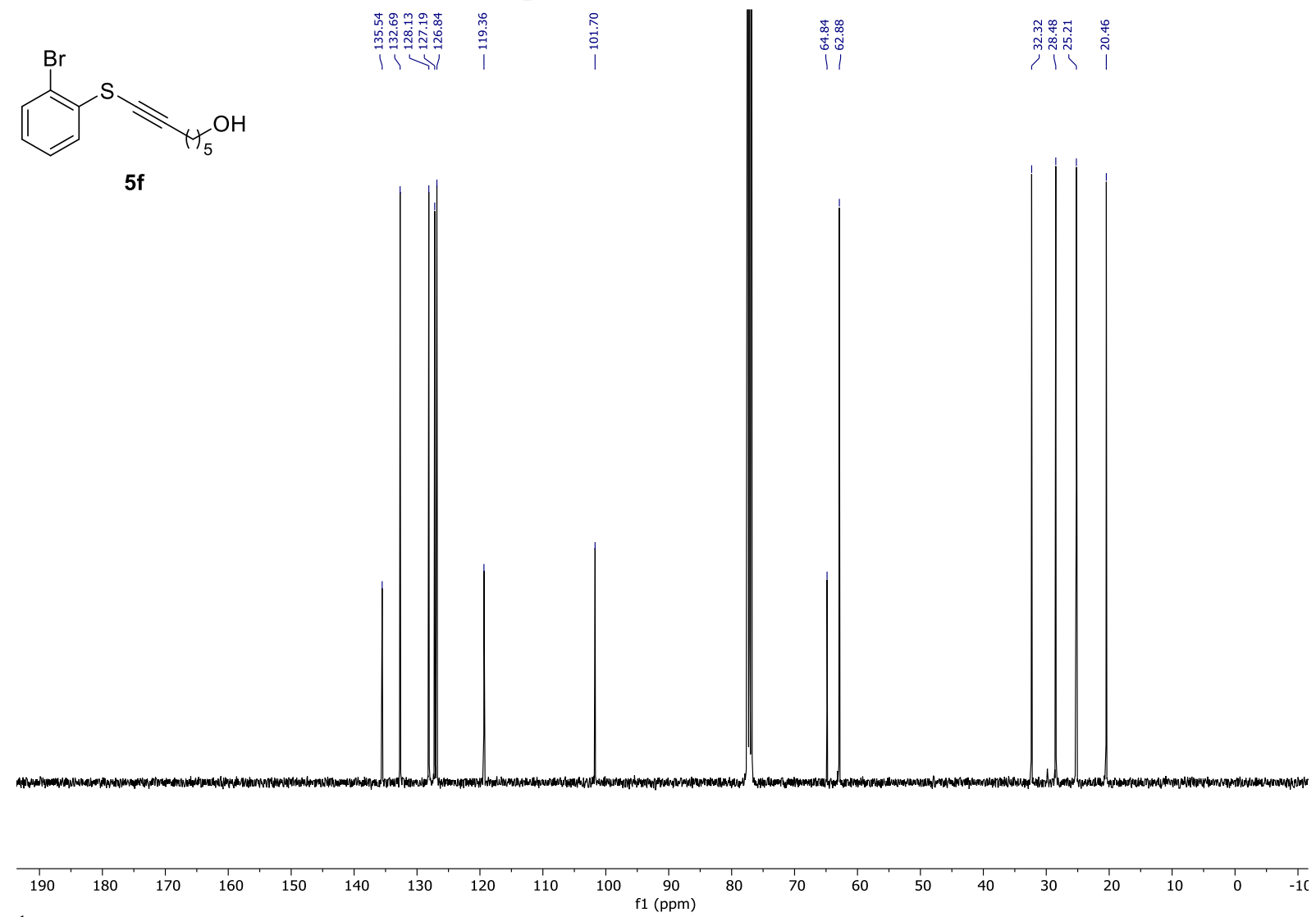

${ }^{1} \mathrm{H}$ NMR (400 MHz, $\mathrm{CDCl}_{3}$ ) of compound 7:

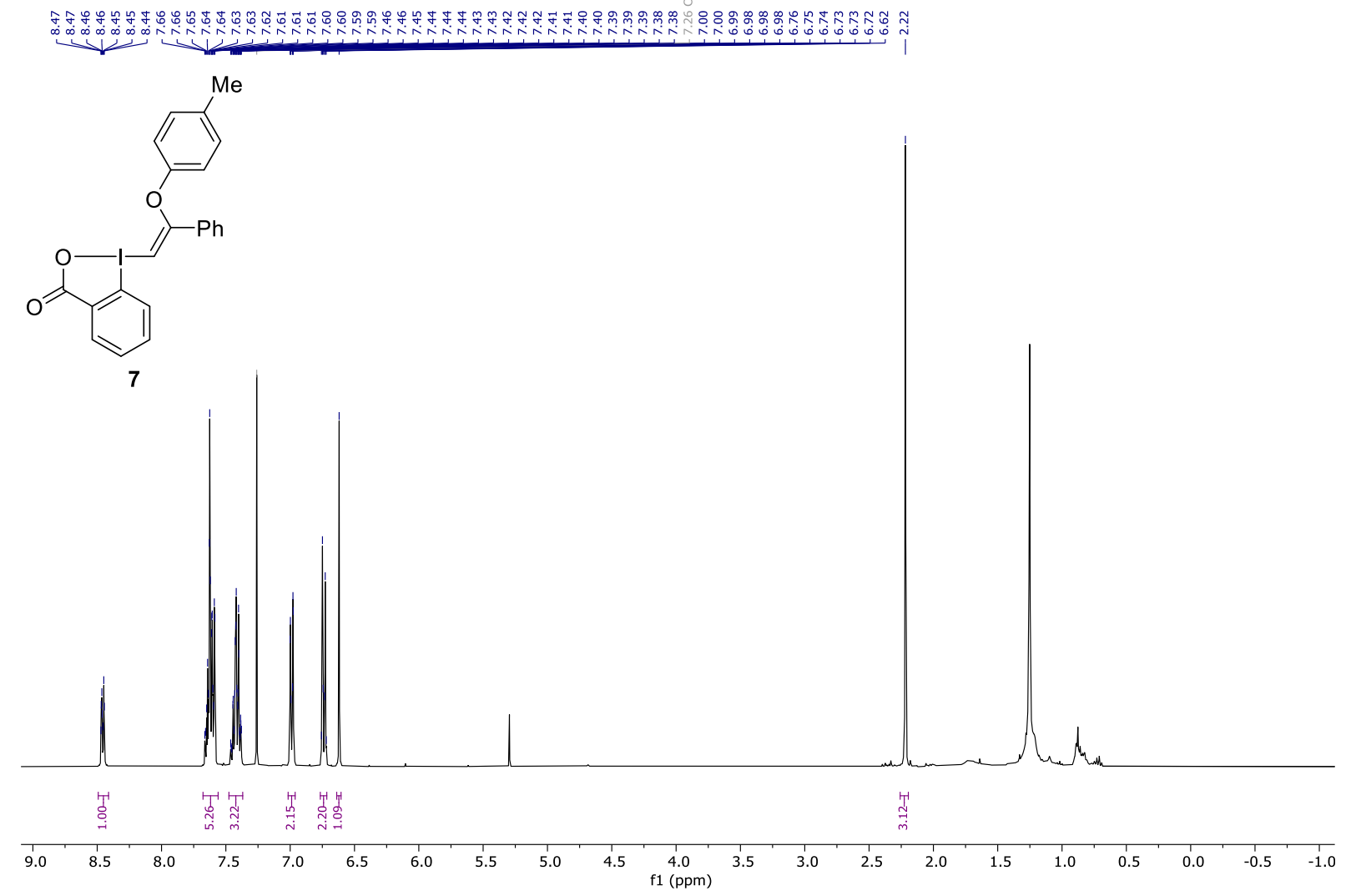


${ }^{13} \mathrm{C}$ NMR (101 MHz, $\left.\mathrm{CDCl}_{3}\right)$ of compound 7:

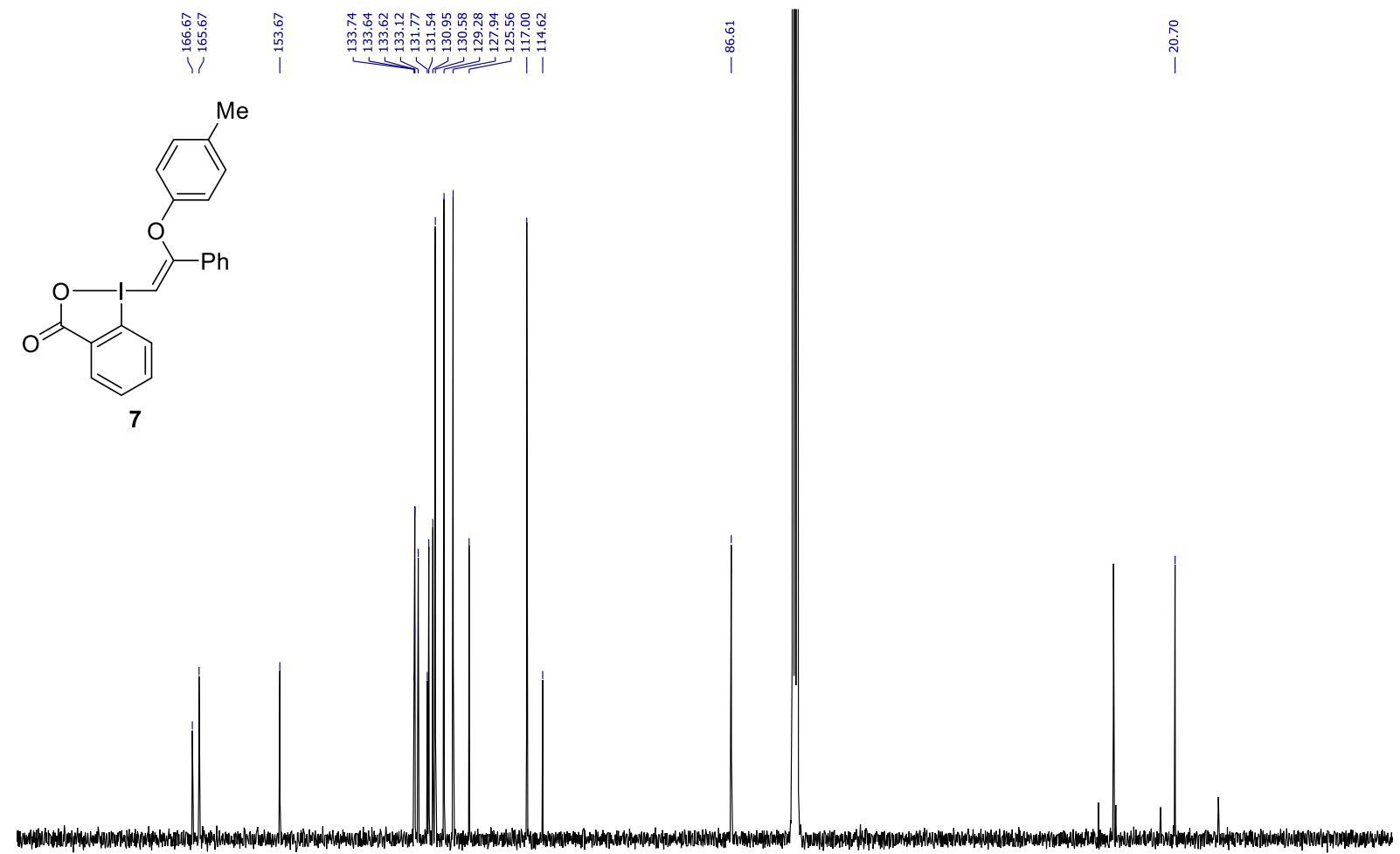

\begin{tabular}{r|llllllllllllllllllllll}
1 & 190 & 180 & 170 & 160 & 150 & 140 & 130 & 120 & 110 & 100 & $\underset{f 1}{90}$ & 80 & 70 & 60 & 50 & 40 & 30 & 20 & 10 & 0 & -16
\end{tabular}

${ }^{1} \mathrm{H}$ NMR (400 MHz, $\mathrm{CDCl}_{3}$ ) of compound $\mathbf{8}$ :

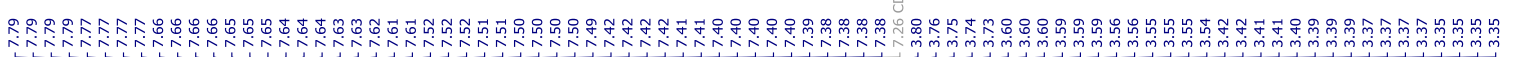

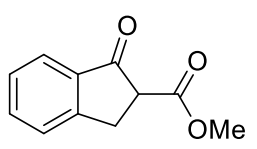

8

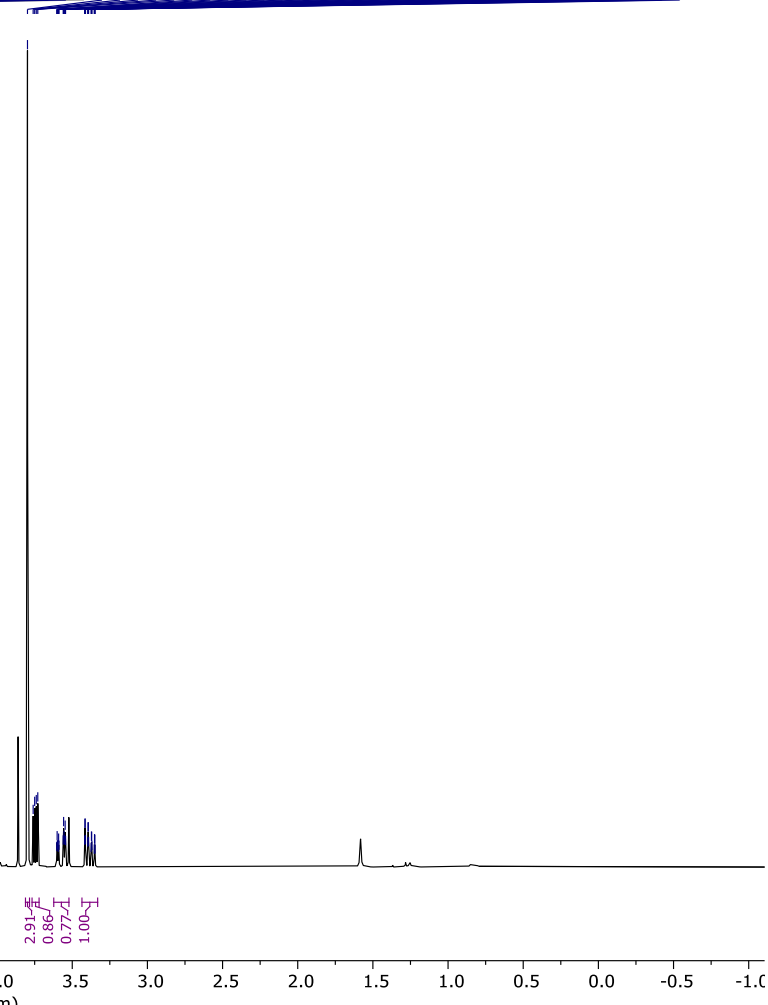


${ }^{13} \mathrm{C}$ NMR (101 MHz, $\mathrm{CDCl}_{3}$ ) of compound 8 :

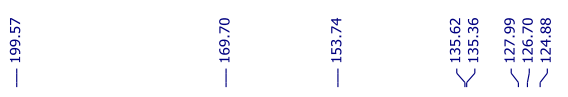

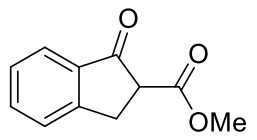

8
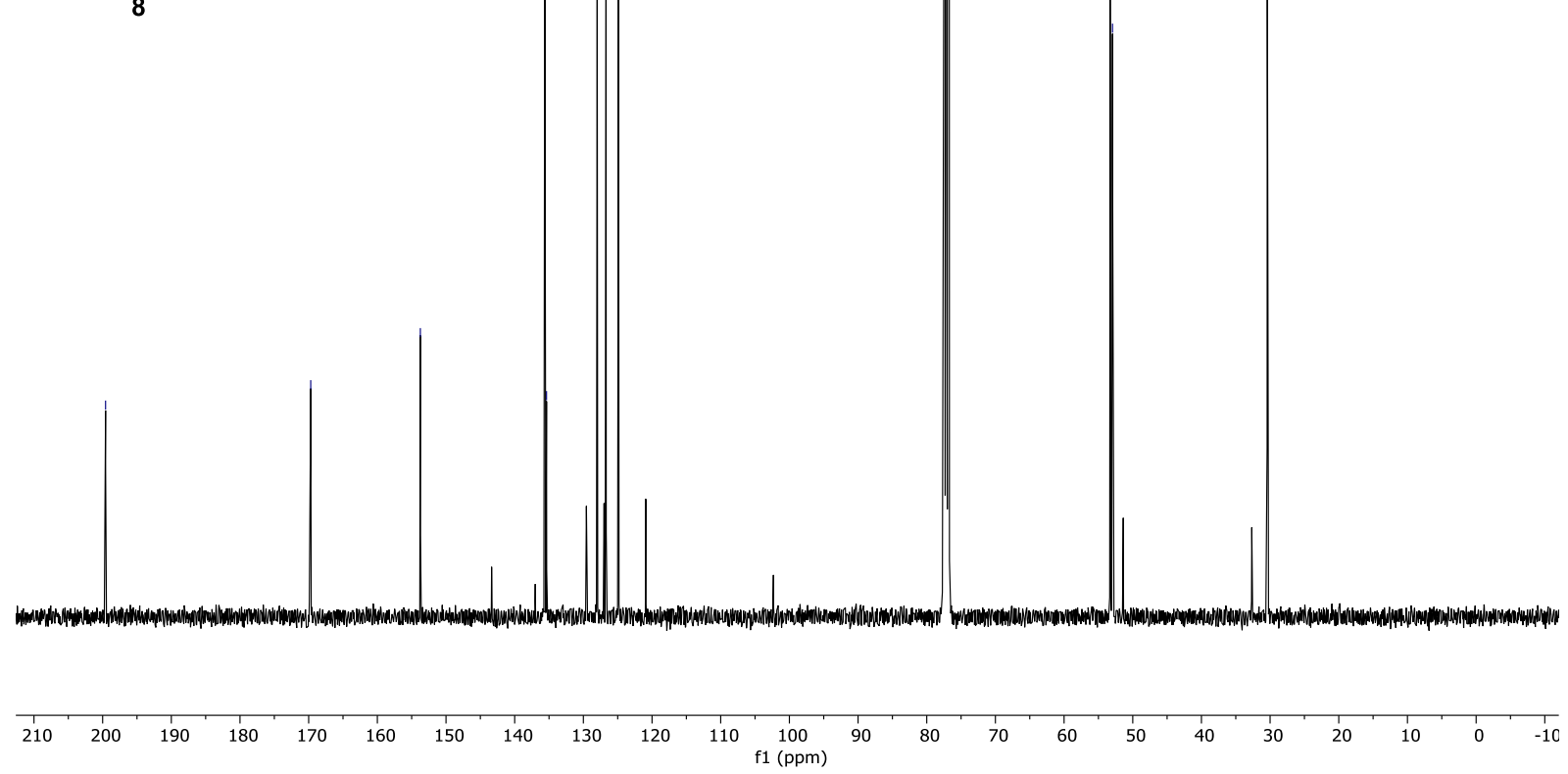

${ }^{1} \mathrm{H}$ NMR (400 MHz, $\mathrm{CDCl}_{3}$ ) of compound $\mathbf{9}$ :

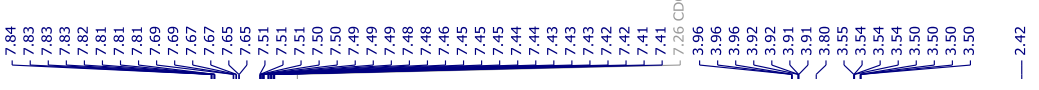
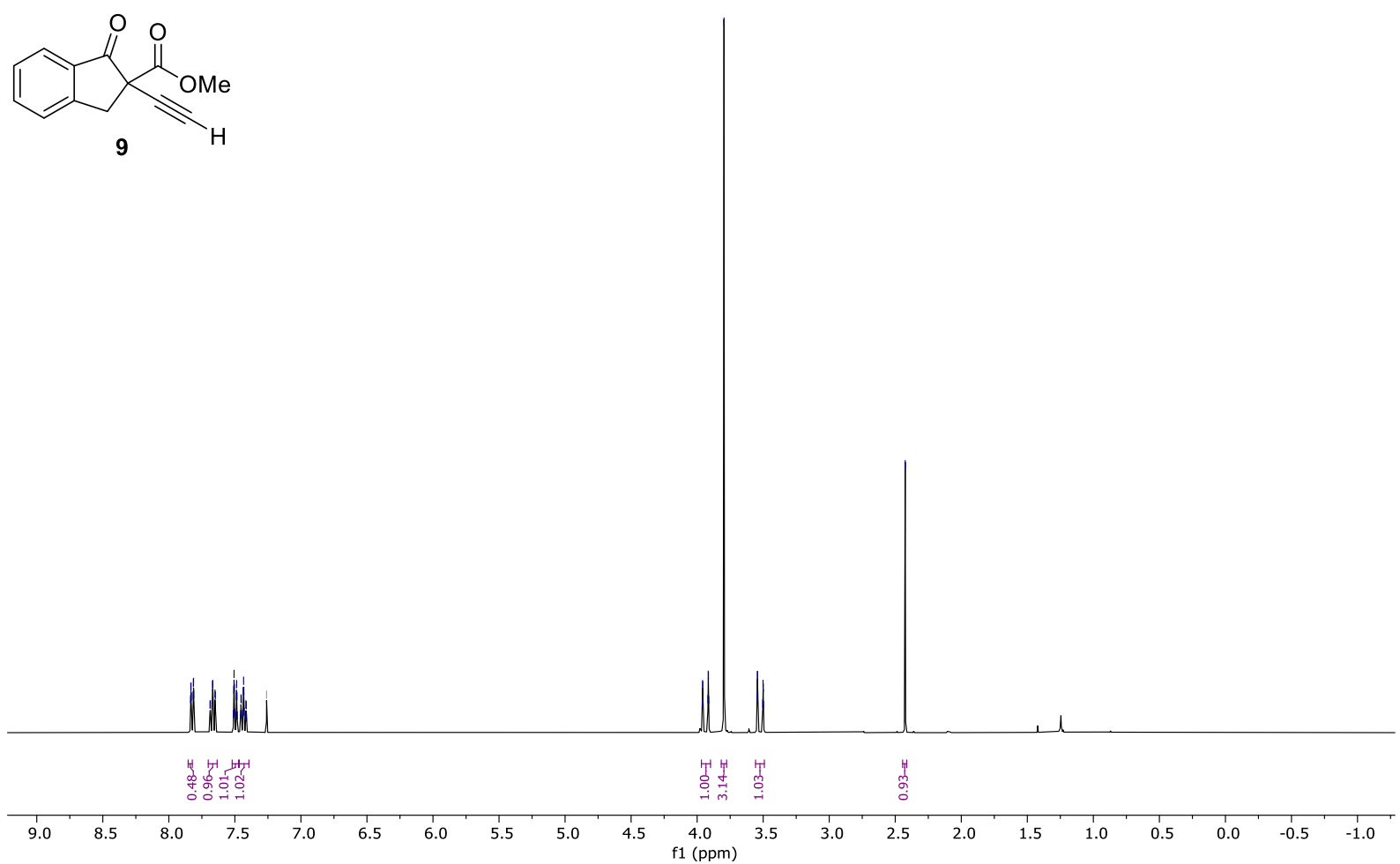
${ }^{13} \mathrm{C}$ NMR (101 MHz, $\mathrm{CDCl}_{3}$ ) of compound 9 :

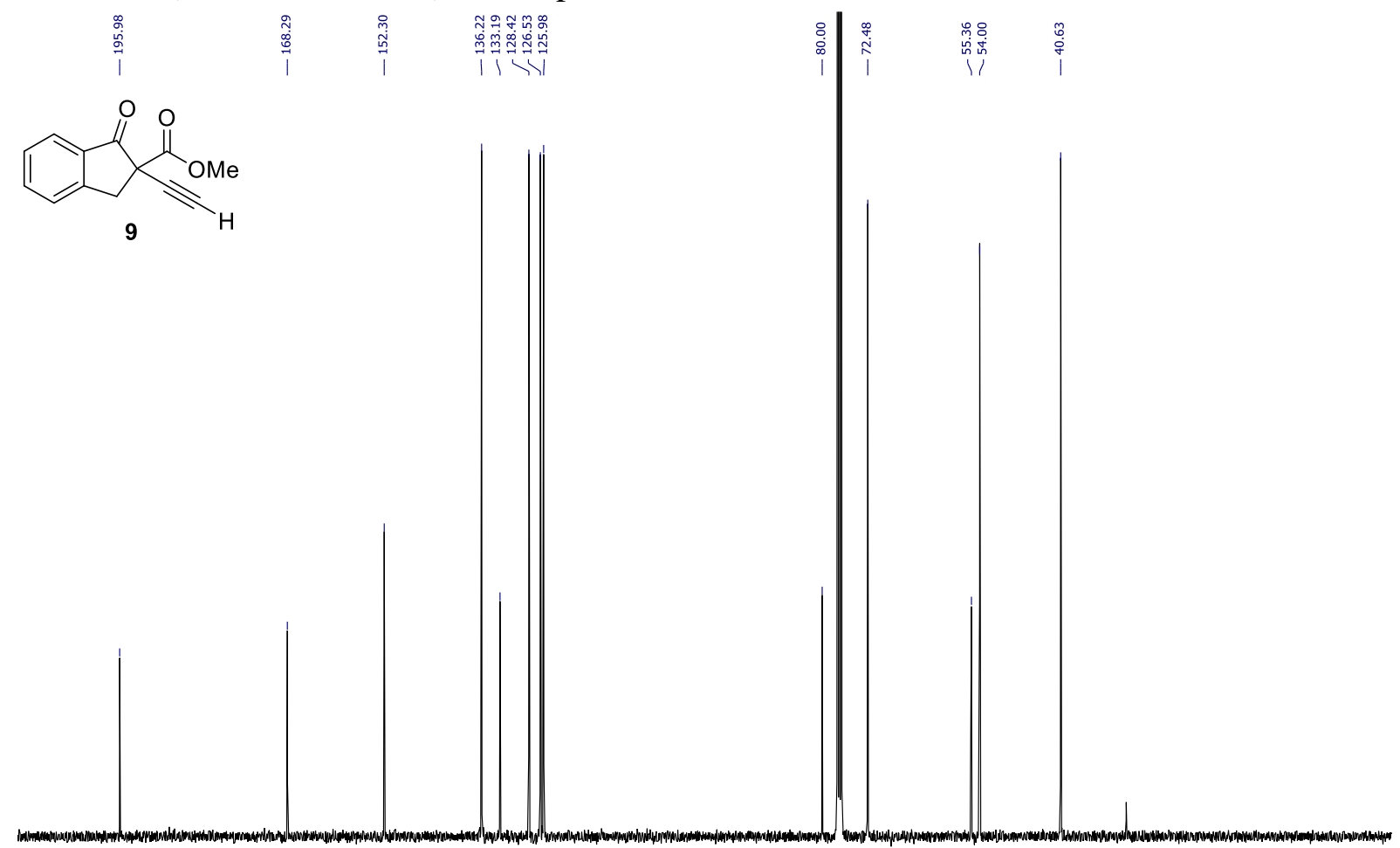

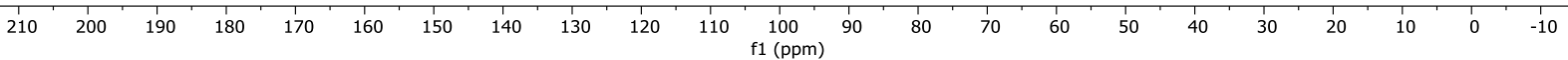

${ }^{1} \mathrm{H}$ NMR (400 MHz, $\mathrm{CDCl}_{3}$ ) of compound 11:

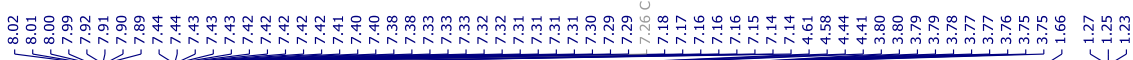<smiles>CCOC(C)(C#Cc1ccccc1)COC(=O)c1ccccc1I</smiles>

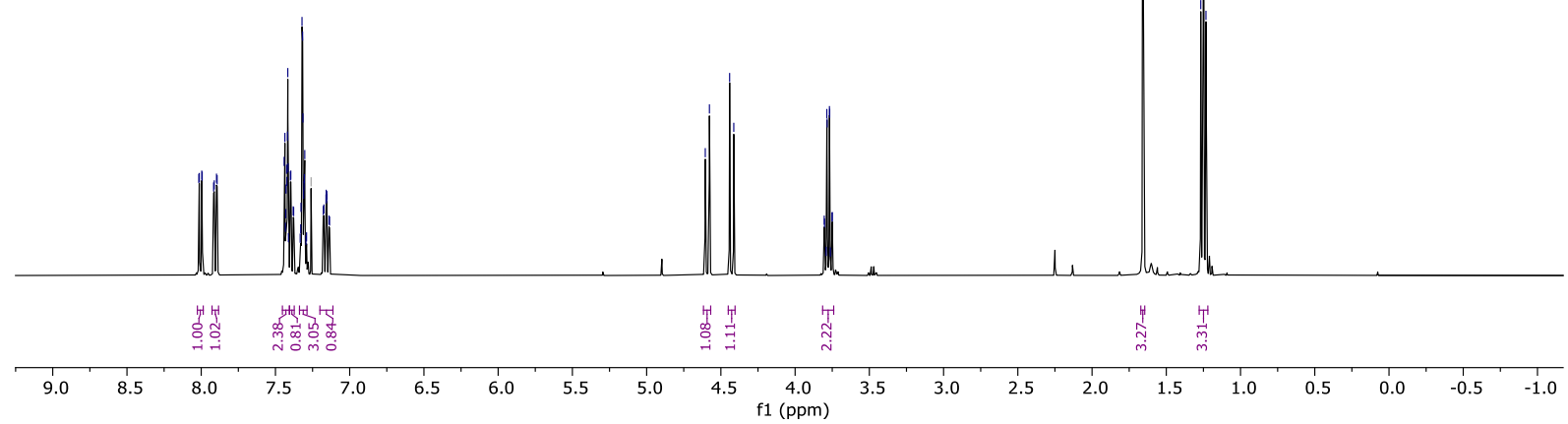


${ }^{13} \mathrm{C}$ NMR (101 MHz, $\mathrm{CDCl}_{3}$ ) of compound 11:
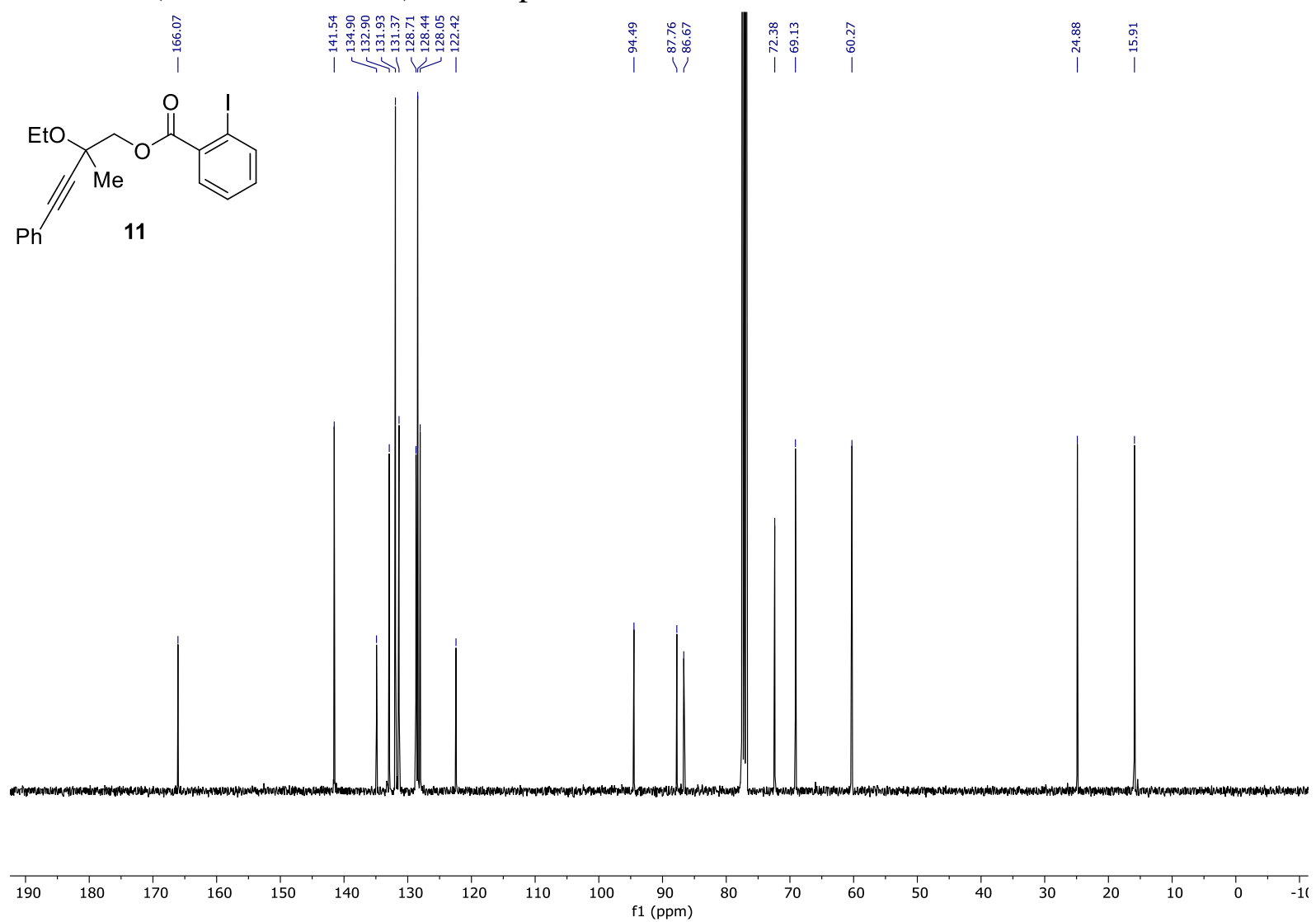

${ }^{1} \mathrm{H}$ NMR (400 MHz, $\mathrm{CDCl}_{3}$ ) of compound 13:
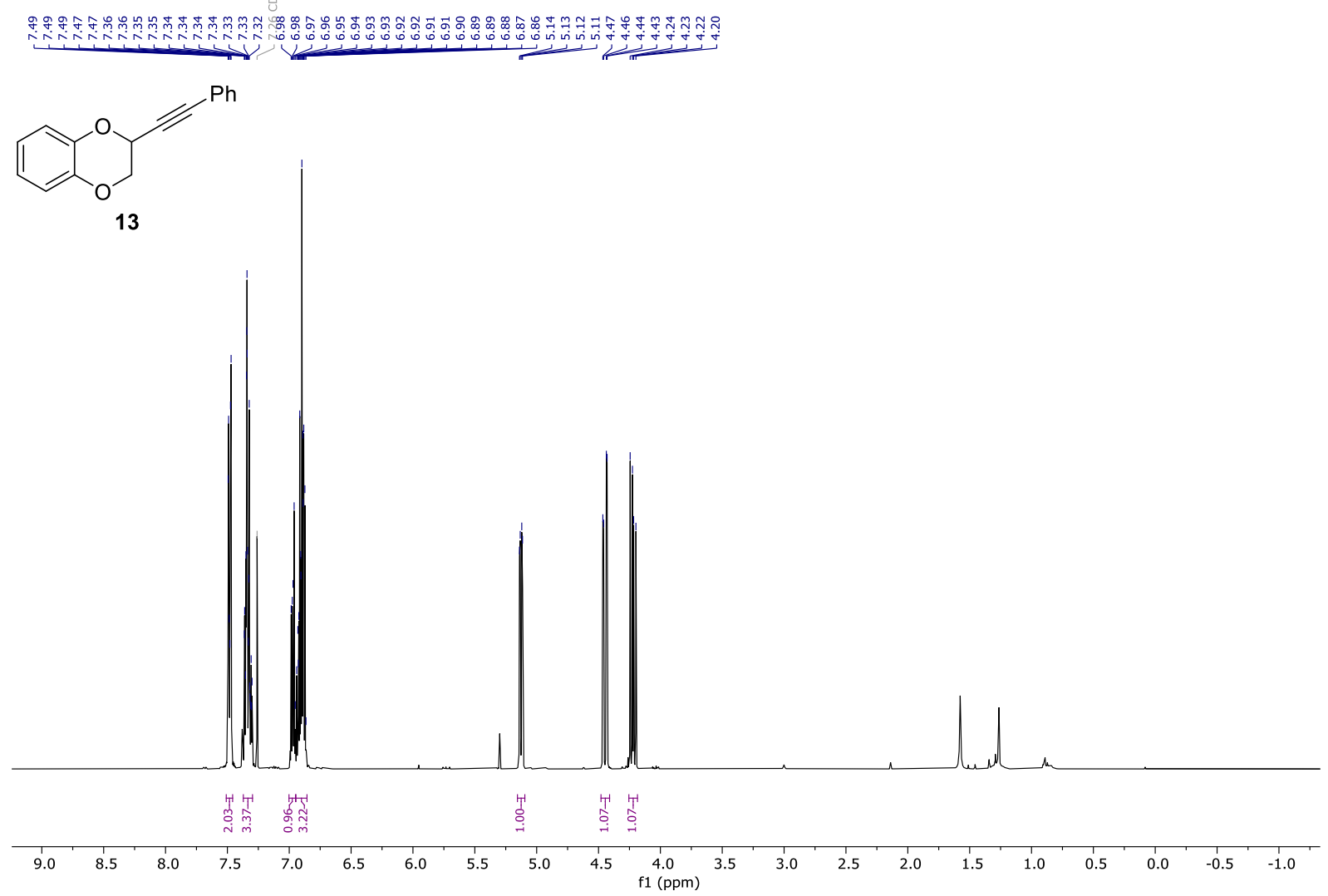

S80 
${ }^{13} \mathrm{C}$ NMR (101 MHz, $\left.\mathrm{CDCl}_{3}\right)$ of compound 13:

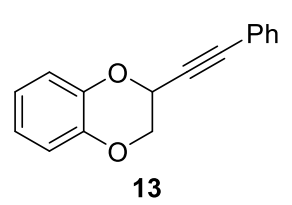

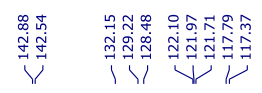
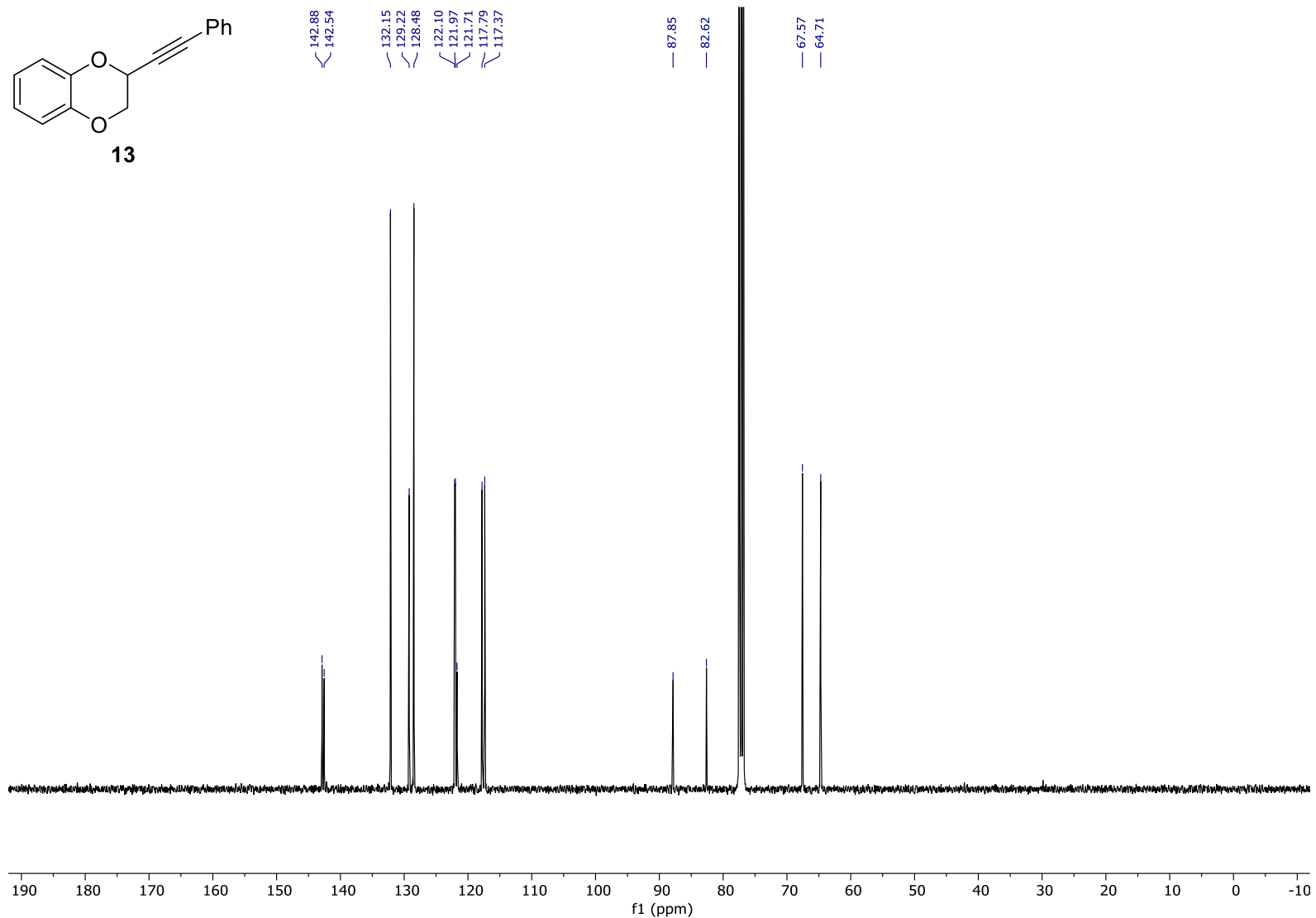

${ }^{1} \mathrm{H}$ NMR (400 MHz, $\mathrm{CDCl}_{3}$ ) of compound 15:

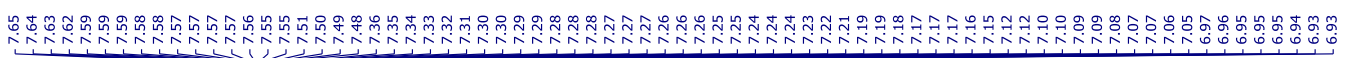
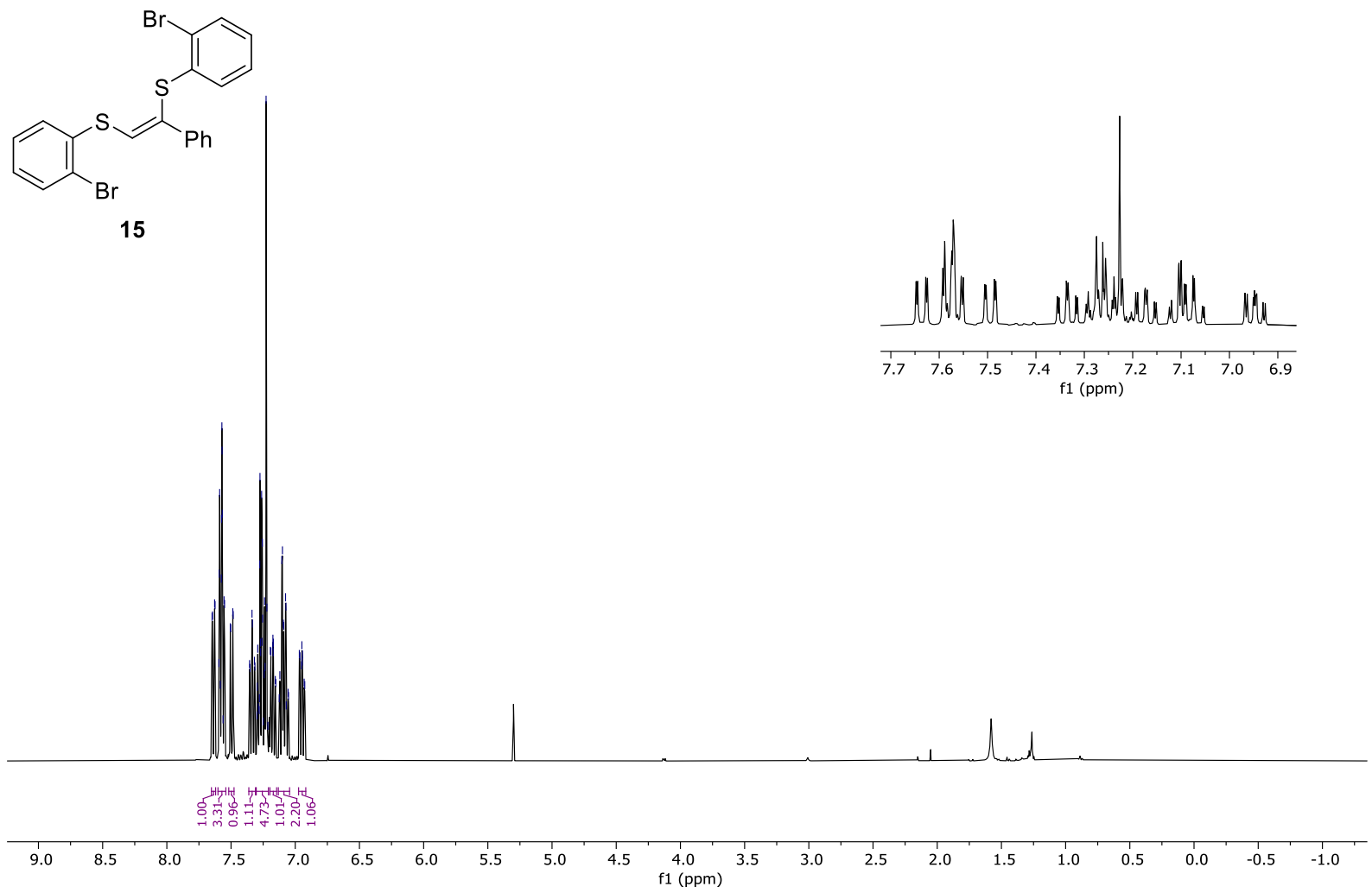

S81 
${ }^{13} \mathrm{C}$ NMR (101 MHz, $\mathrm{CDCl}_{3}$ ) of compound 15:
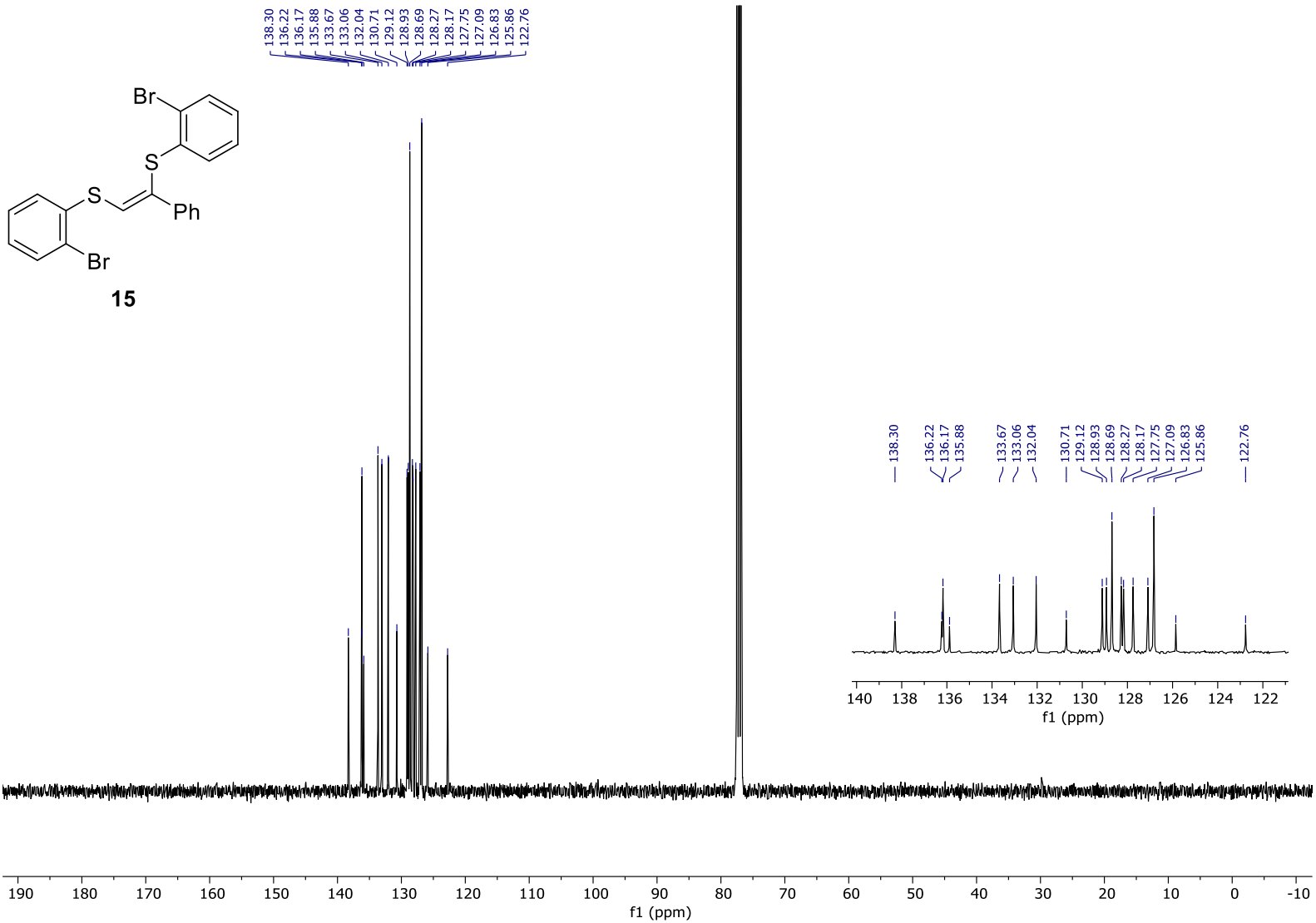

${ }^{1} \mathrm{H}$ NMR (400 MHz, acetone- $\mathrm{d}_{6}$ ) of compound $\mathbf{1 7}$ :
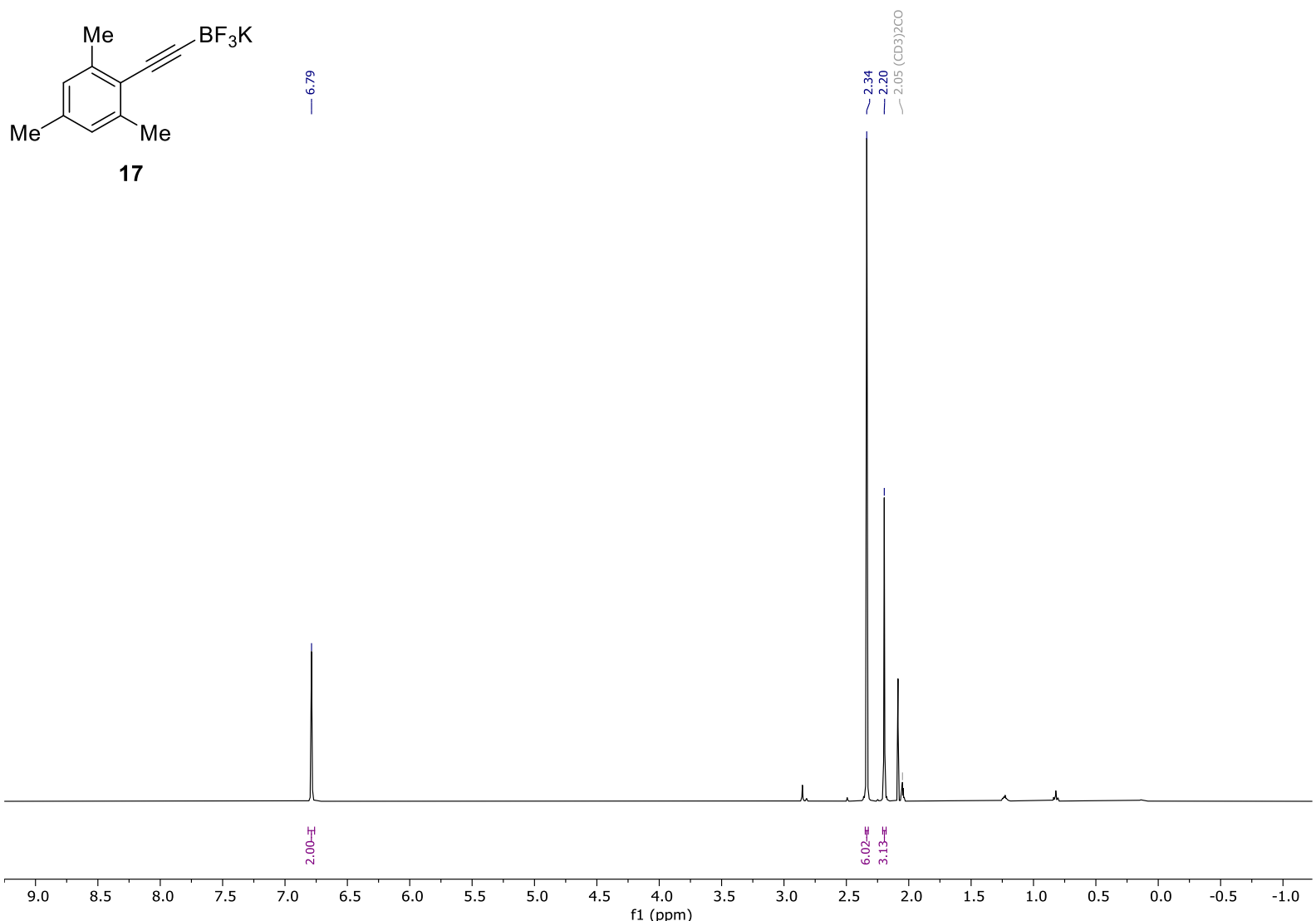
${ }^{13} \mathrm{C}$ NMR (101 MHz, acetone-d $\left.\mathrm{d}_{6}\right)$ of compound 17:
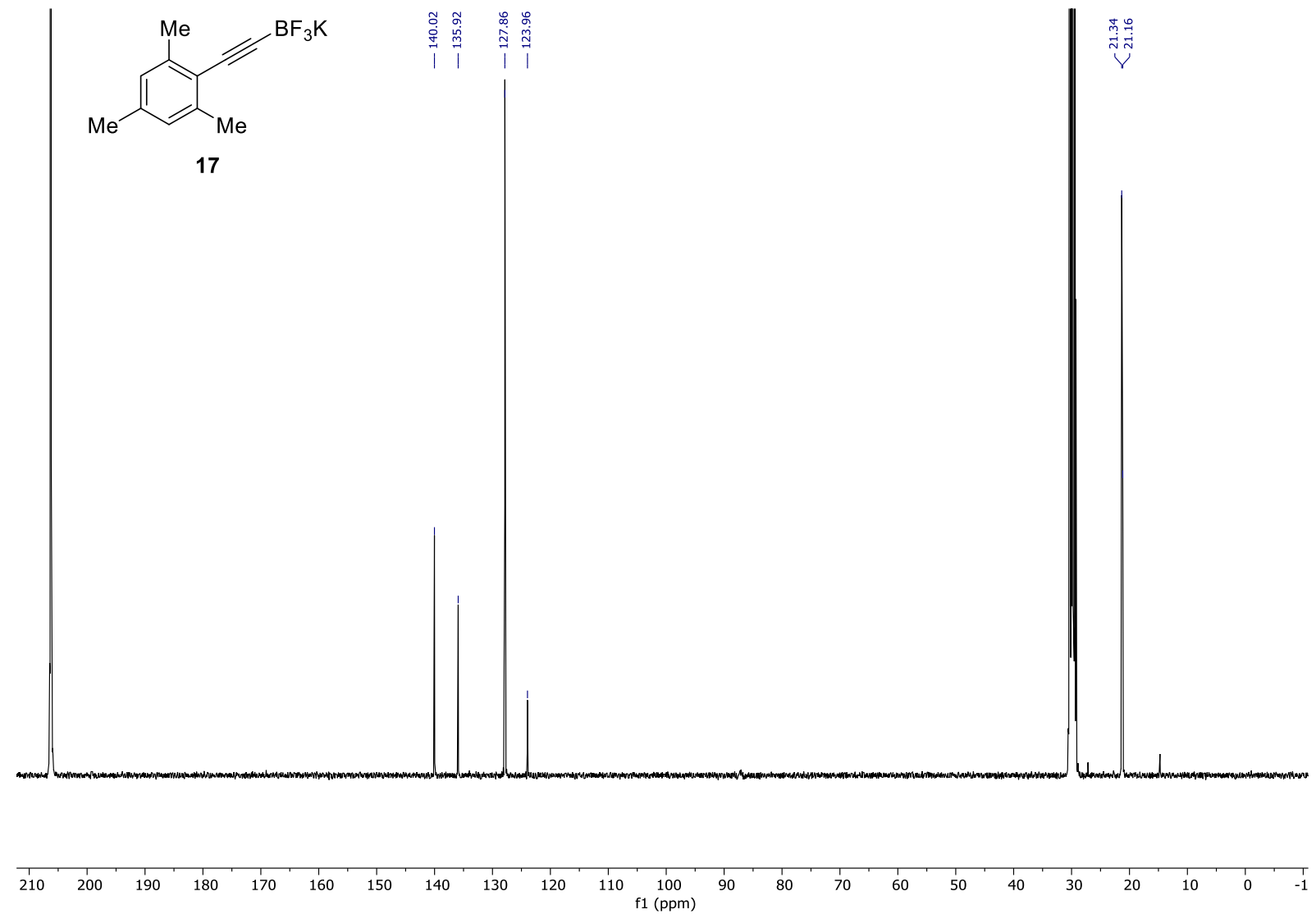

${ }^{19} \mathrm{~F}$ NMR (377 MHz, acetone- $\mathrm{d}_{6}$ ) of compound 17:

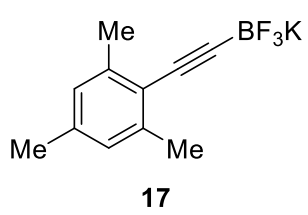

\begin{tabular}{lllllllllllllllllllllllll}
\hline & 10 & 0 & -10 & -20 & -30 & -40 & -50 & -60 & -70 & -80 & -90 & -100 & -110 & -120 & -130 & -140 & -150 & -160 & -170 & -180 & -190 & -200 & -210 & -2
\end{tabular} 
${ }^{11}$ B NMR (128 MHz, acetone- $\left.\mathrm{d}_{6}\right)$ of compound 17:

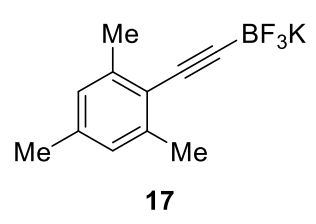

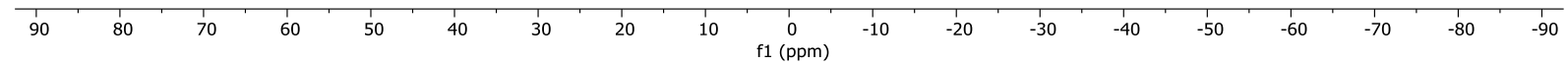

${ }^{1} \mathrm{H}$ NMR (400 MHz, acetone- $\mathrm{d}_{6}$ ) of compound 18:
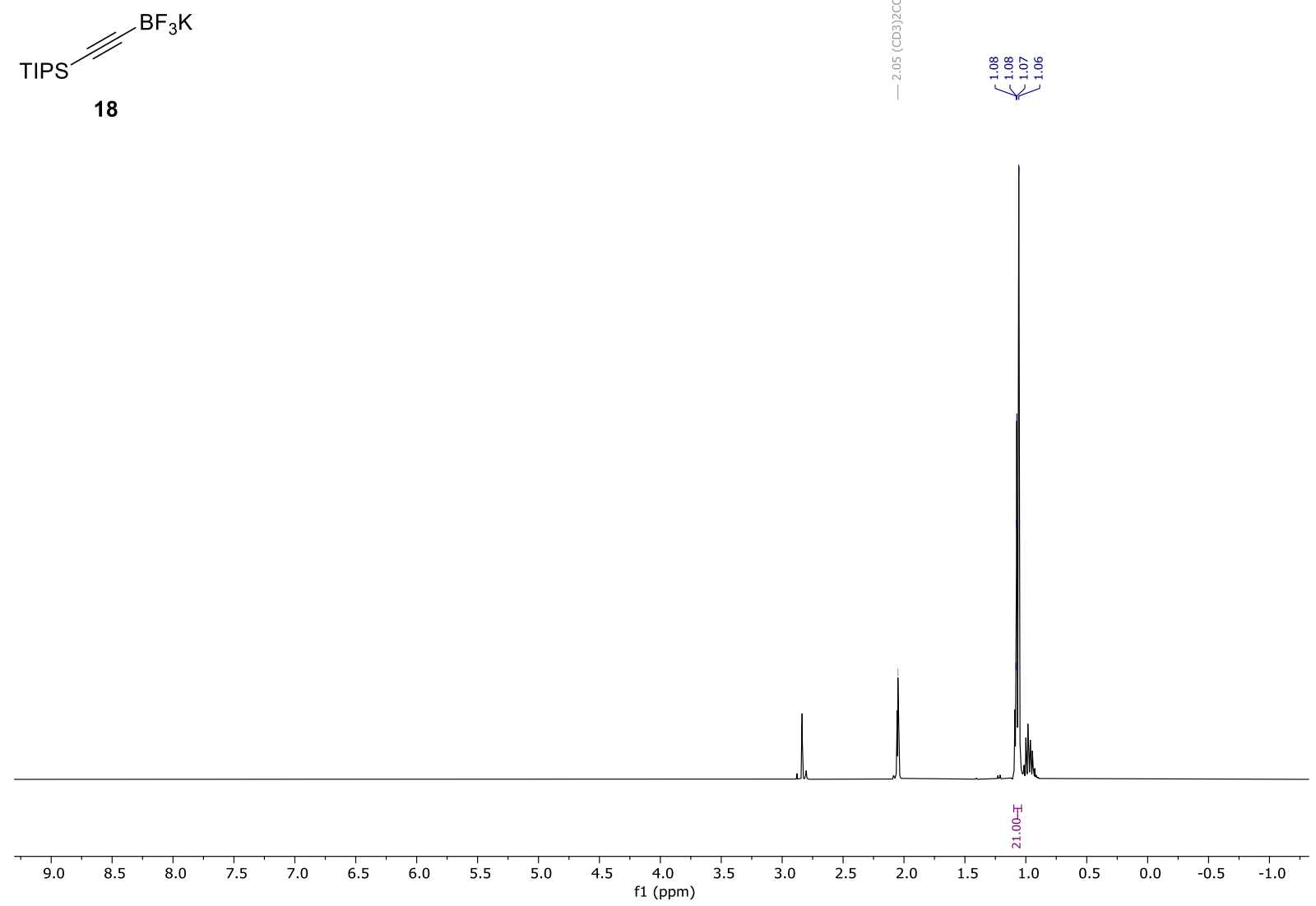
${ }^{13} \mathrm{C}$ NMR (101 MHz, acetone- $\mathrm{d}_{6}$ ) of compound $\mathbf{1 8}$ :

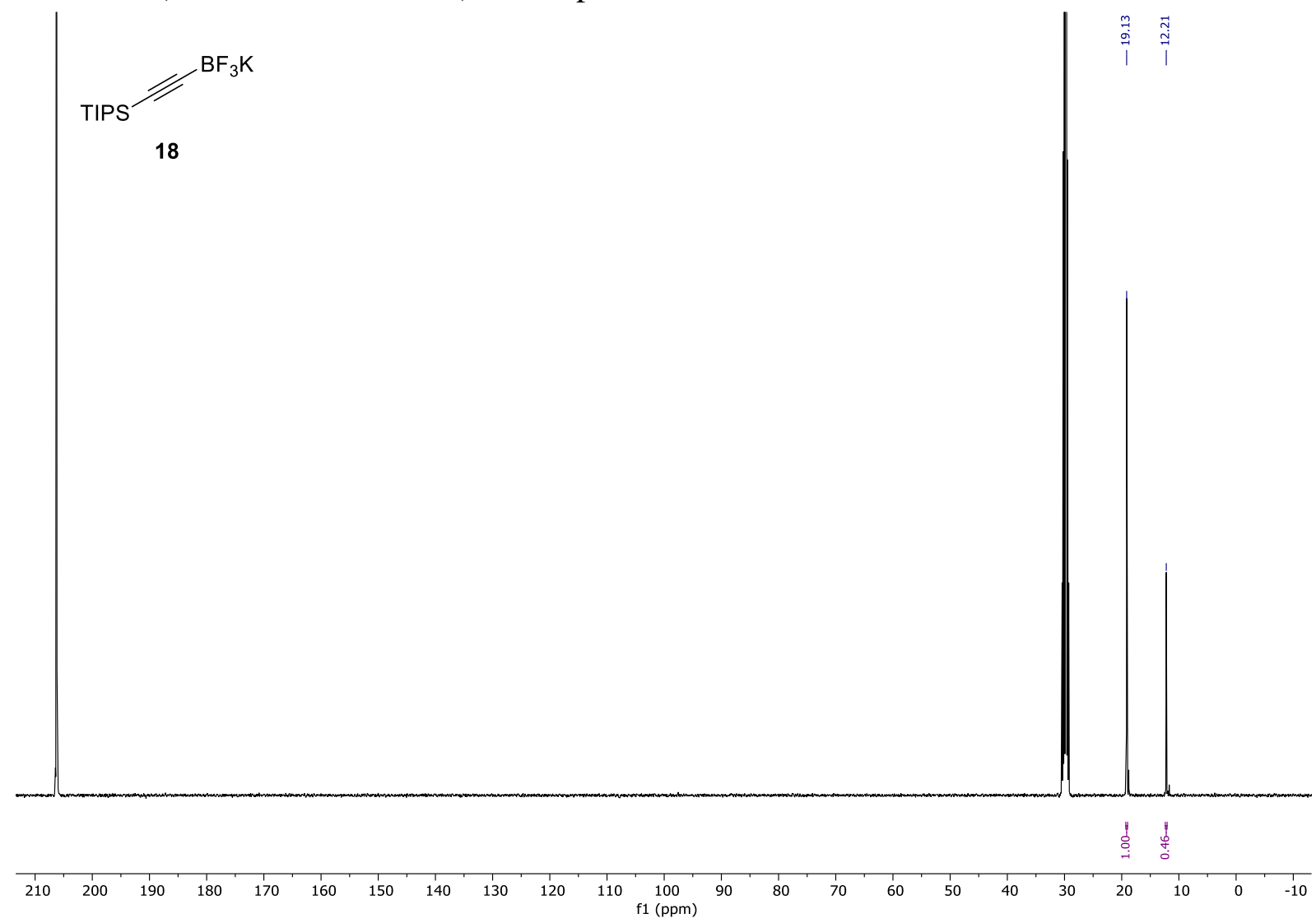

${ }^{19} \mathrm{~F}$ NMR (377 MHz, acetone-d 6 ) of compound $\mathbf{1 8}$ :
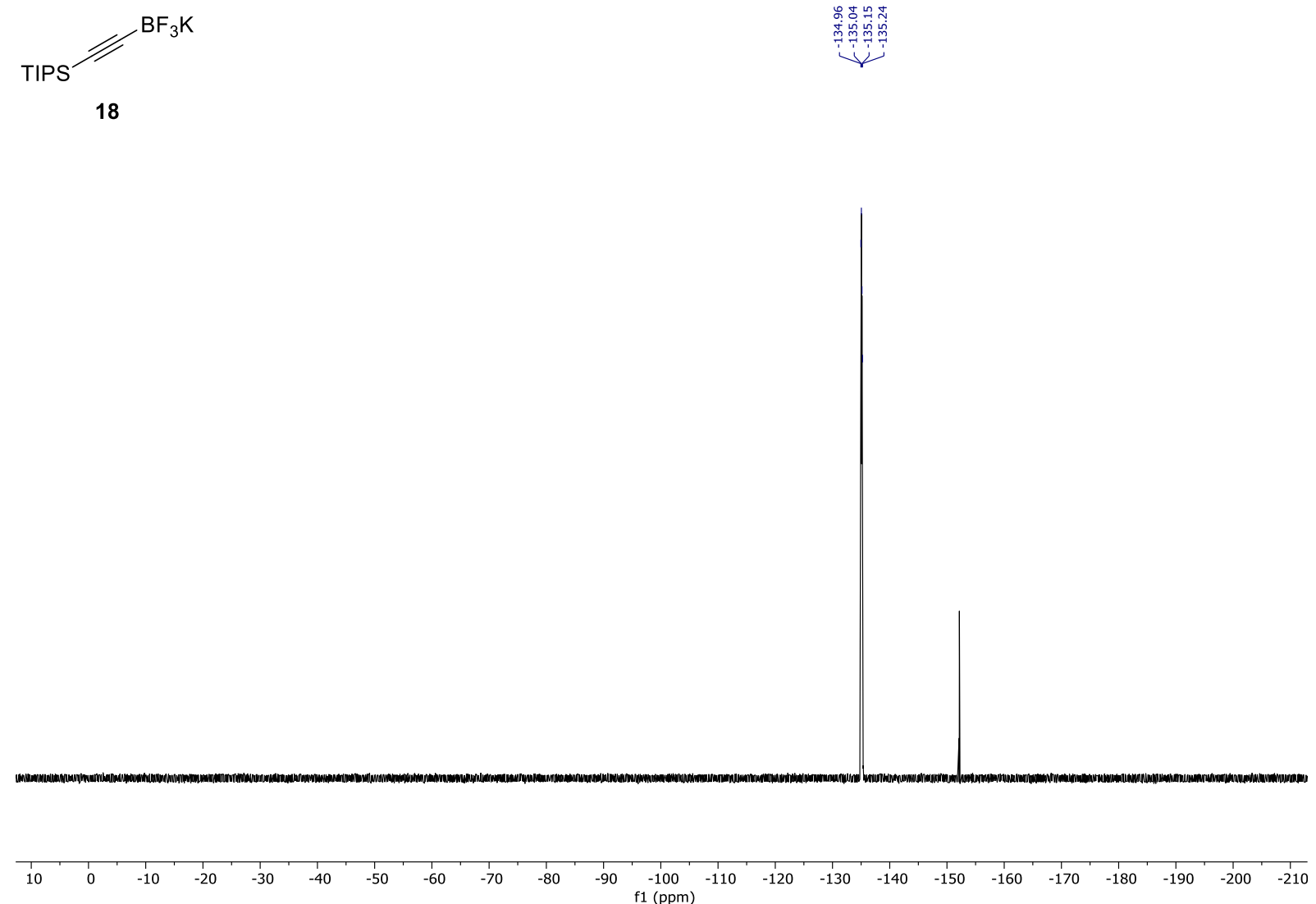
${ }^{1} \mathrm{H}$ NMR (400 MHz, DMSO-d 6 ) of compound 19:

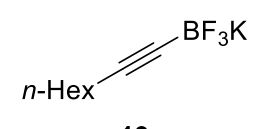

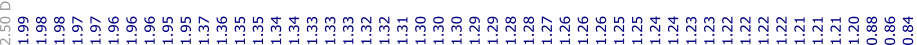

19
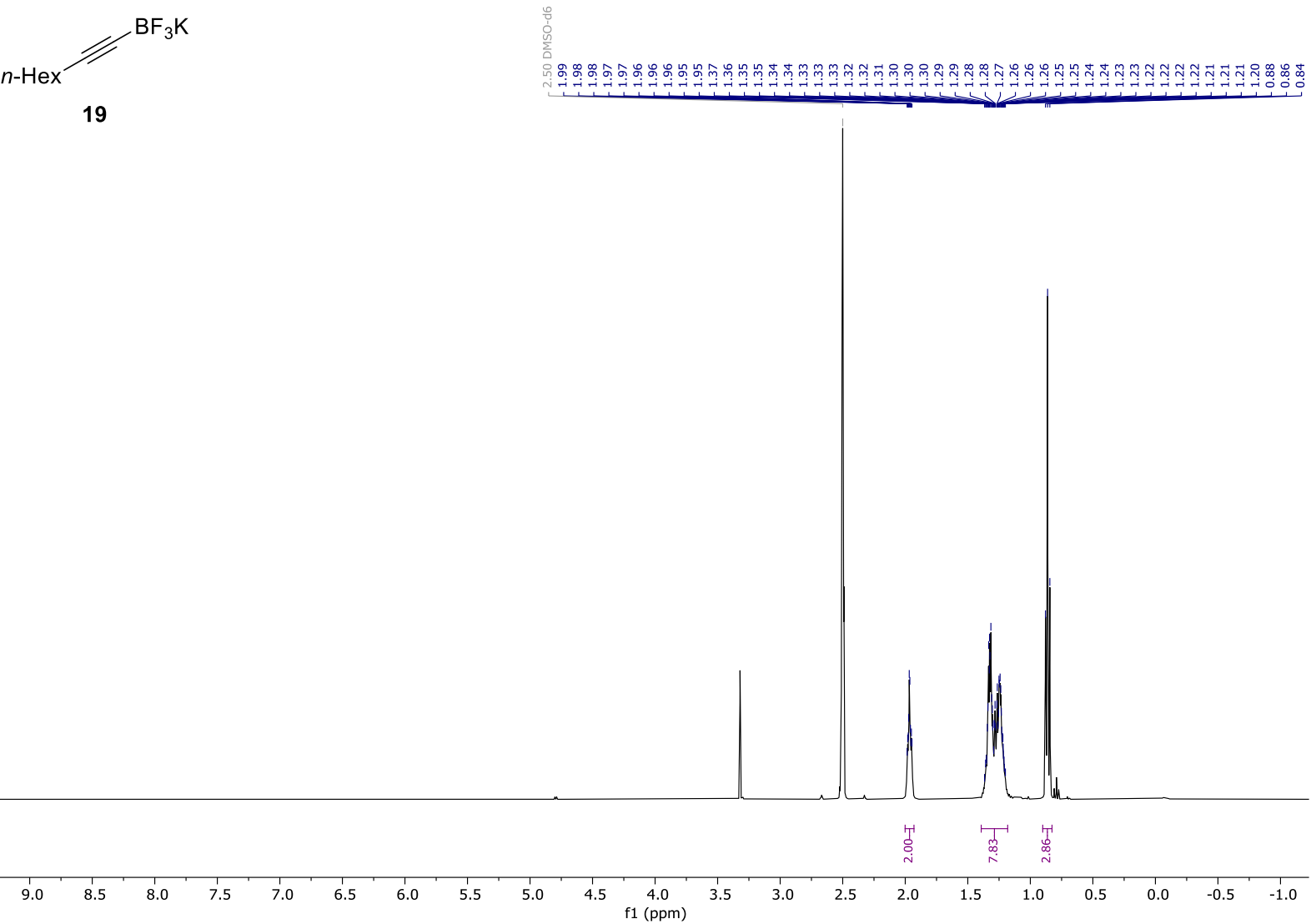

${ }^{13} \mathrm{C}$ NMR (101 MHz, DMSO-d 6 ) of compound 19:
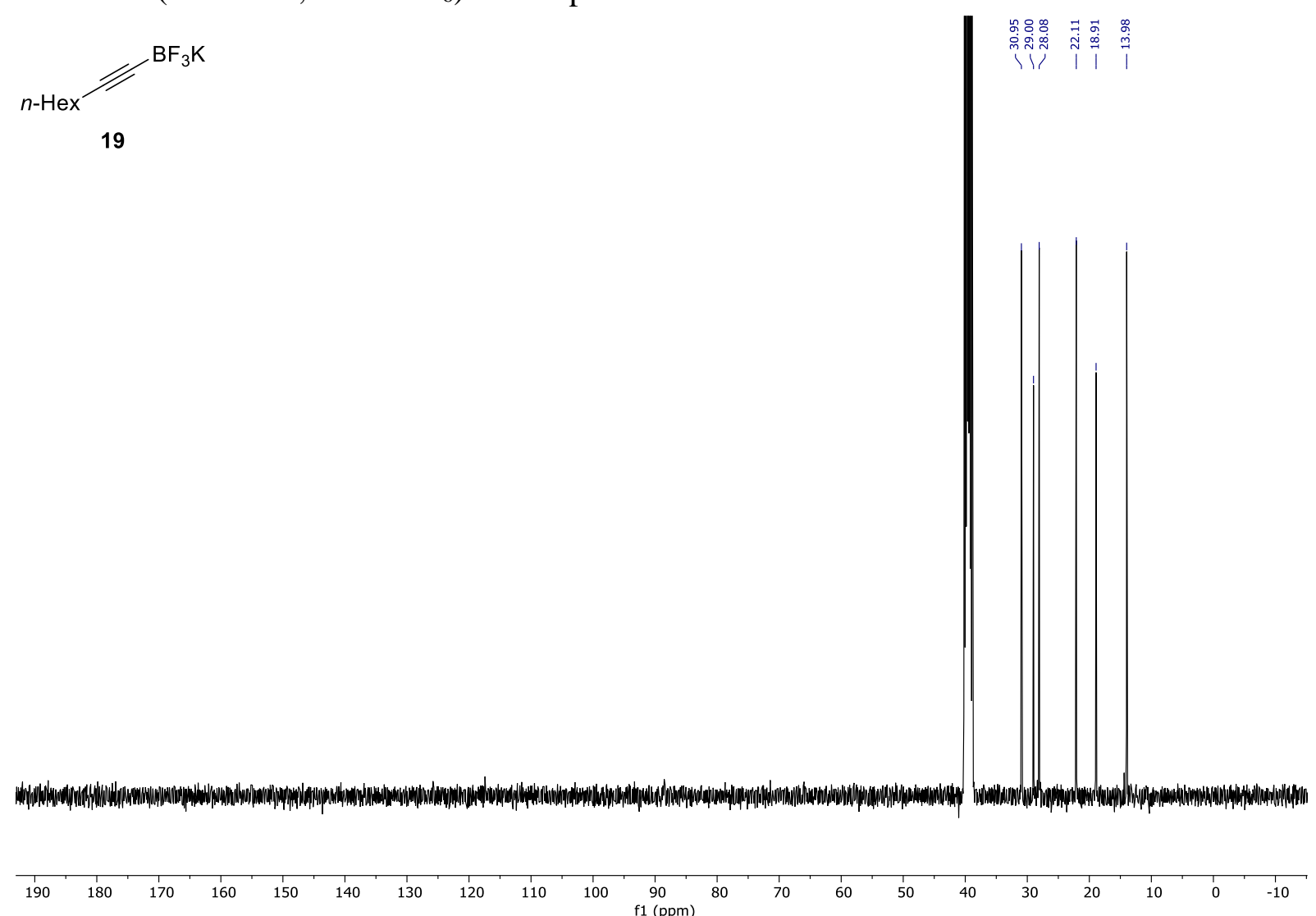
${ }^{19}$ F NMR (377 MHz, DMSO-d $\mathrm{d}_{6}$ ) of compound 19:

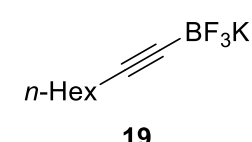

19

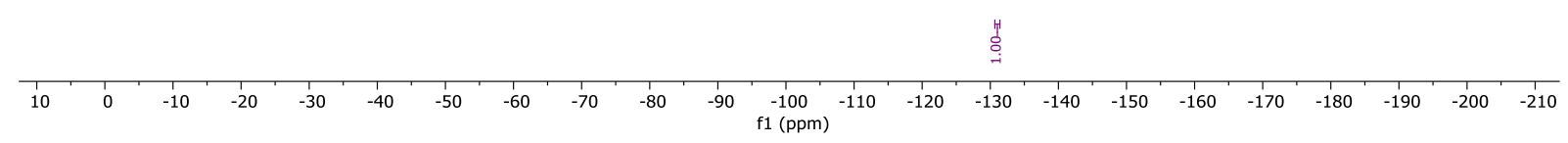

${ }^{1} \mathrm{H}$ NMR (400 MHz, acetone- $\mathrm{d}_{6}$ ) of compound 21:

$\mathrm{Me}=\frac{\overline{2}}{21} \mathrm{BF}_{3} \mathrm{~K}$
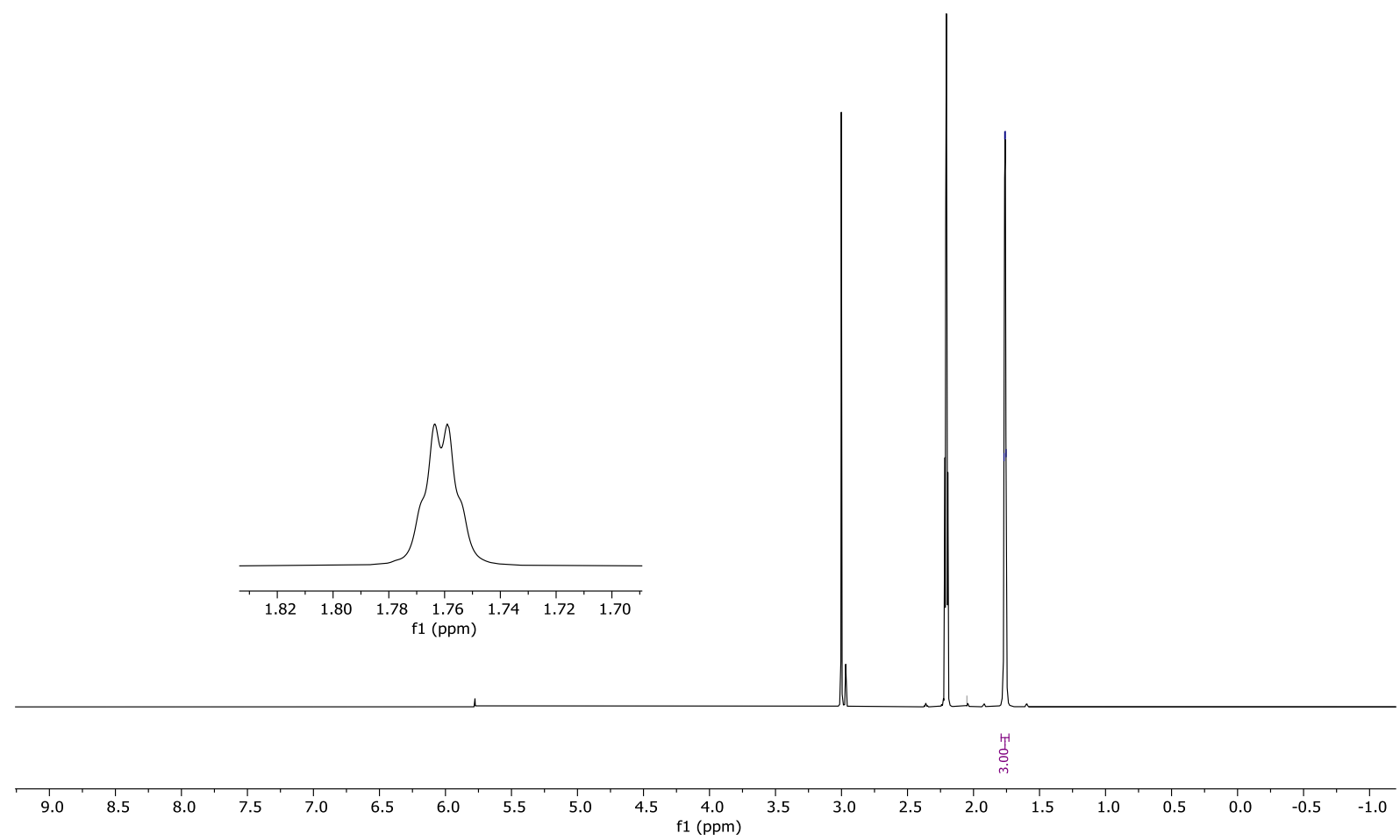
${ }^{13} \mathrm{C}$ NMR (101 MHz, acetone- $\left.\mathrm{d}_{6}\right)$ of compound 21:

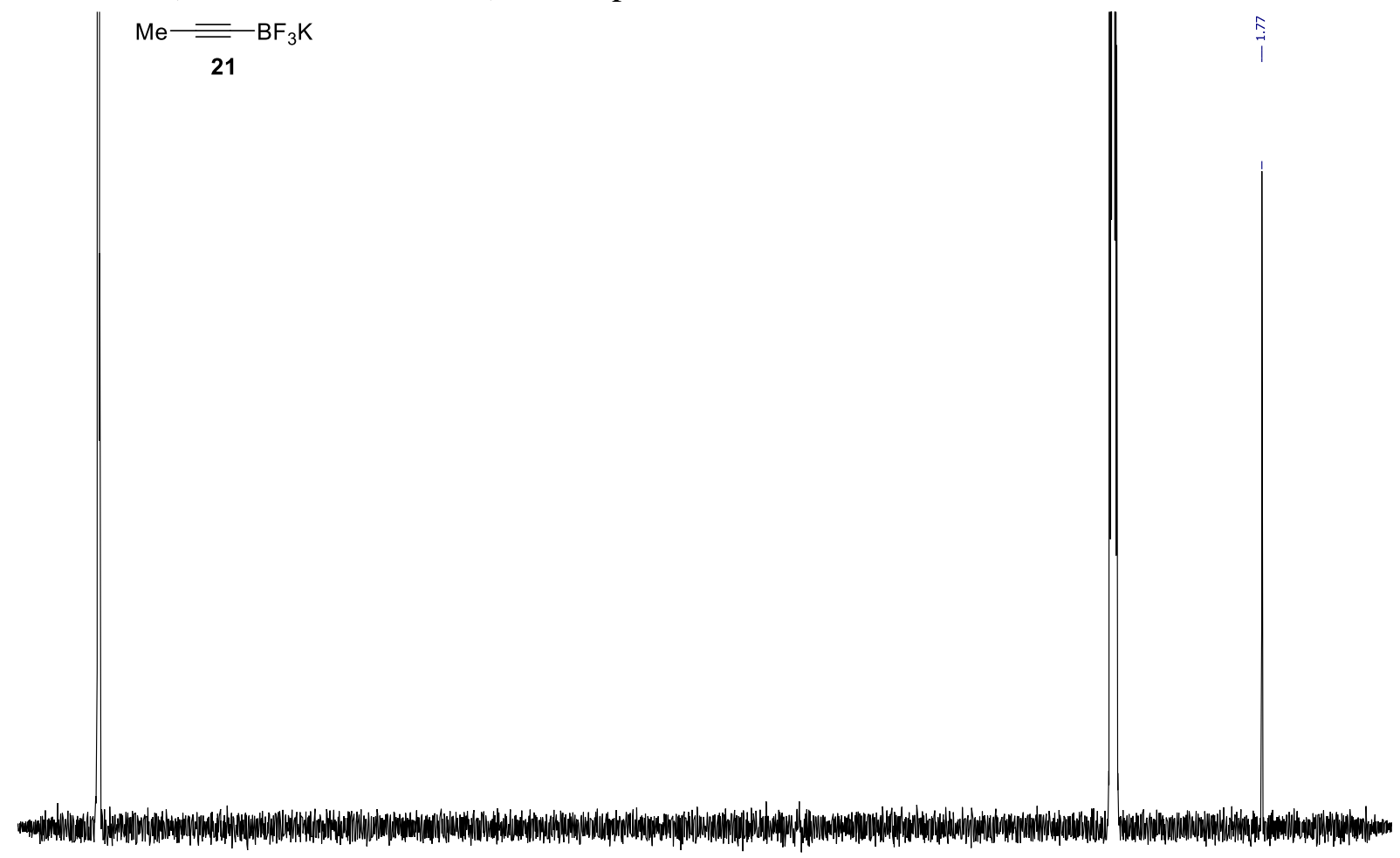

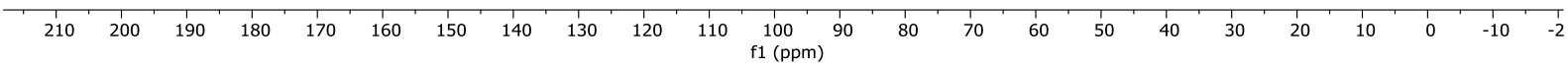

${ }^{19}$ F NMR (376 MHz, acetone- $\mathrm{d}_{6}$ ) of compound 21:

$\mathrm{Me}=\mathrm{BF}_{3} \mathrm{~K}$

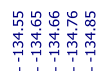

21

舟

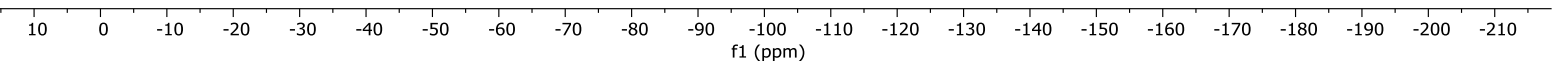


${ }^{11}$ B NMR (128 MHz, acetone- $\mathrm{d}_{6}$ ) of compound 21:
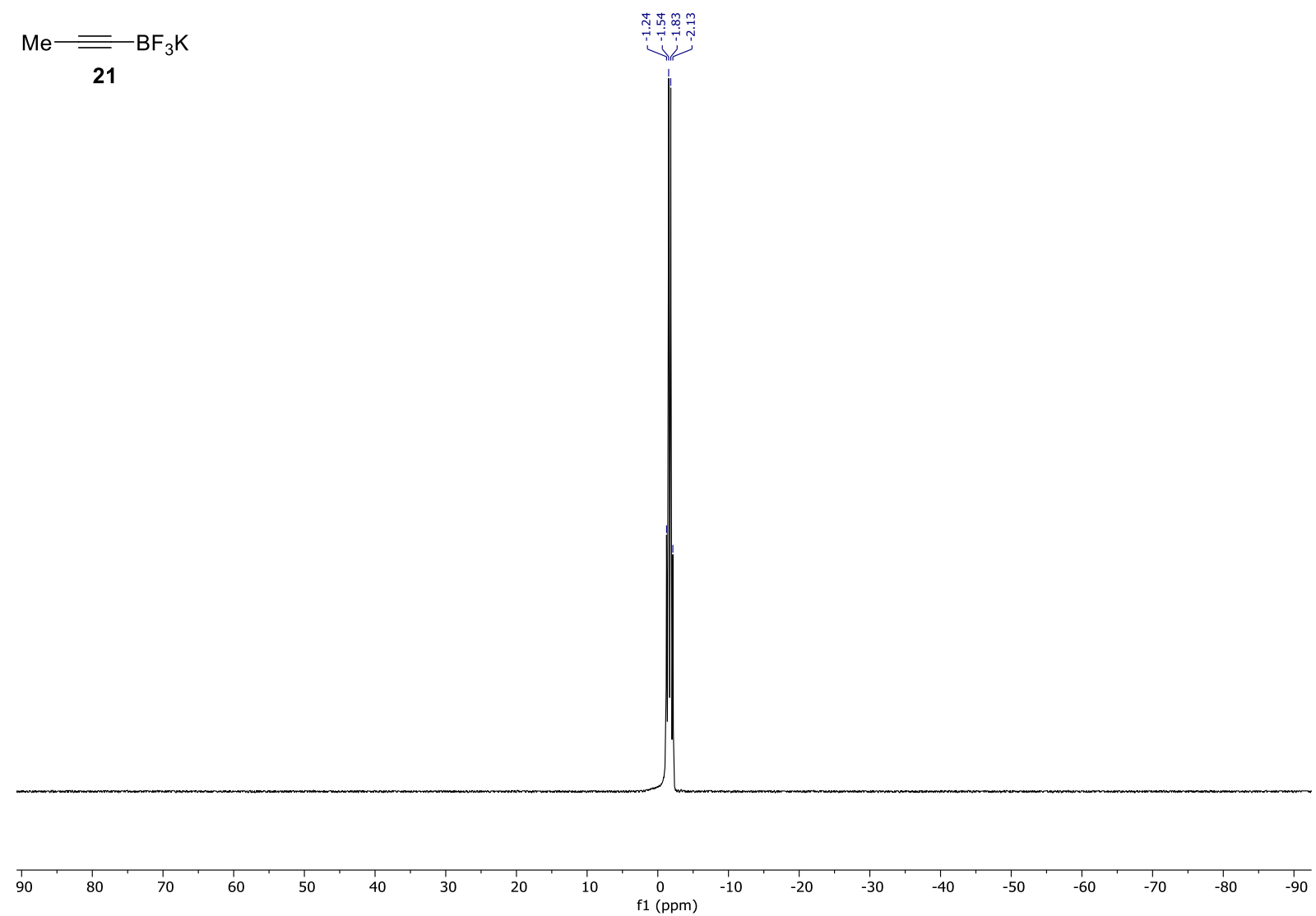

HRMS (ESI/QTOF, negative mode) of compound 21:

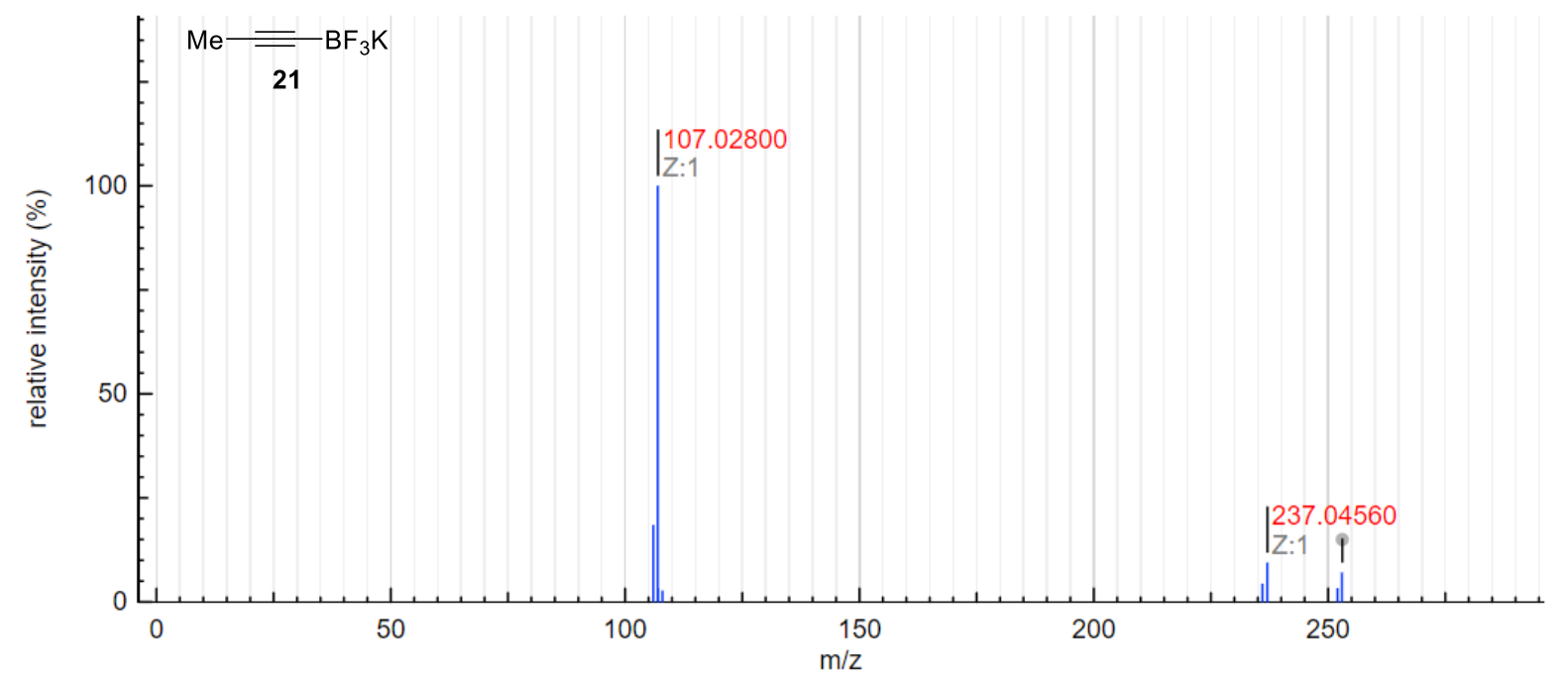


${ }^{1} \mathrm{H}$ NMR (400 MHz, acetone- $\mathrm{d}_{6}$ ) of compound 22:
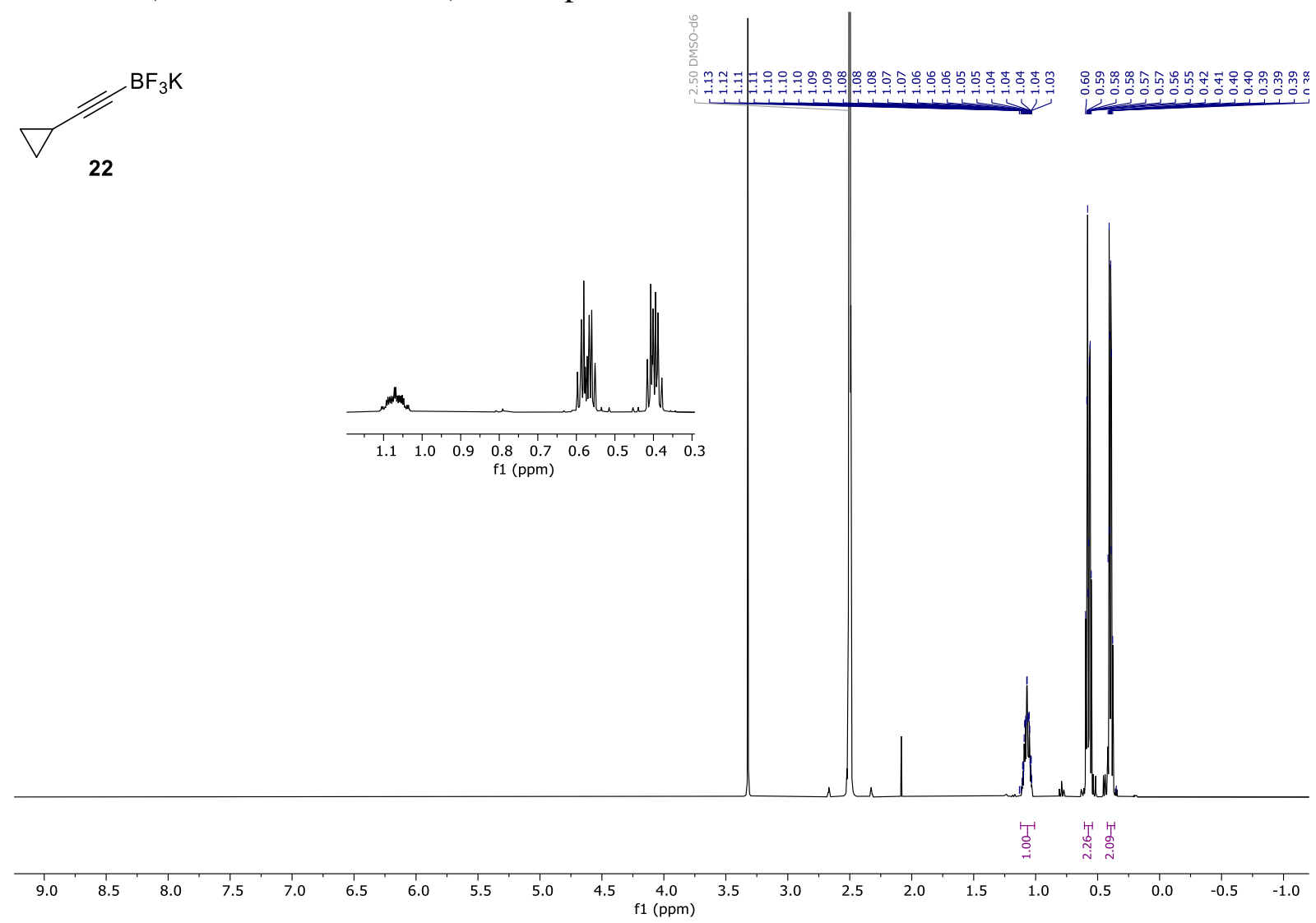

${ }^{13} \mathrm{C}$ NMR (101 MHz, acetone- $\mathrm{d}_{6}$ ) of compound 22:

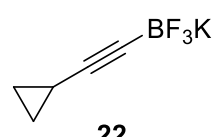

22 
${ }^{19}$ F NMR (376 MHz, acetone- $\mathrm{d}_{6}$ ) of compound 22:
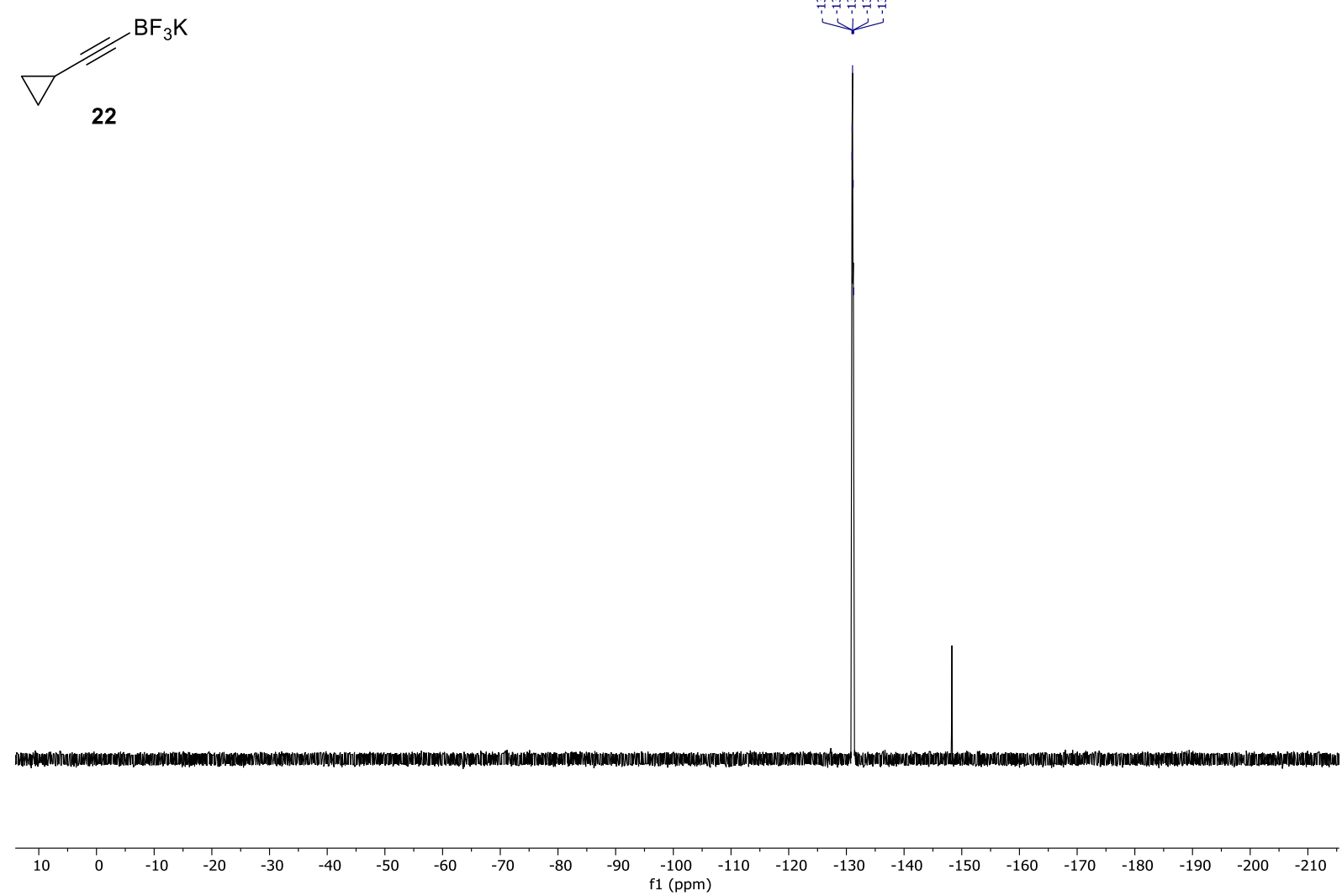

${ }^{11}$ B NMR (128 MHz, acetone- $\mathrm{d}_{6}$ ) of compound 22:

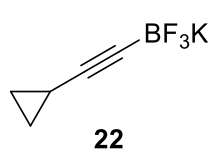

위부ำ웍워

(1)

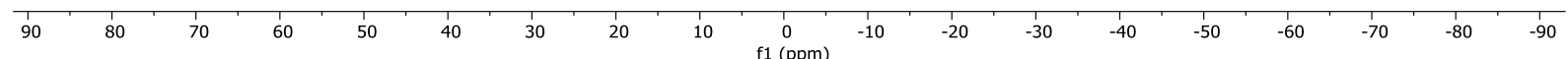


HRMS (ESI/QTOF, negative mode) of compound 22:

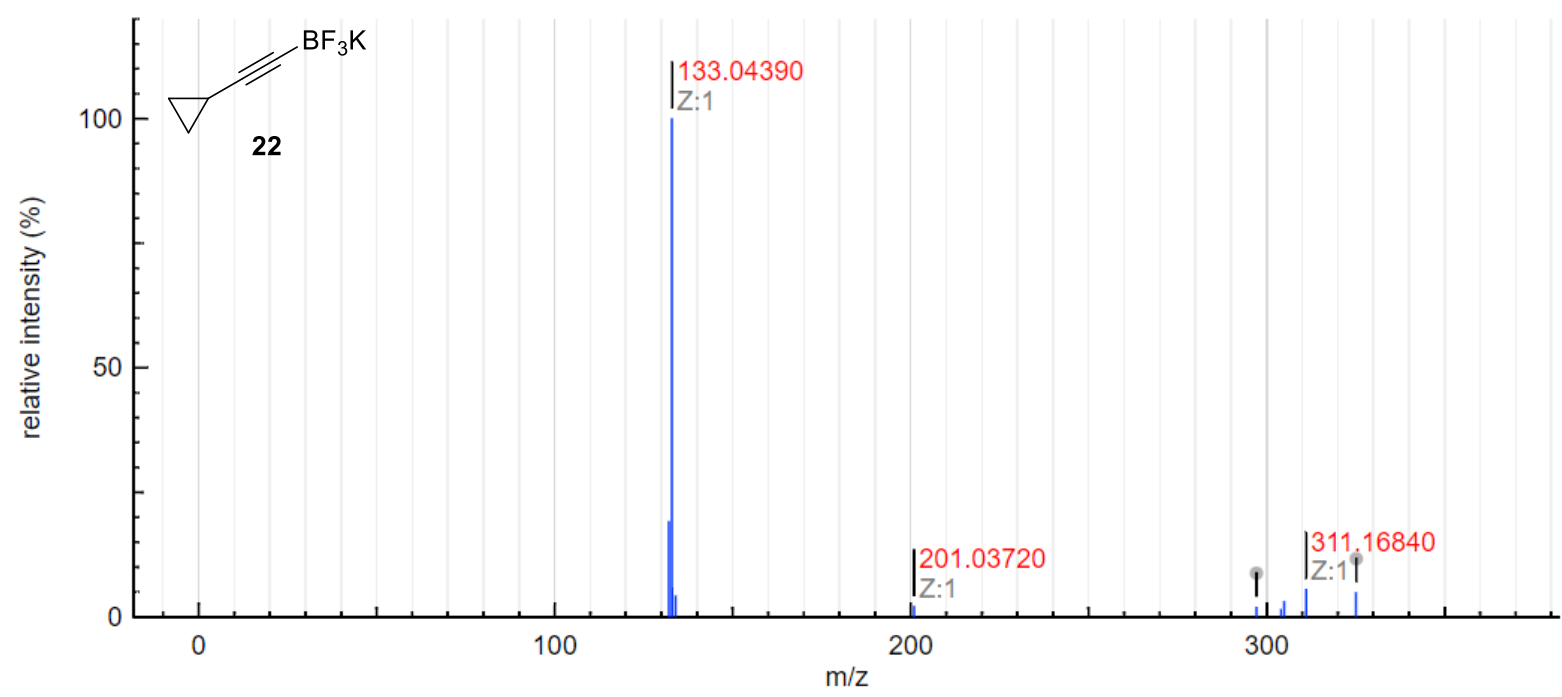

${ }^{1} \mathrm{H}$ NMR (400 MHz, DMSO-d 6 ) of compound 24:

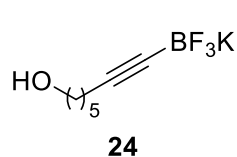

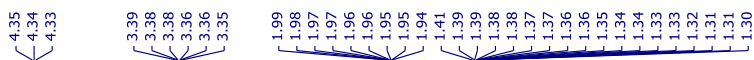

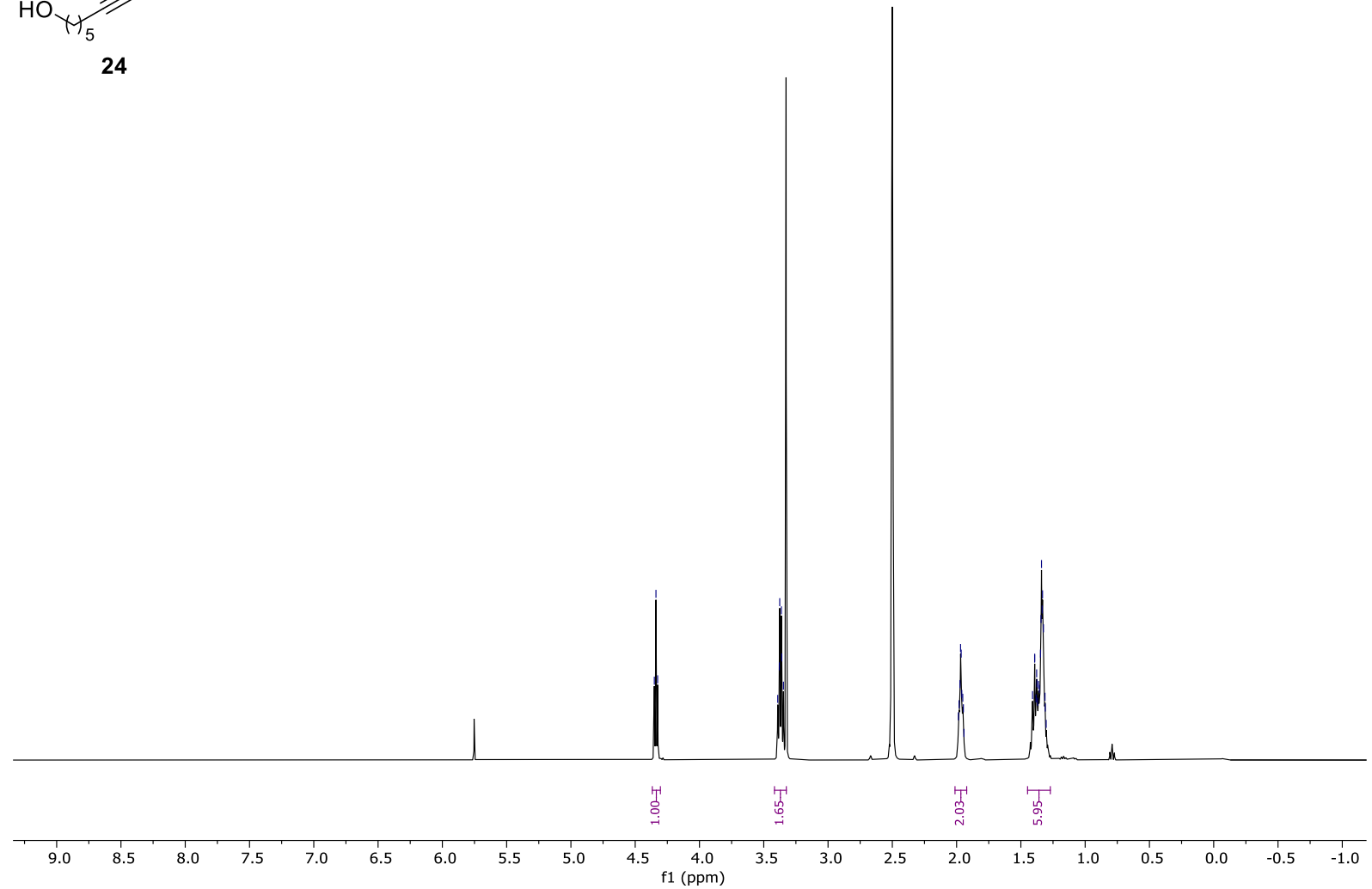


${ }^{13} \mathrm{C}$ NMR (101 MHz, DMSO-d 6 ) of compound 24:<smiles>[13CH3]C#CO</smiles>

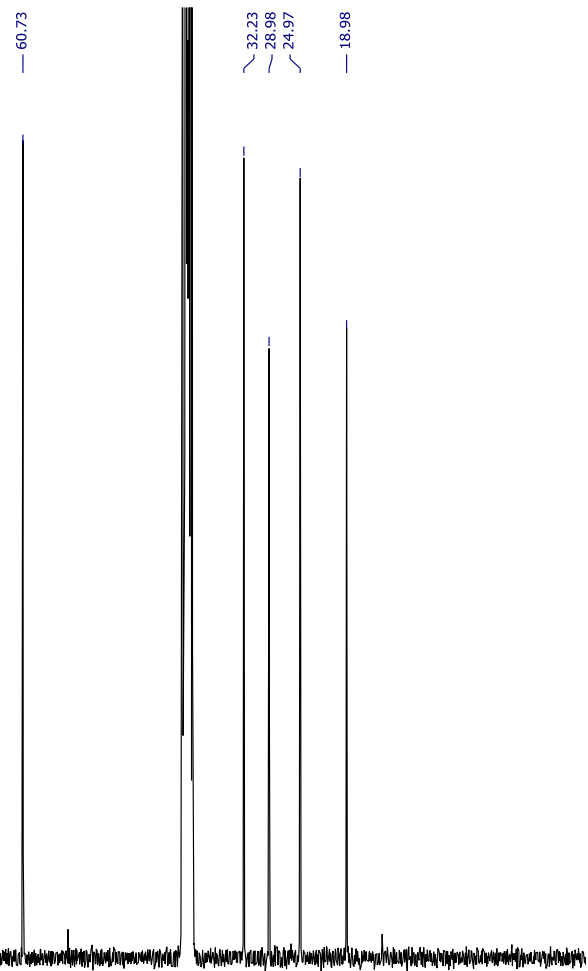

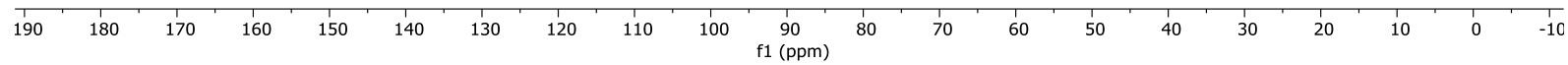

${ }^{19}$ F NMR (376 MHz, DMSO-d 6 ) of compound 24:<smiles>OC#CBr</smiles> 
${ }^{11}$ B NMR (128 MHz, DMSO-d ${ }_{6}$ ) of compound 24:

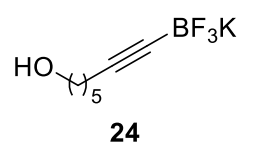

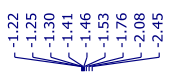
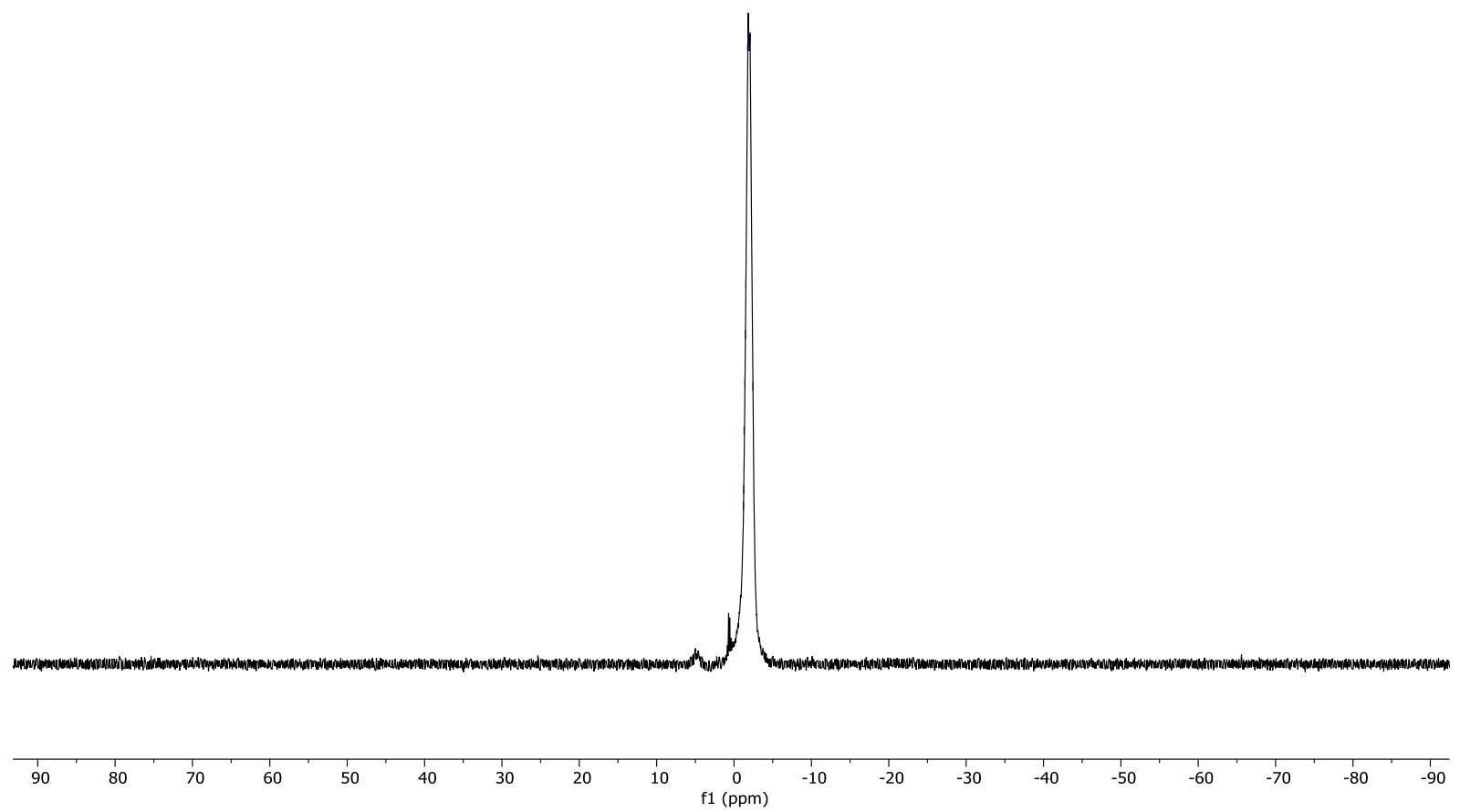

HRMS (ESI/QTOF, negative mode) of compound $\mathbf{2 4}$

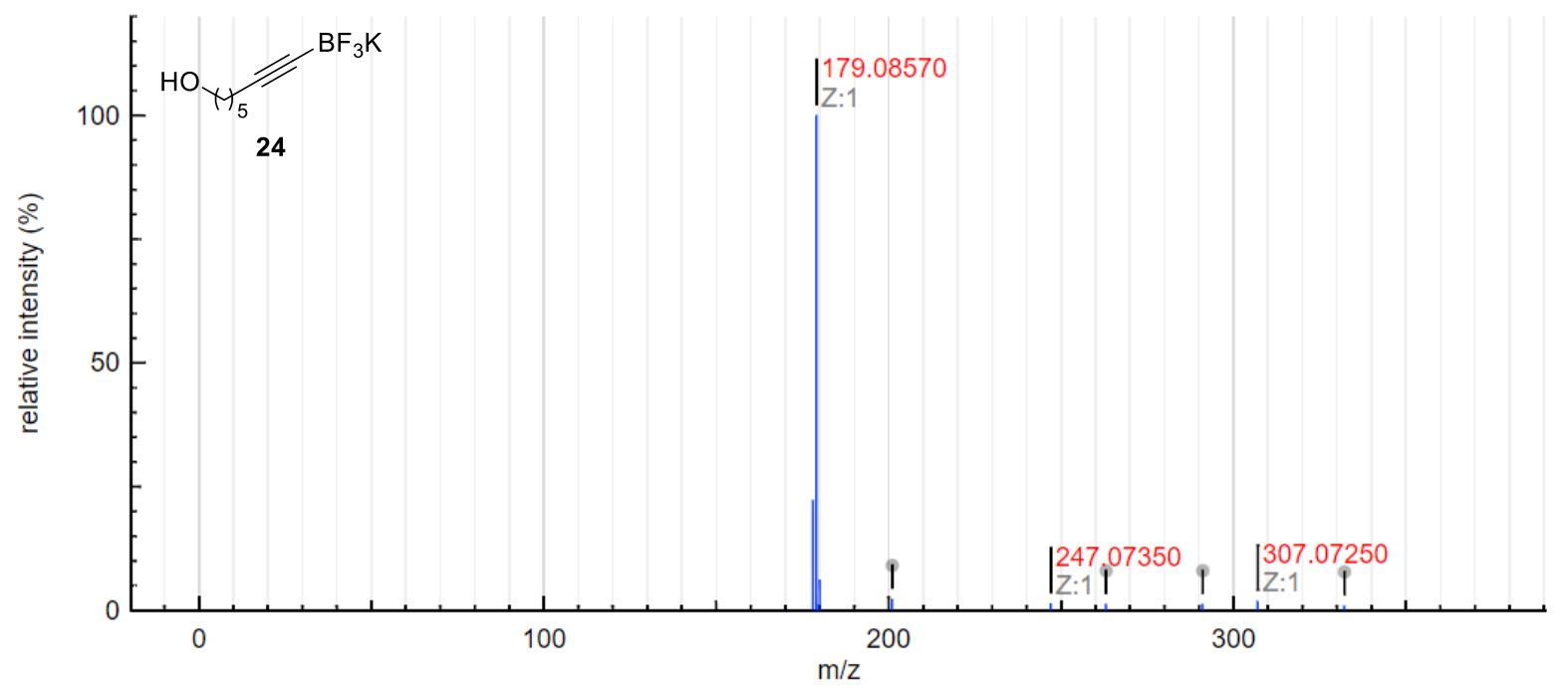

S94 
${ }^{1} \mathrm{H}$ NMR (400 MHz, acetone- $\mathrm{d}_{6}$ ) of compound 25:

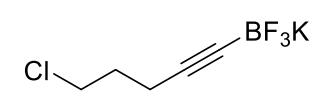

25

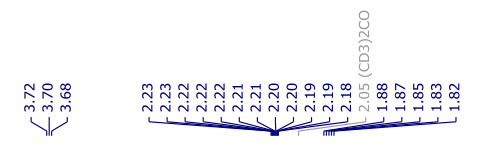

年

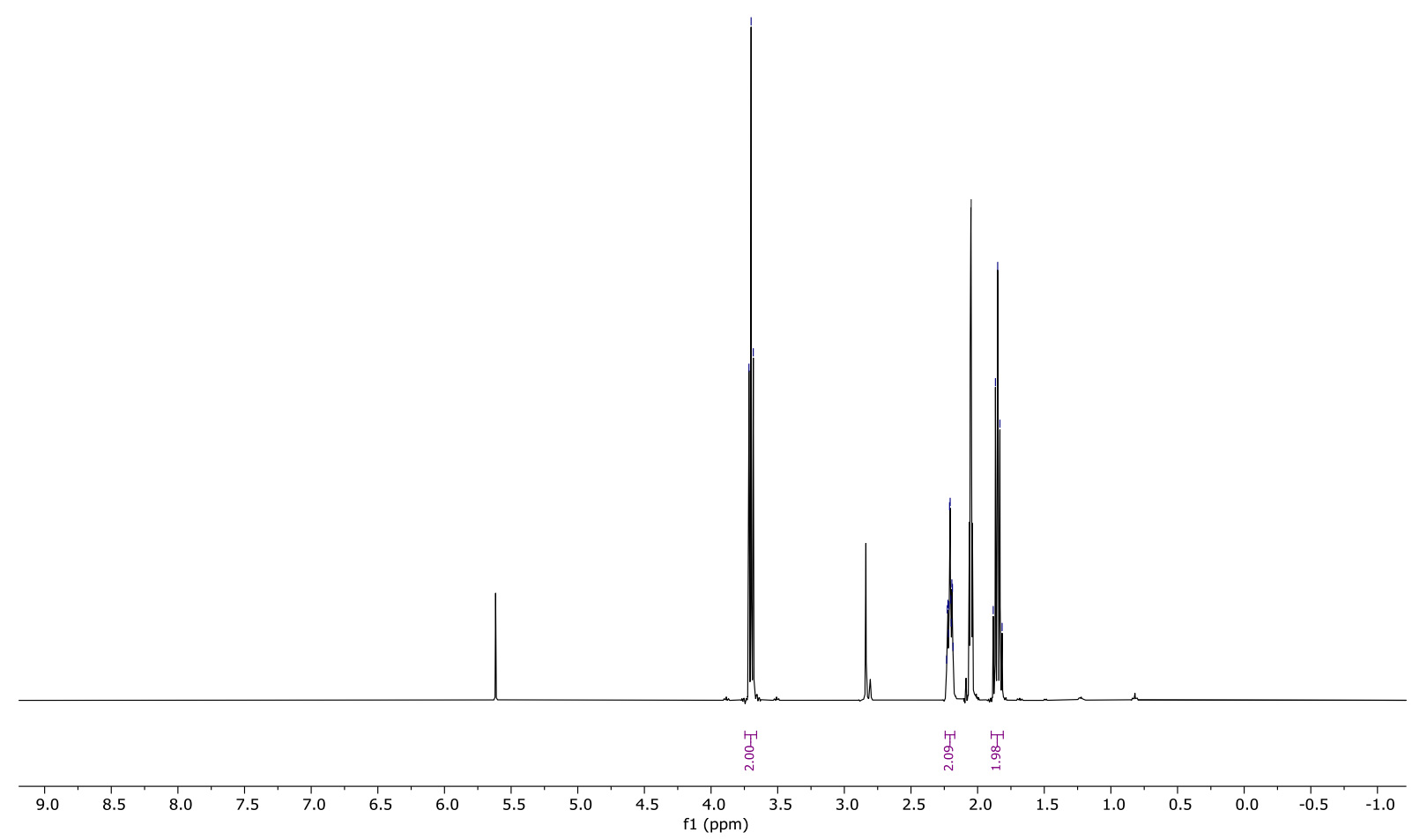

${ }^{13} \mathrm{C}$ NMR (101 MHz, acetone- $\mathrm{d}_{6}$ ) of compound 25:

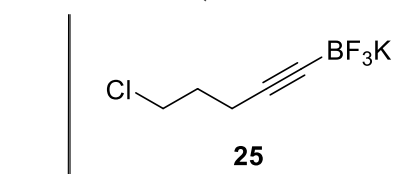


${ }^{19}$ F NMR (376 MHz, acetone- $\left.\mathrm{d}_{6}\right)$ of compound 25:

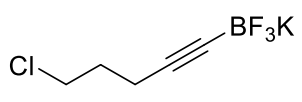

25

\begin{tabular}{rlllllllllllllllllllllllllll}
\hline & 10 & 0 & -10 & -20 & -30 & -40 & -50 & -60 & -70 & -80 & -90 & -100 & -110 & -120 & -130 & -140 & -150 & -160 & -170 & -180 & -190 & -200 & -210 \\
\hline
\end{tabular}

${ }^{1} \mathrm{H}$ NMR (400 MHz, acetone- $\mathrm{d}_{6}$ ) of compound 26:

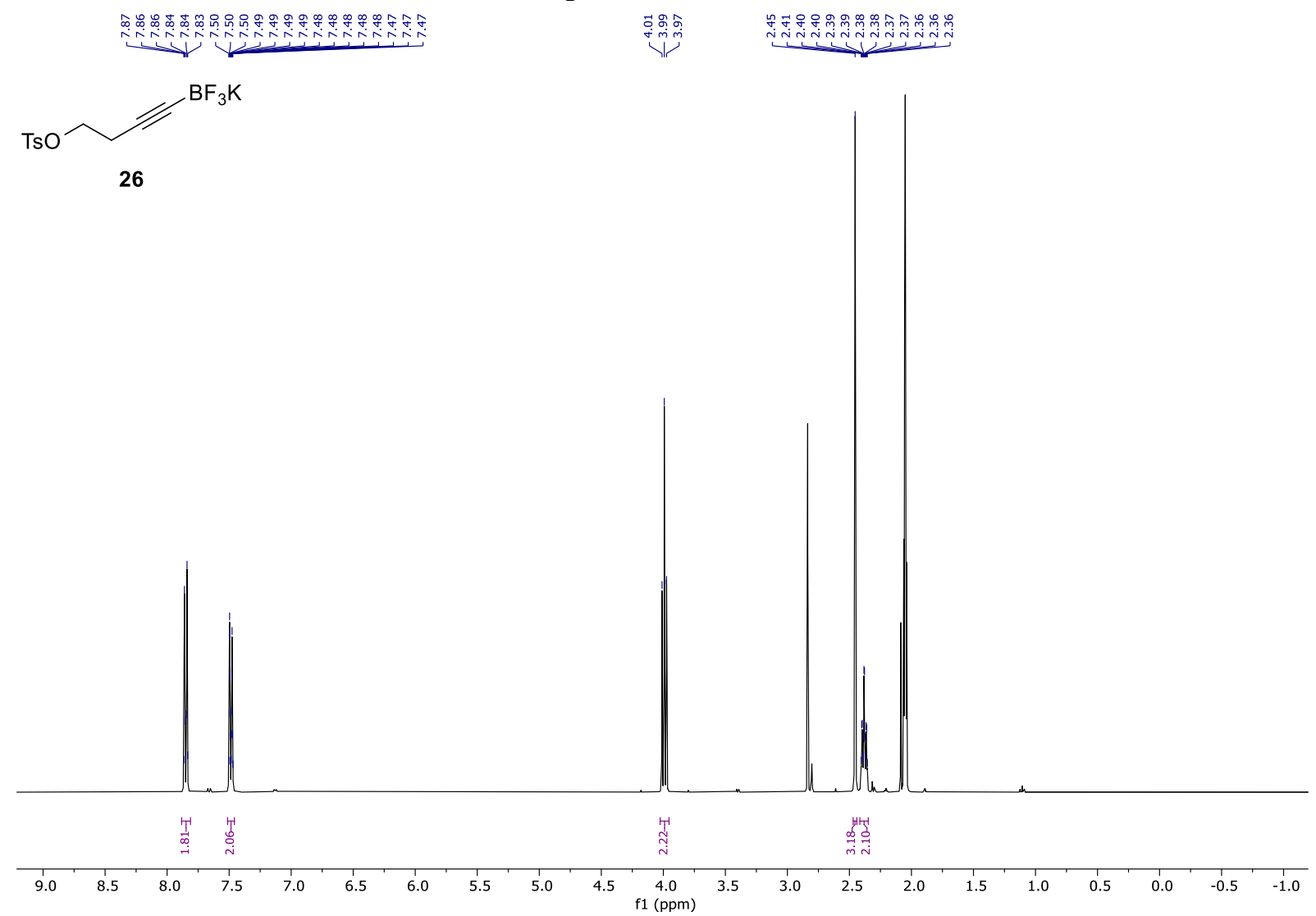



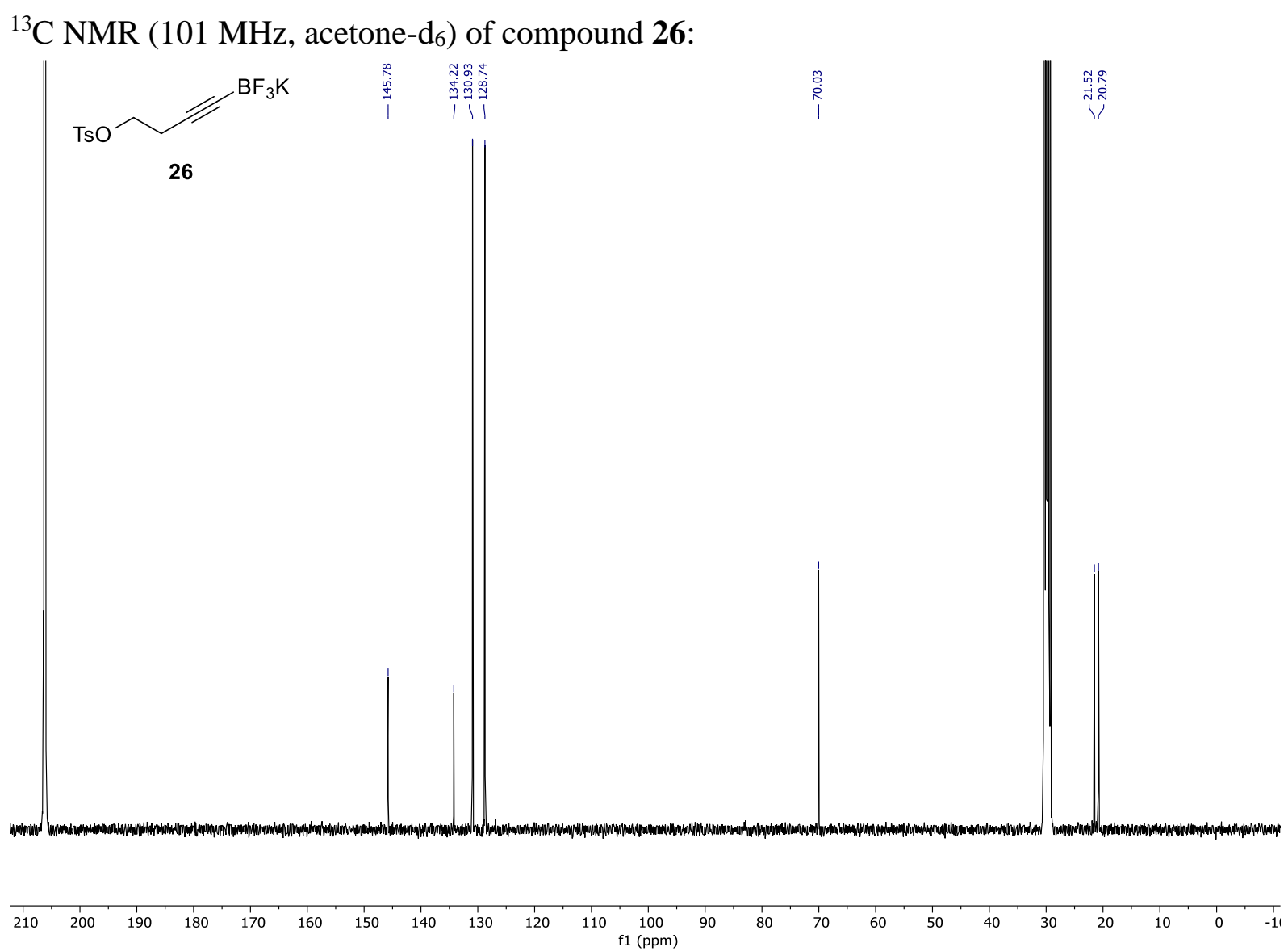

${ }^{19}$ F NMR (376 MHz, acetone- $\mathrm{d}_{6}$ ) of compound 26:

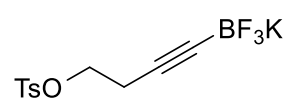

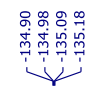

26

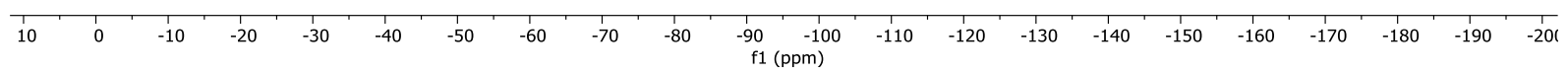

S97 
${ }^{11}$ B NMR (128 MHz, acetone- $\mathrm{d}_{6}$ ) of compound 26:

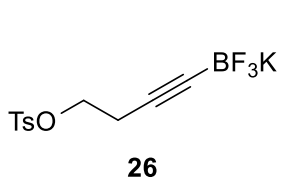

ำำ

26

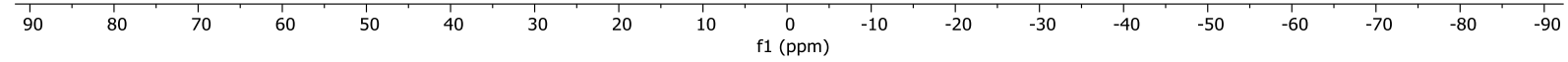

HRMS (ESI/QTOF, negative mode) of compound 26:

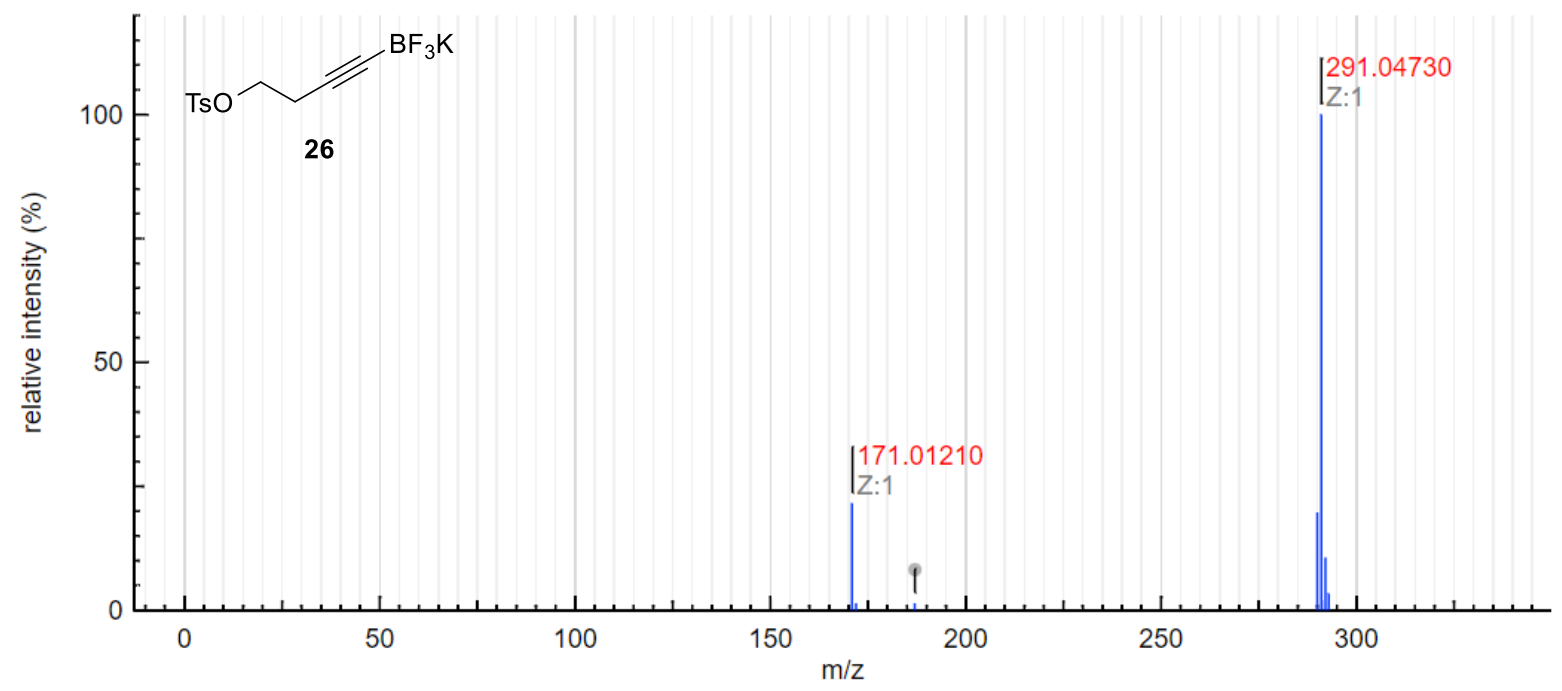


${ }^{1} \mathrm{H}$ NMR (400 MHz, acetone-d ${ }_{6}$ ) of compound 27:
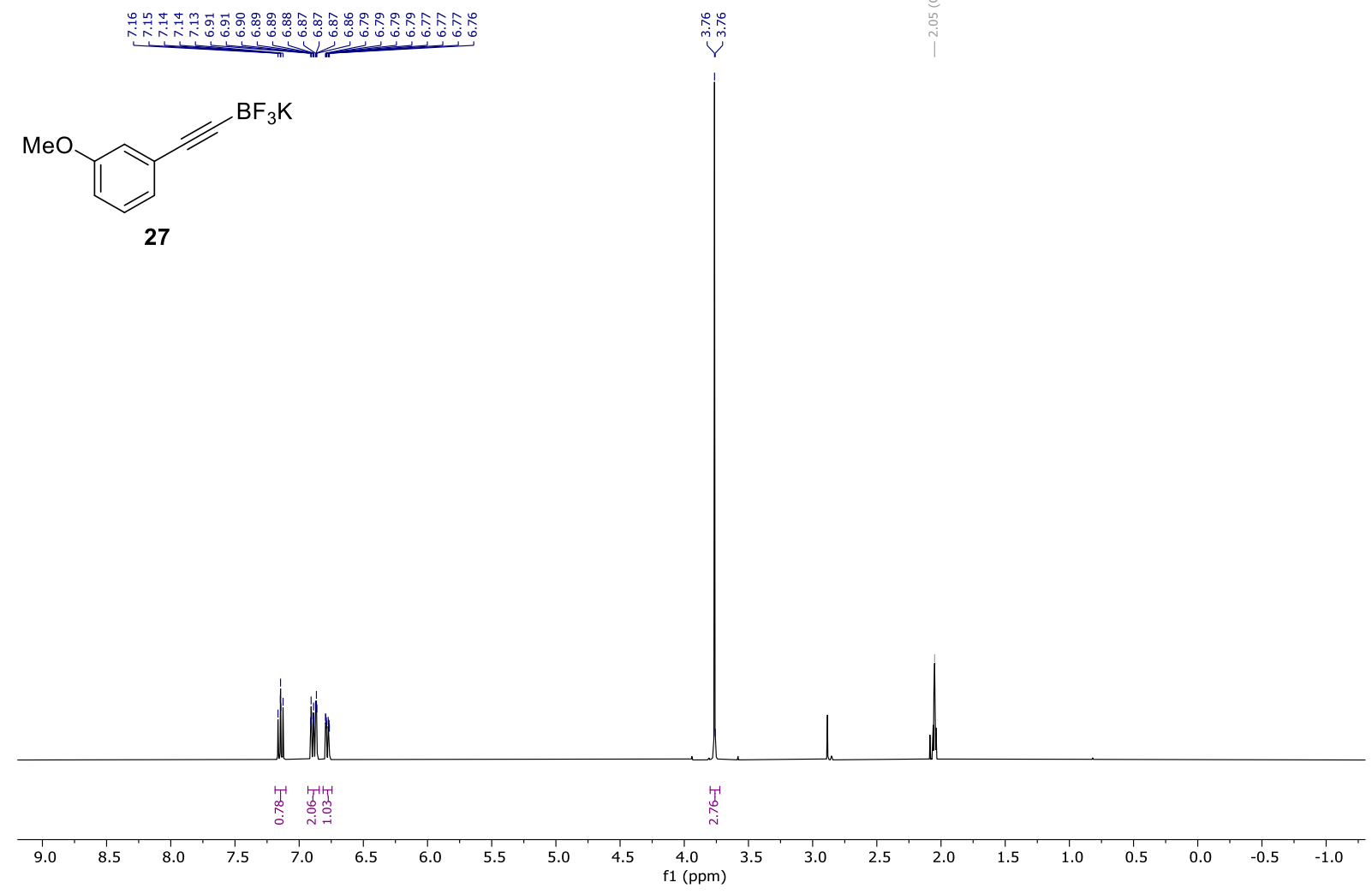

${ }^{13} \mathrm{C}$ NMR (101 MHz, acetone-d 6 ) of compound 27:

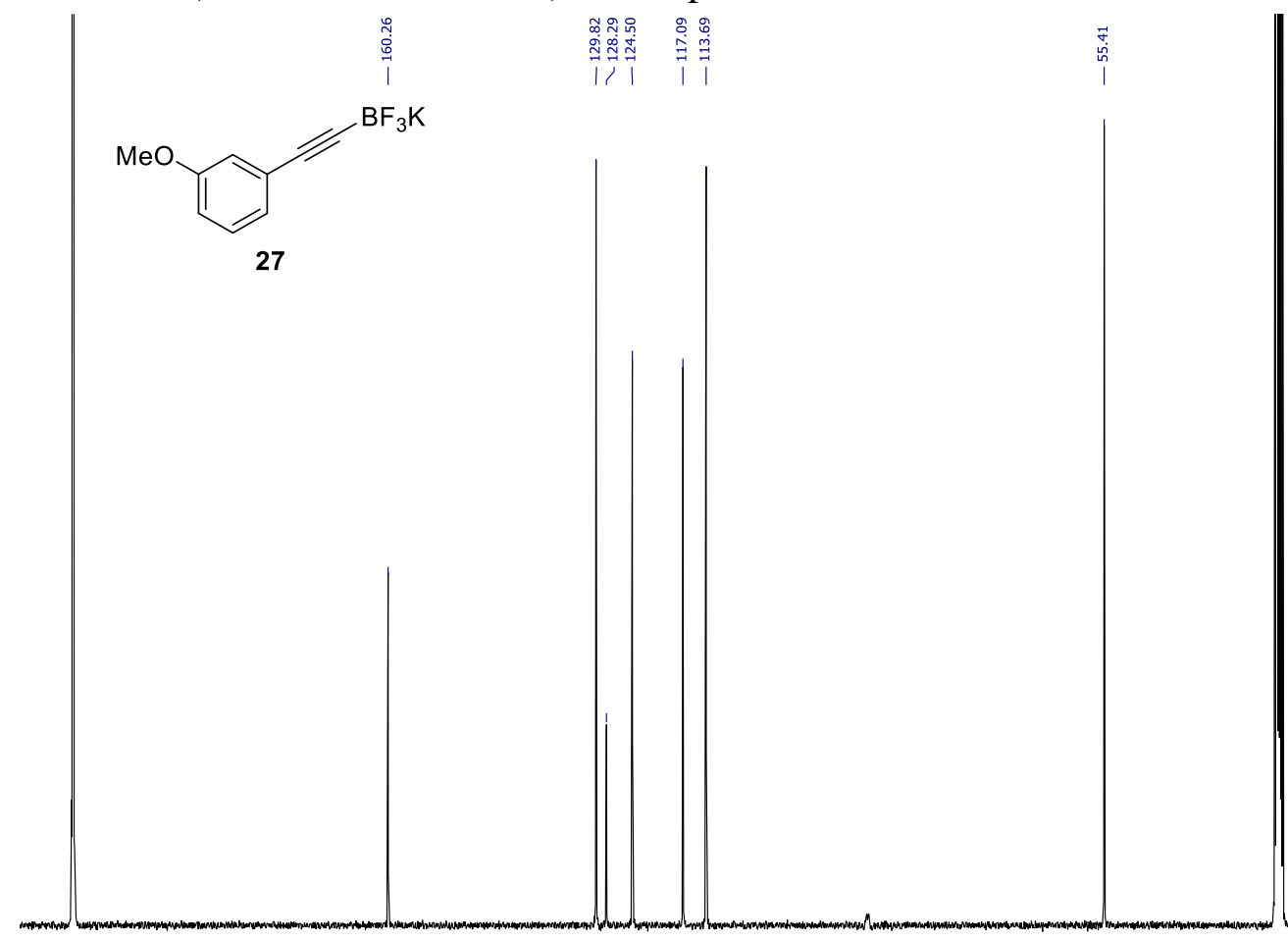

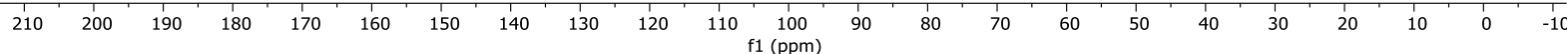


${ }^{19}$ F NMR (376 MHz, acetone- $\left.\mathrm{d}_{6}\right)$ of compound 27:

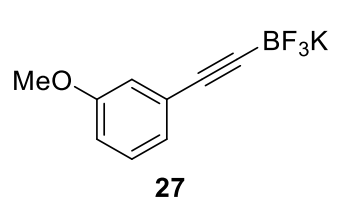

${ }^{1} \mathrm{H}$ NMR (400 MHz, acetone- $\mathrm{d}_{6}$ ) of compound 29:

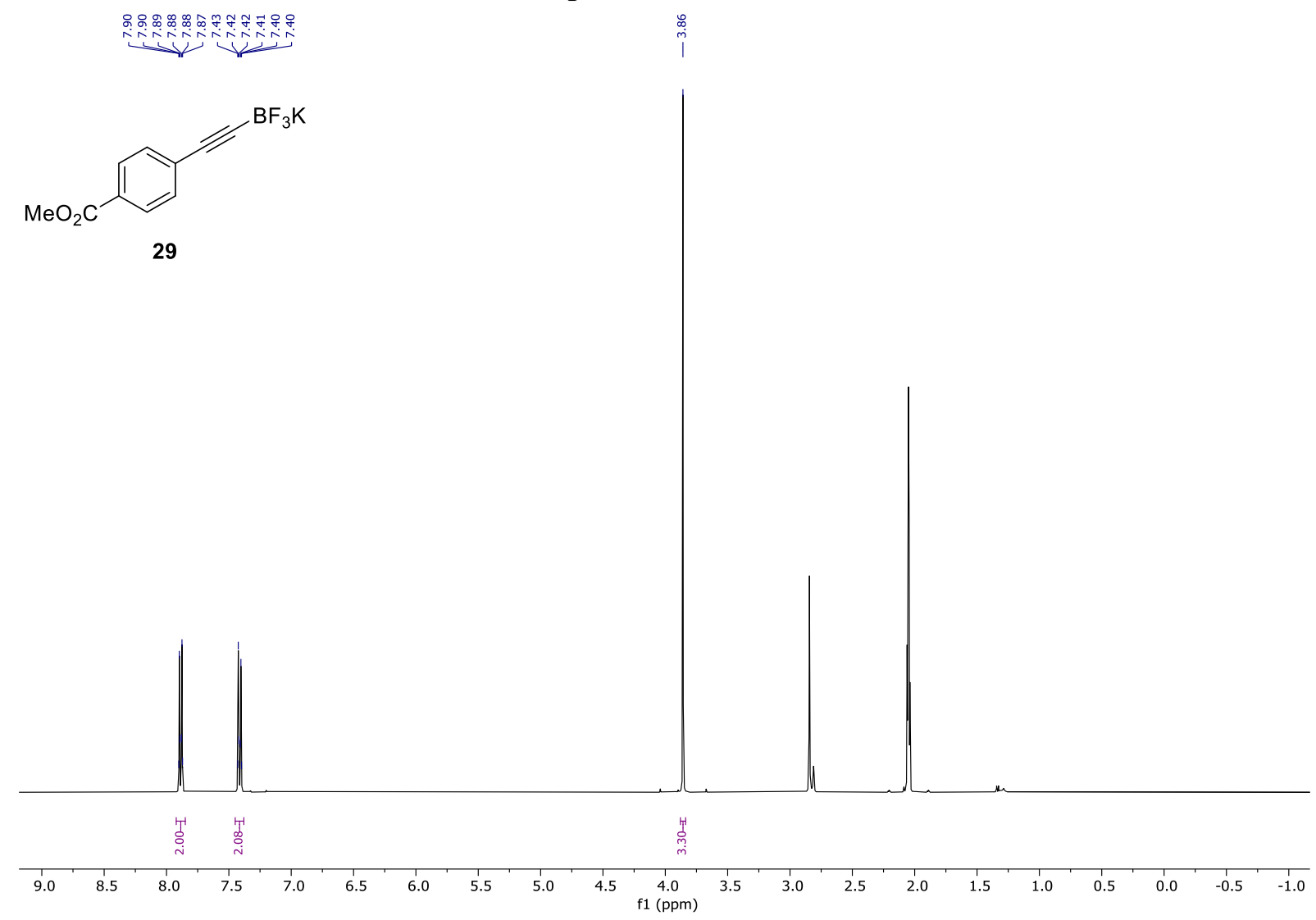


${ }^{13} \mathrm{C}$ NMR (101 MHz, acetone- $\mathrm{d}_{6}$ ) of compound 29:
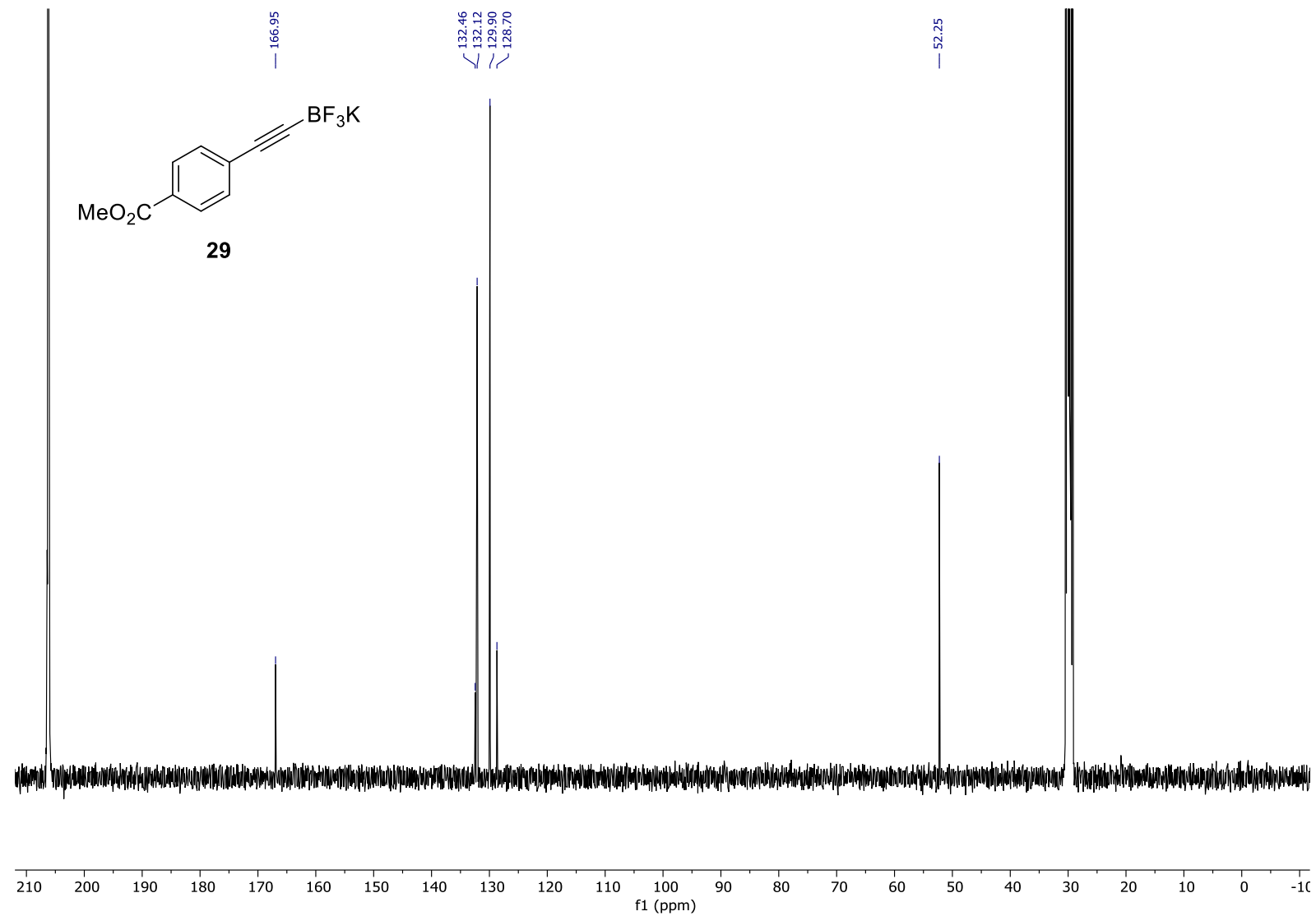

${ }^{19}$ F NMR (376 MHz, acetone- $\mathrm{d}_{6}$ ) of compound 29:

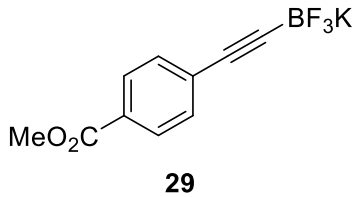


${ }^{11}$ B NMR (128 MHz, acetone- $\left.\mathrm{d}_{6}\right)$ of compound 29:

ํㅗㅇำ

$\mathrm{MeO}_{2} \mathrm{C}$

29

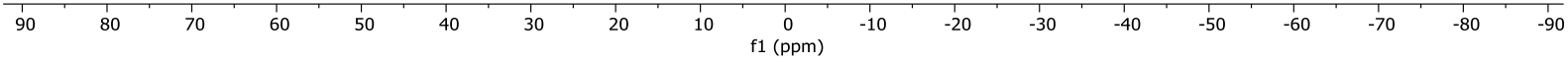

${ }^{1} \mathrm{H}$ NMR (400 MHz, DMSO-d 6 ) of compound 30:
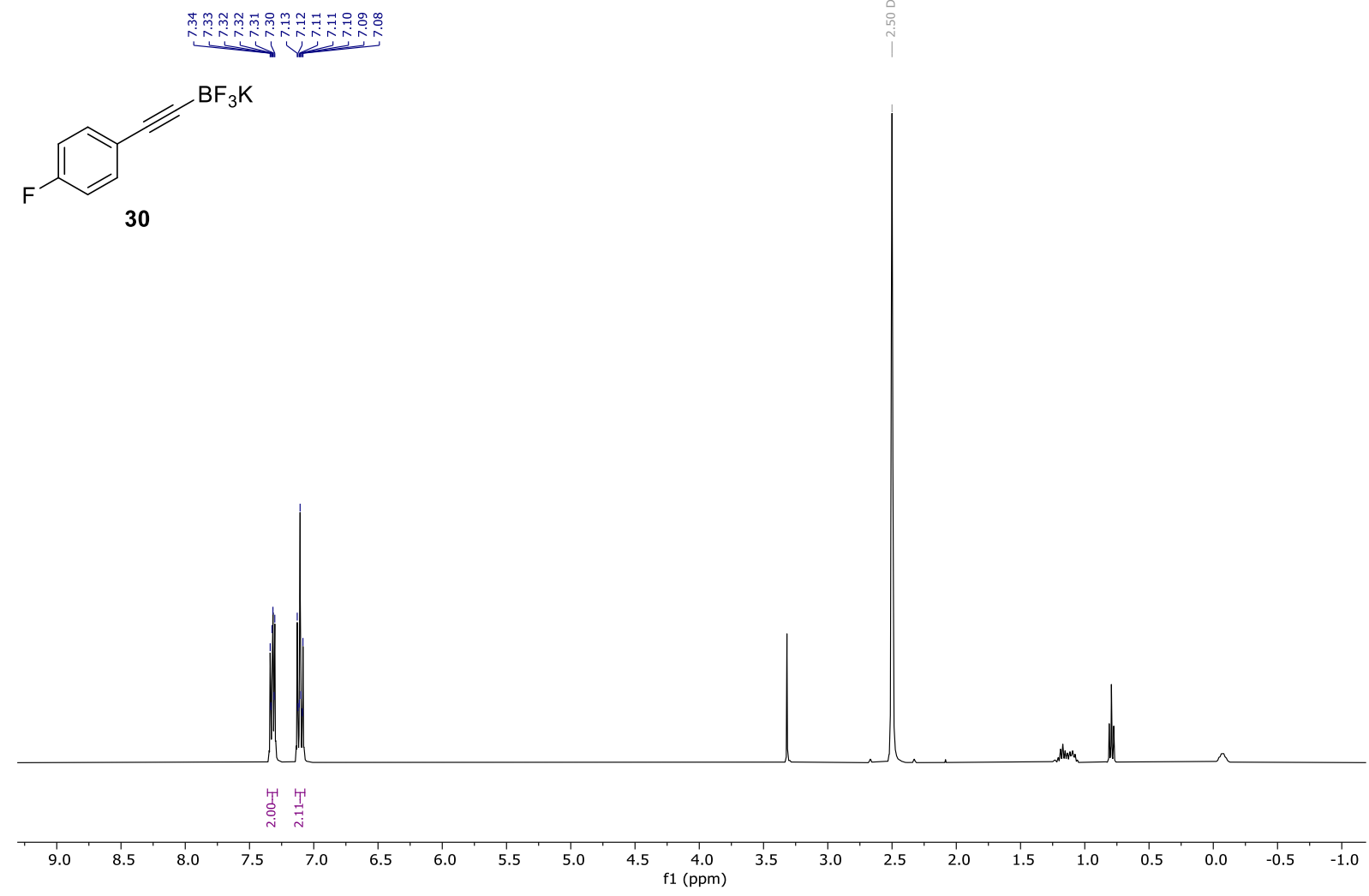
${ }^{1} \mathrm{H}$ NMR (400 MHz, acetone- $\mathrm{d}_{6}$ ) of compound 30:

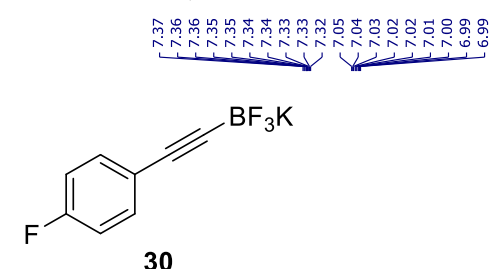

30

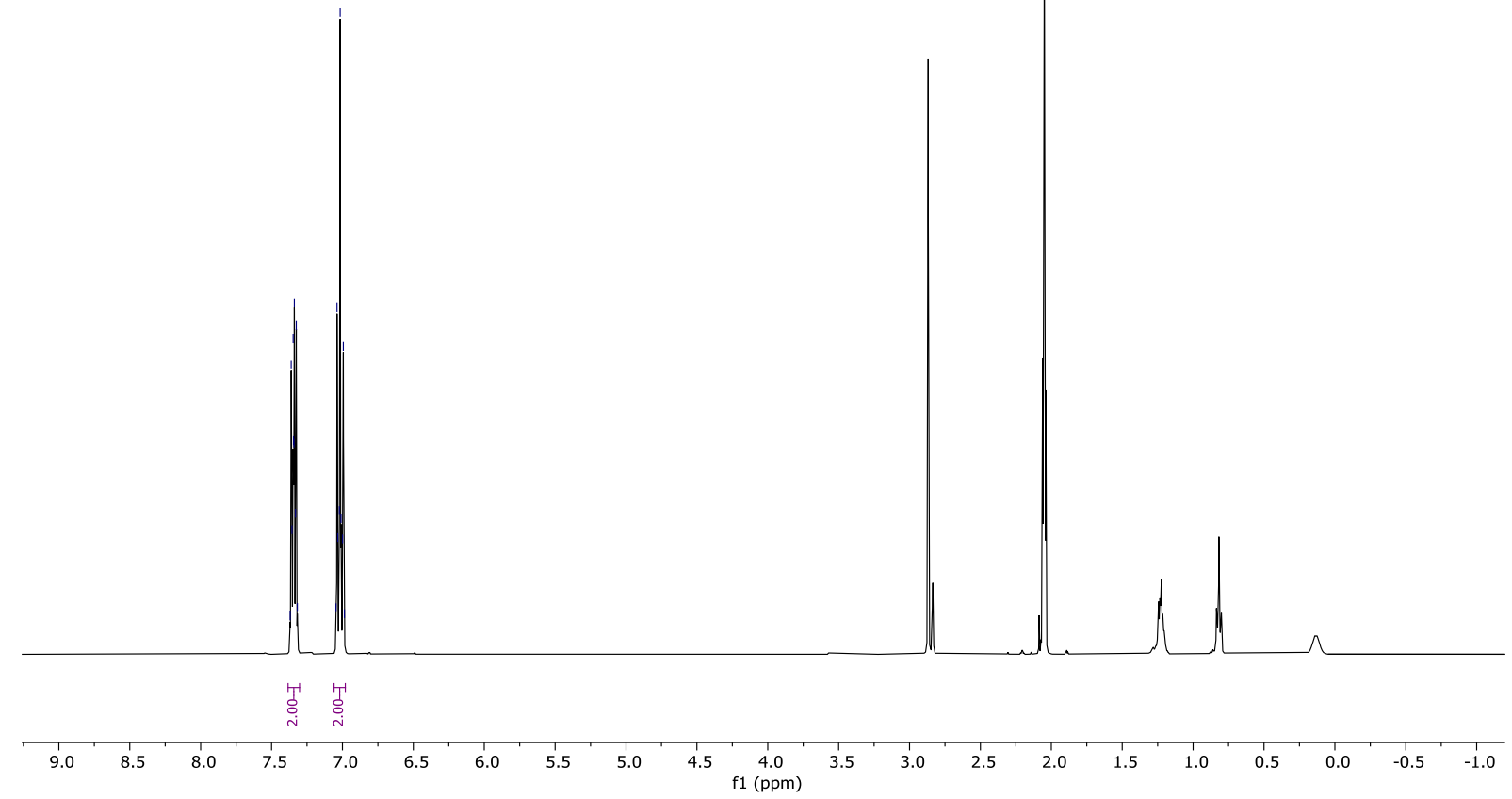

${ }^{13} \mathrm{C}$ NMR (101 MHz, acetone- $\mathrm{d}_{6}$ ) of compound 30:
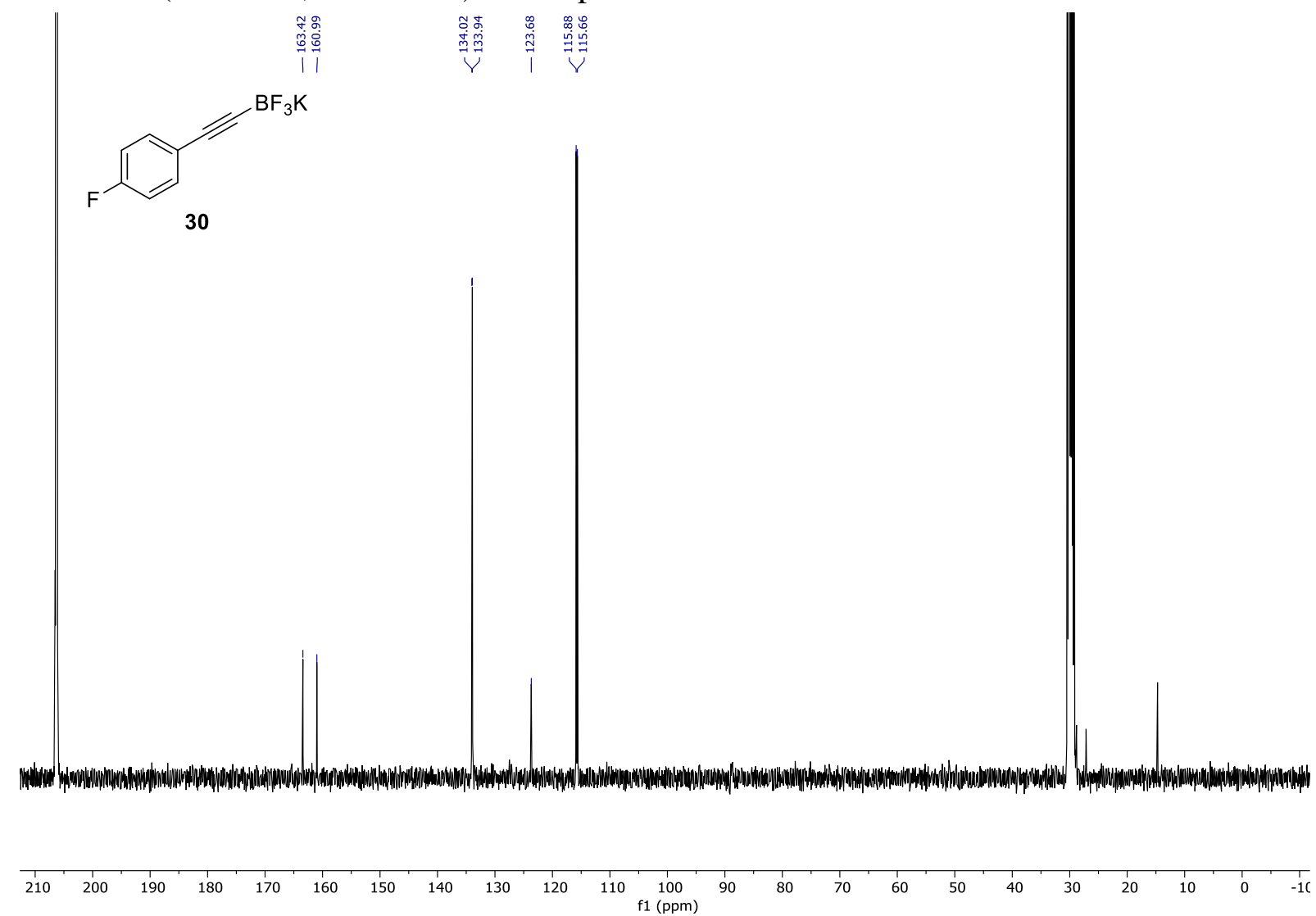
${ }^{19}$ F NMR (376 MHz, acetone- $\left.\mathrm{d}_{6}\right)$ of compound 30:
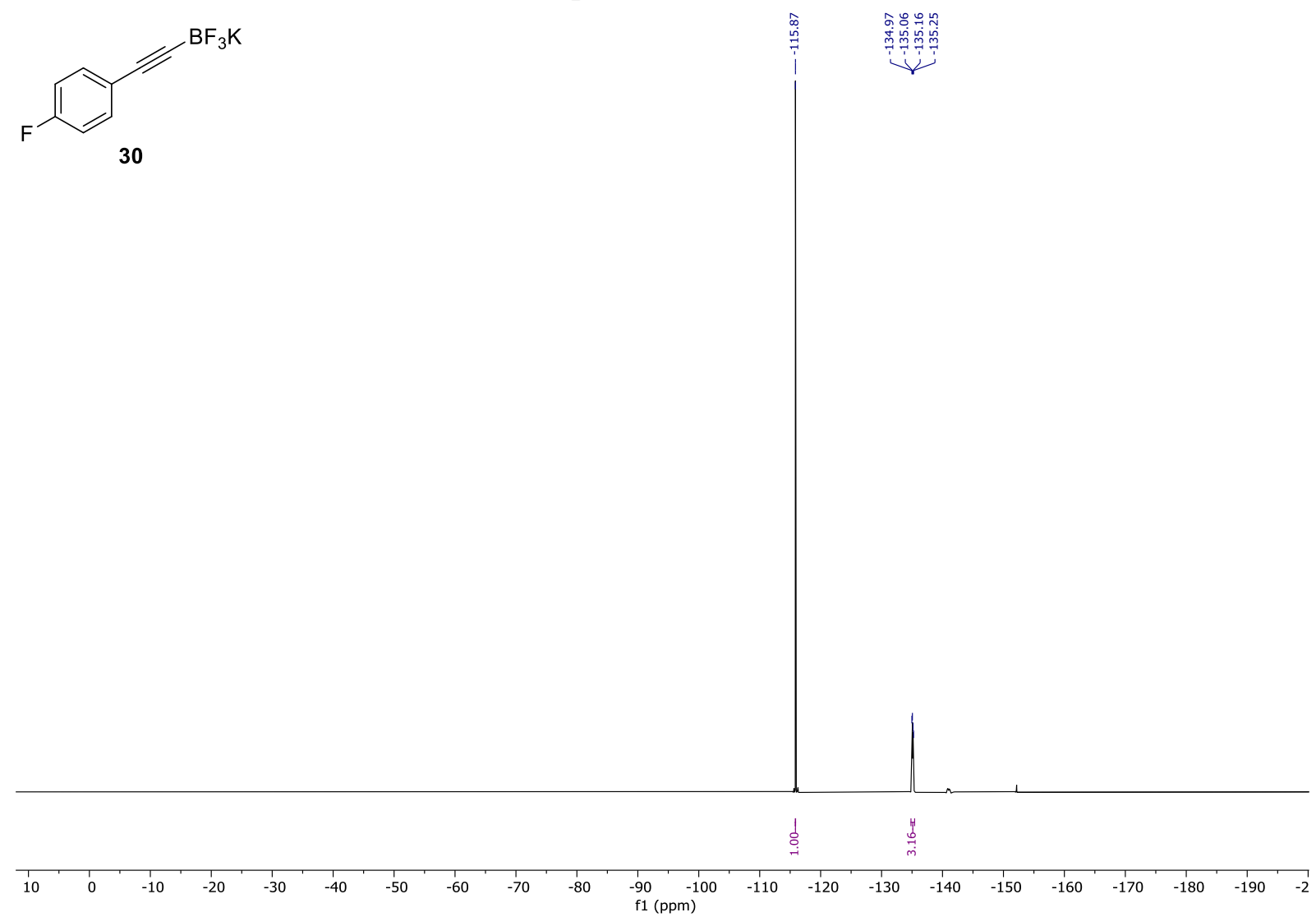

${ }^{1} \mathrm{H}$ NMR (400 MHz, DMSO- $\mathrm{d}_{6}$ ) of compound 32:

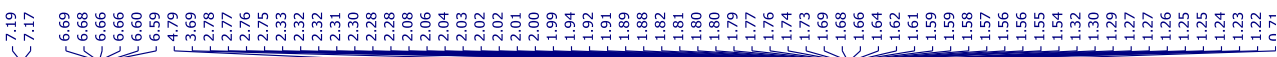

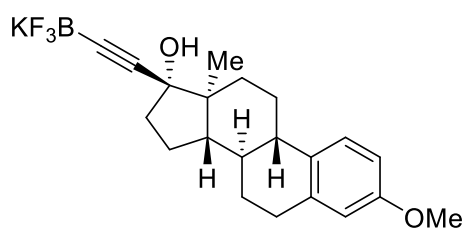

32

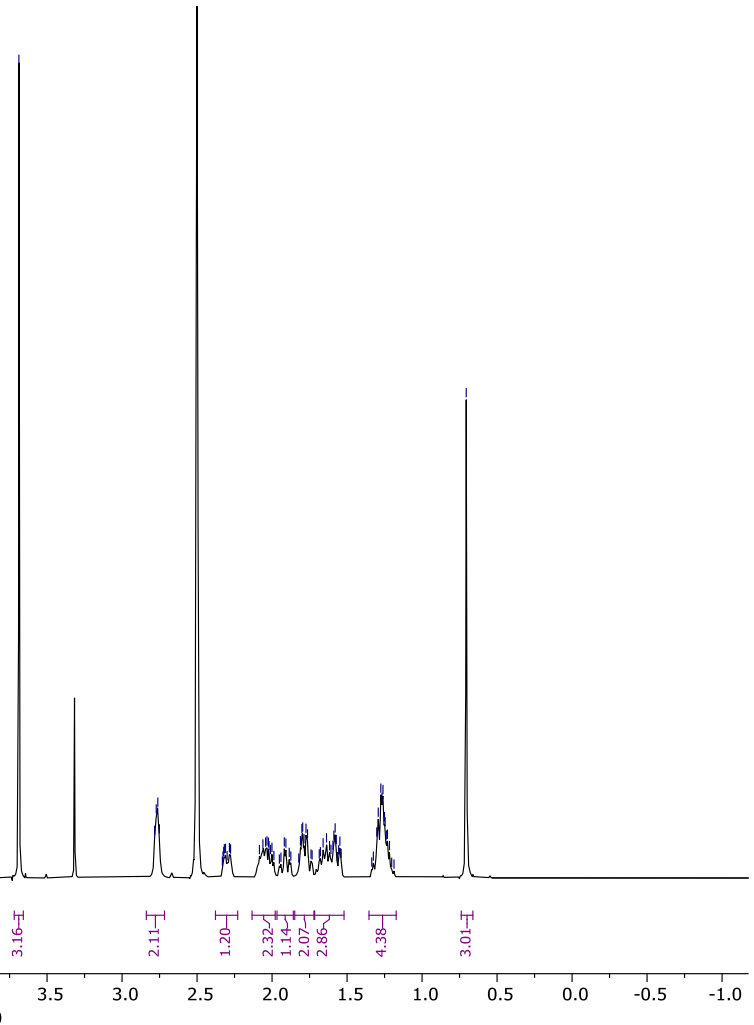


${ }^{13} \mathrm{C}$ NMR (101 MHz, DMSO $\left.-\mathrm{d}_{6}\right)$ of compound 32:

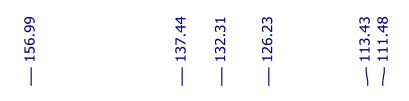

要

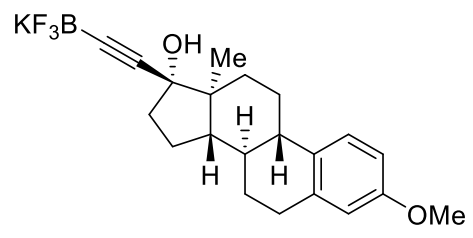

32
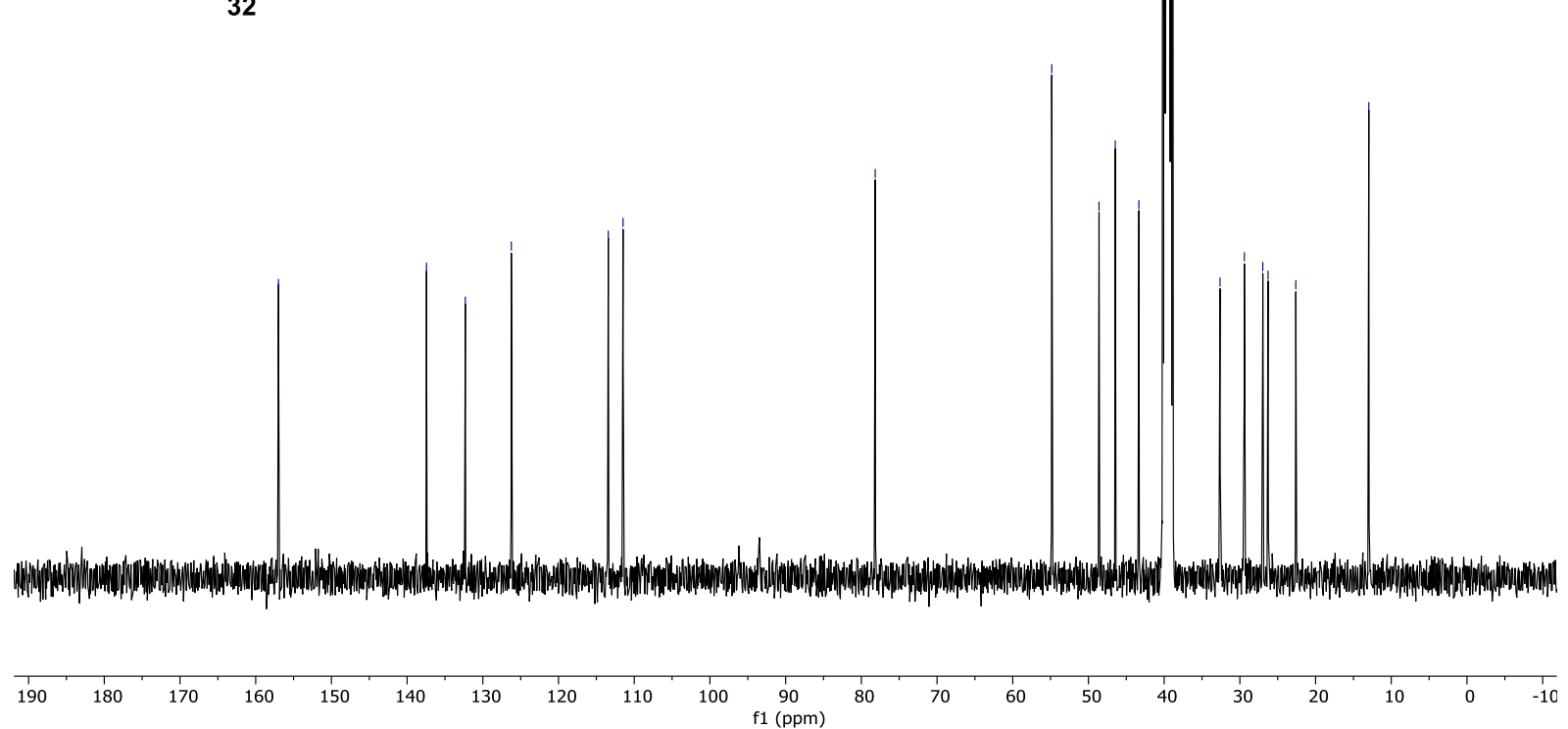

${ }^{19} \mathrm{~F}$ NMR (376 MHz, DMSO $-\mathrm{d}_{6}$ ) of compound 32:

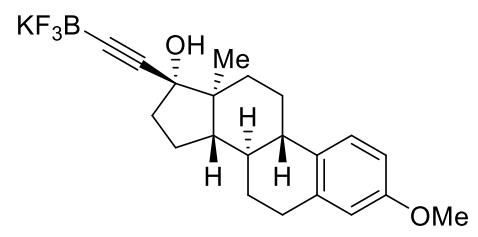

32
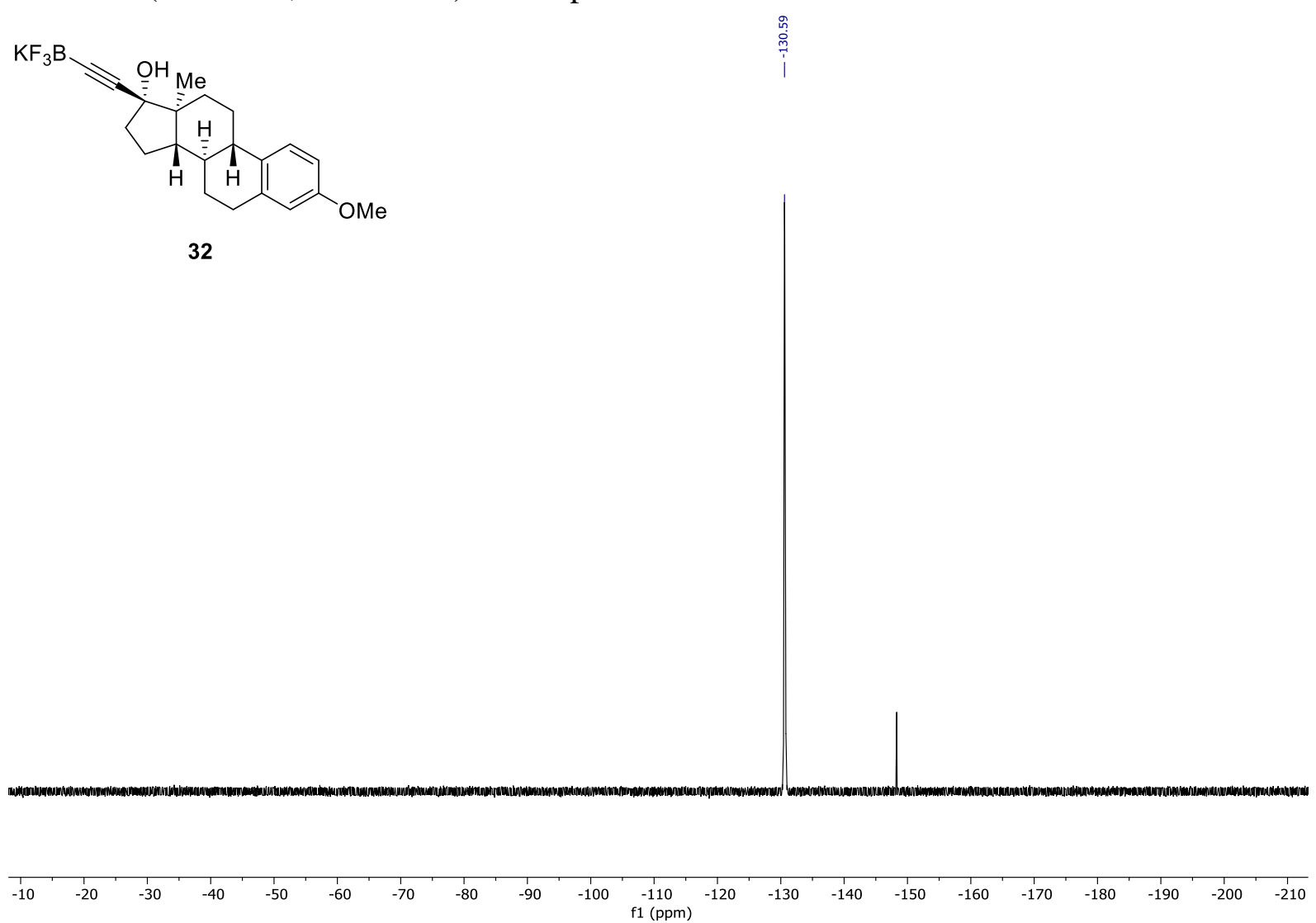

S105 
${ }^{11}$ B NMR (128 MHz, DMSO $\left.-\mathrm{d}_{6}\right)$ of compound 32:

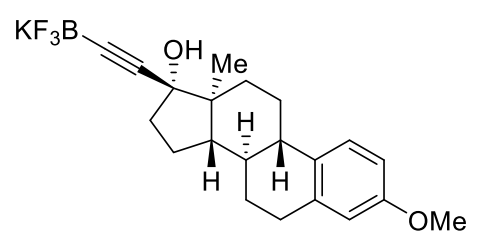

32

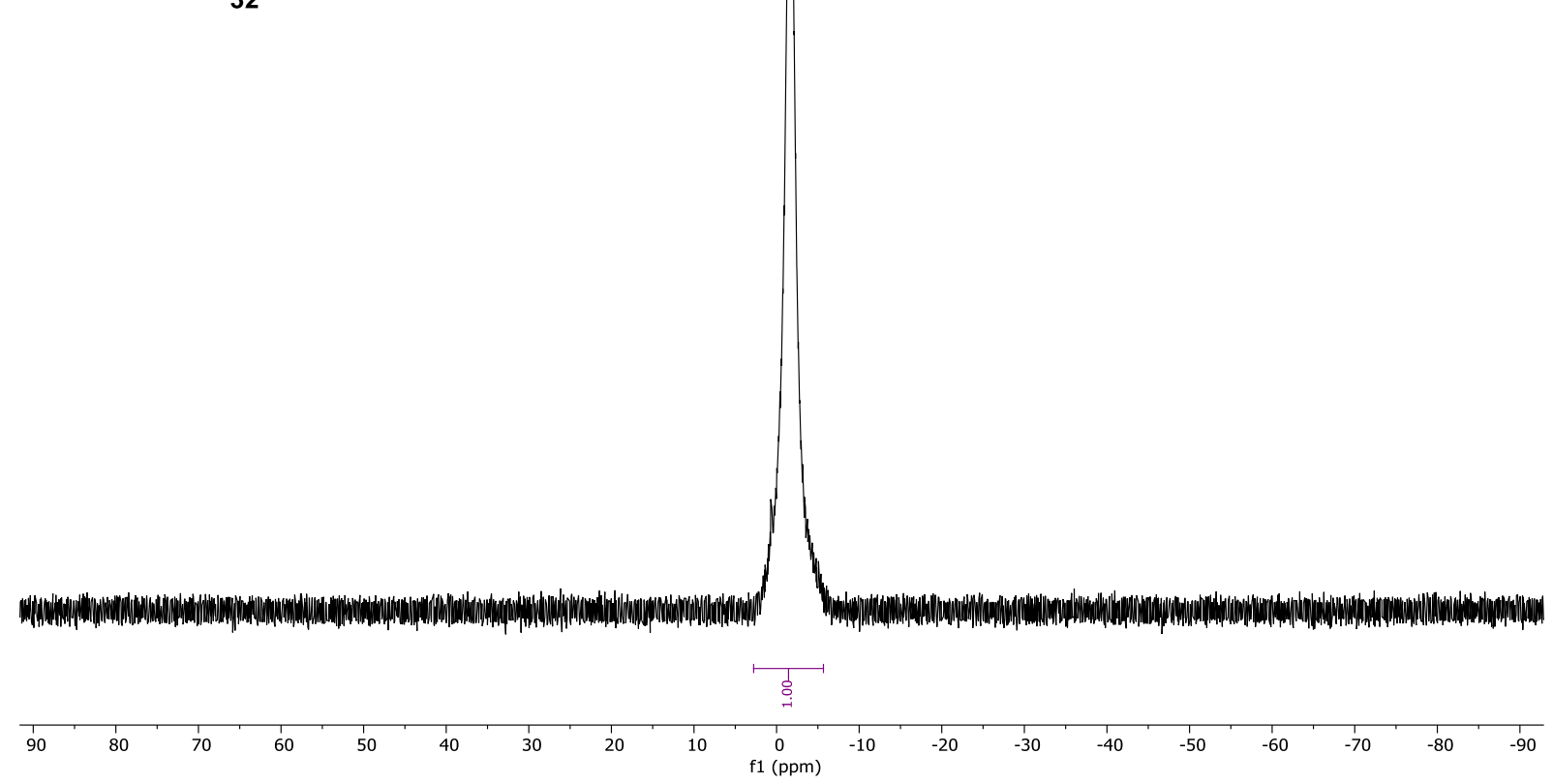

${ }^{1} \mathrm{H}$ NMR (400 MHz, acetone- $\mathrm{d}_{6}$ ) of compound 34: $\equiv \mathrm{BF}_{3} \mathrm{~K}$

34

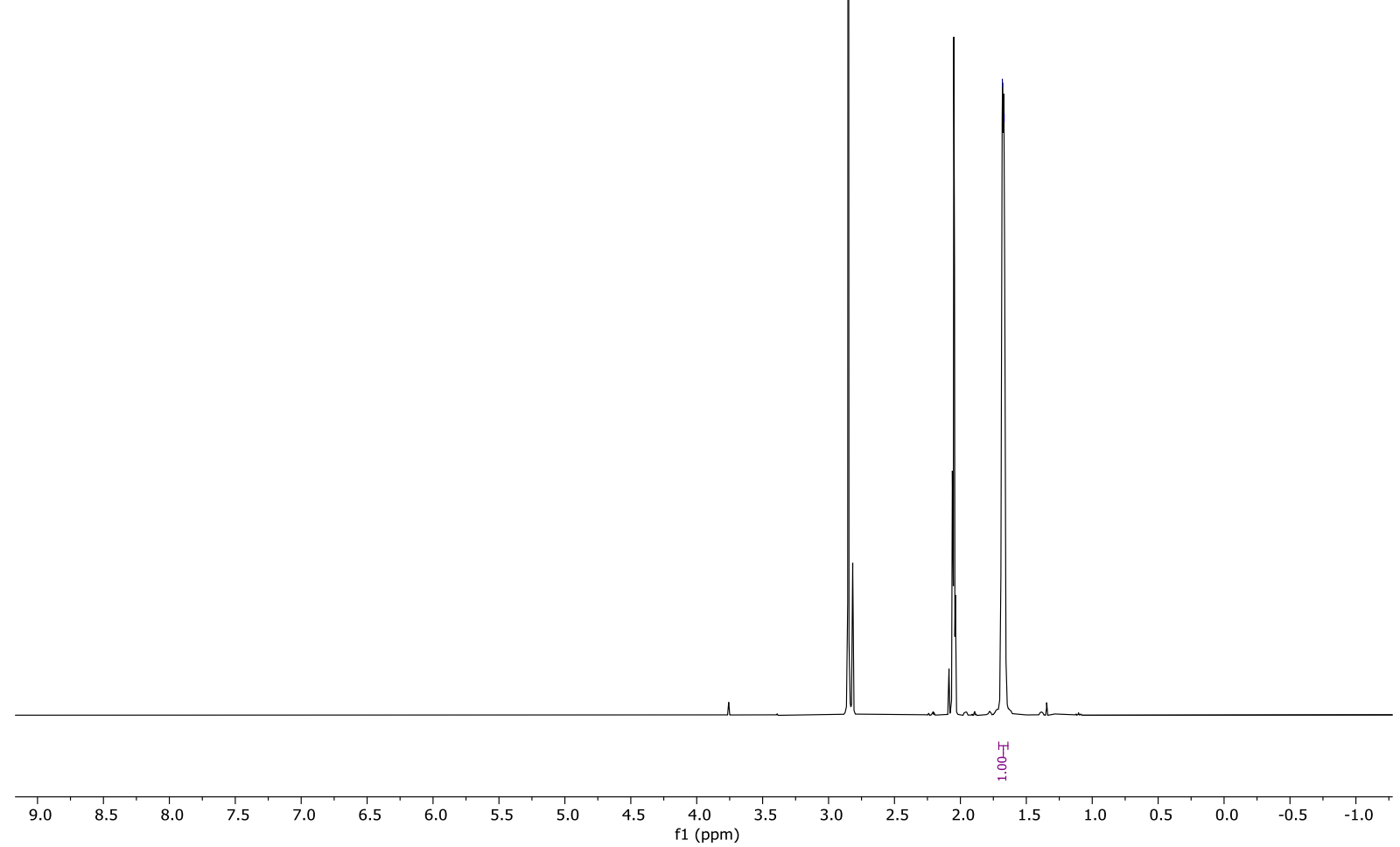


${ }^{13} \mathrm{C}$ NMR (101 MHz, acetone- $\left.\mathrm{d}_{6}\right)$ of compound 34:
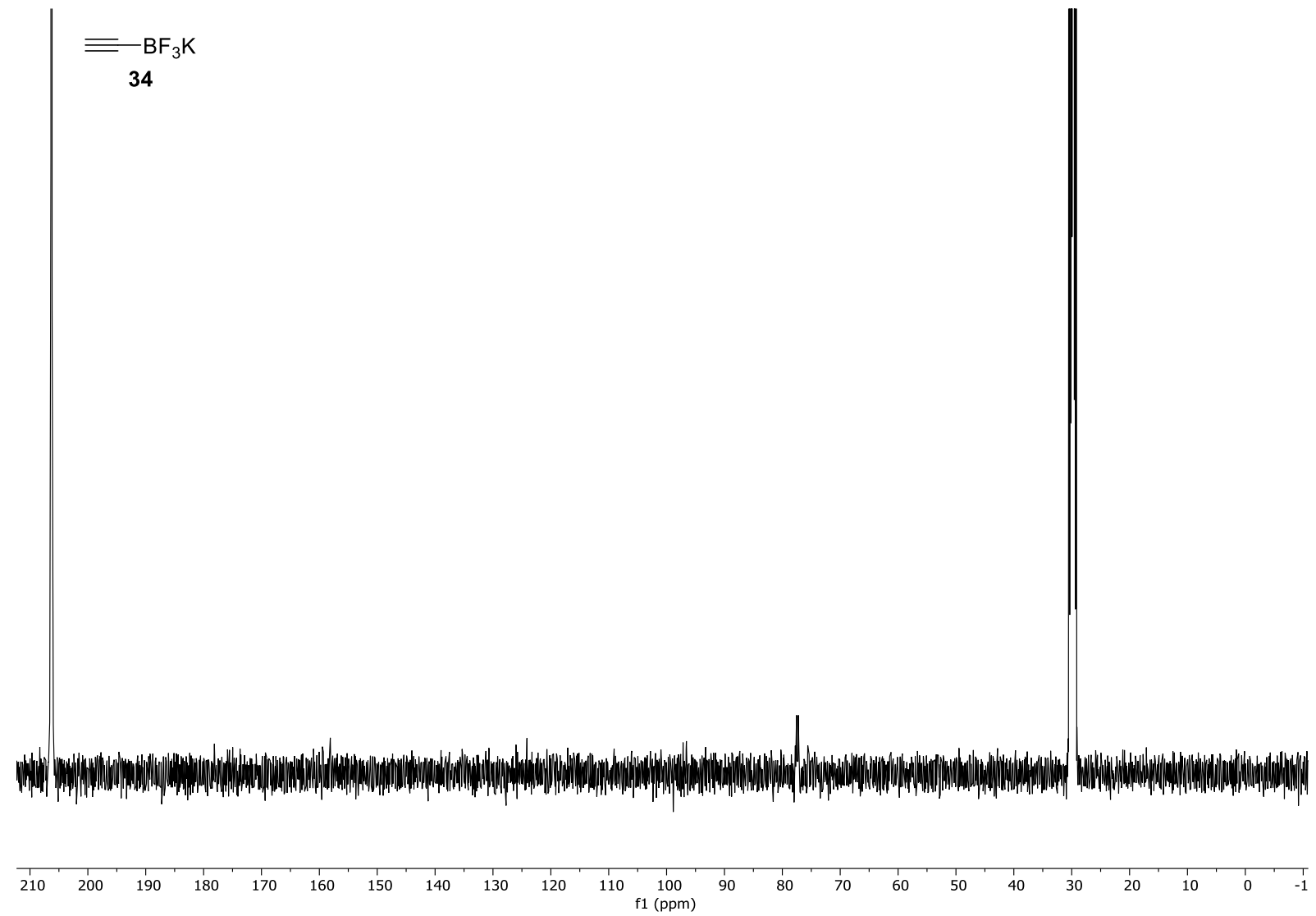

${ }^{19}$ F NMR (376 MHz, acetone-d 6 ) of compound 34:

$$
\equiv \mathrm{BF}_{34} \mathrm{~K}
$$

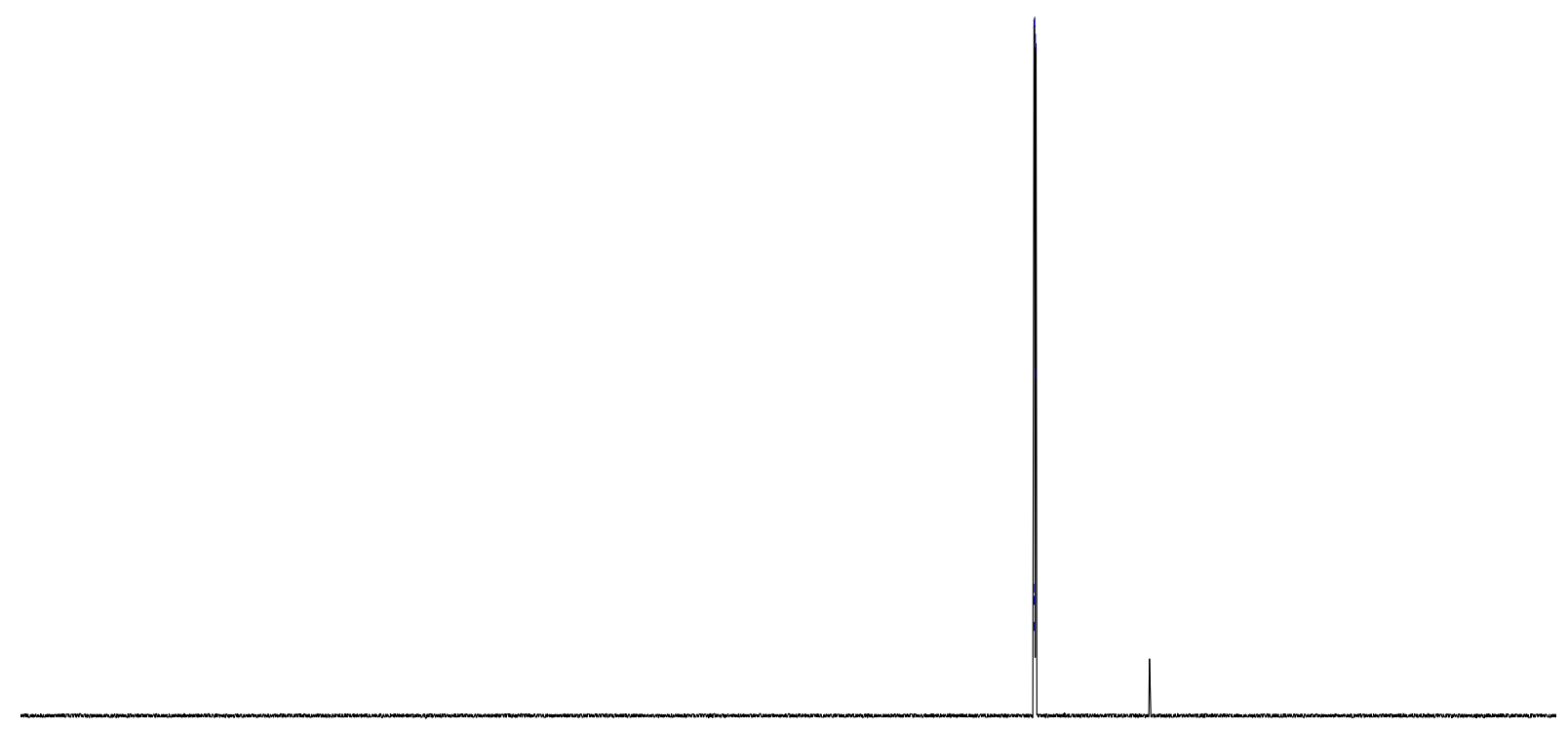

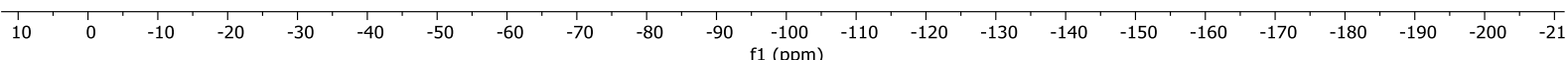


${ }^{11}$ B NMR (128 MHz, acetone- $\left.\mathrm{d}_{6}\right)$ of compound 34:

$$
\equiv \mathrm{BF}_{3} \mathrm{~K}
$$

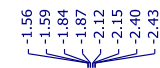

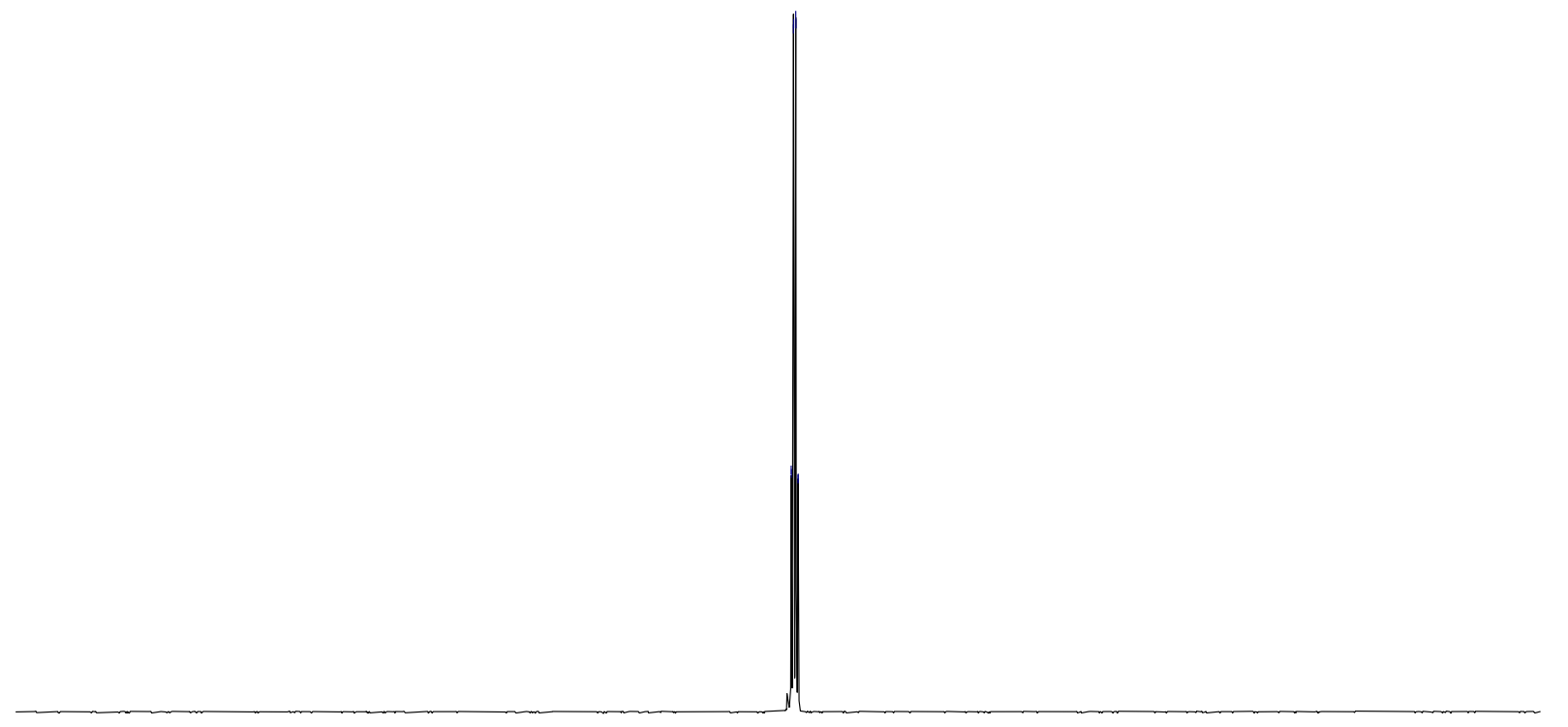

\begin{tabular}{rllllllllllllllllllll}
\hline 10 & 80 & 70 & 60 & 50 & 40 & 30 & 20 & 10 & $\begin{array}{c}1 \\
0\end{array}$ & -10 & -20 & -30 & -40 & -50 & -60 & -70 & -80 & -90
\end{tabular}

HRMS (nanochip-ESI/LTQ-Orbitrap, negative mode) of compound 34:

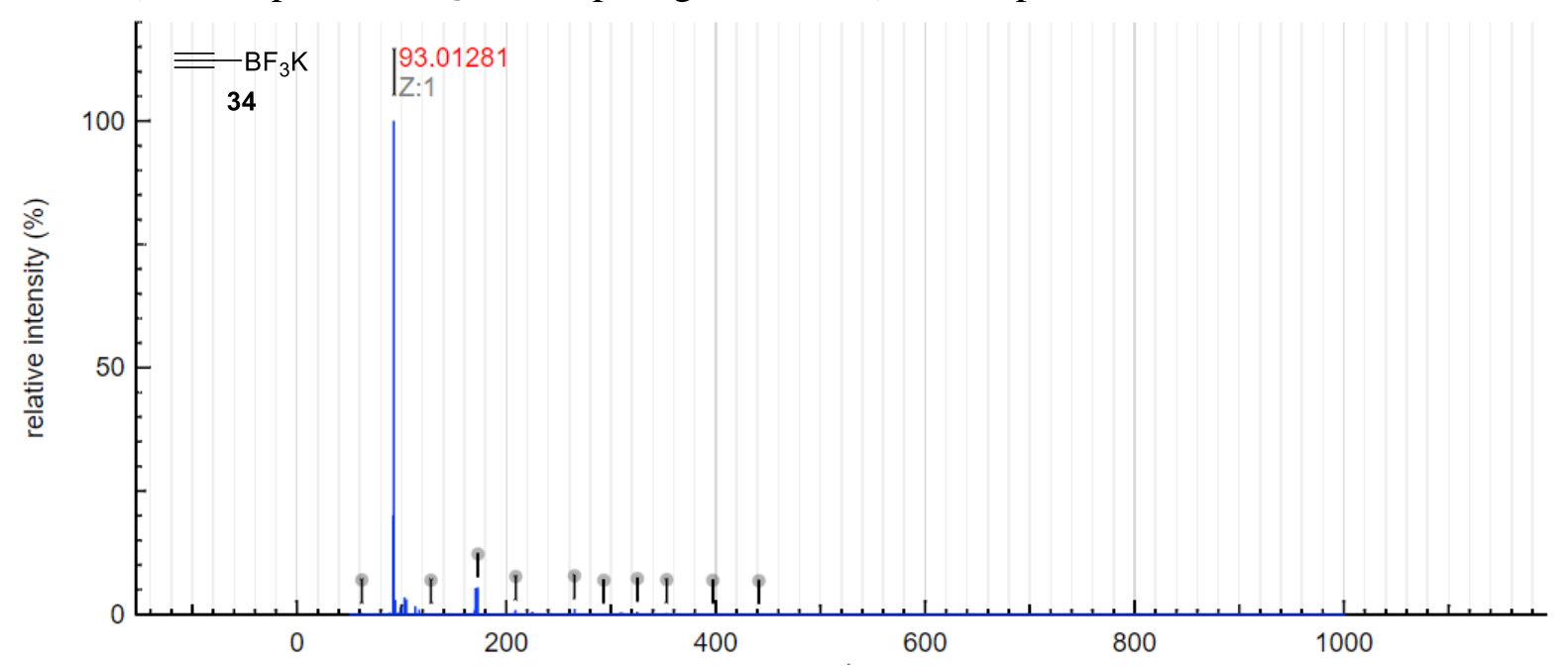


${ }^{1} \mathrm{H}$ NMR (400 MHz, acetone-d 6 ) of compound 37:

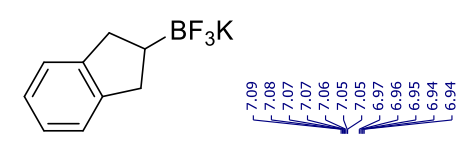

37
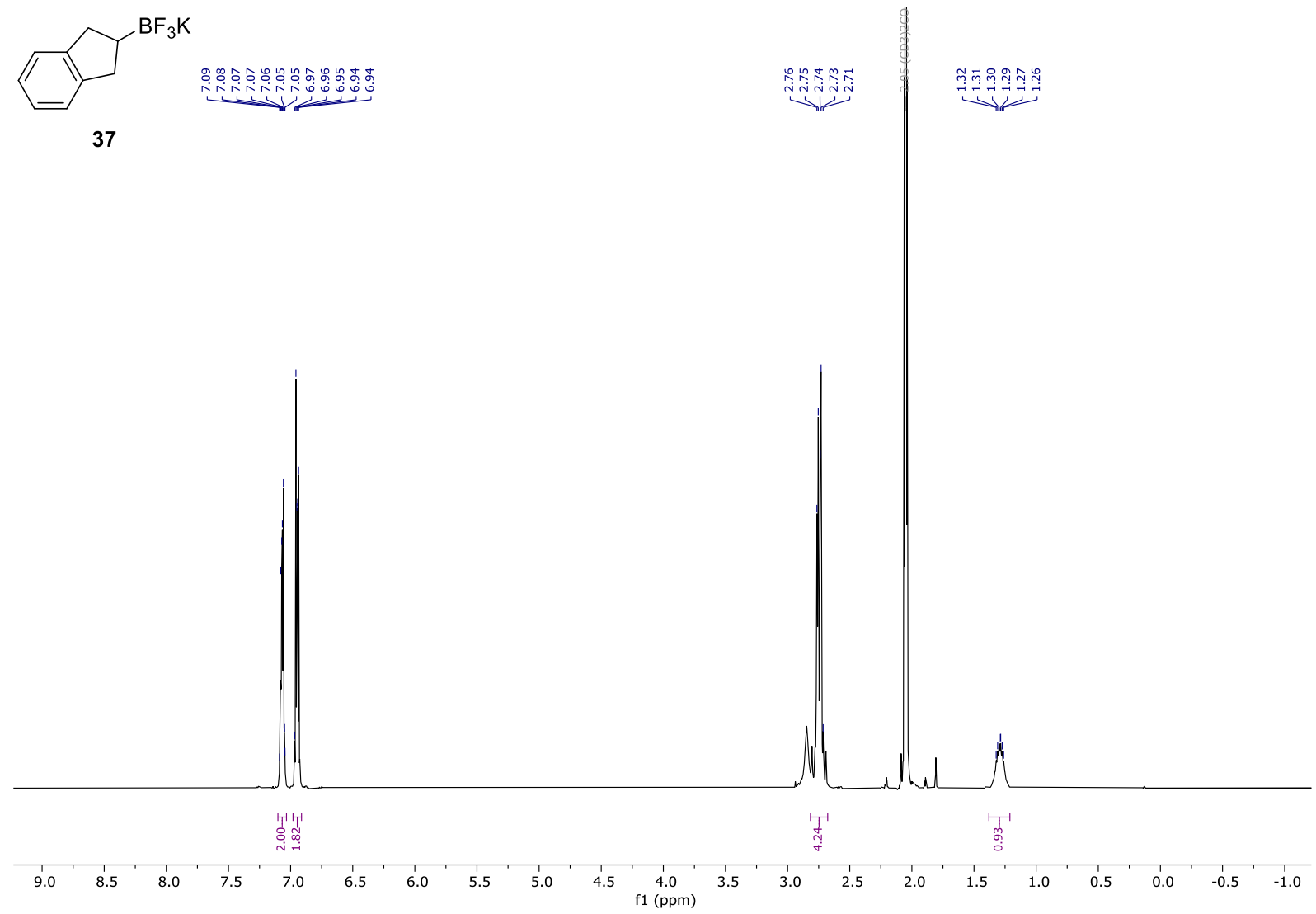

${ }^{13} \mathrm{C}$ NMR (101 MHz, acetone-d 6 ) of compound 37:

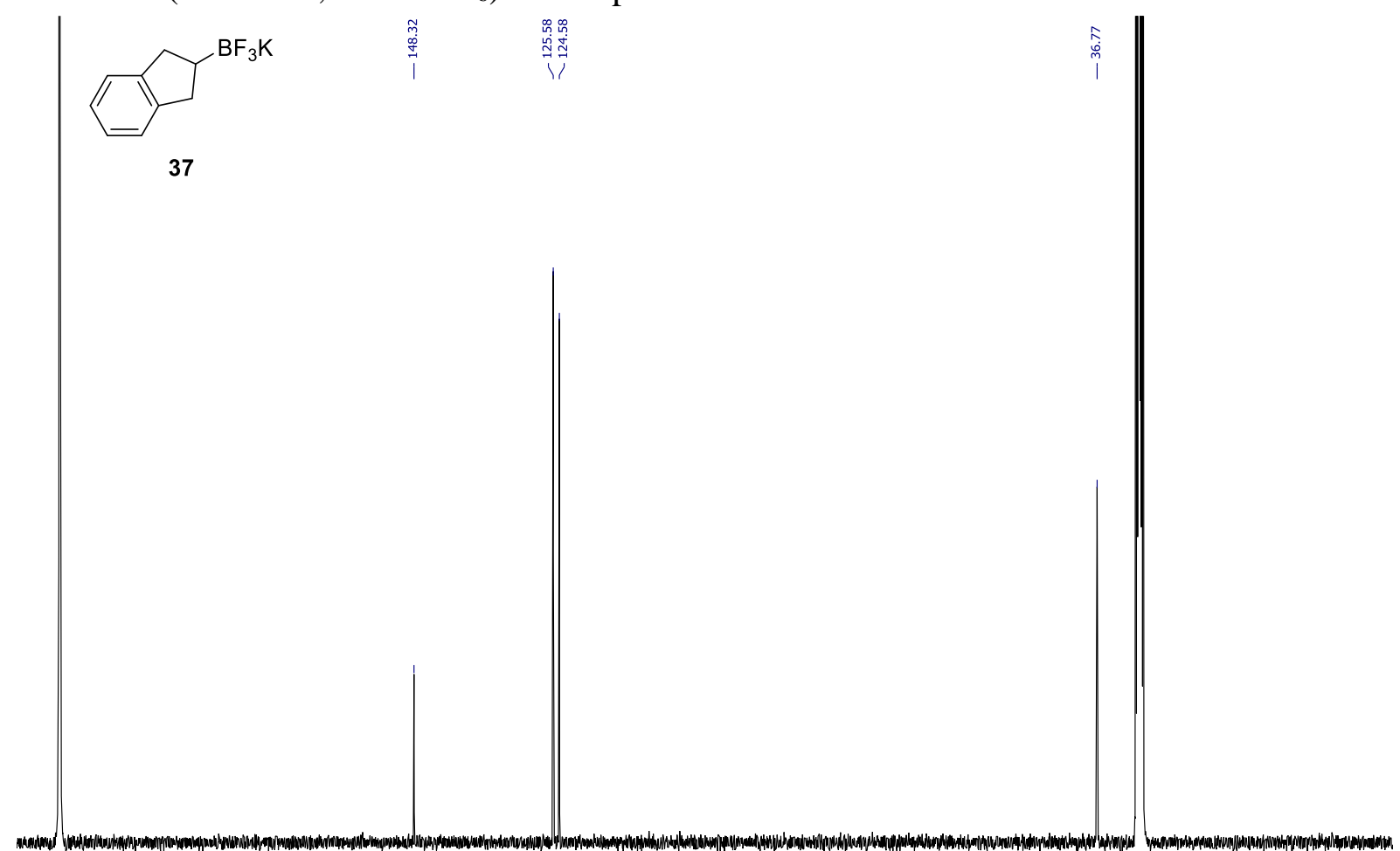

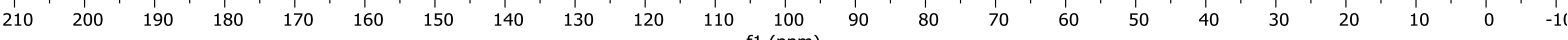


${ }^{19}$ F NMR (376 MHz, acetone- $\mathrm{d}_{6}$ ) of compound 37:

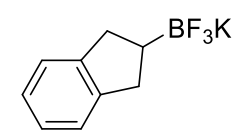

37

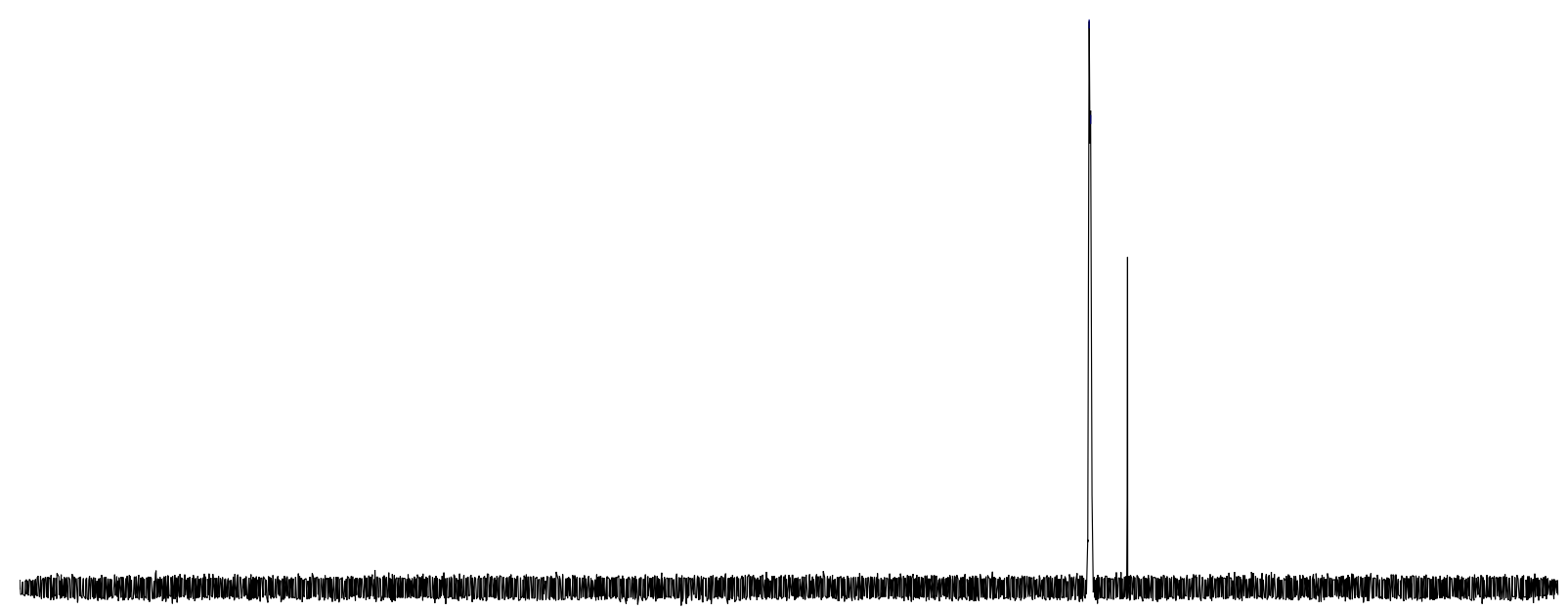

$\begin{array}{llllllllllllllllllllllllllllllll}10 & 0 & -10 & -20 & -30 & -40 & -50 & -60 & -70 & -80 & -90 & -100 & -110 & -120 & -130 & -140 & -150 & -160 & -170 & -180 & -190 & -200 & -210 & 1\end{array}$

${ }^{1} \mathrm{H}$ NMR (400 MHz, $\mathrm{CDCl}_{3}$ ) of compound 39:

$\mathrm{H}=$ TIPS

39
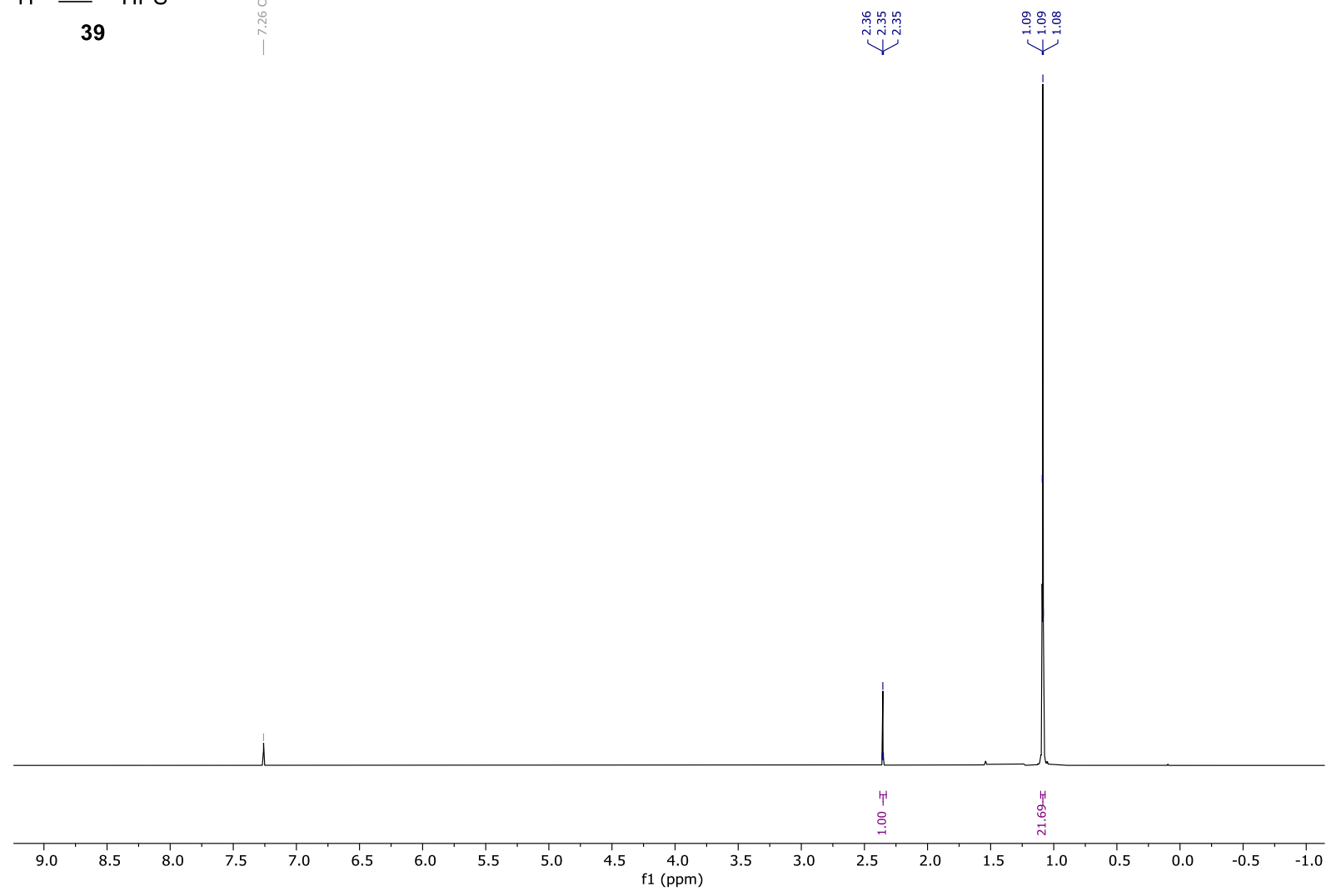
${ }^{13} \mathrm{C}$ NMR (101 MHz, $\mathrm{CDCl}_{3}$ ) of compound 39:

$\mathrm{H}-\frac{\overline{=}}{39}$ TIPS
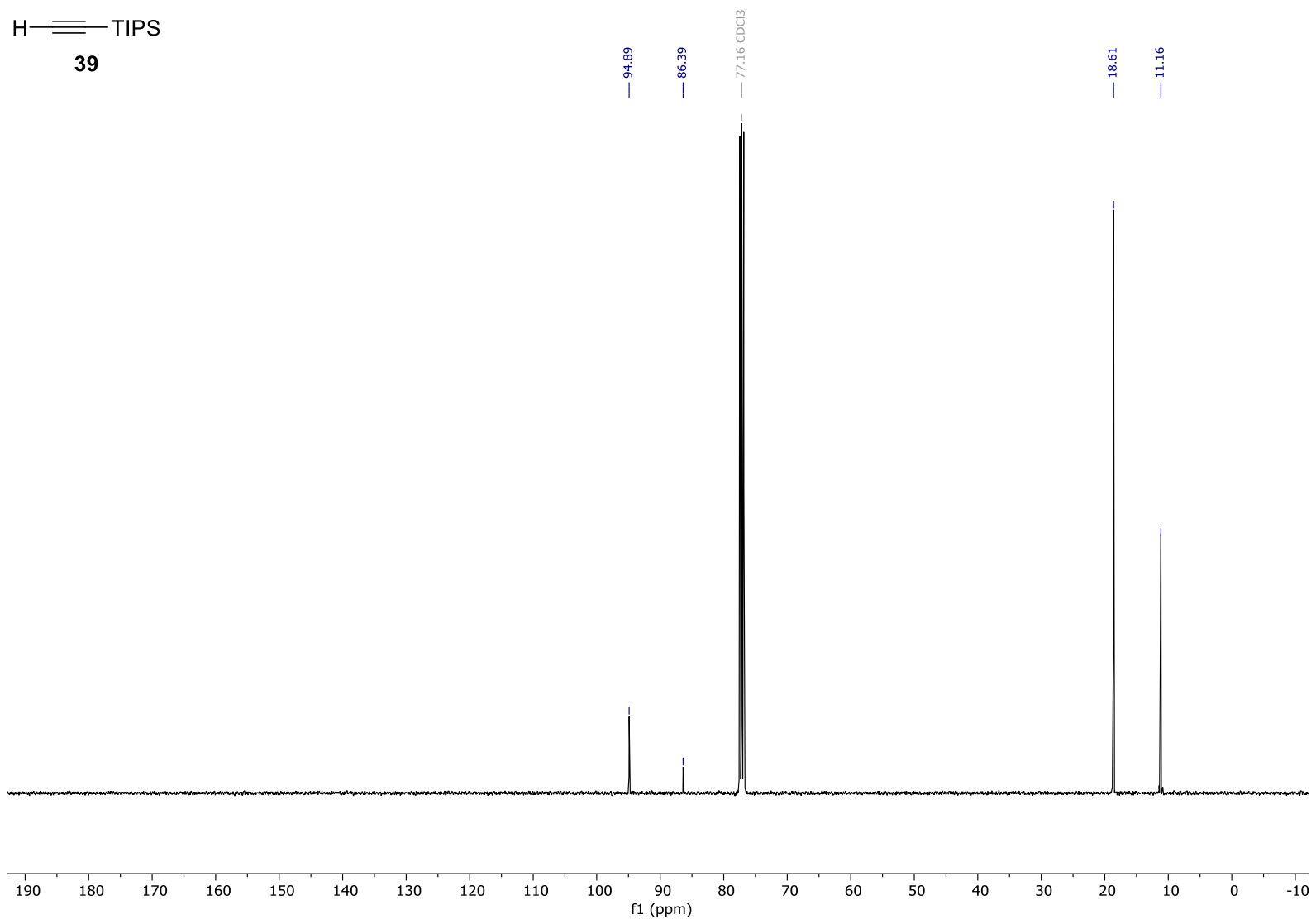

S111 